\title{
POWER SYSTEMS DEVELOPMENT FACILITY TOPICAL REPORT
}

\author{
GASIFICATION TEST CAMPAIGN TC14
}

FEBRUARY 16, 2004 - FEBRUARY 28, 2004

\section{DOE Cooperative Agreement \\ DE-FC21-90MC25140}

\author{
Prepared by: \\ Southern Company Services, Inc. \\ Power Systems Development Facility \\ P.O. Box 1069 \\ Wilsonville, AL 35186 \\ Phone: 205-670-5840 \\ Fax: 205-670-5843 \\ http://psdf.southernco.com
}

September 2007 


\section{DISCLAIMER}

This report was prepared as an account of work sponsored by an agency of the United States Government. Neither the United States Government nor any agency thereof, nor any of their employees, nor Southern Company Services, Inc., nor any of its employees, nor any of its subcontractors, nor any of its sponsors or cofunders, makes any warranty, expressed or implied, or assumes any legal liability or responsibility for the accuracy, completeness, or usefulness of any information, apparatus, product, or process disclosed, or represents that its use would not infringe privately owned rights. Reference herein to any specific commercial product, process, or service by trade name, trademark, manufacturer or otherwise, does not necessarily constitute or imply its endorsement, recommendation, or favoring by the United States Government or any agency thereof. The views and opinions of authors expressed herein do not necessarily state or reflect those of the United States Government or any agency thereof.

This report is available to the public from the National Technical Information Service, U.S. Department of Commerce, 5285 Port Royal Road, Springfield, VA 22161. Phone orders are accepted at (703) 487-4650. 


\begin{abstract}
In support of technology development to utilize coal for efficient, affordable, and environmentally clean power generation, the Power Systems Development Facility (PSDF) located in Wilsonville, Alabama, routinely demonstrates gasification technologies using various types of coals. The PSDF is an engineering scale demonstration of key features of advanced coal-fired power systems, including a KBR Transport Gasifier, a hot gas particulate control device (PCD), advanced syngas cleanup systems, and high pressure solids handling systems.

This report details test campaign TC14 of the PSDF gasification process. TC14 began on February 16, 2004, and lasted until February 28, 2004, accumulating 214 hours of operation using Powder River Basin (PRB) subbituminous coal. The gasifier operating temperatures varied from 1760 to $1810^{\circ} \mathrm{F}$ at pressures from 188 to 212 psig during steady air blown operations and approximately 160 psig during oxygen blown operations.
\end{abstract}




\section{ACKNOWLEDGEMENT}

The authors wish to acknowledge the contributions and support provided by various project managers: Elaine Everitt (DOE), Neville Holt (EPRI), Nicola Salazar (KBR), and Ben Wiant (Siemens). The project is sponsored by the U.S. Department of Energy National Energy Technology Laboratory under cooperative agreement DE-FC21-90MC25140. 


\section{TABLE OF CONTENTS}

Section Page

Inside Cover

Disclaimer

Abstract

Acknowledgement

List of Tables iii

List of Figures iv

1.0 EXECUTIVE SUMMARY ………………………………………………………..... 1.1-1

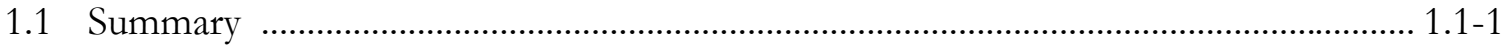

1.2 Test Campaign Objectives....................................................................................... 1.1-1

1.3 Test Campaign Summary ……………………………………………………..... 1.1-1

1.4 Test Campaign Performance ....................................................................................... 1.1-2

1.4.1 Transport Gasifier Performance ..................................................................... 1.1-2

1.4.2 Particulate Control Device (PCD) Performance .............................................. 1.1-3

1.4.3 Performance of Other Systems .....................................................................1-1-3

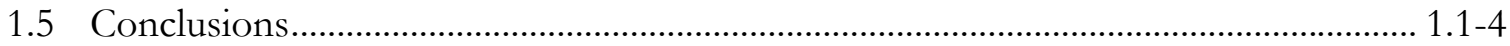

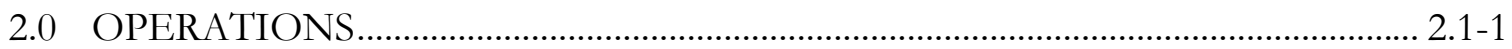

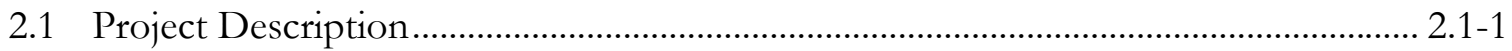

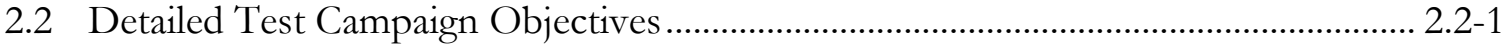

2.3 Detailed Test Campaign Summary ……………………………………………….... 2.3-1

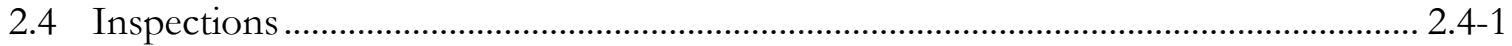

2.4.1 Transport Gasifier...................................................................................... 2.4 2.

2.4.2 Particulate Control Device .......................................................................... 2.4-2

2.4.3 Piloted Syngas Burner ......................................................................................... 2.4-3

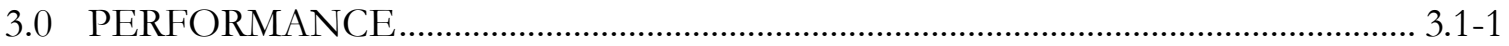

3.1 Transport Gasifier Performance.............................................................................. 3.1-1

3.1.1 Syngas Composition .................................................................................. 3.1-1

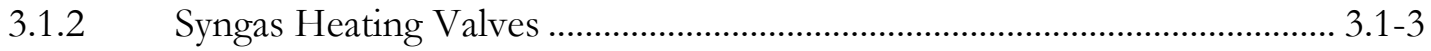

3.1.3 Gasifier Solids Analyses ........................................................................... 3.1-5

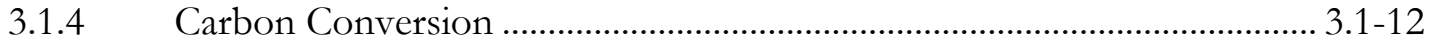

3.1.5 Gasification Efficiencies .......................................................................... 3.1-13 
3.2 Particulate Control Device Performance.......................................................................... 3.2-1

3.2.1 Particle Mass Concentrations .................................................................... 3.2-1

3.2.2 Real Time Particle Monitoring......................................................................... 3.2. 3.2

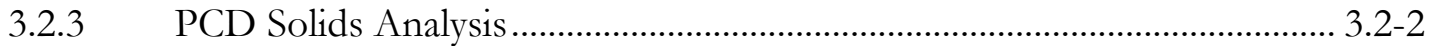

3.2.3.1 Particle Size Distributions.................................................................. 3.2-2

3.2.3.2 PCD Dust Cake Observations ........................................................ 3.2-3

3.2.3.3 Physical Properties and Chemical Compositions.......................... 3.2-3

3.2.3.4 Drag Measurements........................................................................ 3.2-6

3.2.4 PCD Pressure Drop ……………………………………………………… $3.2-7$

\section{APPENDICES}

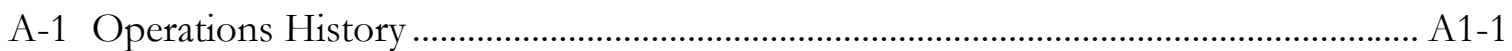

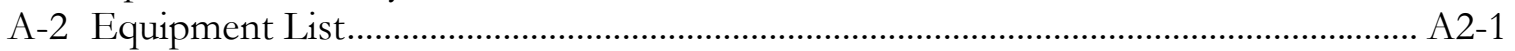

A-3 Mass and Energy Balances...................................................................................... A3-1

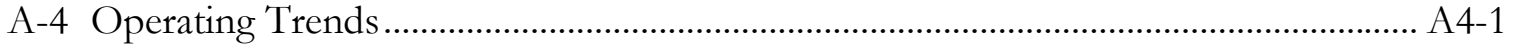

A-5 LHV Projection Calculations ……………………………………………………….. A5-1 


\section{LIST OF TABLES}

Table. Page

2.3-1 TC14 Operating Conditions for the Transport Gasifier and Particulate Control Device.....

3.1-1 Operating Periods

$3.1-2$ Operating Conditions

Gas Compositions, Molecular Weight, and Heating Value.

Projected Syngas Compositions, Molecular Weight, and Heating Value... 3.1-19

$3.1-6$

Coal Analysis

$3.1-7$

Standpipe Solids Analysis

$3.1-8$

Loop Seal Solids Analysis

$3.1-9$

PCD Solids from FD0520 and FD0540 Analysis

Historical As-Fed Coal Particle Sizes and Percent Fines and Oversize ..... 3.1-24

$3.1-11$

Historical Standpipe and PCD Fines

Carbon Conversion

PCD Inlet and Outlet Particulate Measurements for TC14

$3.2-2$

Residual Cake Measurements from TC14 and Previous Runs

Physical Properties of TC14 in Situ Samples and Hopper

Samples Used for RAPTOR

$3.2-4$

Chemical Composition of TC14 In Situ Samples and Hopper

Samples Used for RAPTOR 


\section{LIST OF FIGURES}

Figure Page

2.1-1 Flow Diagram of the Transport Gasifier Train......................................................... 2.1-3

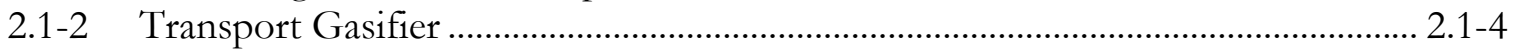

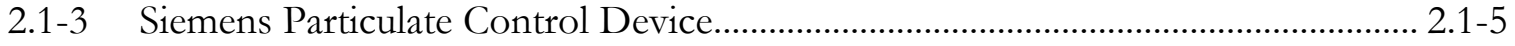

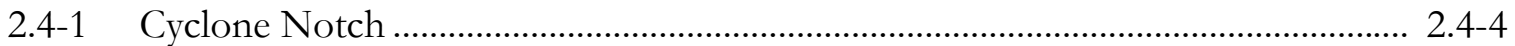

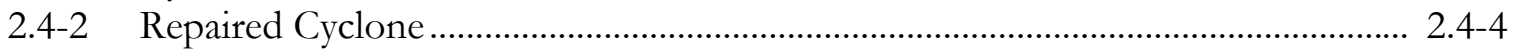

2.4-3 Piloted Syngas Burner (PSB) Nozzle Face........................................................... 2.4-5

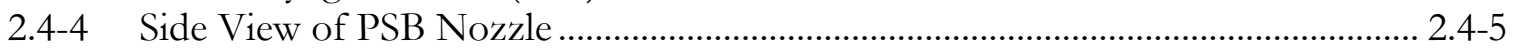

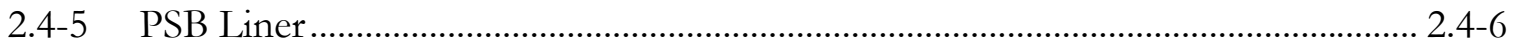

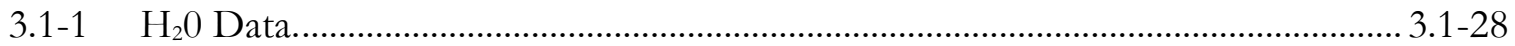

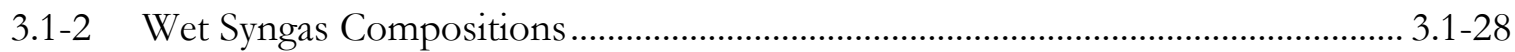

3.1-3 Syngas Molecular Weight \& Nitrogen Concentration............................................ 3.1-29

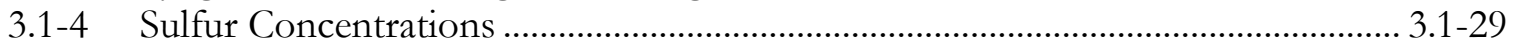

3.1-5 $\mathrm{H}_{2} \mathrm{~S}$ Analyzer AI419J \& Total Reduced Sulfur................................................... 3.1-30

3.1-6 Minimum Equilibrium H2S \& Total Reduced Sulfur .......................................... 3.1-30

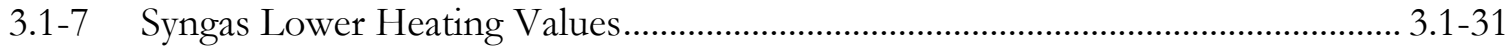

3.1-8 Raw Lower Heating Value \& Overall $\% \mathrm{O}_{2}$................................................................. 3.1-31

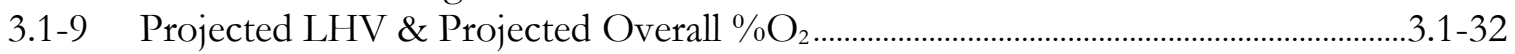

3.1-10 Coal Carbon \& Moisture.................................................................................................................

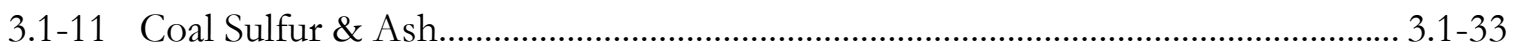

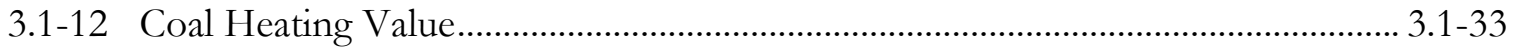

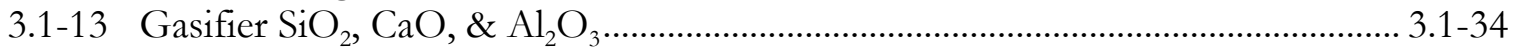

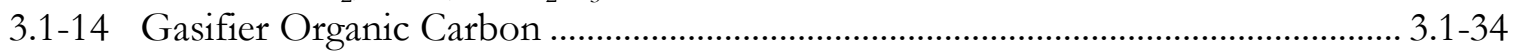

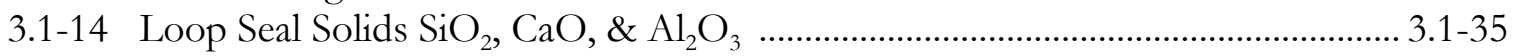

3.1-16 Loop Seal Solids Organic Carbon ......................................................................... 3.1-35

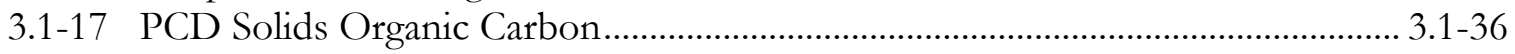

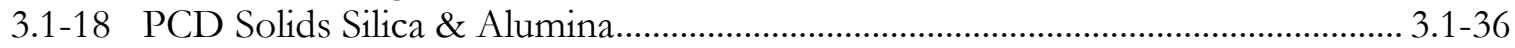

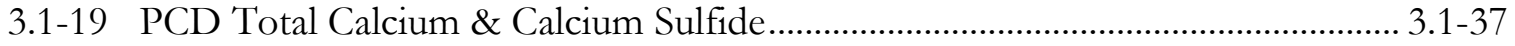

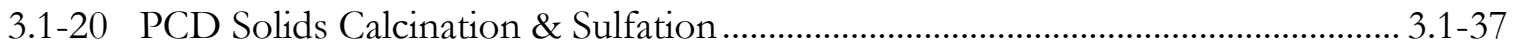

3.1-21 Standpipe, Loop Seal, and PCD Solids Organic Carbon Content ........................ 3.1-38

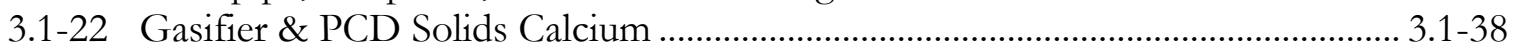

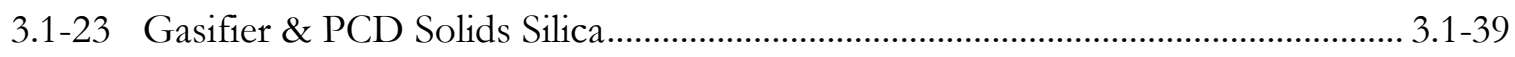

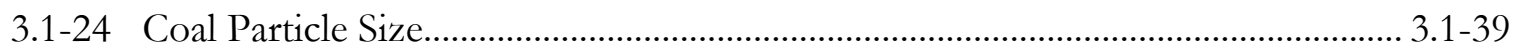

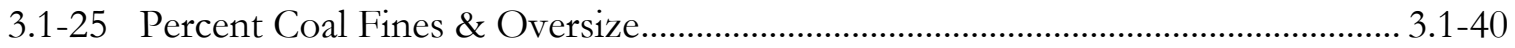

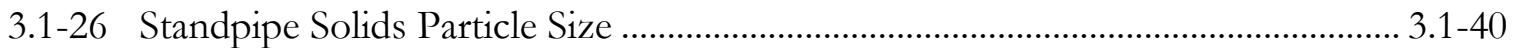

3.1-27 Standpipe Solids Fine and Coarse Particles ............................................................. 3.1-41

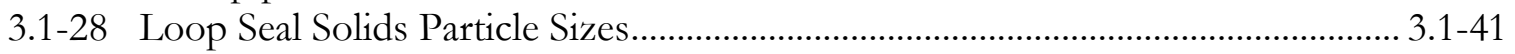

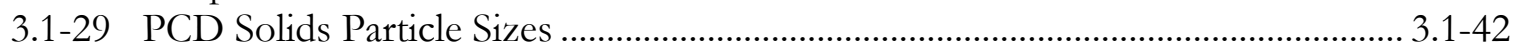

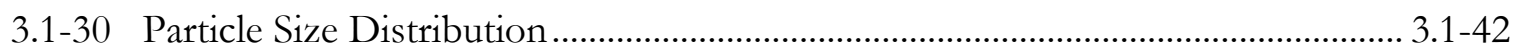

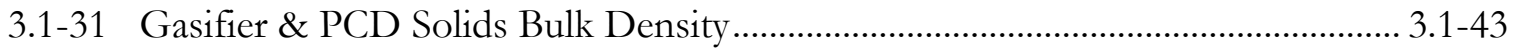

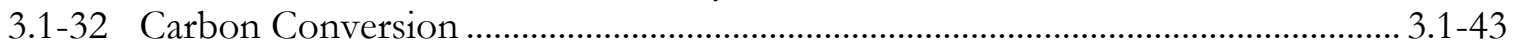

3.1-33 Carbon Conversion of Four Coals............................................................................. 3.1-44 


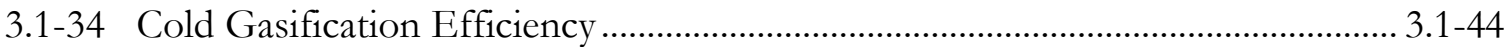

3.1-35 Cold Gasification Efficiency \& Steam to Coal Ratio ............................................... 3.1-45

3.1-36 Hot Gasification Efficiency …………................................................................. 3.1-45

3.2-1 PCD Inlet Particle of Concentration as a Function of Coal Feed Rate ................ 3.2-15

3.2-2 PCD Outlet Dust Concentrations for Recent Gasification Runs ..........................3.2-16

3.2-3 PCME Output during PCD Outlet Dust Injection Test .....................................3.2-17

3.2-4 PCME Output during CeraMem Failsafe Test ....................................................... 3.2-17

3.2-5 Relationship between PCME Output and Actual Particle Concentration............ 3.2-18

3.2-6 Micrograph of Sample Filter from PCME Injection Test ..................................... 3.2-19

3.2-7 Micrograph of Sample Filter from CeraMem Failsafe Injection Test.................... 3.2-19

3.2-8 Comparison of Average PCD Inlet Particle Size Distributions

On Mass Basis ........................................................................................................ 3.2-20

3.2-9 Comparison of Average PCD Inlet Particle Size Distributions

On Percentage Basis ........................................................................................ 3.2-21

3.2-10 Comparison of In Situ and Hopper Particle Size Distributions ............................ 3.2-22

3.2-11 Specific Surface Area versus Carbon Content of In Situ Samples ........................ 3.2-23

3.2-12 Laboratory Measurements of TC14 Dustcake Drag versus Particle Size............. 3.2-24

3.2-13 PCD Transient Drag Versus Carbon Content of In Situ Samples........................ 3.2-25

3.2-14 Comparison of PCD Transient Drag with Laboratory Measurements ................ 3.2-26

A1-1 Operating Hours Summary for the Transport Gasifier Train ............................ A1-4

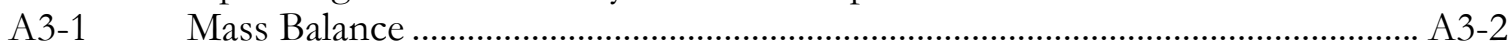

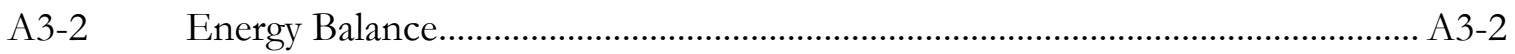

A4-1 Gasifier Mixing Zone, Riser, and Outlet Temperatures .................................... A4-1

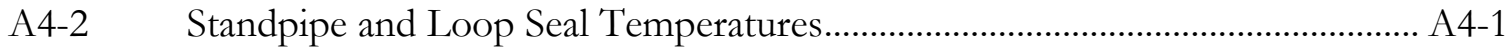

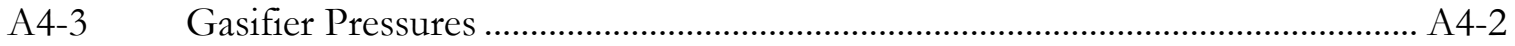

A4-4 Gasifier Differential Pressures.................................................................... A4-2

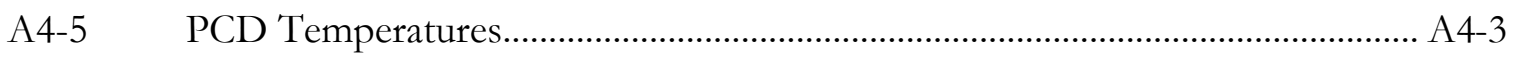

A4-6 PCD Baseline Pressure Drop and Face Velocity ................................................. A4-3

A4-7 System Temperature Profile................................................................................. A4-4

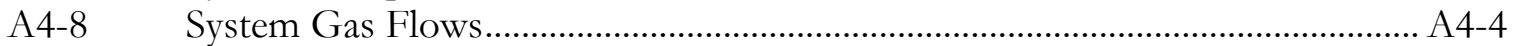

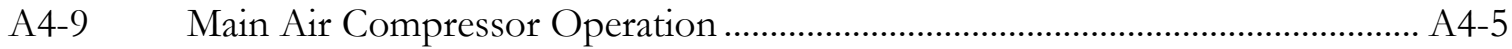

A4-10 Original Coal Feeder Operation .......................................................................... A4-5

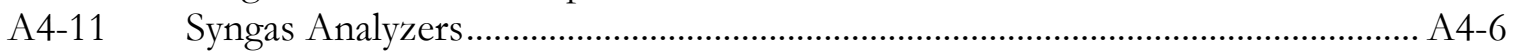

A4-12 Atmospheric Syngas Combustor Operation......................................................... A4-6 
POWER SYSTEMS DEVELOPMENT FACILITY

TEST CAMPAIGN TC14

CONTENTS

LIST OF FIGURES 


\subsection{EXECUTIVE SUMMARY}

\subsection{SUMMARY}

This report discusses test campaign TC14 of the PSDF gasification process at the Power Systems Development Facility (PSDF). The PSDF is a flexible test facility designed to develop advanced coal-fired power system components and assess the associated integration and control issues. The gasification process features a KBR (formerly Kellogg Brown \& Root) Transport Gasifier and a Siemens Power Generation (SPG) particulate control device (PCD), as well as high pressure solids handling systems and an advanced syngas cleanup slipstream system. TC14 began on February 16, 2004, and lasted until February 28, 2004, accumulating 214 hours of on-coal operation.

\subsection{TEST CAMPAIGN OBJECTIVES}

TC14 was an evaluation of gasifier and PCD operations with Powder River Basin (PRB) subbituminous coal using air and pure oxygen as the gasification oxidants. The primary test objectives were:

- Commissioning of the continuous fine ash depressurization (CFAD) system.

- Evaluating higher face velocity in the PCD.

- Testing the piloted syngas burner (PSB) and combustion turbine (CT) with syngas.

\subsection{TEST CAMPAIGN SUMMARY}

On February 16, initial startup began. After steady state conditions were reached, CFAD testing began mid-morning on February 20. The system ran well in batch mode. Automation work began the same day, consisting of several step change tests for measuring gasifier parameter responses.

The gasifier ran well during this time, but due to degraded cyclone performance, there was a continual loss of bed material and high solids carryover to the PCD. Even with the periodic addition of sand to the gasifier, the loss of bed material made it difficult to maintain adequate standpipe levels, causing lower circulation rates in the gasifier. Due to the lower circulation rate, the gasifier exit temperature was as much as $200^{\circ} \mathrm{F}$ below the mixing zone temperature.

On February 21, the fines removal lock hopper system stopped working when the Everlasting valve would not open due to gasification ash packing in the valve. For the remainder of the run, the CFAD system exclusively removed solids from the PCD. The CFAD system performed reliably, operating at discharge rates between 400 and 1,500 pph. 
The PSB and turbine were started on propane and tied to the electricity transmission grid at a load of around 1.0 MW on February 23. PSB testing using syngas continued throughout the week, combusting syngas at flow rates as high as 17,000 pph. Subsequent tests focused on reducing the assisting propane flow to a minimum. Altogether, the PSB achieved a total of 17 hours of operation on syngas during TC14.

The remainder of the air blown portion of the test run was relatively smooth, and parametric tests continued. The PCD operated reliably at the higher face velocity, maintaining a stable baseline pressure drop throughout the test campaign. The on-line testing of two types of failsafes was successfully completed during the run.

On February 27, a brief period of oxygen blown operation began to test the multi-parameter temperature controller and the newly installed standpipe aeration nozzles. The scheduled shutdown occurred on the evening of February 28. PCD backpulsing continued after coal feed ended to remove the transient dust the filter elements. During the test run, the gasifier accumulated 214 hours of coal feed, 21 of which were in oxygen blown mode.

\subsection{TEST CAMPAIGN PERFORMANCE}

Performance of the major equipment during TC14 is summarized below.

\section{$\underline{\text { 1.4.1 Transport Gasifier Performance }}$}

- During air blown gasification, the raw lower heating values at the exit of the gasifier were between 49 and $76 \mathrm{Btu} / \mathrm{SCF}$, resulting in projected heating values for a commercial gasifier of between 113 and $148 \mathrm{Btu} / \mathrm{SCF}$ at the gasifier exit. The projection translates the data received at the PSDF into commercial projections by taking into account the use of recycle gas and lower heat loss per pound of coal fed in a commercial gasifier. The heating values were slightly lower in TC14 than in previous test runs due to lower circulation rates caused by the degraded cyclone performance. The lower circulation rates limited the coal feed rate, which reduced the heating value.

- In oxygen blown gasification, the raw lower heating values at the exit of the gasifier ranged from 77 to $79 \mathrm{Btu} / \mathrm{SCF}$, resulting in projected heating values of 204 to 209 Btu/SCF.

- Most commercial gasifiers utilize cold gas cleanup technologies for sulfur and other contaminant removal, which requires the syngas to be cooled to nearly ambient temperatures. As the syngas is cooled, a significant amount of water is condensed out of the gas, increasing the syngas heating value. Based on data from this test campaign, the lower heating values at the gas turbine inlet ranged from 135 to 175 Btu/SCF for air blown operation and approximately 272 Btu/SCF for oxygen blown operation. 
- The carbon conversion was between 78 and 93 percent for both air and oxygen blown gasification. The TC14 carbon conversions were lower than usual due to the poor cyclone performance.

- The raw cold gasification efficiency ranged from 40.0 to 54.1 percent during air blown operations. It was 56.3 and 56.6 percent for the two oxygen blown operating periods. The commercially projected efficiency was between 58.0 and 72.6 percent for the air blown periods. The commercially projected efficiencies were 76.5 and 76.9percent based on the two oxygen blown operating periods.

- The hot gasification efficiency ranged from 71.1 to 83.4 percent for both the air and oxygen blown periods.

- The sulfur concentration of the syngas at the gasifier exit ranged from 144 to 314 ppm for air blown gasification and 318 to 350 for oxygen blown gasification. No limestone was fed into the gasifier during the test campaign.

- During air blown gasification, the ammonia concentration of the syngas at the gasifier exit ranged from 1,000 to $1,800 \mathrm{ppm}$. Ammonia concentrations were approximately $1,850 \mathrm{ppm}$ in oxygen blown gasification.

\subsubsection{PCD Performance}

- PCD operation was stable throughout the run. There were no filter element failures or gasification ash bridging.

- Outlet loading samples indicated good sealing of the filter vessel, with outlet loading maintained below the detection limit of 0.1 ppmw for most of the run.

- On-line failsafe testing with hot gasification ash injection was performed on both the Pall fuse and on the CeraMem ceramic failsafe. The Pall fuse plugged up quickly, and the outlet sampling performed just after injection showed a loading of less than 0.1 ppmw. The outlet loading at the beginning of injection to the CeraMem failsafe was about 3 ppmw, and it was less than 0.1 ppmw after 15 hours of injection.

\subsubsection{Performance of Other Systems}

- During a large portion of the air blown testing, a single parameter temperature controller maintained a steady temperature profile in the gasifier while controlling the air flow rate to the upper mixing zone and lower mixing zone. During oxygen blown testing, a new multi-parameter temperature controller maintained both the upper and lower mixing zone temperatures and gasifier exit temperature by adjusting the steam flow rate, oxygen flow rate, and coal feed rate. The controllers worked well for the majority of the run and provided useful data for future controls schemes.

- To further assess automation needs for the gasifier, several step change tests were performed. The tests consisted of planned variations in given process parameters while the gasifier was operating in steady state, and process responses to these changes were recorded and analyzed.

- The PSB achieved stable combustion using syngas with wet raw syngas heating values of 64 to $76 \mathrm{BTU} / \mathrm{SCF}$. As the propane flow rate decreased, the flame 
remained stable with as much as 82 percent of the total energy input to the gas turbine supplied by syngas.

- Efforts continued to find a measurement technique that would detect an unstable flame in the PSB. Neither the burner noise measurements nor the flame scanner signals proved to be reliable indications of unstable flames.

\section{5 CONCLUSIONS}

- The Transport Gasifier operated for 214 hours in TC14 using Powder River Basin (PRB) coal. Approximately 185 of the hours were in air blown gasification and the balance in oxygen blown gasification. Throughout the run, the gasifier lost approximately $100 \mathrm{pph}$ of bed material, requiring frequent replenishment of sand to maintain the standpipe level. This prevented the gasifier solids from reaching a steady state composition and increased the solids loading to the PCD, but the loss of solids did not interfere with the primary objectives for the test campaign.

- The CFAD system worked well, and operated as the primary fines removal system when the fines lock hopper Everlasting valve failed to operate. The CFAD concept proved to be sound and to be a viable alternative to using lock hoppers for pressurized solids removal. One operational issue with the CFAD system was that it removed solids at a higher rate than needed. For this reason, the CFAD system was primarily operated in a batch mode.

- At a higher than normal face velocity, the PCD operated stably throughout TC14. There were no filter element failures or gasification ash bridging.

- During TC14, the particle mass entering the PCD was higher than in previous PRB test programs, largely due to the performance problem with the gasifier solids collection system. The mass loading to the PCD increased. Although the mass loading was higher than usual, the relatively low normalized drag of the dust offset this negative effect. Compared to previous PRB gasification ashes, the TC14 gasification ash had an unusually coarse particle size distribution, high bulk density, low porosity, low surface area, and high concentration of inert meaterial. Because of these effects, the TC14 gasification ash was probably not representative of a "typical" PRB gasification ash.

- The PSB operated on syngas for 17 hours from February 23 through February 26. The maximum syngas flow rate was $17,000 \mathrm{pph}$, which was approximately 82 percent of the total energy input to the gas turbine (the balance was propane). 


\subsection{OPERATIONS}

\subsection{PROJECT DESCRIPTION}

The Power Systems Development Facility (PSDF), near Wilsonville, Alabama, is funded by the U.S. Department of Energy, Southern Company, and other industrial participants currently including the Electric Power Research Institute, KBR, Siemens Power, Peabody Energy, and the Lignite Energy Council. The PSDF is an engineering scale demonstration of key features of advanced coal-fired power systems designed at sufficient size to evaluate system components and assess the integration and control issues of these advanced power systems. The facility also supports clean coal technology programs to address environmental concerns associated with using fossil fuels for producing electricity, chemicals, and transportation fuels.

The KBR Transport Reactor which operates at the PSDF is a pressurized, advanced circulating fluidized bed reactor which can operate in either combustion or gasification mode. While operating in gasification mode, either air or oxygen can be used as the oxidant. The particulateladen gas exiting the reactor is filtered by a downstream high temperature, high pressure filter vessel, the Siemens particulate control device (PCD). In gasification mode, the objective of the PCD is to clean the gas sufficiently so that it can be utilized in a downstream gas turbine/combustor or fuel cell. A gas clean-up skid is also available to remove various pollutants from a syngas slipstream. A flow diagram of the gasifier train is shown Figure 2.1-1. The Transport Gasifier train has now operated for about 5,000 hours in combustion mode and over 5,000 hours during gasification.

The Transport Gasifier, shown in Figure 2.1-2, consists of a mixing zone, a riser, a disengager, a cyclone, a standpipe, a loopseal, and a J-leg. Steam and either air or oxygen are mixed together and introduced in the lower mixing zone while the fuel, sorbent, and additional air and steam (if needed) are added in the upper mixing zone. The steam and oxidant, along with the fuel, sorbent and solids from the standpipe, are mixed together in the upper mixing zone. The upper mixing zone, located below the riser, has a slightly larger diameter than the riser. The gas and solids move up the riser before entering the disengager, which removes larger particles by gravity separation. The majority of the solids flow from the disengager into the standpipe, and the remaining solids flow, along with the syngas, to the cyclone, which removes most of the particles not collected by the disengager. The solids collected by the disengager and cyclone are recycled back to the gasifier mixing zone through the standpipe and a J-leg. The nominal gasifier operating temperature is $1,800^{\circ} \mathrm{F}$, and the gasifier system is designed to have a maximum operating pressure of 294 psig with a thermal capacity of about $41 \mathrm{MBtu} / \mathrm{hr}$. Due to a lower oxygen supply pressure, the maximum operating pressure is about 180 psi during oxygen-blown gasification.

For start-up purposes, a direct propane-fired burner is provided at the gasifier mixing zone. Coal and sorbent (when required for sulfur capture) are separately fed into the Transport Gasifier through lockhoppers. Coal is ground to a nominal particle diameter between 250 and 400 microns. Sorbent, either limestone or dolomitic sorbent, is ground to a nominal particle diameter of 10 to 100 microns.

The gas exits the Transport Gasifier cyclone and goes to the primary gas cooler and then to the PCD for final particulate clean-up. The metal or ceramic filter elements used in the PCD remove 
almost all the dust from the gas stream. Shown in Figure 2.1-3, the PCD utilizes a tube sheet holding up to 91 filter elements, which are attached to one of two plenums. Process gas flows into the PCD through a tangential entrance, around a shroud, and through the filter elements into the plenums. Failsafe devices are located on the clean side of the filter elements to stop solids leakage in the event of element failures. High pressure nitrogen backpulsing, typically lasting 0.2 seconds, is used to clean the filters periodically to remove the accumulated solids and control the pressure drop across the tube sheet. The solids fall to the PCD cone and are removed through a lock hopper system or the continuous fine ash depressurization system (CFAD).

After exiting the PCD, a portion of the syngas can flow to the piloted syngas burner (PSB), where the gas is combusted using air from the turbine compressor. Propane supplied to the PSB serves as a pilot for the burner as well as a supplement to the syngas fuel to maintain burner flame stability. After combusting in the burner, the gas passes through the turbine before exiting the turbine stack. An associated generator supplies power to the electricity transmission grid. The PSB and turbine system are capable of running independently of the gasifier by using propane alone as fuel. A small portion of the syngas can also flow to a specialized gas cleanup system downstream of the PCD. The gas cleanup system removes sulfur, nitrogen, and chlorine compounds, providing a syngas suitable for use in a fuel cell.

The syngas not flowing to the PSB or cleanup system continues to the secondary gas cooler and then passes through a pressure control valve. The gas is then sent to the atmospheric syngas combustor (thermal oxidizer) which oxidizes carbon monoxide, reduced sulfur compounds $\left(\mathrm{H}_{2} \mathrm{~S}\right.$, $\mathrm{COS}$, and $\left.\mathrm{CS}_{2}\right)$, and reduced nitrogen compounds $\left(\mathrm{NH}_{3}\right.$ and $\left.\mathrm{HCN}\right)$. The atmospheric syngas combustor uses propane as a supplemental fuel. The gas from the atmospheric syngas combustor goes to the heat recovery boiler, through the baghouse, and then to the stack.

The Transport Gasifier produces both fine solids filtered by the PCD and coarse solids extracted from the gasifier standpipe. The two solid streams are cooled using screw coolers, reduced in pressure in lock hoppers and then combined together. The CFAD system is also available for removing fine solids from the PCD. 


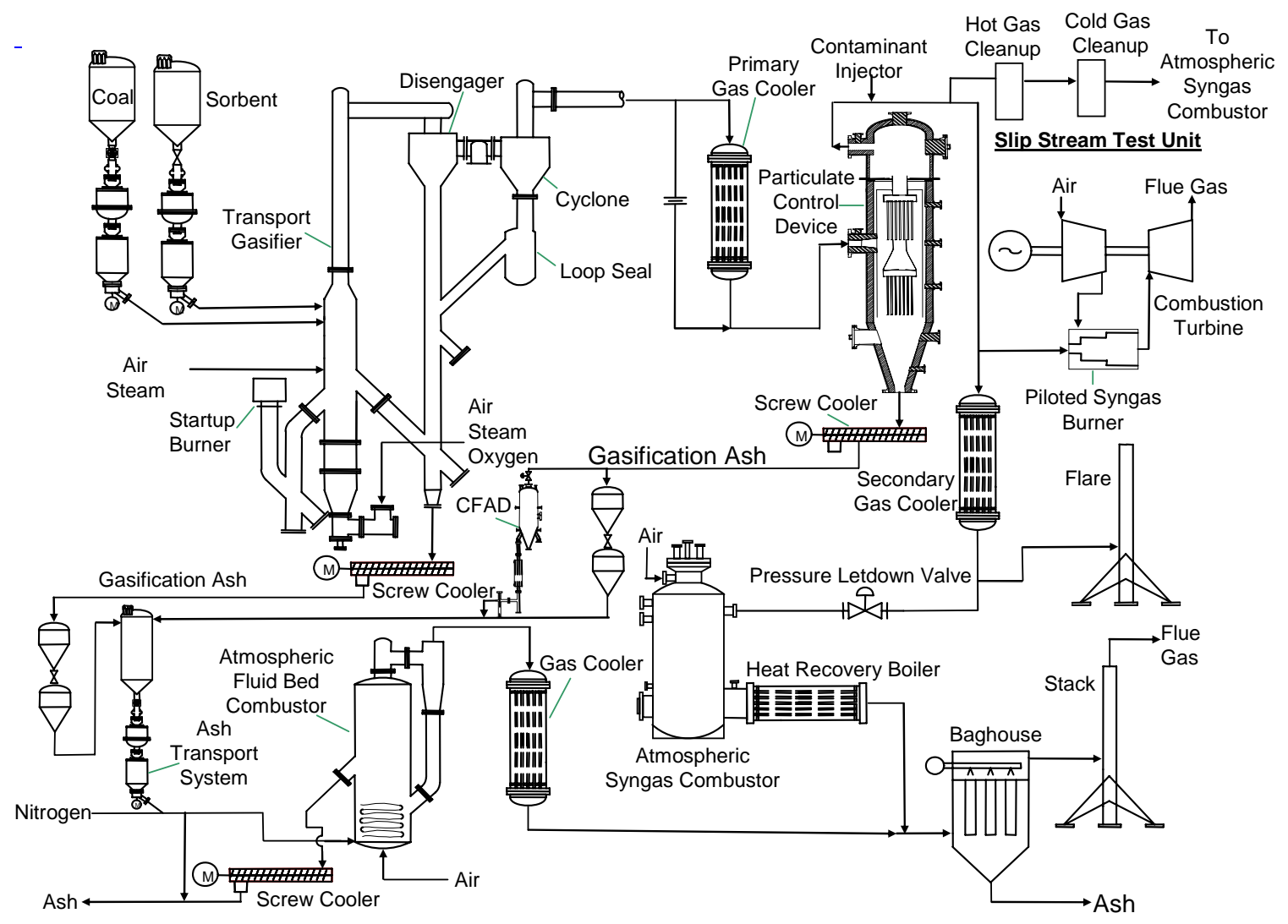

Figure 2.1-1. Flow Diagram of the PSDF Gasification Process 


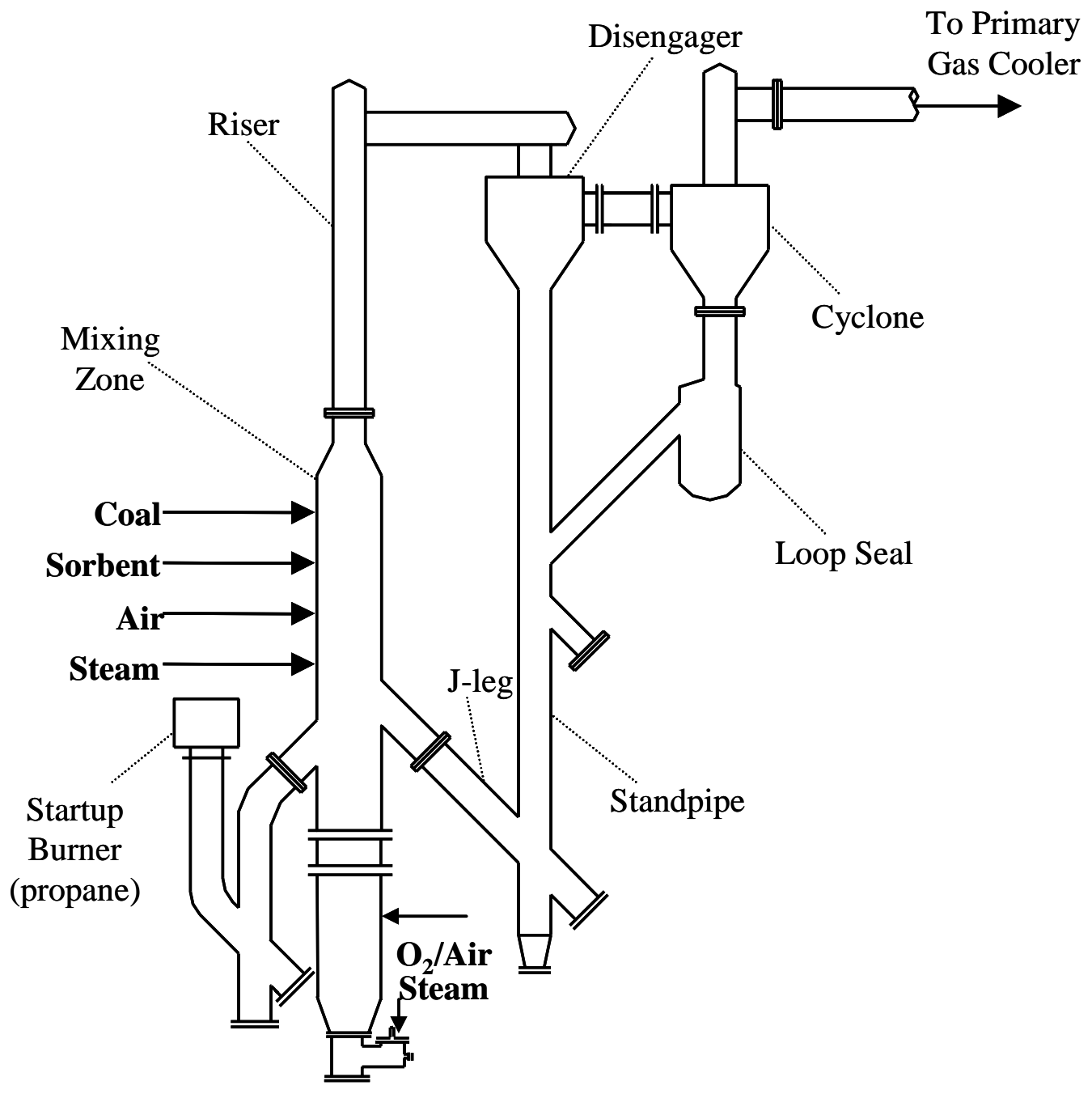

Figure 2.1-2. KBR Transport Gasifier 


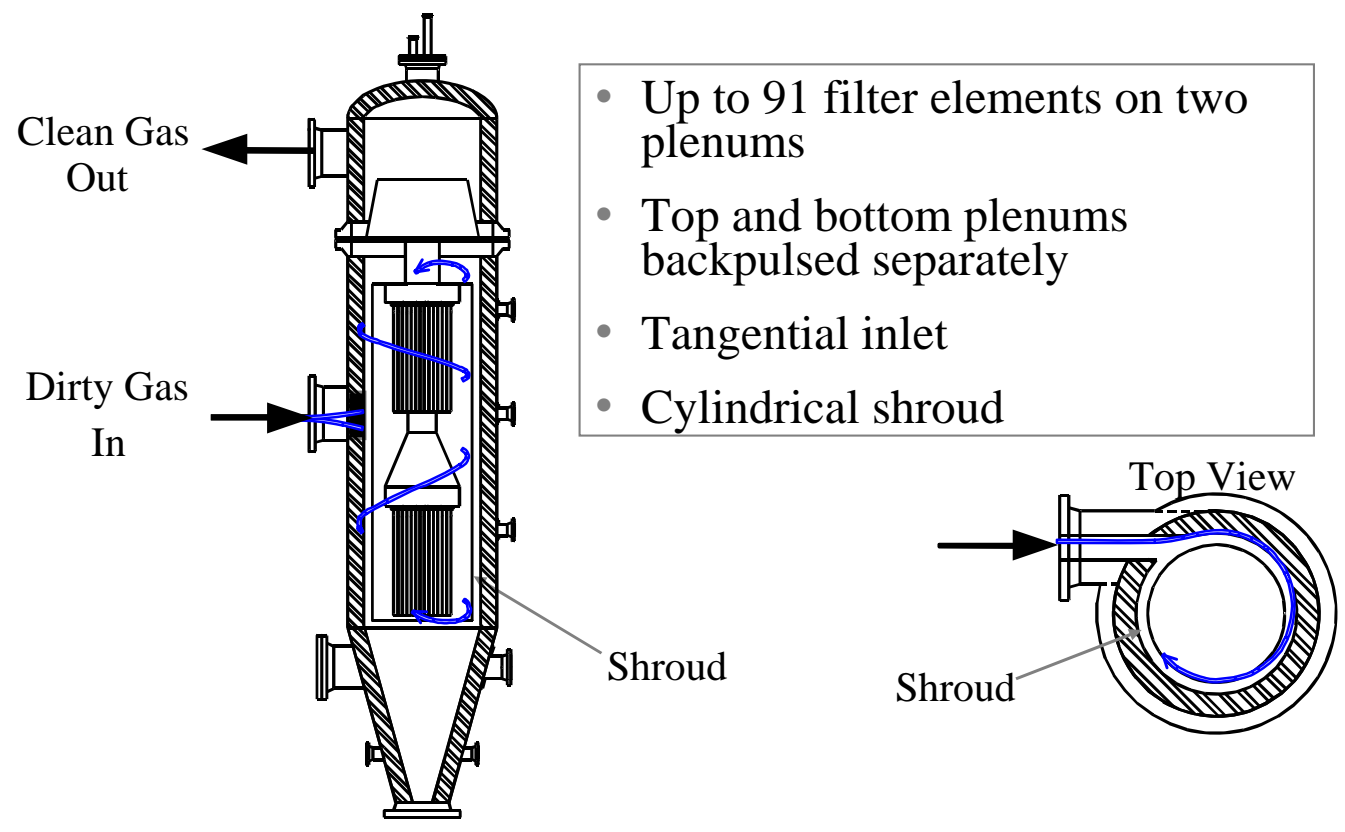

Figure 2.1-3. Siemens Particulate Control Device 


\subsection{DETAILED TEST CAMPAIGN OBJECTIVES}

TC14 was planned as a nominally 250-hour test run to evaluate gasifier and PCD operations using Powder River Basin (PRB) subbituminous coal. The primary test campaign objectives were:

- Commissioning of continuous fine ash depressurization (CFAD) system - The functionality of the CFAD system was tested while commissioning the system with sand and later operating it with spent solids from the PCD. The system was used as the primary PCD solids removal method during most of the run.

- Evaluating higher face velocity in the PCD - The effects of reduced surface area and higher face velocity on PCD performance were evaluated. For TC14, the number of filter elements was reduced from a maximum of 91 to 72 by removing the center portion of the lower plenum elements.

- Testing the piloted syngas burner (PSB) and combustion turbine (CT) with syngas - The operation of the PSB and turbine on syngas was evaluated with regards to temperature profile, flame stability, burner pressure dynamics, emissions, and operations with low augmenting fuel flow.

Secondary objectives included the following:

- Effect of moisture on the coal feed system - In an effort to improve coal feeder performance, modifications of the coal grinding process were implemented to reduce the moisture content of the coal. The effect of reduced coal moisture on the feed system operations was evaluated.

- Automation development-The automatic control of the gasifier was demonstrated and improved, including the single-parameter temperature controller in air blown mode which controlled gasifier temperature by adjusting air flow rates, and the multi-parameter temperature controller in oxygen blown mode which maintained temperature set points by adjusting oxygen, steam, and coal feed rates.

- Process Performance - Efforts continued to evaluate the effects of different gasifier parameters such as the steam-to-coal ratio and CO-to- $\mathrm{CO}_{2}$ ratio on carbon conversion, and product gas composition.

- Sensor development - To improve gasifier instrument longevity, the study of various materials of construction and installation methods of thermowells and pressure differential instruments continued. The evaluation of nuclear density solids flow instrumentation was also continued.

- Standpipe operations - The use of additional aeration in the lower standpipe was evaluated to improve operational stability of the standpipe.

- Failsafe testing - On-line testing of the CeraMem failsafe and Pall fuse was completed using the hot gasification ash injection tester. The failsafe tester allowed unfiltered syngas to be directly injected into the clean side of the filter element and upstream of the failsafe to simulate an element failure. Failsafe performance was evaluated by outlet particulate sampling. 


\subsection{TEST CAMPAIGN SUMMARY}

The activities that occurred during the outage preceding test run TC14 included 34 equipment modifications. The most significant of these are listed below:

- A new Continuous Fine Ash Depressurization system (CFAD) was installed in parallel to the fines removal lock hopper system for removing fine solids from the PCD. The CFAD proved to be a viable alternative to the lock hopper system.

- A new plate in the FD0210 coal feeder was installed for better control of the coal feed rate.

- Significant enhancements to the multi-parameter temperature controller and the single parameter temperature controller were implemented for more reliable automatic control of the gasifier temperatures.

- Two additional standpipe aeration nozzles were added to improve solids circulation by providing smoother downward flow of solids in the standpipe and preventing gasifier upsets.

The following is a brief operating synopsis of TC14 from February 16, 2004, through February 28, 2004:

February 16

Once the PCD preheat was complete, the startup burner was lit to heat the gasifier to a temperature suitable for coal feed.

February 17

Once the gasifier temperature reached $1100^{\circ} \mathrm{F}$, coal feed began. Initially, coal feed was maintained at a low rate to allow operation with excess oxygen (in combustion mode) so that the gasifier temperature could be quickly increased without tar formation.

When the gasifier was about $1500^{\circ} \mathrm{F}$, a standpipe upset caused a loss of circulation, sending a large amount of material to the PCD and tripping the coal feeder. The large carryover of solids exacerbated problems with the fines removal lock hopper system Everlasting valve operation. Before coal feed could resume, the fine solids screw cooler developed a leak. A system shutdown was necessary to repair the screw cooler.

February 18

Once the leak on the screw cooler was repaired, the test run proceeded with the re-lighting of the startup burner.

February 19

By the evening the gasifier temperature reached $1100^{\circ} \mathrm{F}$, and coal feed resumed. A gasifier upset occurred, and the PCD filter element thermocouples indicated temperatures as high as $1345^{\circ} \mathrm{F}$, 
although apparently no damage to the elements occurred. There were no significant temperature spikes on the PCD filter elements for the remainder of the run.

February 20

Coal feed once again ended when packing formed in the gasifier standpipe, stopping circulation and tripping the coal feeder. The standpipe aeration nozzles removed the packing, and coal feed resumed at just past midnight.

CFAD testing began during the morning. The system ran well in a batch mode, but it did not run continuously because the discharge rate was higher than the inlet solids rate.

Automation work began, which consisted of several step change tests for measuring gasifier parameter responses.

The gasifier ran well, but bed material loss continued. Poor cyclone efficiency resulted in low solids collection efficiency and a high solids carryover rate to the PCD. Due to the excessive sand loss, the sand feeder had to supply sand to the gasifier on an almost continuous basis. Temperatures in the gasifier were steady, with the highest temperatures ranging between $1,790^{\circ} \mathrm{F}$ and $1,825^{\circ} \mathrm{F}$. The coal feed rate was around 3,000 pph, and the gasifier pressure was 188 psig.

Over the next several days, the highest gasifier temperature was automatically controlled at around $1810^{\circ} \mathrm{F}$ by controlling the lower mixing zone (LMZ) and upper mixing zone (UMZ) air flow rates. However, due to the low circulation rate caused by the loss of bed material from the gasifier, the gasifier exit temperature was often $200^{\circ} \mathrm{F}$ below the mixing zone temperature.

February 21

During the evening, the fines removal lock hopper system was removed from service when the Everlasting valve failed to open. The malfunction required the CFAD to be the primary means of fines removal for the remainder of the test run. The CFAD performed very well, at discharge rate varying between 400 and $1500 \mathrm{pph}$, but ran best at the higher flow rates.

February 22

The gasifier continued to run well, despite two short trips that occurred due to a nitrogen shortage. Once the system was stable again, the preheat sequence for the syngas line to the PSB began, and the coal feed rate was increased to improve the syngas heating value.

February 23

The PSB and turbine were started on propane and tied to the electric transmission grid at a load of around 1.0 MW. The first time syngas entered the PSB, the turbine tripped when a large burst of syngas and nitrogen blew out the flame. On the second attempt, the syngas flow rate was lower, and the PSB ran steadily for two hours. A thermocouple in the PSB later failed and tripped the system. 
PSB testing using syngas continued throughout the week, achieving syngas flow rates up to 17,000 pph. Subsequent testing focused on minimizing the flow of propane added to the PSB to support combustion. When the propane flow was reduced, a high temperature on the propane nozzle tripped the CT. By adding a nitrogen purge flow to the nozzle, the PSB was able to run with 82 percent of the total energy coming from syngas.

Following the few PSB trips, transition of the syngas flow to the flare was smooth, and the gasifier pressure was affected by less than 2 psig, causing no problems with system operation. The PSB achieved a total of 17 hours of syngas flow during TC14.

February 25

A short trip occurred when one of the mixing zone temperatures went above the trip setpoint.

February 26

Two more coal brief feeder trips occurred due to nitrogen shortages. After the trips, parametric tests continued.

February 27

The transition to oxygen blown operations began, with the gasifier operating at a pressure of 160 psig. Later in the day, the multi-parameter temperature controller was tested maintaining the maximum gasifier temperature around $1,815^{\circ} \mathrm{F}$.

The loss of bed material from the gasifier decreased due to lower riser velocities. The circulation rate was still low, however, and air flow through the upper mixing zone air nozzles was required at times to maintain a gasifier exit temperature around $1,650^{\circ} \mathrm{F}$.

Failsafe testing on the Pall fuse and the CeraMem failsafe was begun and continued through the next day.

February 28

The system was shut down. PCD backpulsing continued throughout the shutdown to remove the transient dust cake from the filter elements.

Typical operating conditions for both the Transport Gasifier and the PCD are shown in Table 2.3-1. 
Table 2.3-1

TC14 Operating Conditions for Transport Gasifier and Particulate Collection Device

\begin{tabular}{|l|l|}
\hline \multicolumn{2}{|c|}{ Transport Gasifier } \\
\hline Startup Bed Material & Sand, $\sim 120$ micron \\
\hline Startup Fuel & Coal \\
\hline Fuel Type & Powder River Basin \\
\hline Fuel Particle Size (mmd), micron & $330-600$ \\
\hline Average Fuel Feed Rate, pph & $2,900 \cdot 4,400$ \\
\hline Sorbent Type & None \\
\hline Gasifier Temperature, ${ }^{\circ} \mathrm{F}$ & $1760-1810$ \\
\hline Mixing Zone Pressure, psig & $160\left(0_{2}\right), 188-212$ (air) \\
\hline Riser Gas Velocity, fps & $32 \cdot 50$ \\
\hline Standpipe Level, inH ${ }_{2} 0$ & $26-65$ \\
\hline Total Gas Flow Rate, $\mathrm{pph}$ & $13,000 \cdot 21,000$ \\
\hline Oxygen/coal mass ratio, lb/lb & $0.6 \cdot 1.0$ \\
\hline Oxygen/steam mass ratio, lb/lb & 0.8 \\
\hline Steam/coal mass ratio, lb/b & $0.2 \cdot 0.7$ \\
\hline
\end{tabular}

\begin{tabular}{|l|l|}
\hline \multicolumn{2}{|c|}{ Particulate Control Device } \\
\hline PCD Temperature, ${ }^{\circ} \mathrm{F}$ & $700 \cdot 825$ \\
\hline PCD Inlet Loading, ppmw & $22,600 \cdot 44,000$ \\
\hline PCD Outlet Loading, ppmw & $<1$ \\
\hline PCD Pressure Drop, inH 20 & $60 \cdot 100$ \\
\hline Number of Filter Elements & 72 \\
\hline Filtration Area, $\mathrm{ft}^{2}$ & 204.3 \\
\hline Face Velocity, $\mathrm{ft} / \mathrm{min}$ & $3.0 \cdot 4.0$ \\
\hline Pulse Valve Open Time, sec & 0.2 \\
\hline Pulse Time Trigger, min & $7 \cdot 10$ \\
\hline Pulse Pressure, Top Plenum & $320 \mathrm{psi}$ above System Pressure \\
\hline Pulse Pressure, Bottom Plenum & $400 \mathrm{psi}$ above System Pressure \\
\hline
\end{tabular}


POWER SYSTEMS DEVELOPMENT FACILITY

TEST CAMPAIGN TC14
OPERATIONS

TEST CAMPAIGN SUMMARY 


\subsection{INSPECTIONS}

\subsubsection{Transport Gasifier}

With the exception of the high carryover of solids from the gasifier to the PCD, the Transport Gasifier performed well throughout the test campaign. There were very few deposits found anywhere in the gasifier loop. However, the focus of the gasifier inspection was on the erosion that had occurred in the cyclone barrel. The notch that eroded in the barrel was repaired during the outage.

Both the mixing zone and the riser were relatively clean. There were a few deposits in the mixing zone, but these were similar to deposits that have been seen in the past. Both the riser and secondary crossovers had minor soft deposits.

The disengager was in good condition, and there was very little change in its appearance between this run and the previous run. However, the cyclone had several deposits. A notch had eroded in the wall, and there were deep cracks in the refractory as shown in Figure 2.4-1. The inlet to the cyclone was not perfectly tangential to the cyclone barrel. Therefore, a notch was eroded in the wall of the cyclone at the point where solids in the inlet would impact the wall. This disrupted the flow of gas and solids in the cyclone and contributed to the deposits on the wall.

Initially, it was decided to repair the notch by grinding out the refractory, making the inlet tangential, and eliminating the notch. Unfortunately, this proved to be very difficult and it was decided to remove the refractory in this area and re-cast it. When the refractory was removed, a deep crack was discovered near the cyclone inlet in an area that was not being repaired. This discovery necessitated the removal of the rest of the hard faced refractory in the wall of the cyclone. The refractory was successfully re-cast as shown in Figure 2.4-2.

The roof of the cyclone also had extensive damage. It was bowed and the refractory was badly cracked. It was temporarily repaired and will be replaced prior to TC16.

The standpipe was clean and the screw flights on FD0206 were visible. The loop seal had a number of small deposits on the walls of the downcomer. The bottom of the loop seal had several loose deposits that appeared to have fallen off the wall of the downcomer.

The startup burner J-leg had a number of agglomerations. These were hard but loose, indicating that they may have formed elsewhere in the gasifier and accumulated in the J-leg. These agglomerations were easily drained.

The primary gas cooler inlet was fairly clean and it was unnecessary to replace any of the ferrules. There was very little tar in the cone of the secondary gas cooler. 


\subsubsection{Particulate Control Device}

After the test run, the PCD internals were removed from the filter vessel and inspected. The outage inspection included examinations of the filter elements, their fixtures to the plenums, solids deposition, filter element gaskets, and auxiliary equipment.

For TC14, the following filter elements were installed: twenty-one Pall 1.5 meter iron aluminide (FEAL) filter elements with fuses, forty-nine Pall 1.5 FEAL filter elements without fuses, and two Pall Hastelloy X filter elements. A total of five Pall FEAL filter elements were removed for inspection. Each filter was closely inspected and no damage was noted. The welds were examined and no separation from the filter media or cracks was noticed.

All the FEAL filter elements removed were flow tested using air at ambient temperature. The flow test results revealed that at a face velocity of $3 \mathrm{ft} / \mathrm{min}$, the pressure measured on elements ranged from 25 to $28 \mathrm{inH}_{2} \mathrm{O}$. These values are similar to those measured after previous gasification runs. Each of the new Hastelloy X filter elements was removed during the outage for inspection. The filter integrity appeared to be in good condition. The welds were inspected, and there was no sign of separation from the filter media. However, when flow tested, both filter elements had excessively high pressure drops. Figure 2.4-4 shows the results of the Hastelloy X material flow test. The flow test results revealed that at a face velocity of $3 \mathrm{ft} / \mathrm{min}$, the pressure drop measured on the P050 was $\sim 48 \mathrm{inH}_{2} \mathrm{O}$, while the pressure drop for the $\mathrm{P} 090$ filter element was $\sim 32 \mathrm{inH}_{2} \mathrm{O}$.

Three Pall fuses and Pall four Siemens ceramic failsafes were removed and inspected. Four second generation CeraMem ceramic failsafe devices were removed. Each failsafe was visually inspected and flow tested. No damage was noted on any of the failsafes during the inspection. These failsafe devices have accumulated over 700 on-coal hours of exposure since they were first installed in TC13.

The collection efficiency of one of the three Pall fuses removed was tested during TC14 by solids injection. This particular Pall fuse appeared to be in good condition structurally. The other two Pall fuses that were removed were inspected as well and flow tested. The flow test results did not show any signs of pore blinding due to corrosion or solids penetration and the flow coefficient for this Pall fuse was 88 percent of the measured virgin value.

During TC14, seven prototype inverted candle assemblies supplied by SWPC were installed in the PCD and tested. The inspection after TC14 did not reveal any signs of bridging within the filter elements. Therefore, further testing will continue during TC15.

The back pulse pipes were removed and inspected during this outage. There was no significant damage noted on either the pulse pipes or the inner liner. The pulse pipes have now been exposed to over 5000 hours on on-coal gasification operation without any significant corrosion. 


\subsubsection{Piloted Syngas Burner}

The syngas nozzle was removed for inspection after testing was completed. The equipment all appeared to be in good shape with no sign of overheating or other damage. There were significant soot deposits on the nozzle, both on the face and extending back upstream through the air inlet windows. The liner was also discolored down to the end of the primary air scoops. The soot deposits were not heavy enough to affect operation, but were much heavier than seen after previous tests. The syngas nozzle face is shown in Figure 2.4-3. Note that there is no soot deposit on the area between the inner row of syngas holes and the propane holes. This is also the area that tended to overheat during the syngas tests. Figure 2.4-4 shows a side view of the nozzle. Soot deposits extended back through the air inlet windows and there was also soot on the liner neck. Apparently pressure swings allowed the soot to work its way upstream against the air flow. The metal upstream from the nozzle face was not discolored and there was no indication that this area had been hot. Figure 2.4-5 is a photo of the liner taken through the neck. The discoloration extends down to the point where the primary air is added, indicating that the discoloration is related to the relatively rich operation in the upstream end of the burner.

CHN (carbon, hydrogen, and nitrogen) analysis was performed on some of the soot deposit that was scraped off of the syngas nozzle. Results were as follows:

$\begin{array}{lr}\text { Nitrogen } & 10.10 \text { wt } \% \\ \text { Hydrogen } & 2.27 \text { wt } \% \\ \text { Carbon } & 60.79 \text { wt } \% \\ \text { Ash (by difference) } & 26.84 \text { wt } \%\end{array}$

Since the carbon content of the sample is higher than that of PRB gasification ash (normally 20 to 45 percent, but never as high as 60 percent) the sample appears to be soot rather than gasification ash. The material is probably rust or other debris mixed with the soot. If all of the air entering the burner through the primary air jets is included, the primary stoichiometry when syngas is being burned is roughly 1.5. However, not all of the air from the primary jets recirculates. So it is likely that some part of the upstream end of the burner runs rich. Also, the flame temperature is lower when a mixture of syngas and propane is burned than when only propane is burned. Propane tends to form soot when burned rich and the tendency to form soot is increased when the flame temperature is lower. It is possible that the soot was formed from the pilot propane when propanesyngas mixtures were being burned. 


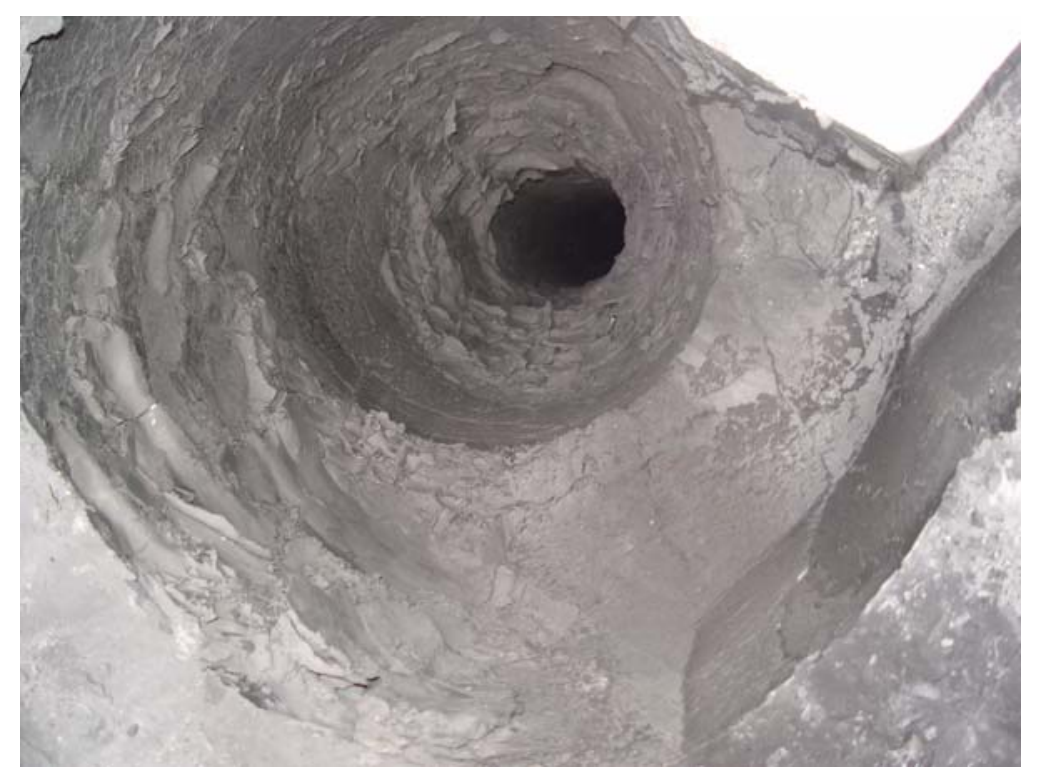

Figure 2.4-1 Cyclone Notch

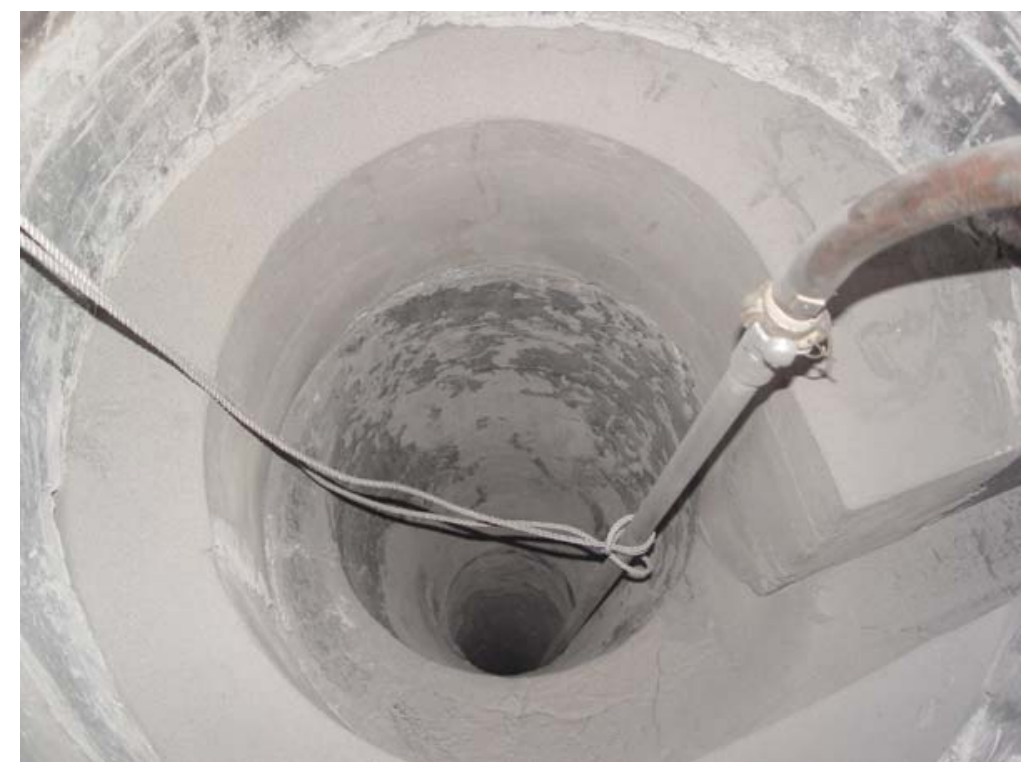

Figure 2.4-2 Repaired Cyclone 


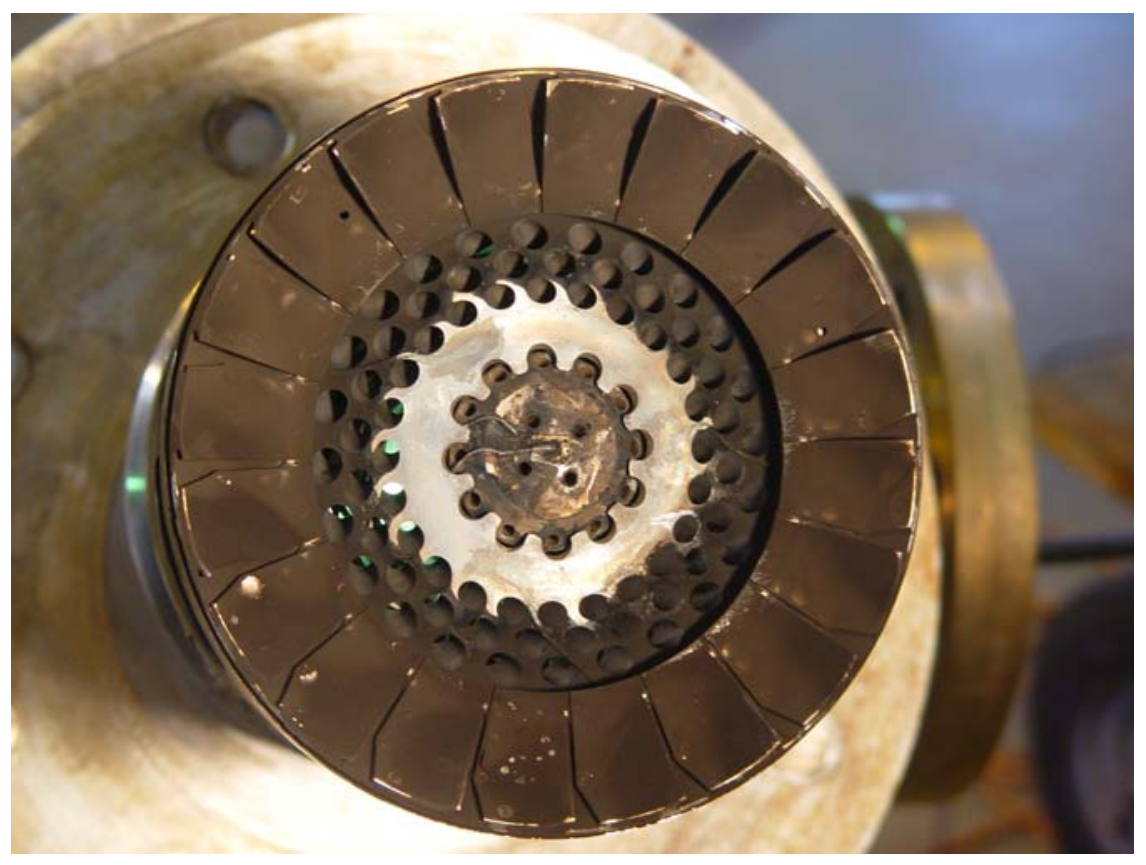

Figure 2.4-3 Piloted Syngas Burner (PSB) Nozzle Face

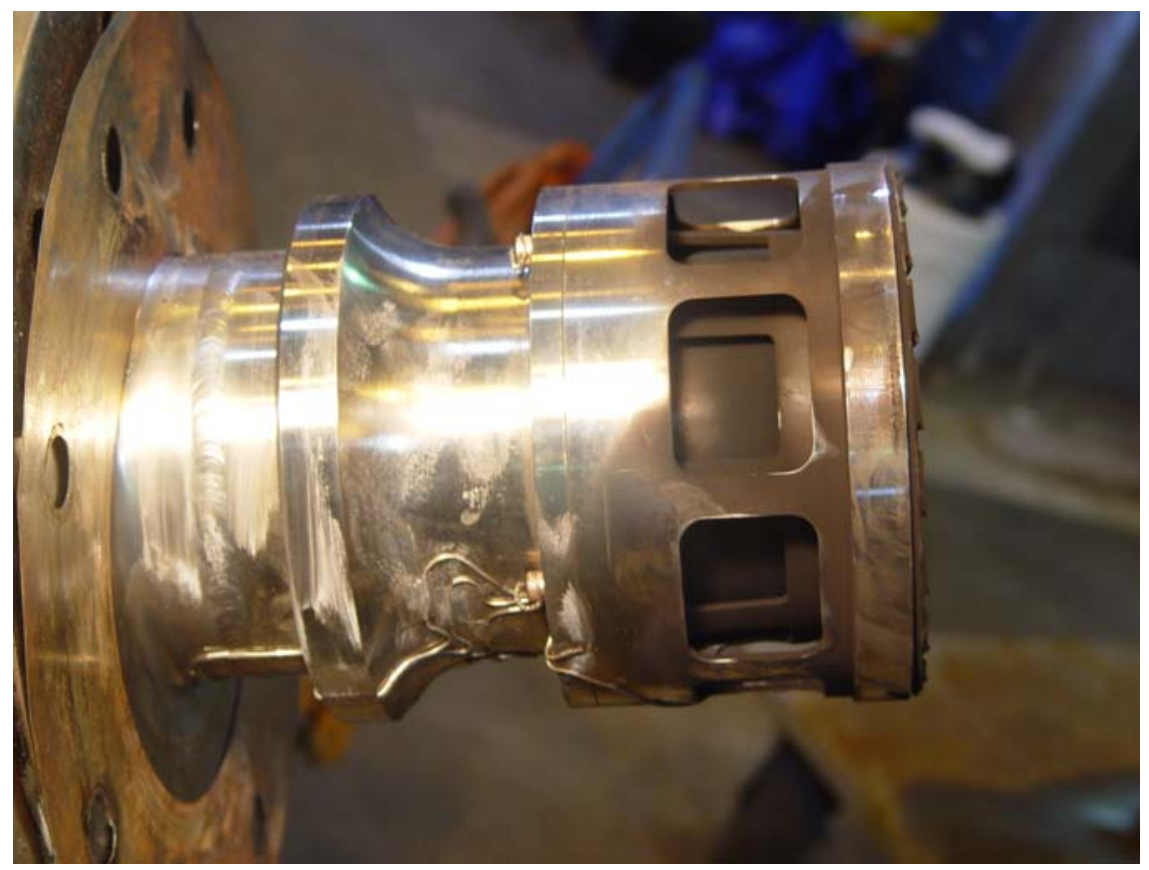

Figure 2.4-4 Side View of PSB Nozzle 


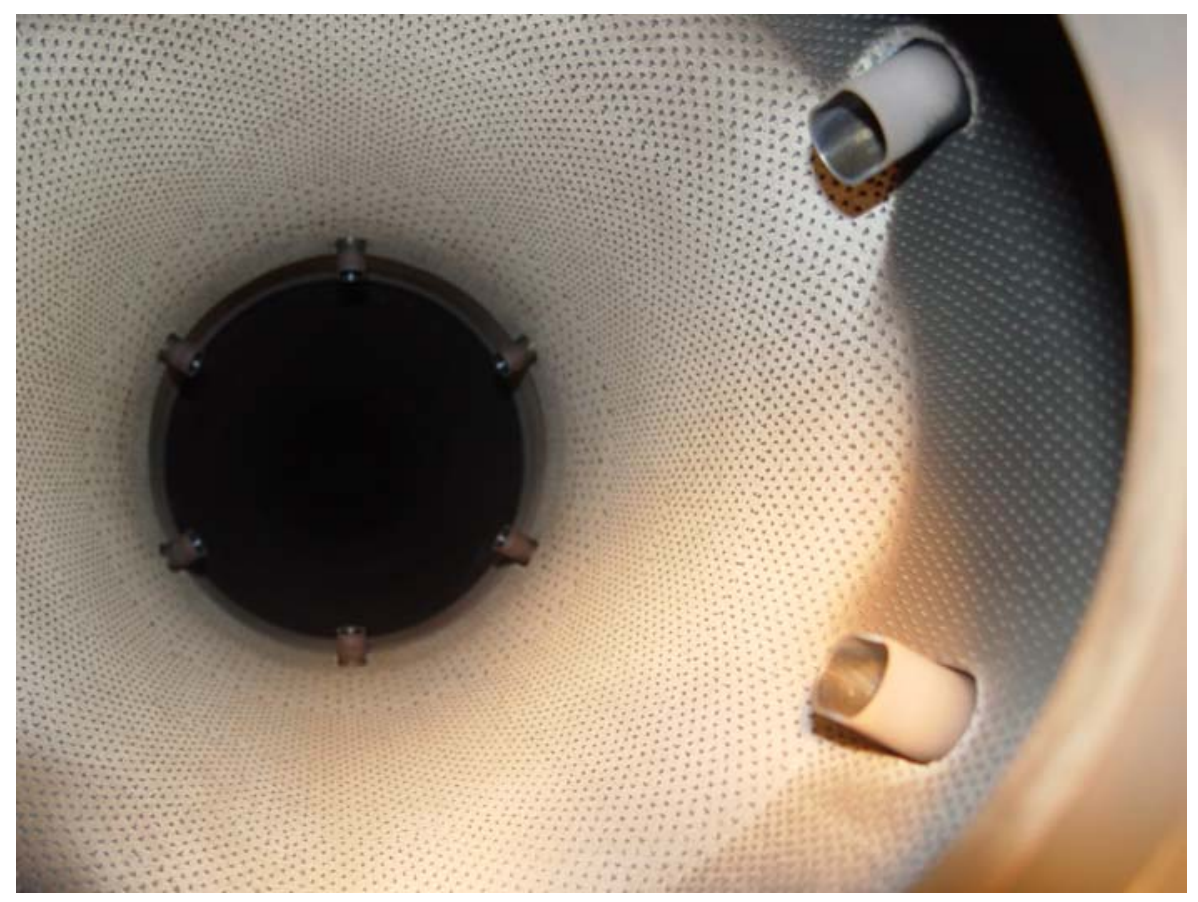

Figure 2.4-5 PSB Liner 


\subsection{PERFORMANCE}

\subsection{TRANSPORT GASIFIER PERFORMANCE}

Test campaign TC14 consisted of twenty periods of steady operation. These periods are given in Table 3.1-1. The operating periods had a cumulative time of about 193 hours, which was about 49 percent of the total TC14 on-coal operation time. The first 18 periods occurred during air blown operation, and the final 2 were in oxygen blown mode. No sorbent was used during TC14.

Table 3.1-2 lists the TC14 operating conditions, including the mixing zone temperature, the system pressure, PCD inlet temperature, coal feed rate, air rate, oxygen rate, syngas rate, steam rate, and nitrogen rate of the steady operating periods. The system pressure ranged from 188 to 212 psig for the air blown periods, but the pressure was reduced 160 during oxygen blown. Gasifier temperatures were between 1,701 and $1,781^{\circ} \mathrm{F}$. The steam flow rates were higher during oxygen blown testing, since steam was necessary to moderate temperatures in the gasifier near the oxygen injection point.

During TC14, syngas and flue gas analyzers were continuously monitored and recorded by the plant information system. Nine in situ samples were taken at the PCD outlet and measured for moisture content.

\subsubsection{Syngas Composition}

Plotted on Figure 3.1-1 are the AI475H, the syngas moisture analyzer, and the in situ $\mathrm{H}_{2} \mathrm{O}$ concentrations versus time. The moisture content during air-blown gasification was typically 10 percent. During oxygen blown gasification the moisture content increased to over 20 percent due to the higher steam flow rate necessary to control temperature.

The $\mathrm{H}_{2} \mathrm{O}$ concentrations used for the operating periods are given in Table 3.1-3. They ranged from 9.3 to 12.4 percent in air blown gasification and were 19.9 and 21.2 percent for the two oxygen blown gasification periods. Based on these moisture concentrations, the estimates of the wet gas compositions for the TC14 operating periods are given in Table 3.13 and shown on Figure 3.1-2. Also shown in Table 3.1-3 are the syngas molecular weights for each operating period.

The CO concentration typically ranged from 5.4 to 8.5 percent during air blown gasification. The CO content was 8.5 and 8.6 percent during the two oxygen blown periods. CO concentrations were usually higher in oxygen blown mode due to decreased nitrogen dilution.

The $\mathrm{H}_{2}$ concentration fluctuated between 5.0 and 7.8 percent during the air blown periods. After the transition to oxygen blown gasification, the hydrogen concentration increased to 
around 12 percent. The increase was due to the decrease in nitrogen dilution and the higher steam flow rates, which produced additional hydrogen due to the water gas shift reaction.

The $\mathrm{CO}_{2}$ concentration ranged from 8.6 to 10.0 percent during air blown gasification. During the two oxygen blown periods, the $\mathrm{CO}_{2}$ concentration increased to over 12 and 12.5 percent due to the decrease in nitrogen dilution and the water gas shift reaction.

During TC14, the $\mathrm{CH}_{4}$ concentration was between 0.7 and 2.0 percent. The methane content was not significantly higher during oxygen blown mode.

The $\mathrm{C}_{2}^{+}$concentration was assumed to be zero, since the gas analyzers were reading very low values.

The syngas molecular weight and nitrogen concentration are plotted on Figure 3.1-3. The air blown gasification molecular weights ranged between 26.1 and 27.0 pounds per pound mole. The oxygen blown molecular weights were 24.5 and 24.6 pounds per pound mole. The decrease in molecular weights during the oxygen blown period was due to the nitrogen being replaced by lower molecular weight compounds such as $\mathrm{H}_{2}$ and $\mathrm{H}_{2} \mathrm{O}$.

The $\mathrm{CO} / \mathrm{CO}_{2}$ ratios were calculated from the gas data for each operating period, and are listed in Table 3.1-3. The TC14 $\mathrm{CO} / \mathrm{CO}_{2}$ ratio varied from 0.6 to 0.9 .

When combusted in the syngas combustor, any sulfur compounds present in the syngas turns into $\mathrm{SO}_{2}$. Thus, projecting the sulfur content of the syngas is important. For the TC14 operating periods, the wet $\mathrm{H}_{2} \mathrm{~S}$ concentration measured by AI419J is plotted on Figure 3.1-4 and compared with the AI476 $\mathrm{N} \mathrm{SO}_{2}$ analyzer at the syngas combustor exit. Also plotted on the graph is the syngas total reduced sulfur (TRS), a value derived from the $\mathrm{SO}_{2}$ content at the syngas combustor exit. The wet $\mathrm{H}_{2} \mathrm{~S}$ concentration measured by AI419J and the syngas total reduced sulfur (TRS) are listed in Table 3.1-4. The AI419 analyzers measure the gas composition on a dry basis, so the values from AI419J were corrected to allow for moisture. The syngas combustor $\mathrm{SO}_{2}$ analyzer, AI476N, measures the total sulfur emissions from the Transport Gasifier. The main sulfur species in coal gasification are $\mathrm{H}_{2} \mathrm{~S}$ and carbonyl sulfide (COS). Other sulfur compounds, such as $\mathrm{CS}_{2}$ are present in small quantities.

The TRS concentration were $216 \mathrm{ppm}$ at the beginning of the test run and ran mostly between 200 and 300 ppm during the air blown test periods, with a few exceptions. After the transition to oxygen blown mode, the TRS increased to over $300 \mathrm{ppm}$ due to less nitrogen dilution. No limestone feed occurred in TC14, therefore, the only calcium present in the gasifier to capture sulfur came from the PRB coal ash. In previous PRB test runs, the use of sorbent has had little effect on syngas sulfur concentrations. The TRS concentrations are plotted versus the wet AI419 $\mathrm{J}_{2} \mathrm{~S}$ data on Figure 3.1-5.

The calculation of the minimum equilibrium syngas $\mathrm{H}_{2} \mathrm{~S}$ concentration has been described in previous PSDF reports. In summary, the minimum equilibrium $\mathrm{H}_{2} \mathrm{~S}$ concentration is a function of the partial pressures of $\mathrm{H}_{2} \mathrm{O}$ and $\mathrm{CO}_{2}$ as long as there is calcium sulfide present 
in the solids. (The equilibrium $\mathrm{H}_{2} \mathrm{~S}$ concentration is a function of system temperature, while the minimum equilibrium $\mathrm{H}_{2} \mathrm{~S}$ concentration is not a function of temperature.) As the partial pressures of $\mathrm{H}_{2} \mathrm{O}$ and $\mathrm{CO}_{2}$ increase, the $\mathrm{H}_{2} \mathrm{~S}$ concentration should increase. The minimum equilibrium $\mathrm{H}_{2} \mathrm{~S}$ concentrations were derived from chemical engineering simulations for all of the operating periods as listed in Table 3.1-4.

Figure 3.1-6 plots the TRS versus the minimum equilibrium $\mathrm{H}_{2} \mathrm{~S}$ concentration. The data are expected to all be above the 45 degree line since the minimum equilibrium $\mathrm{H}_{2} \mathrm{~S}$ concentration should be the lowest $\mathrm{H}_{2} \mathrm{~S}$ concentration in a system with calcium sulfide present. The oxygen blown data and some of the air blown data indicate removal beyond equilibrium, probably due to measurement errors. Many of the data points are close to the equilibrium line, as expected. The calcium in the PRB coal is present in high enough quantities to capture the sulfur.

Also shown on Table 3.1-4 are the ammonia concentrations in the syngas. The ammonia compositions ranged from 718 to $1876 \mathrm{ppm}$.

\subsubsection{Syngas Heating Values}

Raw Syngas Heating Values. The lower heating value (LHV) for each gas composition was calculated and is given on Table 3.1-3 and plotted on Figure 3.1-7.

The lower heating value was calculated using the formula:

$$
L H V(B t u / S C F)=\frac{275 \times\left(\mathrm{H}_{2} \%\right)+322 \times(C O \%)+913 \times\left(\mathrm{CH}_{4} \%\right)+1641 \times\left(\mathrm{C}_{2}{ }^{+} \%\right)}{100}
$$

During air blown gasification, the LHV typically ranged from 52 to $65 \mathrm{Btu} / \mathrm{SCF}$. One exception occurred during steady state period TC14-18 when the LHV was only 38 $\mathrm{Btu} / \mathrm{SCF}$. During this period, the coal feed rate was low and the nitrogen dilution per energy input of coal was high. The LHV was 77 and $79 \mathrm{Btu} / \mathrm{SCF}$ for the two oxygen blown periods.

One way to combine the effects of changing in the mode of operation (air versus oxygen blown), as well as the change in steam and coal feed rates is to determine the overall percent of oxygen of all the gas that enters the gasifier. The overall percent $\mathrm{O}_{2}$ is calculated by the following formula:

$$
\text { Overall Percent } \mathrm{O}_{2}=\frac{0.21 * \text { air }+ \text { oxygen }}{\text { air }+ \text { oxygen }+(\text { pure nitrogen })+\text { steam }}
$$

All flows are in moles per hour. At the PSDF, a large amount of pure nitrogen is fed to the gasifier for instrument purges, coal and sorbent transport, and equipment purges. During air 
blown gasification about half of the nitrogen flowing through the gasifier comes from these pure nitrogen flows, and the remainder comes from the nitrogen in the air. When operating in oxygen blown gasification, the nitrogen in the gasifier is predominantly due to the pure nitrogen flows.

The TC14 overall percent $\mathrm{O}_{2}$ is listed in Table 3.1-3. The values range from 11.2 to 13.1 percent $\mathrm{O}_{2}$ in air blown mode and from 13.7 to 14.2 percent $\mathrm{O}_{2}$ in oxygen blown mode. As the overall percent $\mathrm{O}_{2}$ increases, the LHV also increases. The overall percent $\mathrm{O}_{2}$ is higher in oxygen blown gasification than in air blown gasification due to less nitrogen dilution.

The TC14 raw LHV data are plotted against overall percent $\mathrm{O}_{2}$ on Figure 3.1-8. By comparison, the curves of previous data with PRB subbituminous (TC06, TC07, TC08, TC10, TC12, and TC13), Hiawatha bituminous (TC09), Falkirk lignite (TC11), and Freedom lignite (TC13) coals are included.

Projected Syngas Heating Values. The PSDF Transport Gasifier produces syngas of a lower quality than a commercial-sized gasifier due to:

- The use of recycle gas rather than nitrogen for aeration and PCD backpulsing.

- A lower heat loss per pound coal gasified because of a lower surface area to volume ratio.

- A smaller number of instruments and instrument purges.

- A cold gas cleanup train to remove contaminants and water from the syngas.

For details on the projected LHV calculation, see Appendix 5.

The projected LHV and composition data for syngas at the gasifier outlet for each operating period are given in Table 3.1-5. The air blown commercially projected LHVs were between 90 and $127 \mathrm{Btu} / \mathrm{SCF}$ for air blown operation and were 204 and $208 \mathrm{Btu} / \mathrm{SCF}$ for the two oxygen blown periods. The last column in the Table 3.1-5 gives the cold syngas LHV, which is turbine inlet value, i.e., the value after water removal in the syngas cleanup train.

For comparing the raw lower heating values with the projected lower heating values, an equivalent to the projected overall percent $\mathrm{O}_{2}$ is defined as:

$$
\text { Projected Overall Percent } \mathrm{O}_{2}=\frac{0.21 *(\text { projected air })+(\text { projected oxygen })}{(\text { projected } \text { air })+(\text { projected } \text { oxygen })+(\text { projected } \text { steam })}
$$

All flow rates are expressed as moles per hour.

The PRB projected LHV is plotted against the projected overall percent $\mathrm{O}_{2}$ on Figure 3.1-9. The linear fits of the projected Powder River Basin LHV data, the projected Falkirk lignite LHV data, the projected Hiawatha bituminous LHV data, and the projected Freedom lignite data from previous test campaigns are also shown on Figure 3.1-9. The TC14 PRB projected LHV data are consistent with the average previous PRB projected data. Based on 
data from this test campaign, the projected lower heating values at the gas turbine inlet ranged from 110 to $151 \mathrm{Btu} / \mathrm{SCF}$ and approximately $267 \mathrm{Btu} / \mathrm{SCF}$ for oxygen blown operation as shown in Table 3.1-5.

\subsubsection{Gasifier Solids Analyses}

During TC14, the solid samples were taken from the following locations:

- The coal feeder (FD0210).

- The gasifier standpipe (circulating solids).

- The gasifier loop seal downcomer.

- The PCD fines removal lock-hopper system (FD0520).

- The new continuous fine ash depressurization system (CFAD or FD0540).

In situ solids samples were also collected from the PCD inlet. The solid samples were analyzed for chemical composition and particle size.

Table 3.1-6 gives the average coal composition including the hydrogen, nitrogen, oxygen, sulfur, ash, volatiles, fixed carbon, $\mathrm{CaO}, \mathrm{SiO}_{2}, \mathrm{Al}_{2} \mathrm{O}_{3}, \mathrm{MgO}, \mathrm{Na}_{2} \mathrm{O}$, and $\mathrm{Fe}_{2} \mathrm{O}_{3}$ contents as well as the average molar ratios for coal calcium to sulfur ratio $(\mathrm{Ca} / \mathrm{S})$ as well as the standard deviation for the samples analyzed as sampled from the FD0210 coal feeder. The fuel carbon and moisture contents are shown in Figure 3.1-10 and the average values are shown in Table 3.1-6. Both the moisture and the carbon content of the PRB coal remained essentially constant during TC14.

Figure 3.1-11 shows the fuel sulfur and ash as sampled from the FD0210 coal feeder during TC14. The PRB sulfur level remained between 0.23 and 0.29 weight percent. The sulfur weight percent at hour 163 was neglected from the average coal sulfur in Table 3.1-6. The ash content was constant, at around 5 weight percent, a typical value for PRB coal.

The higher heating value (HHV) and lower heating value (LHV) of the coal are given on Figure 3.1-12 with the TC14 average value given in Table 3.1-6. The coal HHV is determined using a bomb calorimeter. The calorimeter condenses all the coal combustion moisture as liquid water. The LHV is calculated by subtracting the heat of vaporization of the coal moisture from the HHV. Since heat recovery steam generators do not recover the coal syngas moisture heat of vaporization, the LHV is a more meaningful measure of coal heating value. The heating values for the PRB coal were fairly constant, although the heating value increased about $300 \mathrm{Btu} / \mathrm{lb}$ at the end of the test run.

Also shown in Table 3.1-6 are the average coal compositions.

The chemical compositions of the solid compounds produced by the Transport Gasifier were determined based on the chemical analysis and the following assumptions: 
1. All carbon dioxide measured came from $\mathrm{CaCO}_{3}$, hence moles of $\mathrm{CO}_{2}$ measured equals moles of $\mathrm{CaCO}_{3}$.

2. All sulfide sulfur measured came from $\mathrm{CaS}$.

3. All calcium not taken by $\mathrm{CaS}$ and $\mathrm{CaCO}_{3}$ came from $\mathrm{CaO}$.

4. All magnesium came from $\mathrm{MgO}$.

5. Total carbon is measured, which is the sum of organic and inorganic $\left(\mathrm{CO}_{2}\right)$ carbon. The organic carbon is the total carbon minus the inorganic carbon $\left(\mathrm{CO}_{2}\right)$.

6. All iron reported as $\mathrm{Fe}_{2} \mathrm{O}_{3}$ is assumed to be present in the gasifier and PCD solids as FeO. Thermodynamically, the mild reducing conditions in the Transport Gasifier should reduce all $\mathrm{Fe} 2 \mathrm{O} 3$ to $\mathrm{FeO}$.

7. Inerts are the sum of the $\mathrm{BaO}, \mathrm{P}_{2} \mathrm{O}_{5}, \mathrm{Na}_{2} \mathrm{O}, \mathrm{K}_{2} \mathrm{O}$, and $\mathrm{TiO}_{2}$ concentrations.

Both elemental sulfur (ultimate analysis) and ash inerts sulfur contents were measured. It is assumed that no FeS is formed in the Transport Gasifier and that all the sulfur in the standpipe and PCD solids is present as CaS. Thermodynamically some FeS formation is possible, but most of the captured sulfur should be in the form of $\mathrm{CaS}$ due to the larger concentration of calcium than iron in the system.

Table 3.1-7 gives the results from the standpipe solids analysis. These solids re-circulate through the mixing zone, riser, and standpipe. Typically, the properties of these solids change slowly with time. Due to low solids capture efficiency, the coarse standpipe spent solids transporter system operated only during the early portion of TC14 to control the standpipe level (Flow rates for the PCD solids during the stable operating periods are given in Table 3.1-2).

The poor performance of the solids collection system caused a loss of bed material throughout the test run. To maintain adequate solids circulation, sand was fed to the gasifier throughout the test campaign. Due to the frequent additions of sand, the standpipe solids silica content was higher than normal and ranged between 83 and 89 weight percent. Figure 3.1-13 shows the standpipe $\mathrm{SiO}_{2}, \mathrm{CaO}$, and $\mathrm{Al}_{2} \mathrm{O}_{3}$ contents versus run time.

The gasifier solids organic carbon content is plotted on Figure 3.1-14. The organic carbon is the total carbon in the solids minus inorganic carbon measured as $\mathrm{CO}_{2}$. For the standpipe solids, only 4 of the 13 solid samples were analyzed for $\mathrm{CO}_{2}$. For the other nine samples, the solids $\mathrm{CO}_{2}$ content was interpolated from the $\mathrm{CO}_{2}$ content of the analyzed samples. Based on previous experience, the standpipe organic carbon content is a very inaccurate measurement because the value comes from a difference of two small values that are nearly equal. The standpipe organic carbon content was less than 1 percent for all but two samples. In general, the standpipe solids carbon content was higher in TC14 than it was in previous test campaigns due to an increase an increase in temperature drop through the gasifier which was in turn due to low circulation rates.

The standpipe solids $\mathrm{CaS}$ content was negligible for all of the standpipe samples. The calcium in the PRB coal ash captured a minimal amount of sulfur which is consistent with previous PRB test data. The standpipe $\mathrm{CaCO}_{3}$ was constant between 1.3 and 1.5 percent for TC14. About 79 percent of the calcium in the standpipe solids was calcined to $\mathrm{CaO}$. 
Table 3.1-8 lists the analysis results for the loop seal downcomer. The solids from the loop seal downcomer are the solids that pass through the disengager with the syngas, and are separated from the gas stream in the cyclone. After the cyclone captures the loop seal solids, they flow back to the standpipe where they join the solids collected by the disengager.

Figure 3.1-15 shows the $\mathrm{CaO}, \mathrm{SiO}_{2}$, and $\mathrm{Al}_{2} \mathrm{O}_{3}$ contents of the samples taken from the loop seal downcomer. The loop seal solids concentrations were similar to those from the standpipe, having near constant low levels of $\mathrm{SiO}_{2}, \mathrm{CaO}$, and $\mathrm{Al}_{2} \mathrm{O}_{3}$ due to frequent sand addition. The loop seal solids did have a slightly lower $\mathrm{SiO}_{2}$ content than the standpipe solids—about 10 percent less silica_-due to the smaller particle size of the loop seal particles as discussed below.

Figure 3-1.16 shows the organic carbon (total carbon minus $\mathrm{CO}_{2}$ carbon) contents for the loop seal solids. The carbon content of the solids is higher in the loop seal than the standpipe (4 to 12 percent versus 0 to 3 percent), because a greater percentage of the smaller carbon particles are collected by the cyclone rather than the less efficient disengager.

The $\mathrm{MgO}, \mathrm{Fe}_{2} \mathrm{O}_{3}$, and other inerts contents follow the same trend as the $\mathrm{Al}_{2} \mathrm{O}_{3}$ due to the frequent sand additions. The loop seal solids $\mathrm{CaS}$ content was negligible for all samples. The loop seal $\mathrm{CaCO}_{3}$ slowly increased from 1.8 to 4.6 percent.

Figure 3.1-17 plots the organic carbon for the PCD solids sampled from the FD0520 or FD0540 solids removal systems. Since the new continuous fine ash depressurization system (FD0540) was in use for the majority of the run, all but three of the samples (indicated on Figure 3.1-17 and all other PCD solids plots) came from the FD0540 feeder. The complete solids analysis as well as organic carbon content for the PCD samples is given in Table 3.1-9. In situ PCD inlet particulate solid samples were also analyzed.

The in situ carbon contents are compared with the FD0520 and FD0540 solids samples on Figure 3.1-17. The in situ solids organic carbon analyses were in agreement with the FD0520/FD0540 solids for five of the seven samples.

The first PCD sample was taken only three hours after coal feed began and therefore the organic carbon content was low, only 2.7 percent. The carbon content remained between 20 and 60 percent for the rest of the test run, with the exception of FD0540 samples taken at hours 179 and 203. These samples had carbon contents of 9.8 percent and 3.4 percent, respectively. Both of these samples were taken during or just after periods of sand addition. The poor cyclone performance and resulting sand additions skewed the results of the PCD samples.

Figure 3.1-18 and Table 3.1-9 show the amounts of $\mathrm{SiO}_{2}$ and $\mathrm{Al}_{2} \mathrm{O}_{3}$ in the PCD solids as sampled from FD0520 and FD0540. Also plotted on Figure 3.1-18 are the in situ solids concentrations for $\mathrm{SiO}_{2}$ and $\mathrm{Al}_{2} \mathrm{O}_{3}$. 
The $\mathrm{SiO}_{2}$ PCD fines concentrations are a function of the efficiency of the disengager and cyclone as well as the $\mathrm{SiO}_{2}$ concentration of circulating solids in the gasifier. The $\mathrm{SiO}_{2}$ in the PCD fines is made of fresh coal ash $\mathrm{SiO}_{2}$, start-up sand $\mathrm{SiO}_{2}$ that is being lost from the gasifier, and additional sand that is added to the gasifier to increase standpipe level. The $\mathrm{SiO}_{2}$ PCD fines concentration widely fluctuated between 20 and 90 percent due to the frequent sand additions. Typically, the $\mathrm{SiO}_{2}$ content falls below 30 percent within a few days after startup.

Since only a minimal amount of $\mathrm{Al}_{2} \mathrm{O}_{3}$ is in the start up sand, the majority of the PCD solids $\mathrm{Al}_{2} \mathrm{O}_{3}$ content comes from the coal ash. The PCD fines $\mathrm{Al}_{2} \mathrm{O}_{3}$ concentration remained low, between 3 and 8 percent, for the majority of the test run.

Figure 3.1-19 shows the total calcium concentration as well as the concentration of CaS in the PCD solids as sampled from FD0520 and FD0540. The concentrations for $\mathrm{CaO}, \mathrm{CaS}$, and $\mathrm{CaCO}_{3}$ are also listed in Table 3.1-9. Also plotted on Figure 3.1-19 are the calcium and $\mathrm{CaS}$ concentrations for the in situ solids samples. All of the in situ samples calcium and $\mathrm{CaS}$ concentrations agreed well with FD0520 and FD0540 solids calcium and calcium sulfide concentrations. The PCD solids calcium concentration fluctuated from less than 1 percent to almost 9 percent. There was no limestone feed during the test run, so all of the PCD fines calcium came from the PRB coal ash. The PCD fines CaS concentration for PRB was less than 1.0 percent for the entire test run, indicating very low sulfur capture due.

The PCD fines calcination is defined as:

$$
\% \text { Calcination }=\frac{m o l \% C a O}{m o l \% C a O+m o l \% C a C O}
$$

The PCD fines calcination data are plotted on Figure 3.1-20. The PCD fines calcination ranged from 5 to 84 percent, with most data points between 40 and 80 percent. Previous PRB testing yielded calcination percentages between 60 and 80 percent. Sand dilution of the PCD samples is the most likely cause of this wider variation.

The calcium sulfation is defined as:

$$
\% \text { Sulfation }=\frac{m o l \% C a S}{m o l \% C a O+m o l \% C a C O_{3}+m o l \% C a S}
$$

The PCD fines sulfation is plotted on Figure 3.1-20 with the PCD fines calcination. The PCD fines sulfation varied between 2 and 6 percent for most of the test run. After the transition to oxygen blown gasification, the sulfation percentage dropped below 1 percent and remained there until the end of the test run. These values indicate that only a minimal amount of sulfur capture took place, although sand dilution of the PCD samples likely skewed these values 
Solids Sample Comparison. The following comparison of the analysis of the coarse standpipe solids, the loop seal downcomer solids, and the PCD fines solids shows how the solids compositions change throughout the process.

Figure 3.1-21 compares the organic carbon content of the standpipe, loop seal, and PCD fines solids samples. The PCD solids carbon content ranged from 10 to 58 percent, with the high variability due to sand addition. The loop seal organic carbon content ranged between 4 and 12 percent, and the standpipe solids carbon content was between 0 and 3 percent. These data seem to indicate that the carbon is contained in small particles which are only partially captured by the disengager. The cyclone separates a larger portion of the carbon, and the PCD collects the rest.

Figure 3.1-22 compares the calcium concentration between the standpipe, the loop seal, and the PCD fines solids samples. The calcium content was the generally highest for the PCD solids, ranging from 3 to 9 percent. The standpipe and loop seal fines solids calcium contents remained within two to four percent of each other. The standpipe and loop seal calcium contents were relatively constant, while the PCD calcium content changed, probably due to the dilution caused by the frequent sand addition. The higher PCD solids calcium content indicated that the calcium was concentrated in the smaller particles that passed through the disengager and cyclone. (Note that the calcium is distributed between the compounds $\mathrm{CaO}, \mathrm{CaCO}_{3}$, and $\mathrm{CaS}$.)

The silica entering the process primarily remains in the gasifier, since the sand particle size is greater than that of the gasifier spent solids. Figure 3.1-23 shows that the standpipe solids had the highest silica content, followed by the loop seal. The PCD solids had the lowest silica content, but it fluctuated over a larger range, becoming higher during periods of poor solids collection performance and sand addition. Typically, the sand loss through the cyclone is minimal. However, in TC14 sand feed was more frequent than in previous test runs so the silica inventory in the gasification loop never reached steady state.

Solids Particle Size. The TC14 Sauter mean diameter (SMD) and mass mean diameter (MMD) particle sizes of the coal sampled from the FD0210 coal feeder are plotted on Figure 3.1-24. The PRB coal SMD particle size was fairly steady, from just under 187 to 315 microns. The average SMD for the PRB was 246 microns, with a standard deviation of 37 microns.

Past test campaign average and standard deviation SMD, MMD, percent particles above 1,180 microns, and percent particles below 45 microns are given in Table 3.1-10. The TC14 PRB SMD data were consistent with the data for all previous PRB testing. The average MMD was 418 microns with a standard deviation of 74 microns. As is typical the coal MMD is larger than the SMD. The MMD, ranging from 335 to 597 microns, had more variation than the PRB SMD and was higher than typical PRB test runs. The MMD fluctuated around 400 microns during TC14, with two spikes over 500 microns at hours 67 and 147. 
Figure 3.1-25 plots both the coal feed percent above 1,180 microns (coarse particles) and percent below 45 microns (fines). A large amount of 1,180 micron particles increases the difference between the SMD and the MMD, because the SMD is a surface area average. Therefore, the larger particles with less surface area per pound have a weaker effect on the SMD than the MMD, where the larger particles skew the MMD due to their higher weight per particle.

The average percent above 1,180 microns for TC14 was 10.3 percent with a standard deviation of 3.5 percent. The TC14 percentage of coal above 1,180 microns was higher than the typical average percent above 1,180 microns for PRB test campaigns. The percent above 1,180 varied during the entire test run, mostly between 5 and 12 percent, but occasionally spiked to 15 percent or higher. The high spikes in coarse solids correspond to the high MMD particle size.

In past testing, a high fines content in the feed coal resulted in an increased number of coal feeder outages due the packing of coal fines in the coal feed system lock vessel. These problems did not occur in TC14. The PRB average percent below 45 microns was 7.0 percent with a standard deviation of 2.7 percent, lower than typical PRB test runs. The majority of the coal samples had fines percentages around 5 percent. The values spiked occasionally to 11 or 12 percent with the samples taken at hours 99, 107, 131, and 203. Even during these periods, the coal lock vessel did not experience any packing.

The TC14 standpipe solids particle sizes are given in Figure 3.1-26. The PRB standpipe solids particle sizes remained constant as the run progressed due to the numerous sand additions in TC14. The particle size did increase slightly at the end of the test run, as the system transitioned to oxygen blown mode. The average particle size of the standpipe solids was around 171 microns MMD and 197 microns SMD.

The percent of gasifier solids greater than 600 micron particles and the percent less than 45 microns are plotted on Figure 3.1-27. During TC14 operation, the gasifier solids had an average coarse particle (greater than 600 microns) content of above 1.4 percent and an average fines content (less than 45 microns) of around 0.2 percent. The addition of sand kept the particle size consistent throughout the test run, and no fluidization problems occurred.

For some of the previous test campaigns, the gasifier recirculating solids achieved a steady particle size, typically between 165 and 205 microns SMD as shown in Table 3.1-11. By comparison, the startup sand is around 120 microns SMD. For tests that reached steady state the standpipe particle size slowly increased asymptotically to reach the steady state value. Due to the numerous sand additions, the standpipe solids never reached a steady state composition. The TC14 maximum standpipe particle size was consistent with those of the previous PRB test campaigns as shown in Table 3.1-11.

The particle sizes of the loop seal solids are as shown in Figure 3.1-28. Both the SMD and the MMD of the loop seal solids varied widely. The SMD ranged from 9.8 to 56.9 microns, while the MMD varied from 24.0 to 113.8 microns. 
Figure 3.1-29 plots the SMD and MMD for the PCD solids sampled from the FD0520 and FD0540 solids removal systems as well as the seven in situ samples taken at the PCD inlet. Four of the seven in situ solids particle sizes agreed with the particle size of the solids collected from the hoppers. One reason for the disagreement with the other three samples may have been sand addition. In order to collect a representative sample of gasification ash, most of the in situ samples were collected during periods when sand was not being added to the gasifier. The hopper samples were taken at times when sand was being added.

The PCD fines SMD started TC14 around 25 microns, and typically ranged from 7 to 32 microns for the remainder of the run, with three outliers at 38, 54, and 85 microns. The MMD was about 10 to 15 microns larger than the SMD for most of the samples and followed the same trends as the SMD particle size. The in situ PCD inlet MMD solids particle size also showed the same trend of disagreement with the FD0520/FD0540 solids MMD particle size during the spikes. The TC14 PCD fines particle size was consistent with the particle size of previous PRB test campaigns as shown in Table 3.1-11.

Particle Size Comparison. Figure 3.1-30 plots the solids SMD particle sizes, including the coal, standpipe solids, loop seal solids, and PCD fines from FD0520 and FD0540. The coal fed to the Transport Gasifier averaged 246 microns SMD, approximately the same size as the standpipe solids. The loop seal solids are typically more coarse than the PCD solids, but less coarse than the standpipe solids. Occasionally, the particle size of the PCD solids is greater than that of the loop seal solids. This anomaly was probably due to the poor solids collection and frequent sand additions.

Standpipe and PCD Fines Bulk Densities. The standpipe, loop seal, PCD in situ, and FD0520/FD0540 fines bulk densities are given in Figure 3.1-31. As previously mentioned, the standpipe solids bulk density remained constant due to the frequent sand additions that were necessary. The standpipe solids bulk density averaged 92 pounds per cubic feet, a value close to that of pure sand. Falling between the standpipe and PCD bulk density data, the data for the loop seal solids averaged 61 pounds per cubic feet, but varied considerably more than the standpipe solids data. Since the disengager captured most of the sand particles, the loop seal solids varied more with the coal fed. The PCD solids had the greatest variation in bulk density and the lowest average values, around 27 pounds per cubic feet for the material removed from FD0540. All of the in situ PCD data points were in the general range of the FD0520/FD0540 sample data. Of the three different samples, the PCD solids bulk density was the least dependent on sand addition and most dependent on coal fed.

The minimum standpipe solids densities for past PSDF gasification test campaigns are shown in Table 3.1-11. Also listed are the average SMD particle size and standard deviation of the PCD fines for all previous gasification test campaigns. As expected, the frequent sand additions increased the average SMD of the particles in TC14. For example, the average SMD of the PCD fines in TC14 was 18.7 microns, slightly higher than that of previous PRB test runs. The standard deviation of the fines SMD was considerably higher than that of other PRB tests, reaching 14.6 microns. 


\subsubsection{Carbon Conversion}

Carbon conversion is defined as the percent of fuel carbon that is gasified to $\mathrm{CO}, \mathrm{CO}_{2}, \mathrm{CH}_{4}$, $\mathrm{C}_{2} \mathrm{H}_{6}$, and higher hydrocarbons versus the amount of carbon remaining in PCD and gasifier solids.

The carbon conversion can be calculated at least three different ways:

1. Gas analysis method - this method is based on the feed carbon (coal) and the carbon in the syngas. The gas analysis method assumes that the feed carbon and the syngas carbon are correct.

2. Solids analysis method - this method is based on the feed carbon and the syngas carbon determined by a gasifier carbon balance, not the syngas analysis. The solids analysis method assumes that the syngas analyzers or flow rates are incorrect.

3. Products analysis method - this method is based on the feed carbon determined by a Transport Gasifier carbon balance and the syngas carbon. The products analysis assumes that the coal feed rate is in error.

The carbon conversions using all three methods are plotted on Figure 3.1-32 and shown in Table 3.1-12. All three methods would agree if the carbon balance were perfect. The carbon conversions by the solids and products method are approximately the same for TC14. The carbon conversion by the gas method is greater than the carbon conversion by the products method when the carbon balance error is less than zero and is greater than the products method when the carbon balance error is greater than zero. The products method is the most reasonable since it is not based on the coal rate, but on the syngas and PCD solids rates.

The products method carbon conversion ranged from 78 to 93 percent during air-blown testing. During oxygen-blown testing, the carbon conversion was around 91 percent. Note that the carbon conversion was lower during periods in which the PCD solids rate was higher. During these periods, the solids collection system performed poorly, and more fine carbon particles exited the gasifier without being recycled, thus lowering the carbon conversion.

The average carbon conversions of PRB, Hiawatha bituminous, Falkirk lignite coal, and Freedom lignite are compared on Figure 3.1-33 for both air and oxygen operation. These data came from test campaigns TC06 through TC13. The low temperature Freedom lignite carbon conversion data are plotted separately from the high temperature Freedom lignite carbon conversion data to illustrate that significantly lower temperatures adversely affect the carbon conversion. For all fuels, air blown operation yielded a slightly higher carbon conversion than oxygen blown operation. Only for Hiawatha bituminous coal, however, is the difference between air and oxygen blown mode larger than the standard deviation of the average values. 
Falkirk lignite had the highest average carbon conversion of the four coals tested. PRB and Freedom lignite had about the same average carbon conversion, while Hiawatha bituminous coal had the lowest average carbon conversion. Although the data in Figure 3.1-33 show general trends in carbon conversion over test runs, the values obtained are the result of operating over a small range of conditions. Optimizing the gasifier operating conditions can improve these values.

\subsubsection{Gasification Efficiencies}

Gasification efficiency is defined as the percentage of the entering energy (coal energy and steam energy) that is converted to potentially useful syngas energy. Two types of gasification efficiencies have been defined, the cold gasification efficiency and the hot gasification efficiency. The cold gasification efficiency is the amount of energy fed that is available to a gas turbine as syngas latent heat. The hot gasification efficiency is the percentage of feed energy that is available in the syngas to power a gas turbine plus a heat recovery steam generator.

The cold gasification efficiency can be calculated several different ways. The most accurate method is based on the feed heat determined by the gasifier energy balance and the syngas sensible heat. This method assumes that the coal feed or the steam rate is in error. The cold gasification efficiency is plotted in Figure 3.1-34 and is listed in Table 3.1-13. The cold gasification efficiencies were as high as 56 percent during the test run. During the air blown operating periods, the cold gasification efficiencies ranged from 40.0 to 54.1 percent. The two oxygen blown periods had cold gasification efficiencies of around 56.3 percent and 56.6 percent.

Figure 3.1-35 shows the trend in cold gasification efficiency with the calculated steam to coal ratio. As the steam to coal ratio increases, the cold gasification efficiency decreases, though the effect is not as pronounced in TC14 due to the narrow range of steam to coal ratios used. The oxygen blown operating periods both had high cold gasification efficiencies than the air blown modes did despite their higher steam to coal ratio, since a large volume of air had to be heated in air blown mode, decreasing the cold gasification efficiency. The steam rate effect on cold gasification efficiency is not due to steam dilution but due to the increased loss in efficiency of heating steam to the Transport Gasifier temperature.

The hot gasification efficiency assumes that the sensible heat of the syngas can be recovered in a heat recovery steam generator, so the hot gasification efficiency is always higher than the cold gasification efficiency. Like the cold gasification efficiency, the hot gasification efficiency can also be calculated several different ways, but the most accurate is also based on the feed heat determined by the Transport Gasifier energy balance and the syngas sensible heat. The hot gasification efficiency is plotted in Figure 3.1-36 and shown in Table 3.1-13.

The air blown hot gasification efficiencies were between 71.1 and 83.4 percent, with the periods of lowest efficiency occurring either during the periods of high PCD solids carryover 
(TC14-11, TC14-12, TC14-13) or low coal feed rate (TC14-18). The two oxygen blown periods had efficiencies of around 80 percent. The oxygen blown hot gasification efficiencies are similar to the air blown hot gasification efficiencies, even though they have much higher steam to coal ratios, because the hot gasification efficiency recovers the sensible heat of the additional nitrogen in air blown mode.

The two main sources of efficiency losses are the gasifier heat loss and the latent heat of the PCD solids. The gasifier heat loss of 3.5 million Btu/hr was about 10 percent of the feed energy, while the total energy of the PCD solids was from 4 to 20 percent of the feed energy (the higher numbers occurring during the periods of high PCD carryover). The heat loss percentage will decrease as the gasifier size is increased. While the Transport Gasifier does not recover the latent heat of the PCD solids, this latent heat could be recovered in a combustor. The total enthalpy of the PCD solids can be decreased by decreasing both the PCD solids carbon content (heating value) and the PCD solids rate (by improving solids collection efficiency).

Gasification efficiencies can be calculated from the commercially projected gas heating values and adjusted flow rates that were determined when calculating the projected heating value. The commercially projected cold gasification efficiencies are listed on Table 3.1-13 for all of the operating periods. The projected hot gasification efficiencies are not shown, as the commercial projections do not increase the hot gasification efficiency because the deleted nitrogen lowers the syngas sensible heat and increases the syngas latent heat. Both changes effectively cancel each other.

The corrected efficiencies are calculated assuming an adiabatic gasifier, since zero heat loss was one of the assumptions in determining the corrected LHV in Section 3.1.3. The corrected cold gasification efficiencies were from 58.2 to 72.8 percent in air blown mode, and just under 77 percent in oxygen blown mode. The average cold gasification efficiency for air blown mode was 66.5 percent.

The commercially projected efficiencies were higher than the observed cold gasification efficiencies by about 16 percent in air blown mode and 20 percent in oxygen blown mode. The use of recycle gas and the lower heat losses in the commercial projection are the main reasons for the increase in efficiency. 
Table 3.1-1 Operating Periods

\begin{tabular}{|c|c|c|c|c|c|}
\hline \multirow[b]{2}{*}{$\begin{array}{c}\text { Operating } \\
\text { Period }\end{array}$} & \multirow[b]{2}{*}{$\begin{array}{l}\text { Start } \\
\text { Time }\end{array}$} & \multirow[b]{2}{*}{$\begin{array}{l}\text { End } \\
\text { Time }\end{array}$} & \multirow[b]{2}{*}{$\begin{array}{c}\text { Duration } \\
\text { Hours }\end{array}$} & \multicolumn{2}{|c|}{ Operating Period } \\
\hline & & & & $\begin{array}{c}\text { Average } \\
\text { Time }\end{array}$ & $\begin{array}{c}\text { Relative } \\
\text { Hours }\end{array}$ \\
\hline TC14-1 & 2/20/04 11:30 & 2/20/04 15:00 & $3: 30$ & 2/20/04 13:15 & 10 \\
\hline TC14-2 & 2/20/04 20:00 & 2/21/04 1:30 & $5: 30$ & 2/20/04 22:45 & 20 \\
\hline TC14-3 & 2/21/04 3:00 & 2/21/04 8:30 & $5: 30$ & 2/21/04 5:45 & 27 \\
\hline TC14-4 & 2/21/04 9:00 & 2/21/04 12:00 & $3: 00$ & 2/21/04 10:30 & 32 \\
\hline TC14-5 & 2/21/04 17:00 & 2/22/04 5:45 & $12: 45$ & 2/21/04 23:22 & 44 \\
\hline TC14-6 & 2/22/04 15:45 & 2/22/04 22:00 & $6: 15$ & 2/22/04 18:52 & 64 \\
\hline TC14-7 & $2 / 23 / 046: 00$ & 2/23/04 8:00 & $2: 00$ & $2 / 23 / 04$ 7:00 & 76 \\
\hline TC14-8 & 2/23/04 20:00 & 2/24/04 1:00 & $5: 00$ & 2/23/04 22:30 & 92 \\
\hline TC14-9 & 2/24/04 10:30 & 2/24/04 13:45 & $3: 15$ & 2/24/04 12:07 & 105 \\
\hline TC14-10 & 2/24/04 14:45 & 2/24/04 17:00 & $2: 15$ & 2/24/04 15:52 & 109 \\
\hline TC14-11 & 2/24/04 21:30 & $2 / 25 / 041: 30$ & $4: 00$ & 2/24/04 23:30 & 117 \\
\hline TC14-12 & 2/25/04 9:00 & 2/25/04 11:30 & $2: 30$ & 2/25/04 10:15 & 127 \\
\hline TC14-13 & 2/25/04 12:15 & 2/25/04 15:30 & $3: 15$ & 2/25/04 13:52 & 131 \\
\hline TC14-14 & 2/25/04 22:30 & 2/26/04 1:30 & $3: 00$ & 2/26/04 0:00 & 141 \\
\hline TC14-15 & 2/26/04 11:15 & 2/26/04 13:15 & $2: 00$ & 2/26/04 12:15 & 153 \\
\hline TC14-16 & 2/26/04 18:00 & 2/26/04 23:15 & $5: 15$ & 2/26/04 20:37 & 162 \\
\hline TC14-17 & $2 / 27 / 044: 00$ & 2/27/04 7:00 & $3: 00$ & 2/27/04 5:30 & 170 \\
\hline TC14-18 & 2/27/04 8:00 & 2/27/04 12:00 & 4:00 & 2/27/04 10:00 & 175 \\
\hline TC14-19 & 2/27/04 17:30 & 2/27/04 21:30 & $4: 00$ & 2/27/04 19:30 & 185 \\
\hline TC14-20 & 2/28/04 1:30 & 2/28/04 6:00 & $4: 30$ & 2/28/04 3:45 & 193 \\
\hline
\end{tabular}

Notes:

1. TC14-19 and TC14-20 were oxygen blown. All others were air blown. 
Table 3.1-2 Operating Conditions

\begin{tabular}{|c|c|c|c|c|c|c|c|c|c|c|c|}
\hline $\begin{array}{c}\text { Operating } \\
\text { Periods }\end{array}$ & $\begin{array}{c}\text { Average } \\
\text { Relative } \\
\text { Hours }\end{array}$ & $\begin{array}{c}\text { Mixing Zone } \\
\text { Temperature } \\
\text { TI350 } \\
{ }^{\circ} \mathrm{F}\end{array}$ & $\begin{array}{c}\text { Pressure } \\
\text { PI287 } \\
\text { psig }\end{array}$ & $\begin{array}{c}\text { PCD Inlet } \\
\text { Temperature } \\
\text { TI458 } \\
{ }^{\circ} \mathrm{F}\end{array}$ & $\begin{array}{c}\text { Coal } \\
\text { Feed } \\
\text { Rate } \\
\text { pph }\end{array}$ & $\begin{array}{c}\text { PCD } \\
\text { Solids } \\
\text { Rate } \\
\text { pph }\end{array}$ & $\begin{array}{c}\text { Air Rate } \\
\text { lb/hr }\end{array}$ & $\begin{array}{c}\text { Oxygen } \\
\text { Rate } \\
\text { lb/hr }\end{array}$ & $\begin{array}{c}\text { Syngas } \\
\text { Rate } \\
\text { lb/hr }\end{array}$ & $\begin{array}{c}\text { Steam } \\
\text { Rate }^{3} \\
\mathrm{lb} / \mathrm{hr}\end{array}$ & $\begin{array}{c}\text { Nitrogen } \\
\text { Rate } \\
\text { lb/hr }\end{array}$ \\
\hline TC14-1 & 10 & 1,719 & 188 & 745 & 3,600 & 480 & 9,900 & 0 & 19,600 & 660 & 7,100 \\
\hline TC14-2 & 20 & 1,756 & 188 & 746 & 3,100 & 450 & 9,400 & 0 & 18,200 & 780 & 6,400 \\
\hline TC14-3 & 27 & 1,744 & 188 & 744 & 3,100 & 430 & 9,700 & 0 & 18,600 & 840 & 6,600 \\
\hline TC14-4 & 32 & 1,748 & 188 & 737 & 3,200 & 420 & 9,500 & 0 & 18,400 & 800 & 6,500 \\
\hline TC14-5 & 44 & 1,746 & 188 & 741 & 3,400 & 440 & 9,700 & 0 & 19,200 & 770 & 7,000 \\
\hline TC14-6 & 64 & 1,744 & 188 & 759 & 3,500 & 480 & 10,100 & 0 & 18,600 & 580 & 6,800 \\
\hline TC14-7 & 76 & 1,722 & 188 & 770 & 3,500 & 500 & 10,300 & 0 & 19,300 & 790 & 7,100 \\
\hline TC14-8 & 92 & 1,747 & 196 & 793 & 4,100 & 600 & 11,200 & 0 & 20,200 & 720 & 6,600 \\
\hline TC14-9 & 105 & 1,759 & 200 & 801 & 4,100 & 710 & 11,700 & 0 & 20,700 & 1,210 & 5,700 \\
\hline TC14-10 & 109 & 1,759 & 204 & 794 & 4,000 & 740 & 11,500 & 0 & 20,500 & 1,120 & 5,900 \\
\hline TC14-11 & 117 & 1,754 & 204 & 797 & 4,000 & 800 & 11,000 & 0 & 19,200 & 640 & 6,200 \\
\hline TC14-12 & 127 & 1,761 & 212 & 824 & 3,900 & 870 & 11,500 & 0 & 19,900 & 770 & 5,900 \\
\hline TC14-13 & 131 & 1,756 & 210 & 822 & 4,200 & 820 & 11,900 & 0 & 21,000 & 780 & 6,100 \\
\hline TC14-14 & 141 & 1,781 & 210 & 824 & 4,200 & 660 & 12,000 & 0 & 20,600 & 670 & 6,300 \\
\hline TC14-15 & 153 & 1,756 & 200 & 837 & 4,400 & 490 & 11,800 & 0 & 20,800 & 450 & 6,100 \\
\hline TC14-16 & 162 & 1,774 & 204 & 817 & 3,100 & 440 & 11,000 & 0 & 19,400 & 720 & 6,400 \\
\hline TC14-17 & 170 & 1,764 & 200 & 790 & 3,300 & 380 & 10,600 & 0 & 19,000 & 740 & 6,400 \\
\hline TC14-18 & 175 & 1,701 & 200 & 765 & 2,000 & 370 & 8,700 & 0 & 16,100 & 700 & 6,200 \\
\hline TC14-19 & 185 & 1,765 & 160 & 708 & 2,900 & 370 & 300 & 1,700 & 13,100 & 2,000 & 5,900 \\
\hline TC14-20 & 193 & 1,771 & 160 & 712 & 3,000 & 370 & 1,300 & 1,500 & 13,800 & 1,980 & 6,000 \\
\hline
\end{tabular}

Notes:

1. TC14-1 to TC14-18 were air blown.

2. TC14-19 and TC14-20 were oxygen blown.

3. Steam rate is by the hydrogen balance. 
Table 3.1-3 Gas Compositions, Molecular Weight, and Heating Value

\begin{tabular}{|c|c|c|c|c|c|c|c|c|c|c|c|c|c|c|}
\hline $\begin{array}{c}\text { Operating } \\
\text { Period }\end{array}$ & $\begin{array}{c}\text { Average } \\
\text { Relative } \\
\text { Hour }\end{array}$ & $\begin{array}{c}\mathrm{H}_{2} \mathrm{O}^{1} \\
\text { Mole } \\
\% \\
\end{array}$ & $\begin{array}{c}\text { CO } \\
\text { Mole } \\
\% \\
\end{array}$ & $\begin{array}{c}\mathrm{H}_{2} \\
\text { Mole } \\
\%\end{array}$ & $\begin{array}{c}\mathrm{CO}_{2} \\
\text { Mole } \\
\%\end{array}$ & $\begin{array}{c}\mathrm{CH}_{4} \\
\text { Mole } \\
\%\end{array}$ & $\begin{array}{c}\mathrm{C}_{2} \mathrm{H}_{6}{ }^{2} \\
\text { Mole } \\
\%\end{array}$ & $\begin{array}{c}\mathrm{N}_{2} \\
\text { Mole } \\
\%\end{array}$ & $\begin{array}{c}\text { Total } \\
\text { Mole } \\
\%\end{array}$ & $\begin{array}{c}\text { Syngas } \\
\text { LHV } \\
\text { Btu/SCF }\end{array}$ & $\begin{array}{c}\text { Syngas } \\
\text { TRS } \\
\text { ppm }\end{array}$ & $\begin{array}{c}\text { Syngas } \\
\text { MW } \\
\text { lb./Mole }\end{array}$ & $\begin{array}{c}\mathrm{O}_{2} \text { in } \\
\text { Feed } \\
\%\end{array}$ & $\begin{array}{c}\text { Syngas } \\
\mathrm{CO} / \mathrm{CO}_{2} \\
\text { Ratio }\end{array}$ \\
\hline TC14-1 & 10 & 9.4 & 8.0 & 6.5 & 8.8 & 1.8 & 0.0 & 65.4 & 100.0 & 60 & 239 & 26.6 & 11.3 & 0.9 \\
\hline TC14-2 & 20 & 10.5 & 7.3 & 6.4 & 9.0 & 1.5 & 0.0 & 65.3 & 100.0 & 54 & 265 & 26.6 & 11.4 & 0.8 \\
\hline TC14-3 & 27 & 11.0 & 7.1 & 6.4 & 9.0 & 1.3 & 0.0 & 65.3 & 100.0 & 52 & 303 & 26.5 & 11.4 & 0.8 \\
\hline TC14-4 & 32 & 10.8 & 7.1 & 6.4 & 9.0 & 1.4 & 0.0 & 65.2 & 100.0 & 54 & 270 & 26.5 & 11.3 & 0.8 \\
\hline TC14-5 & 44 & 10.4 & 7.1 & 6.2 & 8.9 & 1.6 & 0.0 & 65.8 & 100.0 & 55 & 278 & 26.6 & 11.2 & 0.8 \\
\hline TC14-6 & 64 & 9.7 & 7.3 & 6.2 & 8.8 & 1.7 & 0.0 & 66.3 & 100.0 & 57 & 307 & 26.6 & 11.8 & 0.8 \\
\hline TC14-7 & 76 & 10.8 & 6.4 & 6.2 & 8.9 & 1.7 & 0.0 & 66.0 & 100.0 & 53 & 328 & 26.5 & 11.4 & 0.7 \\
\hline TC14-8 & 92 & 10.8 & 7.5 & 6.8 & 9.3 & 1.9 & 0.0 & 63.8 & 100.0 & 60 & 351 & 26.4 & 12.3 & 0.8 \\
\hline TC14-9 & 105 & 12.4 & 7.3 & 7.8 & 10.0 & 1.8 & 0.0 & 60.7 & 100.0 & 61 & 302 & 26.1 & 12.5 & 0.7 \\
\hline TC14-10 & 109 & 12.1 & 7.4 & 7.5 & 9.8 & 1.8 & 0.0 & 61.4 & 100.0 & 61 & 298 & 26.2 & 12.4 & 0.7 \\
\hline TC14-11 & 117 & 10.3 & 8.1 & 7.0 & 9.2 & 2.0 & 0.0 & 63.4 & 100.0 & 63 & 337 & 26.4 & 12.5 & 0.9 \\
\hline TC14-12 & 127 & 10.5 & 8.1 & 6.9 & 9.4 & 1.9 & 0.0 & 63.3 & 100.0 & 62 & 308 & 26.4 & 12.8 & 0.9 \\
\hline TC14-13 & 131 & 10.0 & 8.3 & 7.3 & 9.4 & 2.0 & 0.0 & 63.1 & 100.0 & 65 & 183 & 26.4 & 12.8 & 0.9 \\
\hline TC14-14 & 141 & 9.9 & 8.5 & 7.1 & 9.1 & 1.9 & 0.0 & 63.5 & 100.0 & 64 & 300 & 26.4 & 12.8 & 0.9 \\
\hline TC14-15 & 153 & 9.3 & 8.5 & 6.7 & 9.4 & 2.0 & 0.0 & 64.1 & 100.0 & 64 & 222 & 26.6 & 13.1 & 0.9 \\
\hline TC14-16 & 162 & 9.6 & 7.9 & 6.2 & 8.6 & 1.2 & 0.0 & 66.5 & 100.0 & 53 & 241 & 26.7 & 12.3 & 0.9 \\
\hline TC14-17 & 170 & 10.2 & 7.2 & 6.2 & 9.1 & 1.6 & 0.0 & 65.8 & 100.0 & 55 & 233 & 26.6 & 12.1 & 0.8 \\
\hline TC14-18 & 175 & 10.3 & 5.4 & 5.0 & 8.6 & 0.7 & 0.0 & 70.0 & 100.0 & 38 & 160 & 27.0 & 11.2 & 0.6 \\
\hline "TC14-19 & 185 & 21.2 & 8.6 & 1212.0 & $\overline{c 12.5}$ & 2.0 & "0.0 & "43.8 & " 100.0 & 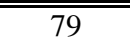 & 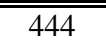 & 24.5 & 14.2 & 0.7 \\
\hline TC14-20 & 193 & 19.9 & 8.5 & 11.8 & 12.0 & 1.9 & 0.0 & 45.9 & 100.0 & 77 & 397 & 24.6 & 13.7 & 0.7 \\
\hline
\end{tabular}

1. Based on the AI475H moisture analyzer.

2. $\mathrm{C}_{2} \mathrm{H}_{6}$ content assumed to be negligible.

3. TC14-19 and TC14-20 were oxygen blown. The remainder of the test periods were air blown. 
Table 3.1-4 Syngas Sulfur and Ammonia Concentration

\begin{tabular}{|c|c|c|c|c|c|}
\hline & Average & Wet & Syngas & Wet \\
Operating & Relative & $\mathrm{H}_{2} \mathrm{~S}$ & $\begin{array}{c}\text { Tol Reduced } \\
\text { Sulfur }\end{array}$ & $\begin{array}{c}\text { Equilibrium } \\
\mathrm{H}_{2} \mathrm{~S}^{2}\end{array}$ & $\begin{array}{c}\text { AI475Q } \\
\text { Ammonia } \\
\text { Period }\end{array}$ \\
\hline TC14-1 & 10 & $\mathrm{ppm}$ & $\mathrm{ppm}$ \\
\hline TC14-2 & 20 & 115 & 216 & 201 & 1,614 \\
\hline TC14-3 & 27 & 129 & 237 & 226 & 1,359 \\
\hline TC14-4 & 32 & 193 & 270 & 236 & 1,310 \\
\hline TC14-5 & 44 & 203 & 250 & 233 & 1,377 \\
\hline TC14-6 & 64 & 219 & 277 & 223 & 1,515 \\
\hline TC14-7 & 76 & 239 & 293 & 232 & 1,644 \\
\hline TC14-8 & 92 & 246 & 313 & 235 & 1,644 \\
\hline TC14-9 & 105 & 247 & 264 & 277 & 1,724 \\
\hline TC14-10 & 109 & 262 & 262 & 269 & 1,723 \\
\hline TC14-11 & 117 & 252 & 302 & 224 & 1,832 \\
\hline TC14-12 & 127 & 259 & 276 & 230 & 1,758 \\
\hline TC14-13 & 131 & 254 & 165 & 218 & 1,665 \\
\hline TC14-14 & 141 & 249 & 270 & 214 & 1,777 \\
\hline TC14-15 & 153 & 261 & 201 & 203 & 1,684 \\
\hline TC14-16 & 162 & 270 & 218 & 204 & 1,146 \\
\hline TC14-17 & 170 & 165 & 209 & 219 & 1,445 \\
\hline TC14-18 & 175 & 216 & 143 & 217 & 718 \\
\hline \hline TC14-19 & 185 & 407 & 350 & 514 & 1,876 \\
\hline TC14-20 & 193 & 413 & 318 & 473 & 1,848 \\
\hline
\end{tabular}

Notes:

1. Syngas total reduced sulfur (TRS) estimated from syngas combustor $\mathrm{SO}_{2}$ analyzer data

2. Minimum equilibrium $\mathrm{H}_{2} \mathrm{~S}$ determined by equilibrium calculations and the carbon dioxide and water partial pressures.

3. TC14-19 and to TC14-20 were oxygen blown; The remainder were air blown. 
Table 3.1-5 Projected Syngas Compositions, Molecular Weight, and Heating Value

\begin{tabular}{|c|c|c|c|c|c|c|c|c|c|c|c|c|c|c|}
\hline $\begin{array}{c}\text { Operating } \\
\text { Period }\end{array}$ & $\begin{array}{c}\text { Average } \\
\text { Relative } \\
\text { Hour }\end{array}$ & $\begin{array}{c}\mathrm{H}_{2} \mathrm{O} \\
\text { Mole } \\
\%\end{array}$ & $\begin{array}{c}\text { CO } \\
\text { Mole } \\
\%\end{array}$ & $\begin{array}{c}\mathrm{H}_{2} \\
\text { Mole } \\
\%\end{array}$ & $\begin{array}{c}\mathrm{CO}_{2} \\
\text { Mole } \\
\%\end{array}$ & $\begin{array}{c}\mathrm{CH}_{4} \\
\text { Mole } \\
\%\end{array}$ & $\begin{array}{c}\mathrm{C}_{2} \mathrm{H}_{6} \\
\text { Mole } \\
\%\end{array}$ & $\begin{array}{c}\mathrm{N}_{2} \\
\text { Mole } \\
\%\end{array}$ & $\begin{array}{c}\text { Total } \\
\text { Mole } \\
\%\end{array}$ & $\begin{array}{c}\text { Syngas } \\
\text { LHV } \\
\text { Btu/SCF }\end{array}$ & $\begin{array}{c}\text { Syngas } \\
\text { MW } \\
\text { lb./Mole }\end{array}$ & $\begin{array}{l}\mathrm{O}_{2} \text { in } \\
\text { Feed } \\
\%\end{array}$ & $\begin{array}{c}\text { Syngas } \\
\mathrm{CO} / \mathrm{CO}_{2} \\
\text { Ratio }\end{array}$ & $\begin{array}{c}\text { Cold Syngas } \\
\text { LHV } \\
\text { Btu/SCF }\end{array}$ \\
\hline TC14-1 & 10 & 16.4 & 17.0 & 13.7 & 10.1 & 3.9 & 0.0 & 38.9 & 100.0 & 127 & 24.0 & 16.5 & 1.7 & 151 \\
\hline TC14-2 & 20 & 18.3 & 15.3 & 13.4 & 10.2 & 3.1 & 0.0 & 39.7 & 100.0 & 114 & 23.9 & 15.9 & 1.5 & 139 \\
\hline TC14-3 & 27 & 19.1 & 14.6 & 13.3 & 10.3 & 2.7 & 0.0 & 40.0 & 100.0 & 108 & 24.0 & 15.8 & 1.4 & 133 \\
\hline TC14-4 & 32 & 18.9 & 14.8 & 13.4 & 10.4 & 3.0 & 0.0 & 39.4 & 100.0 & 112 & 23.9 & 15.8 & 1.4 & 137 \\
\hline TC14-5 & 44 & 18.5 & 15.2 & 13.3 & 10.3 & 3.4 & 0.0 & 39.3 & 100.0 & 117 & 23.9 & 15.9 & 1.5 & 142 \\
\hline TC14-6 & 64 & 16.4 & 15.0 & 12.7 & 9.6 & 3.5 & 0.0 & 42.8 & 100.0 & 115 & 24.2 & 17.1 & 1.6 & 137 \\
\hline TC14-7 & 76 & 18.6 & 13.1 & 12.6 & 10.1 & 3.4 & 0.0 & 42.1 & 100.0 & 108 & 24.1 & 16.3 & 1.3 & 131 \\
\hline TC14-8 & 92 & 17.2 & 13.7 & 12.5 & 10.3 & 3.4 & 0.0 & 42.9 & 100.0 & 109 & 24.3 & 17.2 & 1.3 & 131 \\
\hline TC14-9 & 105 & 18.6 & 12.2 & 13.0 & 11.1 & 3.0 & 0.0 & 42.1 & 100.0 & 102 & 24.2 & 16.0 & 1.1 & 124 \\
\hline TC14-10 & 109 & 18.5 & 12.6 & 12.8 & 10.9 & 3.2 & 0.0 & 42.1 & 100.0 & 105 & 24.2 & 16.1 & 1.2 & 127 \\
\hline TC14-11 & 117 & 15.9 & 14.3 & 12.4 & 9.9 & 3.5 & 0.0 & 43.9 & 100.0 & 112 & 24.3 & 17.5 & 1.5 & 132 \\
\hline TC14-12 & 127 & 16.0 & 14.0 & 11.9 & 10.1 & 3.3 & 0.0 & 44.7 & 100.0 & 108 & 24.5 & 17.2 & 1.4 & 127 \\
\hline TC14-13 & 131 & 15.3 & 14.5 & 12.6 & 10.3 & 3.4 & 0.0 & 43.7 & 100.0 & 113 & 24.4 & 17.3 & 1.4 & 132 \\
\hline TC14-14 & 141 & 15.0 & 14.7 & 12.2 & 9.7 & 3.3 & 0.0 & 45.1 & 100.0 & 111 & 24.5 & 17.7 & 1.5 & 129 \\
\hline TC14-15 & 153 & 14.4 & 15.1 & 11.9 & 10.4 & 3.5 & 0.0 & 44.7 & 100.0 & 113 & 24.7 & 18.3 & 1.5 & 131 \\
\hline TC14-16 & 162 & 15.6 & 15.1 & 11.9 & 9.2 & 2.2 & 0.0 & 45.9 & 100.0 & 102 & 24.5 & 17.1 & 1.6 & 120 \\
\hline TC14-17 & 170 & 16.7 & 14.1 & 12.0 & 10.0 & 3.1 & 0.0 & 44.1 & 100.0 & 106 & 24.4 & 16.8 & 1.4 & 127 \\
\hline TC14-18 & 175 & 19.3 & 12.9 & 11.9 & 9.3 & 1.7 & 0.0 & 44.9 & 100.0 & 90 & 24.3 & 15.8 & 1.4 & 110 \\
\hline TC14-19² & 185 & 24.3 & 22.3 & $\begin{array}{l}31.0 \\
\end{array}$ & 17.2 & 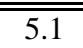 & $\overline{0.0}$ & $\overline{00.0}$ & "100.0 & 204 & $\bar{~} 19.6$ & 29.7 & $\bar{~} 1.3$ & 267 \\
\hline TC14-20 & 193 & 22.5 & 23.0 & 31.8 & 17.5 & 5.1 & 0.0 & 0.0 & 100.0 & 208 & 19.7 & 27.7 & 1.3 & 266 \\
\hline
\end{tabular}

Notes:

1. Commercially projected values based on using recycle gas and assuming an adiabatic gasifier.

2. TC14-19 and TC14-20 were oxygen blown. The remainder were air blown. 
Table 3.1-6 Coal Analysis

\begin{tabular}{|c|c|c|}
\hline & \multicolumn{2}{|c|}{ Powder River Basin } \\
\hline & $\begin{array}{c}\text { Average } \\
\text { Value }^{1}\end{array}$ & $\begin{array}{l}\text { Standard } \\
\text { Deviation }\end{array}$ \\
\hline Moisture, wt\% & 21.18 & 0.72 \\
\hline Carbon, wt\% & 55.23 & 0.78 \\
\hline Hydrogen $^{2}$, wt\% & 3.65 & 0.21 \\
\hline Nitrogen, wt $\%$ & 0.73 & 0.01 \\
\hline Oxygen, wt\% & 14.05 & 0.74 \\
\hline Sulfur ${ }^{3}$, wt $\%$ & 0.26 & 0.02 \\
\hline Ash, wt\% & 4.89 & 0.47 \\
\hline Volatiles, wt\% & 34.67 & 0.13 \\
\hline Fixed Carbon, wt\% & 39.26 & 0.73 \\
\hline Higher Heating Value, Btu/lb & 9,341 & 99 \\
\hline Lower Heating Value, Btu/lb & 9,002 & 94 \\
\hline $\mathrm{CaO}$, wt \% & 0.80 & 0.02 \\
\hline $\mathrm{SiO}_{2}$, wt \% & 1.63 & 0.16 \\
\hline $\mathrm{Al}_{2} \mathrm{O}_{3}, \mathrm{wt} \%$ & 0.79 & 0.05 \\
\hline $\mathrm{MgO}$, wt $\%$ & 0.29 & 0.01 \\
\hline $\mathrm{Na}$, wt \% in ash & 1.38 & 0.36 \\
\hline $\mathrm{Ca} / \mathrm{S}$, mole/mole & 2.51 & 0.16 \\
\hline
\end{tabular}

Notes:

1. All analyses are as sampled at FD0210.

2. Hydrogen in coal is reported separately from hydrogen in moisture.

3. Sulfur Sample AB14535 was omitted due to sampling error. 
Table 3.1-7 Standpipe Solids Analysis

\begin{tabular}{|c|c|c|c|c|c|c|c|c|c|c|c|c|}
\hline $\begin{array}{l}\text { Sample } \\
\text { Number }\end{array}$ & $\begin{array}{c}\text { Sample } \\
\text { Date \& Time }\end{array}$ & $\begin{array}{c}\text { Sample } \\
\text { Run Time } \\
\text { Hours }\end{array}$ & $\begin{array}{c}\mathrm{SiO}_{2} \\
\text { Wt. \% }\end{array}$ & $\begin{array}{l}\mathrm{Al}_{2} \mathrm{O}_{3} \\
\text { Wt. \% }\end{array}$ & $\begin{array}{c}\mathrm{FeO} \\
\text { Wt. \% }\end{array}$ & $\begin{array}{l}\text { Other } \\
\text { Inerts } \\
\text { Wt. \% }\end{array}$ & $\begin{array}{c}\mathrm{CaCO}_{3}{ }^{2} \\
\text { Wt. \% }\end{array}$ & $\begin{array}{c}\text { CaS } \\
\text { Wt. \% }\end{array}$ & $\begin{array}{l}\mathrm{CaO}^{2} \\
\text { Wt. \% }\end{array}$ & $\begin{array}{c}\text { MgO } \\
\text { Wt. \% }\end{array}$ & $\begin{array}{c}\text { Organic } \\
\text { Carbon }^{2} \\
\text { Wt. \% }\end{array}$ & $\begin{array}{l}\text { Total } \\
\text { Wt. \% }\end{array}$ \\
\hline AB14447 & 2/20/2004 18:00 & 15 & 87.7 & 2.7 & 1.2 & 1.5 & 1.4 & 0.0 & 3.0 & 0.9 & 0.2 & 98.6 \\
\hline AB14449 & 2/21/2004 11:00 & 32 & 86.6 & 3.3 & 1.6 & 1.4 & 1.4 & 0.0 & 4.0 & 1.1 & 0.3 & 99.7 \\
\hline AB14451 & 2/22/2004 2:00 & 47 & 86.1 & 4.1 & 0.6 & 1.9 & 1.4 & 0.0 & 4.2 & 1.1 & 0.0 & 99.5 \\
\hline AB14453 & $2 / 22 / 200418: 00$ & 63 & 87.4 & 3.2 & 1.3 & 1.8 & 1.4 & 0.0 & 3.8 & 1.1 & 0.1 & 99.9 \\
\hline AB14456 & $2 / 23 / 2004$ 10:00 & 79 & 86.2 & 3.6 & 1.2 & 2.0 & 1.4 & 0.0 & 2.2 & 0.7 & 0.8 & 98.3 \\
\hline AB14477 & 2/24/2004 2:00 & 95 & 88.1 & 3.2 & 1.1 & 1.7 & 1.5 & 0.0 & 2.6 & 0.7 & 0.2 & 99.1 \\
\hline AB14490 & $2 / 24 / 2004$ 18:00 & 111 & 89.2 & 3.1 & 1.1 & 1.7 & 1.5 & 0.0 & 2.4 & 0.7 & 0.3 & 100.2 \\
\hline AB14501 & $2 / 25 / 2004$ 10:00 & 127 & 84.6 & 3.4 & 1.1 & 1.6 & 1.5 & 0.0 & 2.8 & 1.0 & 0.6 & 96.5 \\
\hline AB14510 & 2/26/2004 2:00 & 143 & 83.9 & 3.1 & 1.0 & 1.8 & 1.3 & 0.1 & 2.8 & 0.8 & 3.0 & 97.9 \\
\hline AB14522 & $2 / 26 / 2004$ 10:00 & 151 & 88.3 & 2.9 & 1.1 & 1.8 & 1.3 & 0.0 & 3.0 & 0.8 & 0.6 & 99.8 \\
\hline AB14540 & 2/27/2004 10:00 & 175 & 88.3 & 2.9 & 1.2 & 2.2 & 1.3 & 0.0 & 2.4 & 0.7 & 0.3 & 99.3 \\
\hline AB14552 & $2 / 27 / 2004$ 18:00 & 183 & 89.1 & 3.3 & 1.2 & 1.7 & 1.3 & 0.0 & 2.7 & 0.8 & 2.0 & 102.1 \\
\hline AB14554 & 2/28/2004 10:00 & 199 & 86.9 & 3.4 & 1.4 & 1.8 & 1.3 & 0.0 & 4.3 & 1.2 & 0.2 & 100.3 \\
\hline
\end{tabular}

Notes:

1. Other inerts consist of $\mathrm{BaO}, \mathrm{P}_{2} \mathrm{O}_{5}, \mathrm{Na}_{2} \mathrm{O}, \mathrm{K}_{2} \mathrm{O}$, \& $\mathrm{TiO}_{2}$.

2. $\mathrm{CaCO}_{3}$, organic carbon, and $\mathrm{CaO}$ contents based on $\mathrm{CO}_{2}$ measured. $\mathrm{CO}_{2}$ only measured for samples $\mathrm{AB} 14453, \mathrm{AB} 14490, \mathrm{AB} 14522$, and $\mathrm{AB} 14554 . \mathrm{CO}_{2}$ interpolated for all other samples. 
Table 3.1-8 Loop Seal Solids Analysis

\begin{tabular}{|c|c|c|c|c|c|c|c|c|c|c|c|c|}
\hline $\begin{array}{l}\text { Sample } \\
\text { Number }\end{array}$ & $\begin{array}{c}\text { Sample } \\
\text { Date \& Time }\end{array}$ & \begin{tabular}{|c|} 
Sample \\
Run Time \\
Hours \\
\end{tabular} & $\begin{array}{c}\mathrm{SiO}_{2} \\
\text { Wt. \% }\end{array}$ & $\begin{array}{l}\mathrm{Al}_{2} \mathrm{O}_{3} \\
\text { Wt. \% }\end{array}$ & $\begin{array}{c}\text { FeO } \\
\text { Wt. \% }\end{array}$ & $\begin{array}{l}\text { Other } \\
\text { Inerts }^{1} \\
\text { Wt. \% }\end{array}$ & $\begin{array}{l}\mathrm{CaCO}_{3} \\
\text { Wt. \% }\end{array}$ & $\begin{array}{c}\mathrm{CaS} \\
\text { Wt. \% }\end{array}$ & $\begin{array}{c}\mathrm{CaO} \\
\text { Wt. \% }\end{array}$ & $\begin{array}{l}\text { MgO } \\
\text { Wt. \% }\end{array}$ & $\begin{array}{c}\text { Organic } \\
\text { Carbon } \\
\text { Wt. \% }\end{array}$ & $\begin{array}{r}\text { Total } \\
\text { Wt. \% }\end{array}$ \\
\hline AB14405 & $2 / 20 / 200414: 00$ & 11 & 84.4 & 4.7 & 1.5 & 1.9 & 1.8 & 0.0 & 3.9 & 1.2 & 8.0 & 107.4 \\
\hline AB14440 & $2 / 21 / 2004$ 10:00 & 31 & 81.2 & 6.5 & 1.6 & 2.6 & 1.7 & 0.0 & 4.5 & 1.3 & 6.6 & 106.1 \\
\hline AB14442 & $2 / 21 / 200418: 00$ & 39 & 83.6 & 5.3 & 1.5 & 2.3 & 2.3 & 0.0 & 3.7 & 1.1 & 4.3 & 104.1 \\
\hline AB14444 & $2 / 22 / 200418: 00$ & 63 & 83.7 & 5.6 & 1.4 & 2.3 & 2.8 & 0.0 & 2.7 & 1.0 & 12.1 & 111.5 \\
\hline AB14445 & $2 / 23 / 2004$ 2:00 & 71 & 83.6 & 5.9 & 1.4 & 2.2 & 2.3 & 0.0 & 2.9 & 0.9 & 5.6 & 104.8 \\
\hline AB14499 & $2 / 25 / 2004$ 10:00 & 127 & 84.5 & 5.5 & 1.2 & 2.3 & 3.1 & 0.0 & 2.1 & 0.9 & 8.2 & 107.9 \\
\hline AB14520 & $2 / 26 / 2004$ 10:00 & 151 & 88.0 & 4.1 & 0.9 & 2.2 & 3.6 & 0.0 & 1.3 & 0.8 & 7.6 & 108.4 \\
\hline AB14541 & $2 / 27 / 2004$ 10:00 & 175 & 88.0 & 4.0 & 0.9 & 2.2 & 3.6 & 0.0 & 1.1 & 0.7 & 4.2 & 104.7 \\
\hline AB14551 & $2 / 28 / 2004$ 10:00 & 199 & 81.5 & 6.3 & 1.3 & 2.8 & 4.6 & 0.0 & 2.5 & 1.2 & 7.1 & 107.3 \\
\hline
\end{tabular}

Notes:

1. Other inerts consist of $\mathrm{BaO}, \mathrm{P}_{2} \mathrm{O}_{5}, \mathrm{Na}_{2} \mathrm{O}, \mathrm{K}_{2} \mathrm{O}, \& \mathrm{TiO}_{2}$. 
Table 3.1-9 PCD Solids from FD0520 and FD0540 Analysis

\begin{tabular}{|c|c|c|c|c|c|c|c|c|c|c|c|c|c|c|}
\hline $\begin{array}{c}\text { Sample } \\
\text { Number }^{2}\end{array}$ & $\begin{array}{c}\text { Sample } \\
\text { Date \& Time }\end{array}$ & $\begin{array}{c}\text { Sample } \\
\text { Run Time } \\
\text { Hours } \\
\end{array}$ & $\begin{array}{c}\mathrm{SiO}_{2} \\
\text { Wt. \% }\end{array}$ & $\begin{array}{l}\mathrm{Al}_{2} \mathrm{O}_{3} \\
\text { Wt. \% }\end{array}$ & $\begin{array}{c}\mathrm{FeO} \\
\text { Wt. \% }\end{array}$ & $\begin{array}{l}\text { Other } \\
\text { Inerts }^{1} \\
\text { Wt. \% }\end{array}$ & $\begin{array}{l}\mathrm{CaCO}_{3} \\
\text { Wt. \% }\end{array}$ & $\begin{array}{c}\mathrm{CaS} \\
\text { Wt. \% }\end{array}$ & $\begin{array}{r}\mathrm{CaO} \\
\text { Wt. \% }\end{array}$ & $\begin{array}{l}\text { MgO } \\
\text { Wt. \% }\end{array}$ & $\begin{array}{c}\text { Organic C } \\
\left(\mathrm{C}-\mathrm{CO}_{2}\right) \\
\text { Wt. \% }\end{array}$ & $\begin{array}{r}\text { Total } \\
\text { Wt. \% }\end{array}$ & $\begin{array}{l}\text { HHV } \\
\text { Btu/lb. }\end{array}$ & $\begin{array}{c}\text { LHV } \\
\text { Btu/lb. }\end{array}$ \\
\hline AB14398 & 2/20/2004 6:00 & 3 & 87.7 & 3.0 & 0.9 & 2.7 & 2.9 & 0.1 & 0.0 & 0.6 & 2.7 & 100.6 & 8,655 & 8,654 \\
\hline AB14404 & $2 / 20 / 200414: 00$ & 11 & 54.6 & 5.5 & 1.5 & 2.7 & 7.8 & 0.3 & 0.2 & 1.3 & 42.7 & 116.7 & 4,247 & 4,207 \\
\hline AB14429 & $2 / 20 / 200418: 00$ & 15 & 75.9 & 4.4 & 1.4 & 2.3 & 4.3 & 0.2 & 2.0 & 1.2 & 30.8 & 122.4 & 6,204 & 6,179 \\
\hline AB14431 & $2 / 21 / 20042: 00$ & 23 & 60.3 & 6.8 & 2.5 & 2.8 & 4.8 & 0.3 & 4.8 & 2.0 & 27.1 & 111.4 & 2,107 & 2,081 \\
\hline AB14432 & $2 / 21 / 200414: 00$ & 35 & 47.9 & 6.7 & 2.0 & 2.8 & 6.8 & 0.4 & 3.1 & 1.9 & 29.7 & 101.3 & 4,458 & 4,425 \\
\hline AB14433 & 2/21/2004 18:00 & 39 & 66.5 & 6.0 & 1.8 & 2.5 & 5.2 & 0.2 & 3.1 & 1.5 & 20.9 & 107.5 & 1,264 & 1,251 \\
\hline AB14436 & $2 / 22 / 200422: 00$ & 67 & 32.8 & 7.8 & 2.2 & 2.4 & 7.0 & 0.6 & 3.8 & 2.0 & 43.7 & 102.2 & 6,337 & 6,295 \\
\hline AB14472 & 2/23/2004 18:00 & 87 & 38.5 & 6.4 & 1.8 & 2.3 & 8.8 & 0.4 & 1.7 & 1.7 & 43.4 & 104.9 & 5,880 & 5,842 \\
\hline AB14482 & $2 / 24 / 200414: 00$ & 107 & 43.2 & 6.5 & 1.9 & 2.6 & 2.7 & 0.3 & 6.2 & 1.9 & 47.8 & 113.0 & 5,450 & 5,404 \\
\hline AB14492 & 2/24/2004 18:00 & 111 & 57.5 & 5.5 & 1.3 & 2.5 & 4.3 & 0.2 & 2.9 & 1.3 & 33.4 & 108.9 & 3,494 & 3,461 \\
\hline AB14493 & $2 / 24 / 200422: 00$ & 115 & 26.6 & 6.3 & 1.8 & 2.4 & 5.2 & 0.3 & 4.7 & 2.1 & 51.2 & 100.7 & 7,313 & 7,254 \\
\hline AB14494 & $2 / 25 / 20042: 00$ & 119 & 38.9 & 5.6 & 1.5 & 2.4 & 6.3 & 0.3 & 2.6 & 1.6 & 44.3 & 103.4 & 6,072 & 6,022 \\
\hline AB14500 & 2/25/2004 10:00 & 127 & 21.1 & 5.7 & 1.6 & 2.0 & 5.3 & 0.4 & 3.7 & 1.8 & 58.4 & 100.1 & 8,355 & 8,276 \\
\hline AB14504 & 2/25/2004 14:00 & 131 & 29.2 & 5.6 & 1.5 & 2.1 & 4.9 & 0.3 & 3.6 & 1.8 & 55.3 & 104.4 & 7,735 & 7,670 \\
\hline AB14512 & $2 / 26 / 20042: 00$ & 143 & 56.9 & 5.0 & 1.4 & 2.5 & 3.5 & 0.2 & 3.6 & 1.4 & 48.4 & 122.8 & 3,847 & 3,800 \\
\hline AB14528 & $2 / 26 / 200414: 00$ & 155 & 29.9 & 6.4 & 1.9 & 2.6 & 4.2 & 0.4 & 5.3 & 2.1 & 55.5 & 108.3 & 7,089 & 7,026 \\
\hline AB14531 & 2/26/2004 22:00 & 163 & 53.2 & 7.4 & 2.1 & 3.3 & 4.1 & 0.4 & 6.0 & 2.3 & 25.2 & 104.0 & 3,126 & 3,104 \\
\hline AB14533 & $2 / 27 / 2004$ 6:00 & 171 & 39.9 & 7.1 & 2.3 & 3.2 & 7.3 & 0.4 & 3.7 & 2.1 & 43.4 & 109.4 & 5,254 & 5,209 \\
\hline AB14543 & $2 / 27 / 200414: 00$ & 179 & 63.9 & 8.2 & 2.4 & 4.5 & 3.0 & 0.1 & 8.9 & 2.4 & 9.8 & 103.2 & - & - \\
\hline AB14556 & $2 / 27 / 200422: 00$ & 187 & 35.6 & 7.3 & 2.2 & 2.8 & 4.5 & 0.1 & 7.7 & 2.5 & 41.2 & 104.0 & 5,520 & 5,489 \\
\hline AB14558 & 2/28/2004 6:00 & 195 & 29.5 & 7.9 & 2.7 & 2.9 & 5.6 & 0.1 & 9.2 & 3.0 & 40.3 & 101.4 & 5,764 & 5,726 \\
\hline AB14560 & 2/28/2004 14:00 & 203 & 79.3 & 5.4 & 1.2 & 3.0 & 3.3 & 0.1 & 2.8 & 1.2 & 3.4 & 99.7 & 347 & 346 \\
\hline
\end{tabular}

Notes:

1. Other inerts consist of $\mathrm{P}_{2} \mathrm{O}_{5}, \mathrm{Na}_{2} \mathrm{O}, \mathrm{K}_{2} \mathrm{O}$, \& $\mathrm{TiO}_{2}$.

2. Samples AB14398, AB14429 and AB14431 came from FD0520, the remainder from FD0540. 
Table 3.1-10 Historical As-Fed Coal Particle Sizes and Percent Fines Oversize

\begin{tabular}{|c|c|c|c|c|c|c|c|c|c|c|}
\hline \multirow{5}{*}{$\begin{array}{l}\text { Test } \\
\text { Campaign }\end{array}$} & \multirow[b]{5}{*}{ Fuel } & \multirow{5}{*}{$\begin{array}{c}\text { Time Range } \\
\text { Run Hours }\end{array}$} & \multirow{5}{*}{$\begin{array}{l}\text { Average } \\
\text { Feed } \\
\text { Coal } \\
\text { SMD } \\
\text { microns }\end{array}$} & \multirow{5}{*}{$\begin{array}{l}\text { Std. Dev. } \\
\text { Feed } \\
\text { Coal } \\
\text { SMD } \\
\text { microns }\end{array}$} & \multirow{5}{*}{$\begin{array}{l}\text { Average } \\
\text { Feed } \\
\text { Coal } \\
\text { MMD } \\
\text { microns }\end{array}$} & \multirow{5}{*}{$\begin{array}{l}\text { Std. Dev. } \\
\text { Feed } \\
\text { Coal } \\
\text { MMD } \\
\text { microns }\end{array}$} & Average & Std. Dev. & Average & Std. Dev. \\
\hline & & & & & & & Feed & Feed & Feed & Feed \\
\hline & & & & & & & Coal & Coal & Coal & Coal \\
\hline & & & & & & & $\%>1180$ & $\%>1180$ & $\%<45$ & $\%<45$ \\
\hline & & & & & & & microns & microns & microns & microns \\
\hline TC06 & Powder River Basin & all & 188 & 43 & 277 & 52 & 0.1 & 0.1 & 11.8 & 7.1 \\
\hline $\mathrm{TCO}^{1}$ & Powder River Basin & 2 to 80 & 221 & 40 & 293 & 35 & 5.8 & 1.5 & 6.6 & 3.1 \\
\hline TC07 & Alabama Bituminous & 100 to 132 & 201 & 14 & 290 & 15 & 8.5 & 3.0 & 8.1 & 1.1 \\
\hline${\mathrm{TC} 07^{2}}^{2}$ & Powder River Basin & 162 to 142 & 197 & 17 & 289 & 21 & 0.1 & 0.3 & 8.8 & 1.9 \\
\hline TC08 & Powder River Basin & בall & 195 & 15 & 282 & 18 & 0.1 & 0.1 & 8.7 & 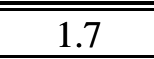 \\
\hline TC09 & Hiawatha Bituminous & all & 232 & 13 & 297 & 36 & 0.3 & 0.1 & 4.6 & 1.3 \\
\hline TC10 & Powder River Basin & 0 to 90 & 231 & 10 & 299 & 15 & 0.2 & 0.2 & 4.4 .4 & 0.4 \\
\hline $\mathrm{TC}^{3} 0^{3}$ & Powder River Basin & 131 to 412 & 239 & 24 & 376 & 69 & 11.1 & 4.8 & 6.5 & 2.8 \\
\hline${\mathrm{TC} 11^{4}}^{4}$ & Falkirk Lignite & all & 165 & 28 & 283 & 40 & 10.0 & 3.1 & 14.2 & 3.8 \\
\hline TC12 & Powder River Basin & 0 to 467 & 313 & 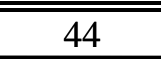 & 479 & 135 & 14.6 & 7.6 & 3.5 & 1.9 \\
\hline $\mathrm{TC}_{12}{ }^{5}$ & Powder River Basin & 517 to 733 & 175 & 37 & 265 & 56 & 5.6 & 2.0 & 12.5 & 5.8 \\
\hline TC13 & Powder River Basin & 0 to 121 & 195 & 50 & 262 & 71 & 4.3 & 1.9 & 9.4 & 5.0 \\
\hline TC13 & Freedom Lignite & 129 to 504 & 227 & 28 & 435 & 81 & 11.6 & 4.8 & 8.6 & 2.4 \\
\hline TC14 & Powder River Basin & all & 246 & 37 & 418 & 74 & 10.3 & 3.5 & 7.0 & 2.7 \\
\hline
\end{tabular}

Notes

1. 1000 micron screen was removed from mill prior to start of TC07.

2. 1000 micron screen was installed on mill between TC07 hours 132 and 162.

3. 1000 micron screen was removed from mill on 11/23/02 (TC10 hour 90).

4. 2800 micron screen was installed in mill prior to start of TC11.

5. As received PRB was very wet prior to hour 4/3/03 (TC12 hour 467). On 4/3/03 several loads of dry coal were received. 
Table 3.1-11 Historical Standpipe and PCD Fines

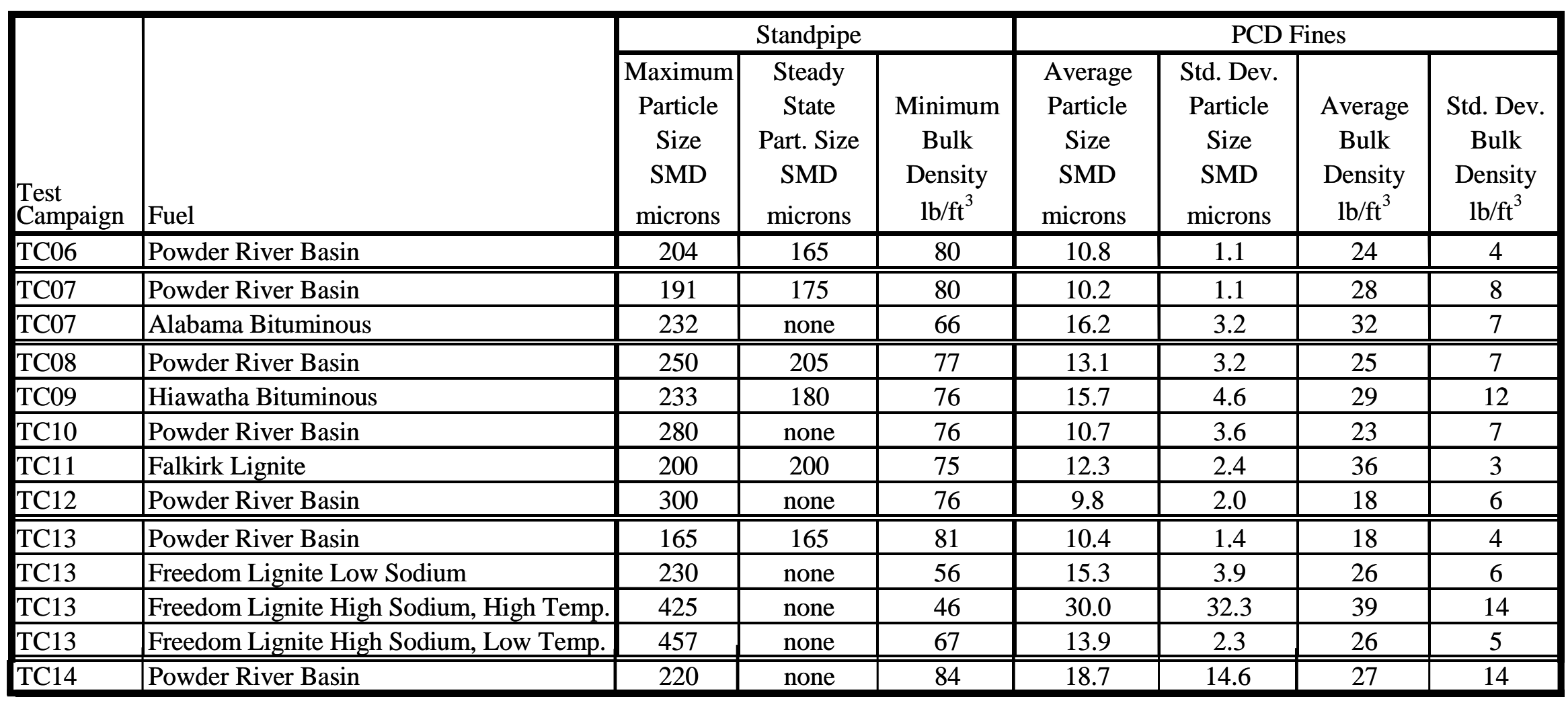


Table 3.1-12 Carbon Conversion

\begin{tabular}{|c|c||c|c|c|}
\hline & $\begin{array}{c}\text { Average } \\
\text { Operating } \\
\text { Period }\end{array}$ & $\begin{array}{c}\text { Gas } \\
\text { Carbon } \\
\text { Conversion } \\
\text { Hours }\end{array}$ & $\begin{array}{c}\text { Solids } \\
\text { Carbon } \\
\text { Conversion } \\
\%\end{array}$ & $\begin{array}{c}\text { Products } \\
\text { Carbon } \\
\text { Conversion } \\
\%\end{array}$ \\
\hline TC14-1 & 10 & 83.0 & 89.1 & 89.1 \\
\hline TC14-2 & 20 & 85.8 & 91.8 & 91.8 \\
\hline TC14-3 & 27 & 85.9 & 92.5 & 92.5 \\
\hline TC14-4 & 32 & 85.1 & 92.4 & 92.4 \\
\hline TC14-5 & 44 & 82.9 & 93.2 & 93.2 \\
\hline TC14-6 & 64 & 78.2 & 88.4 & 88.4 \\
\hline TC14-7 & 76 & 77.5 & 87.2 & 87.2 \\
\hline TC14-8 & 92 & 74.9 & 86.4 & 86.4 \\
\hline TC14-9 & 105 & 80.9 & 84.4 & 84.4 \\
\hline TC14-10 & 109 & 79.8 & 85.7 & 85.7 \\
\hline TC14-11 & 117 & 75.6 & 81.3 & 81.3 \\
\hline TC14-12 & 127 & 80.0 & 77.7 & 77.7 \\
\hline TC14-13 & 131 & 80.8 & 80.6 & 80.6 \\
\hline TC14-14 & 141 & 79.2 & 84.9 & 84.9 \\
\hline TC14-15 & 153 & 77.4 & 87.4 & 87.4 \\
\hline TC14-16 & 162 & 91.3 & 91.7 & 91.7 \\
\hline TC14-17 & 170 & 85.2 & 90.6 & 90.6 \\
\hline TC14-18 & 175 & 93.9 & 87.1 & 87.1 \\
\hline \hline TC14-19 & 185 & 92.1 & 90.7 & 90.7 \\
\hline TC14-20 & 193 & 90.5 & 91.1 & 91.1 \\
\hline \hline
\end{tabular}

Notes:

1. TC14-1 to TC14-18 were air blown; TC14-19 and TC14-20 were oxygen blown. 
Table 3.1-13 Gasification Efficiencies

\begin{tabular}{|c|c|c|c|c|}
\hline \multirow{4}{*}{$\begin{array}{c}\text { Operating } \\
\text { Period }^{1}\end{array}$} & \multirow{4}{*}{$\begin{array}{c}\text { Average } \\
\text { Relative } \\
\text { Hours }\end{array}$} & \multicolumn{3}{|c|}{ Efficiency } \\
\hline & & \multicolumn{2}{|c|}{ Raw } & \multirow{3}{*}{$\begin{array}{c}\text { Projected }^{2} \\
\text { Cold } \\
\%\end{array}$} \\
\hline & & Cold & Hot & \\
\hline & & $\%$ & $\%$ & \\
\hline TC14-1 & 10 & 53.4 & 81.0 & 71.0 \\
\hline TC14-2 & 20 & 50.7 & 80.4 & 69.5 \\
\hline TC14-3 & 27 & 50.9 & 82.1 & 70.5 \\
\hline TC14-4 & 32 & 50.6 & 81.1 & 69.9 \\
\hline TC14-5 & 44 & 52.9 & 83.4 & 72.8 \\
\hline TC14-6 & 64 & 50.5 & 78.2 & 67.4 \\
\hline TC14-7 & 76 & 48.8 & 77.3 & 65.5 \\
\hline TC14-8 & 92 & 51.5 & 78.5 & 65.9 \\
\hline TC14-9 & 105 & 51.3 & 78.5 & 64.2 \\
\hline TC14-10 & 109 & 52.3 & 79.5 & 65.8 \\
\hline TC14-11 & 117 & 49.3 & 73.7 & 61.7 \\
\hline TC14-12 & 127 & 46.8 & 71.1 & 58.2 \\
\hline TC14-13 & 131 & 49.8 & 74.3 & 61.5 \\
\hline TC14-14 & 141 & 54.1 & 80.9 & 67.9 \\
\hline TC14-15 & 153 & 53.5 & 80.3 & 67.7 \\
\hline TC14-16 & 162 & 50.4 & 81.2 & 67.9 \\
\hline TC14-17 & 170 & 51.2 & 80.7 & 68.7 \\
\hline TC14-18 & 175 & 40.0 & 73.9 & 61.6 \\
\hline "TC14-19 & 185 & 56.3 & 80.0 & 76.4 \\
\hline TC14-20 & 193 & 56.6 & 80.2 & 76.8 \\
\hline
\end{tabular}

Notes:

1. TC14-1 to TC14-18 were air blown; TC14-19 and TC14-20 were oxygen blown.

2. Commercially projected values based on using recycle gas and assuming an adiabatic gasifier. 


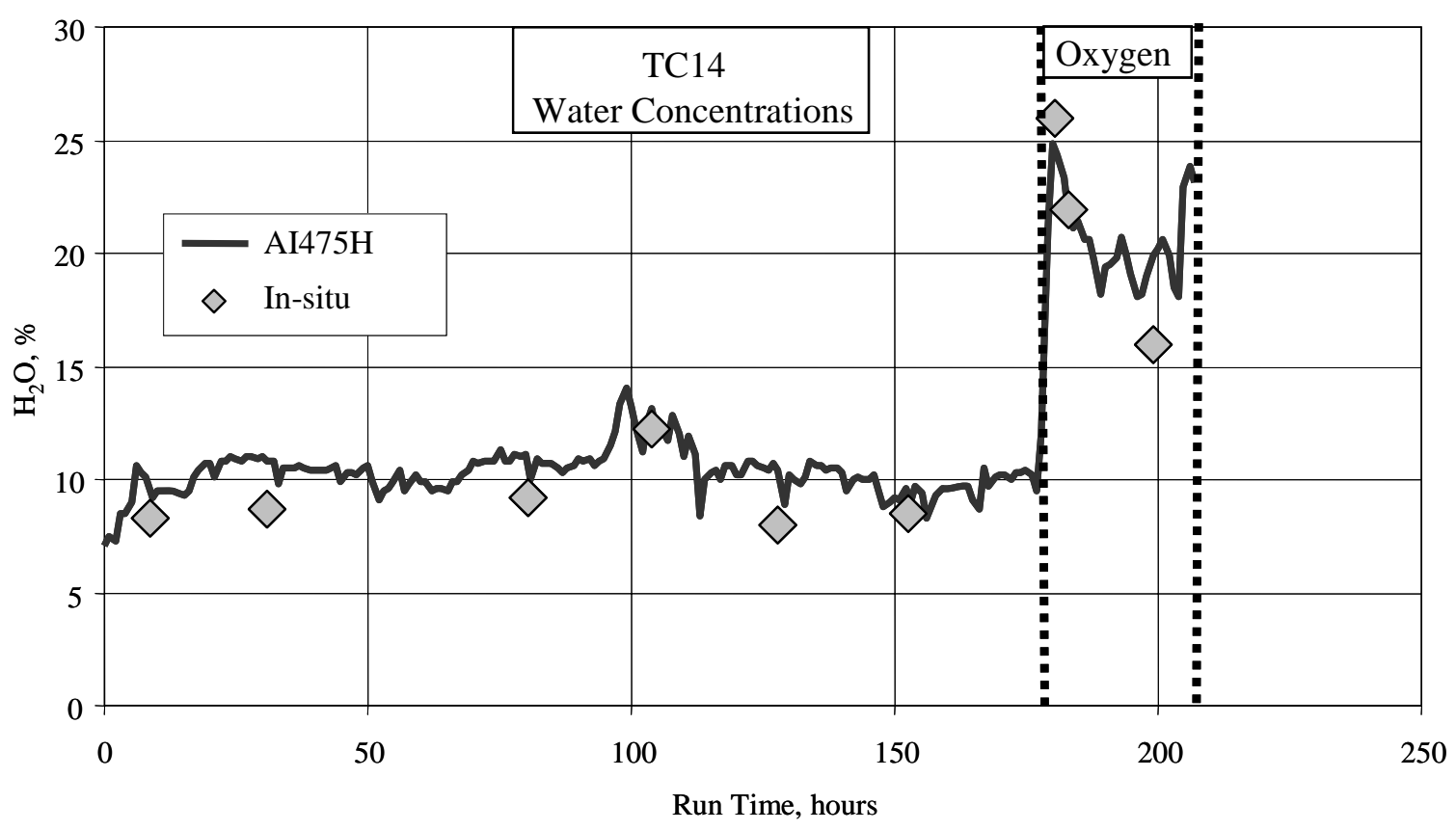

Figure 3.1-1 $\mathrm{H}_{2} \mathrm{O}$ Data

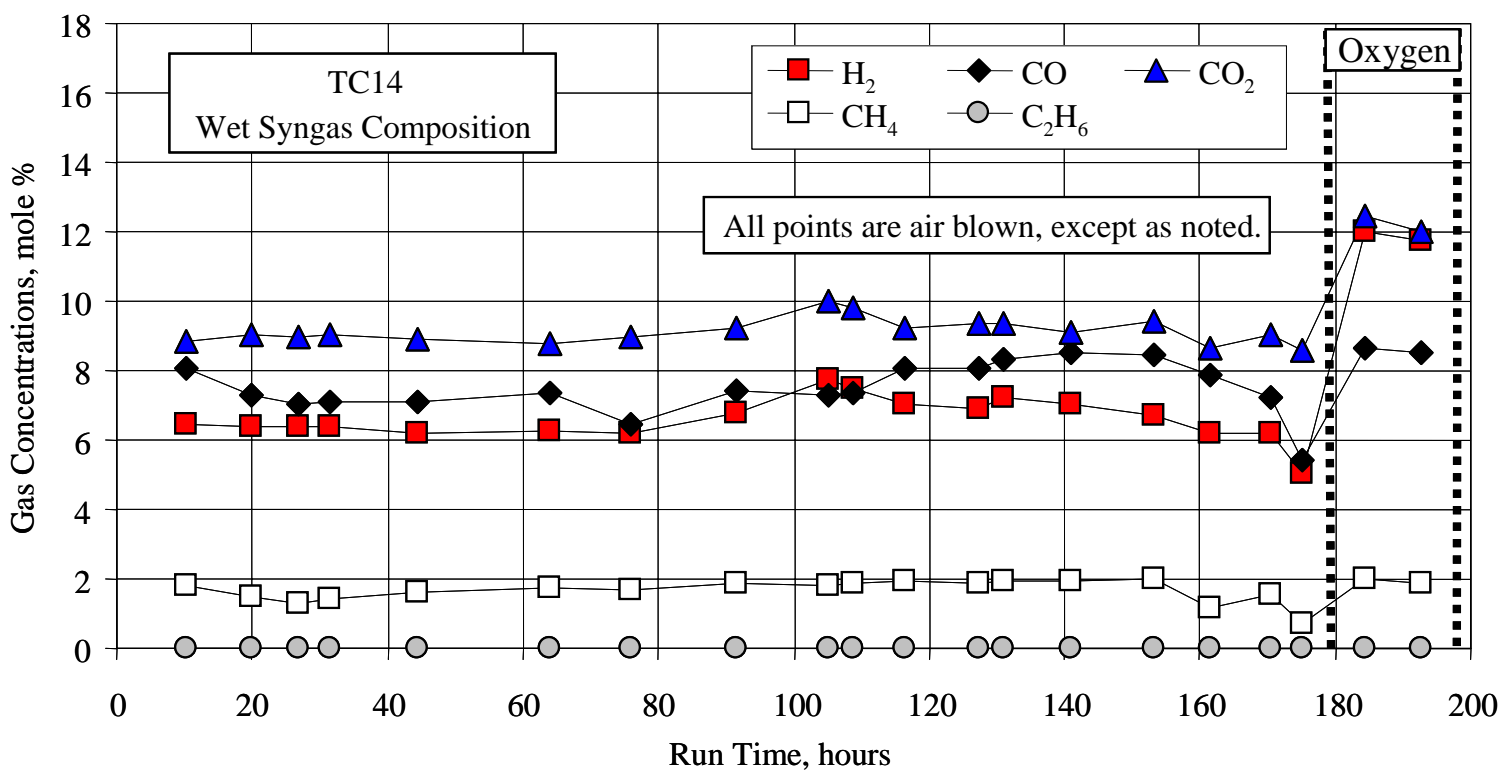

Figure 3.1-2 Wet Syngas Compositions 


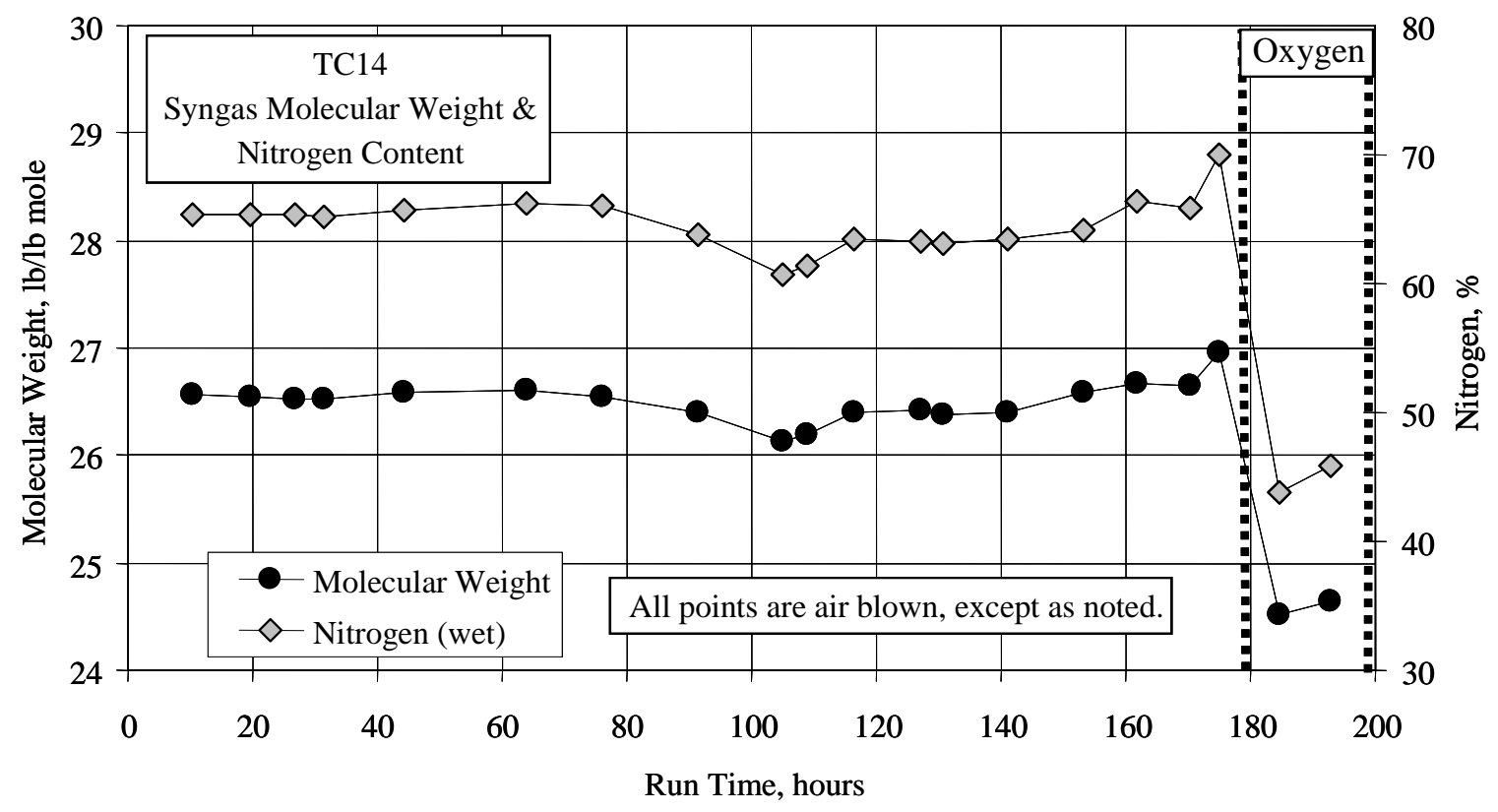

Figure 3.1-3 Syngas Molecular Weight \& Nitrogen Concentration

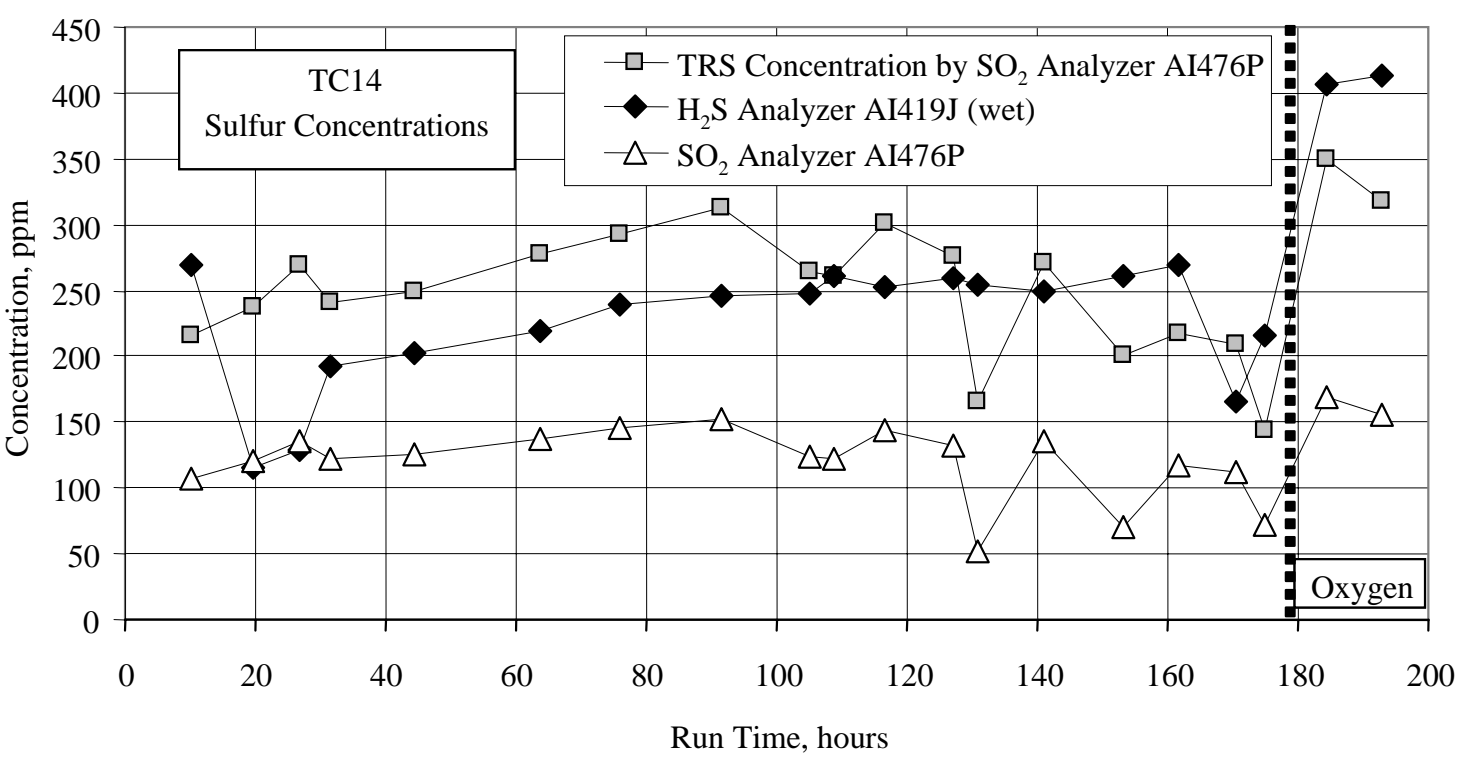

Figure 3.1-4 Sulfur Concentrations 


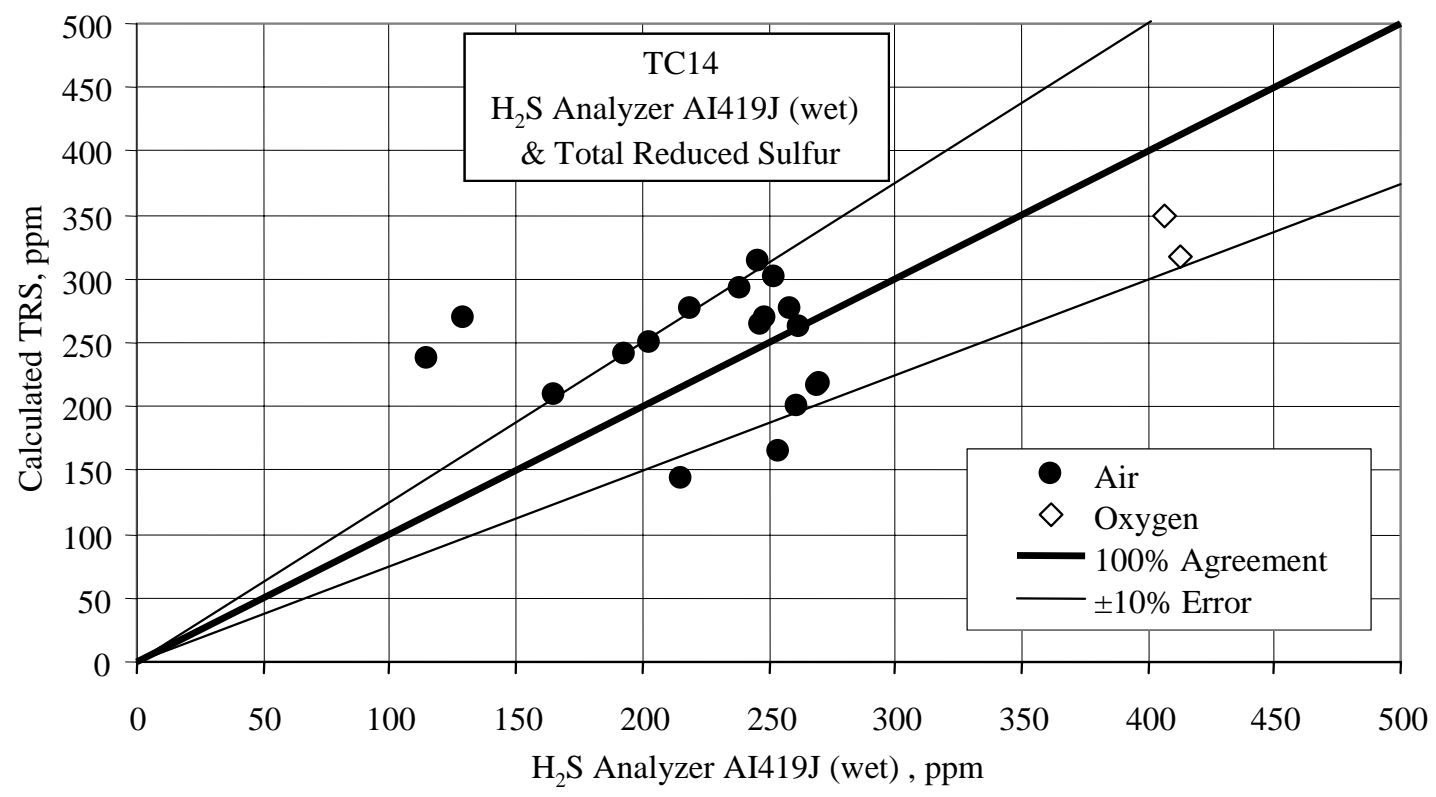

Figure 3.1-5 $\mathrm{H}_{2} \mathrm{~S}$ Analyzer Al419J \& Total Reduced Sulfur

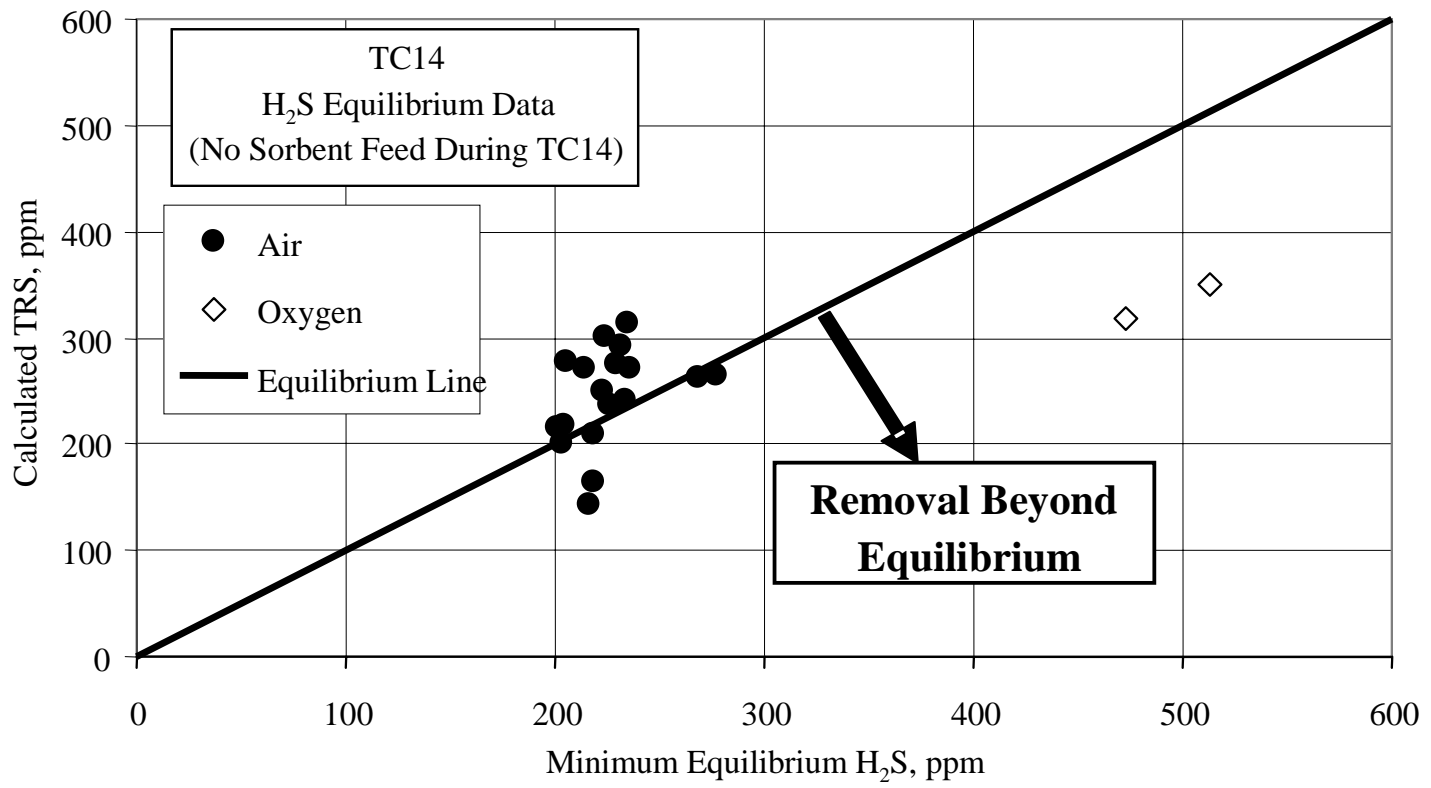

Figure 3.1-6 Minimum Equilibrium $\mathrm{H}_{2} \mathrm{~S}$ \& Total Reduced Sulfur 


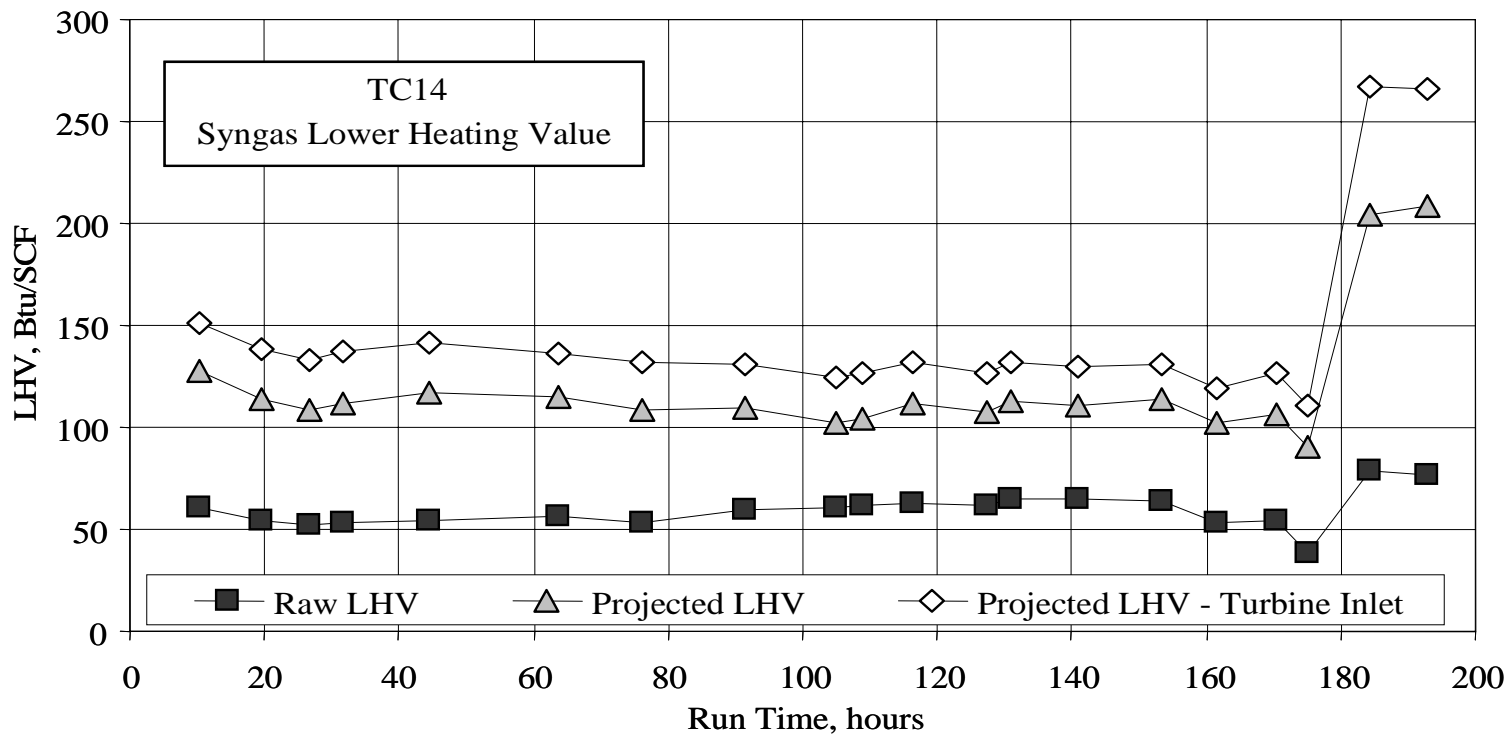

Figure 3.1-7 Syngas Lower Heating Values

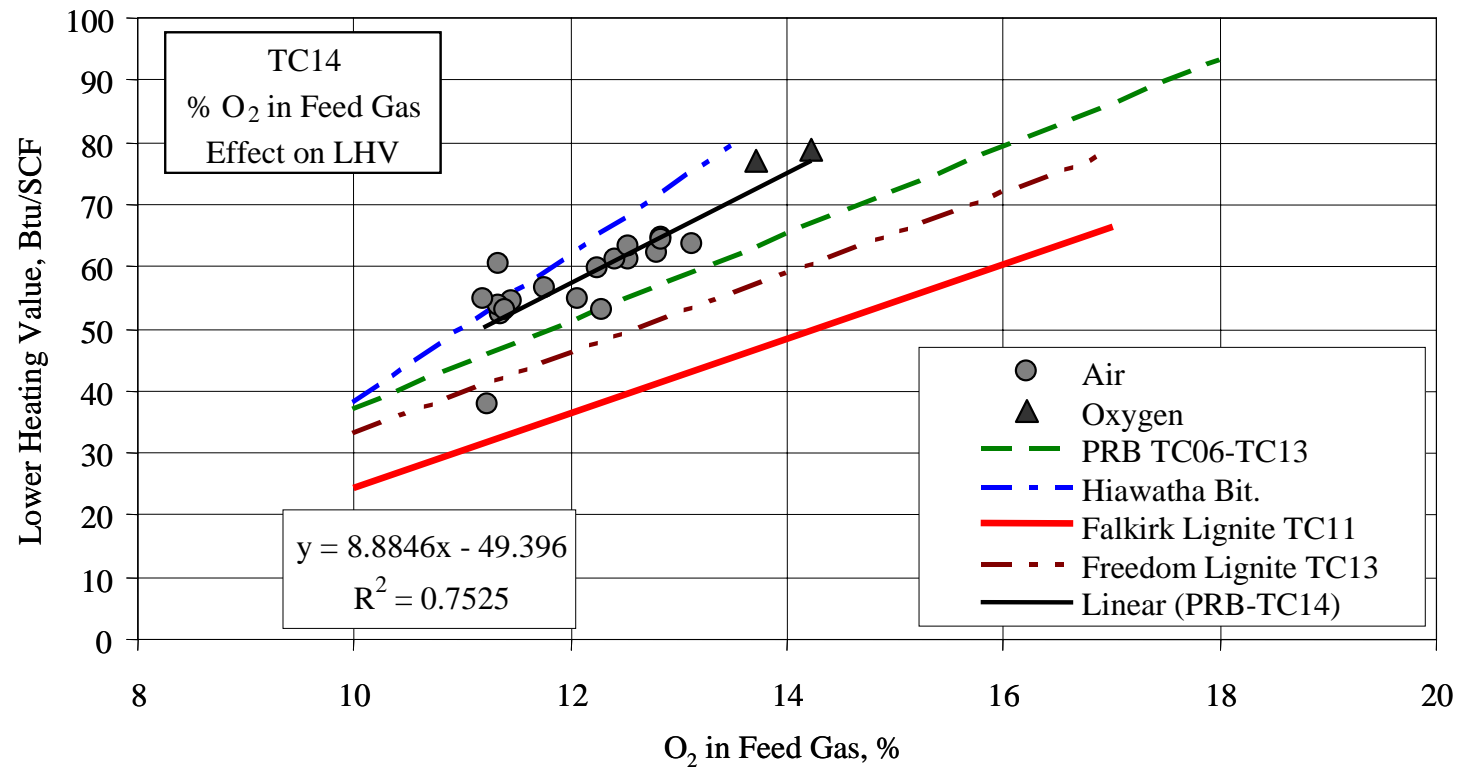

Figure 3.1-8 Raw Lower Heating Value \& Overall $\% \mathrm{O}_{2}$ 


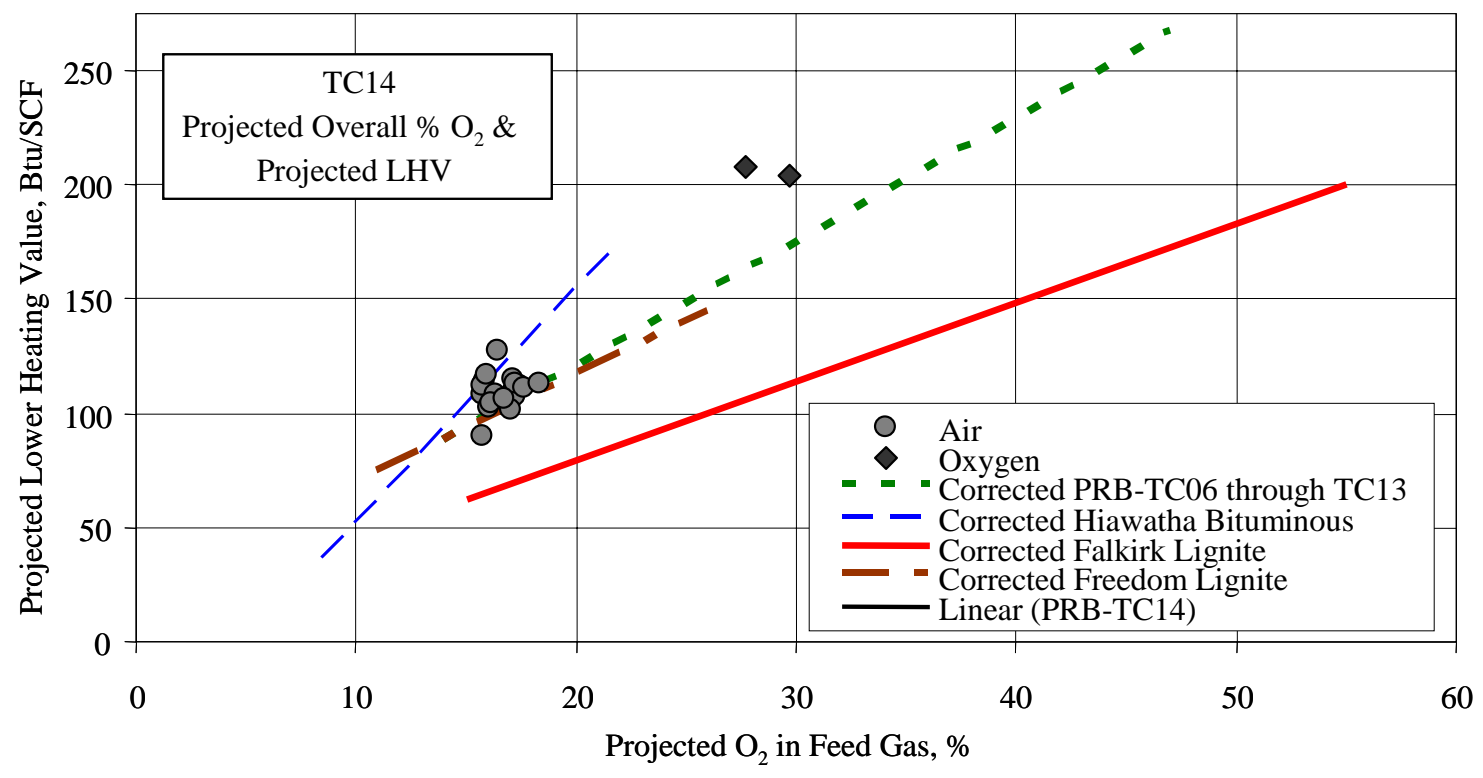

Figure 3.1-9 Projected LHV \& Projected Overall $\% \mathrm{O}_{2}$

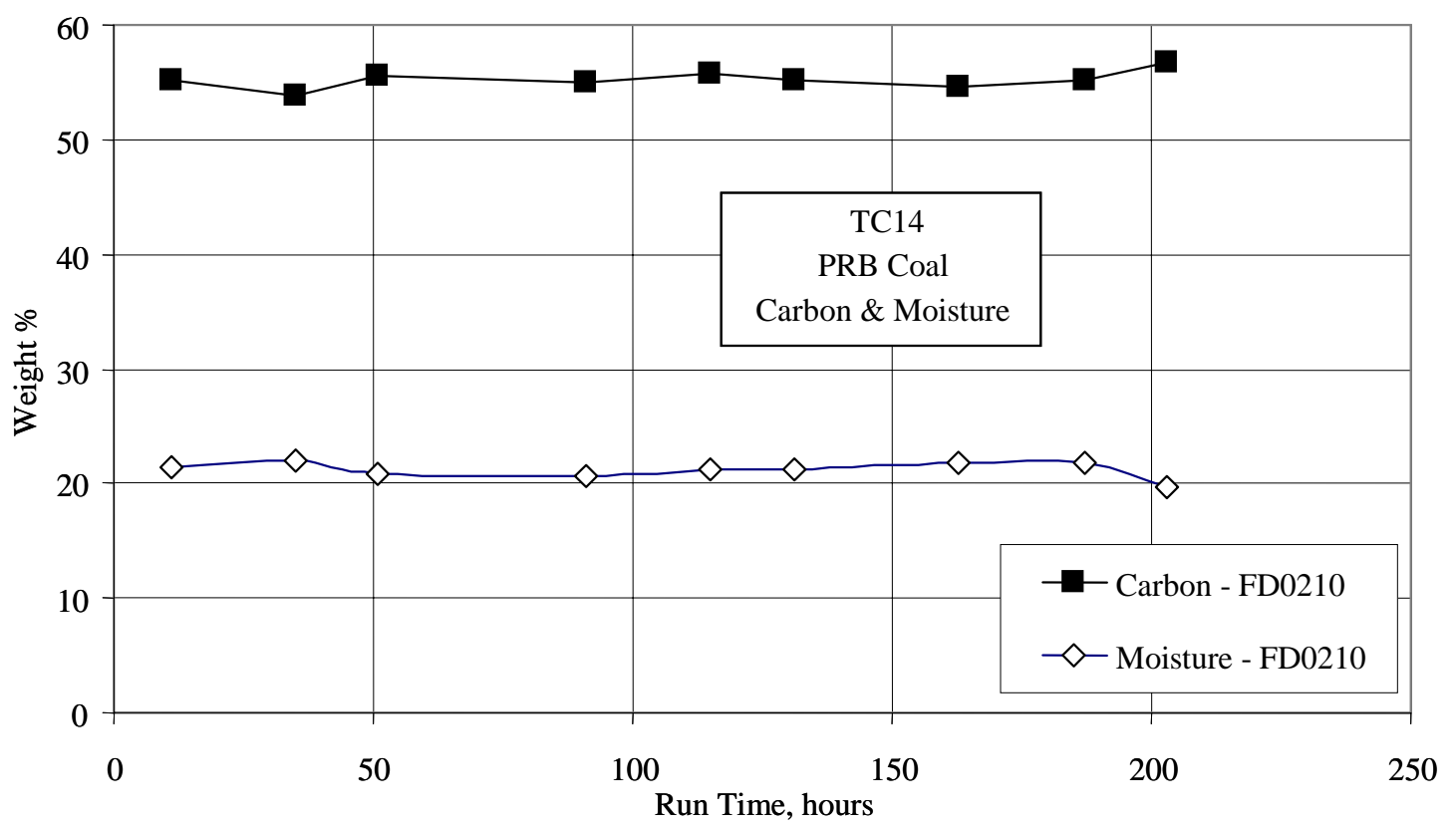

Figure 3.1-10 Coal Carbon \& Moisture 


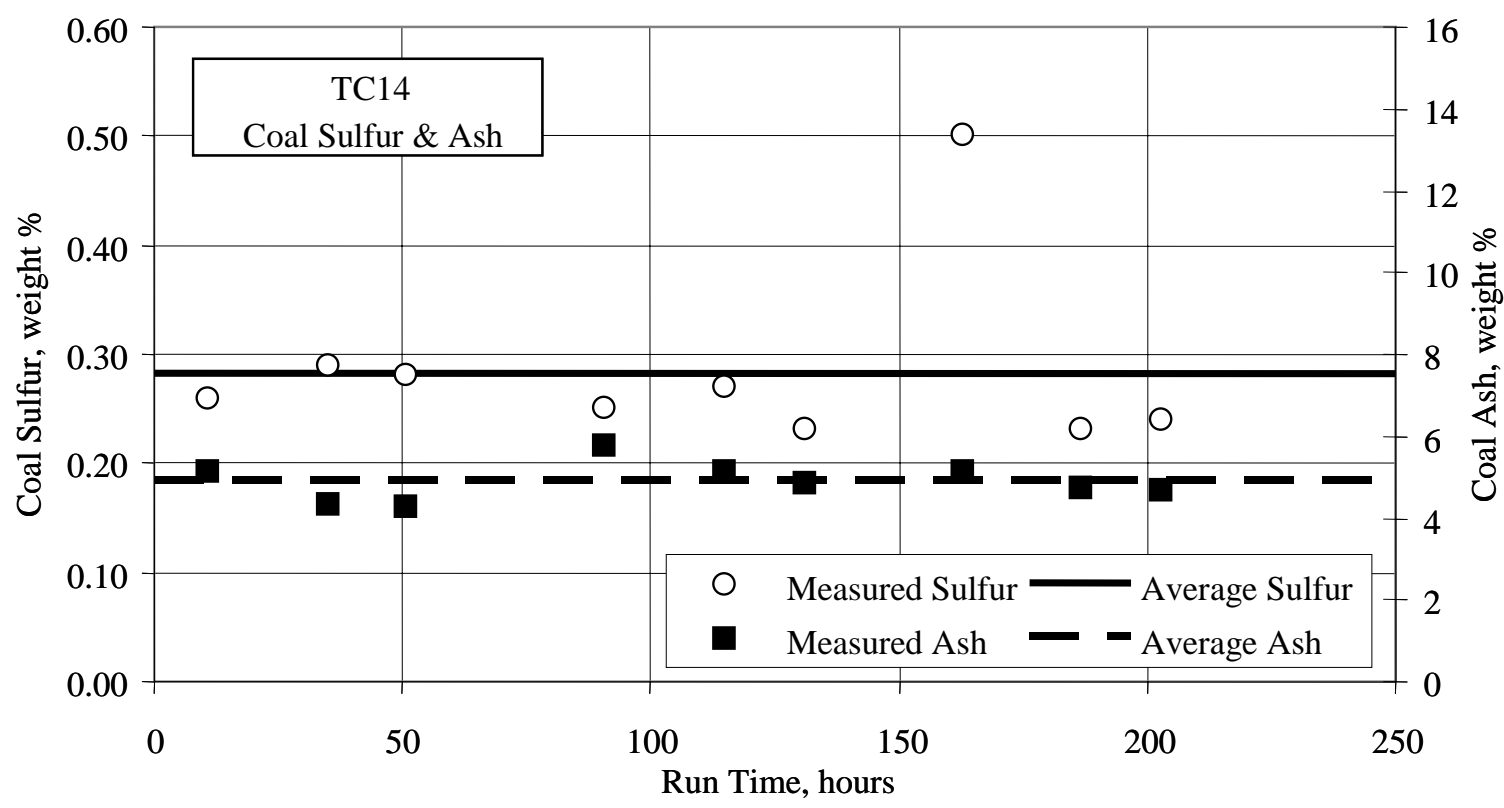

Figure 3.1-11 Coal Sulfur \& Ash

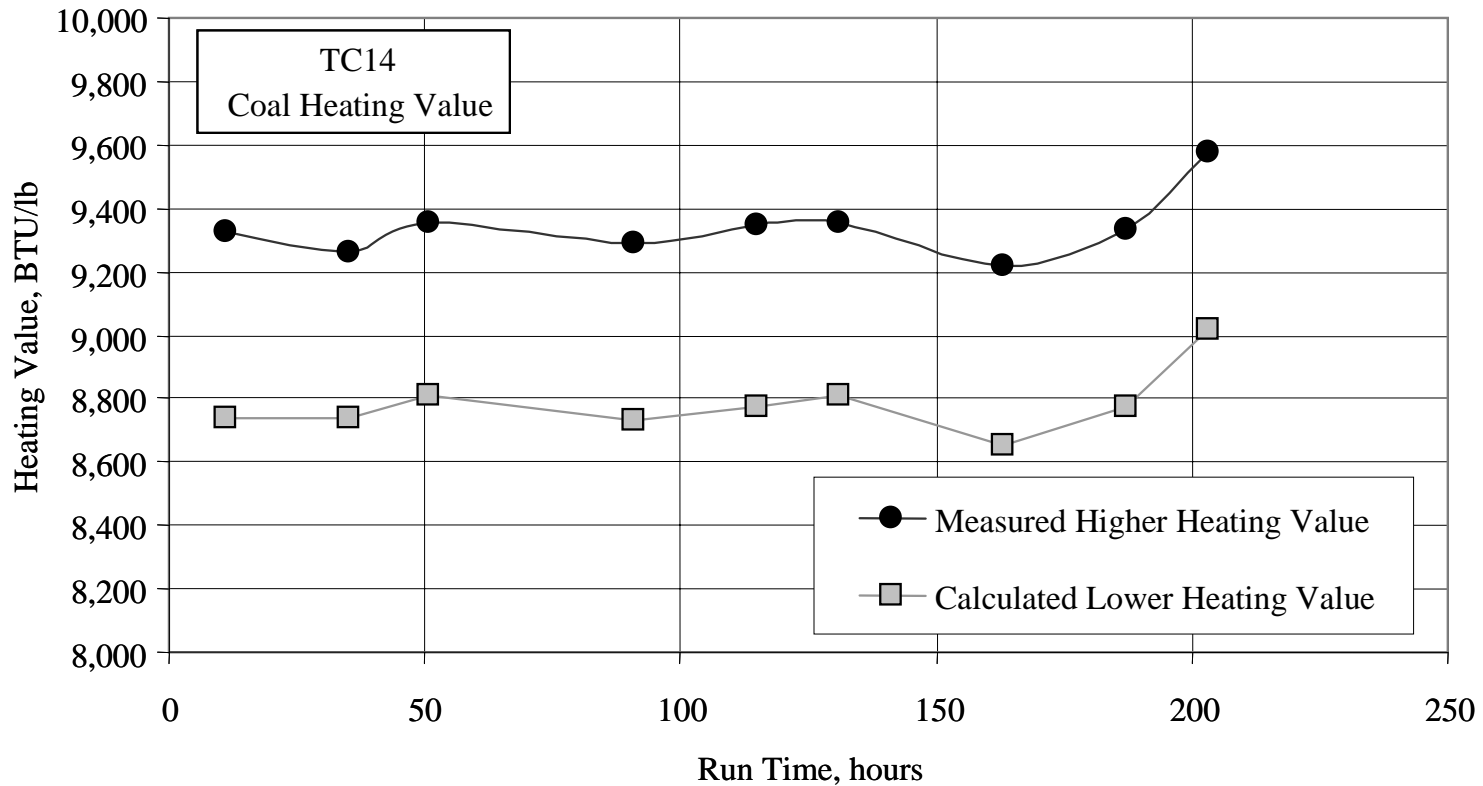

Figure 3.1-12 Coal Heating Value 


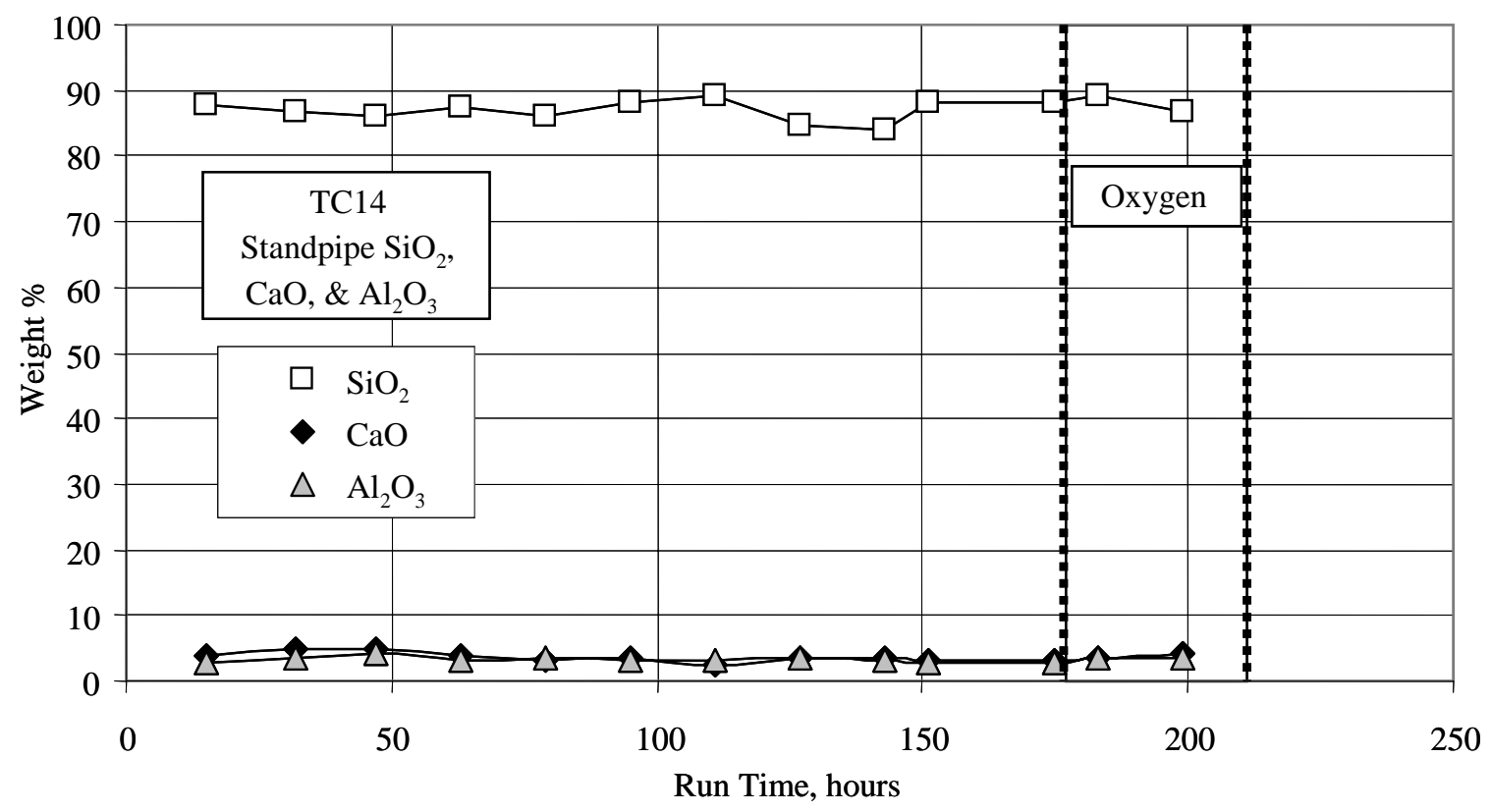

Figure 3.1-13 Gasifier $\mathrm{SiO}_{2}, \mathrm{CaO}, \& \mathrm{Al}_{2} \mathrm{O}_{3}$

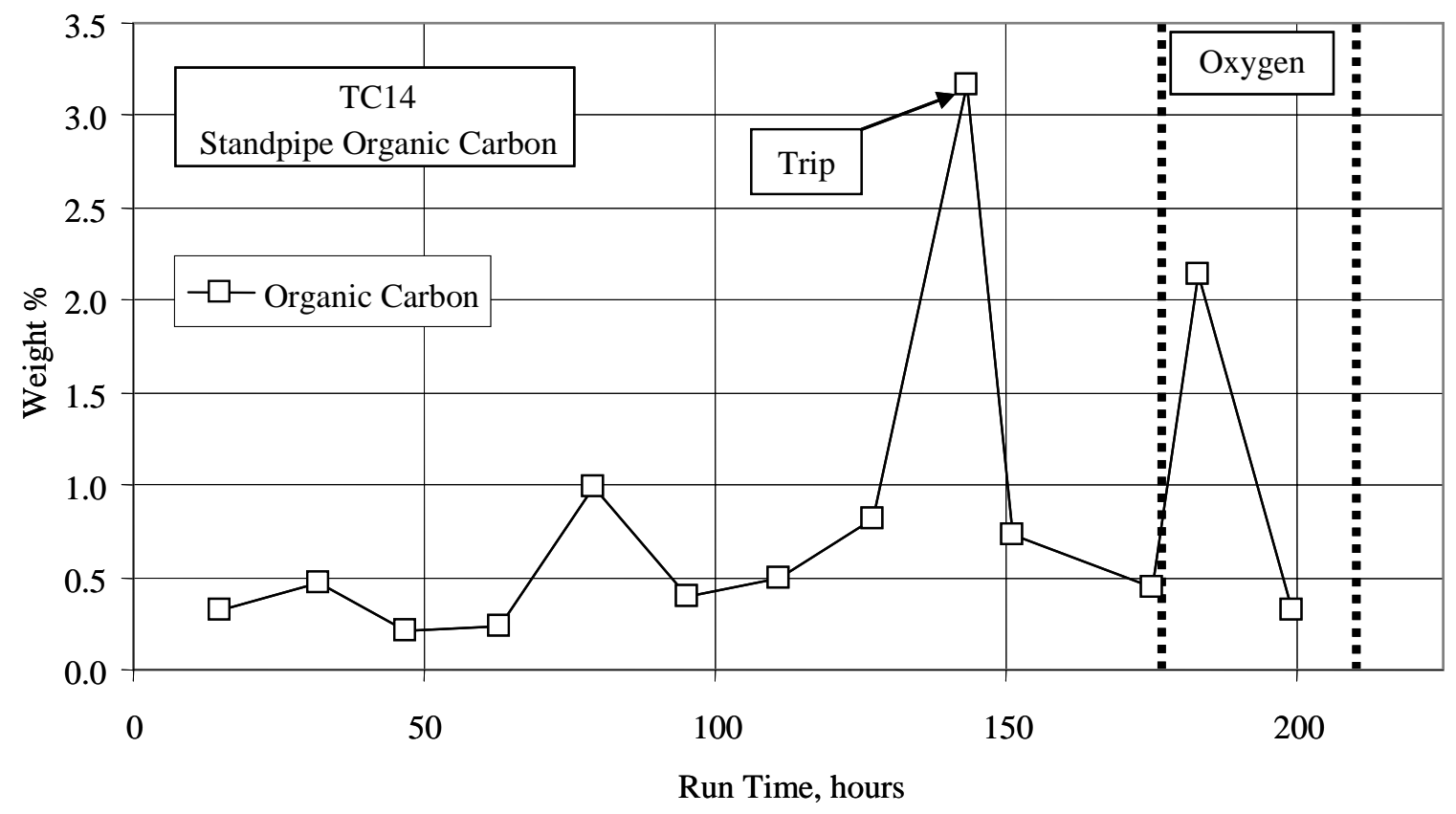

Figure 3.1-14 Gasifier Organic Carbon 


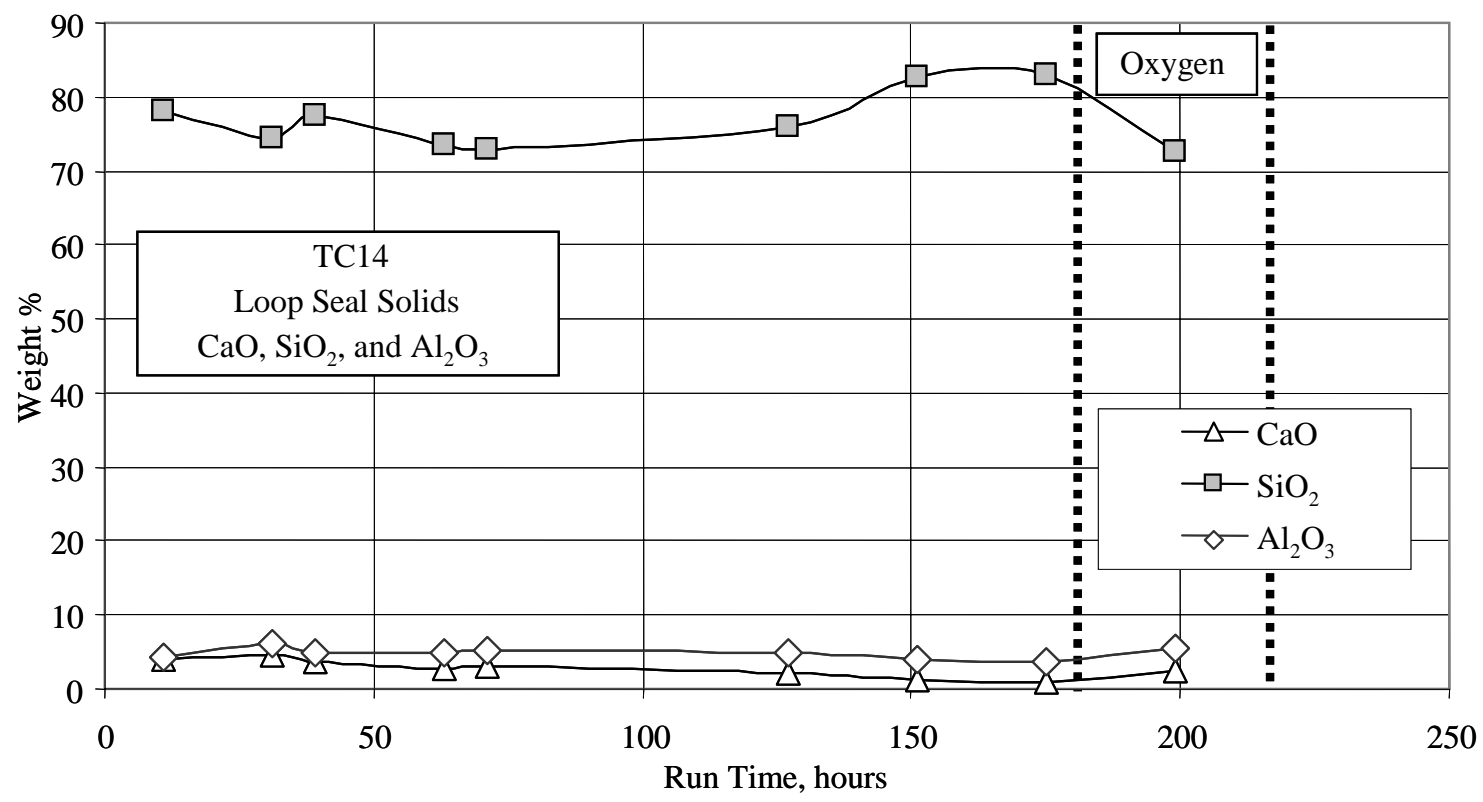

Figure 3.1-15 Loop Seal Solids $\mathrm{SiO}_{2}, \mathrm{CaO}, \& \mathrm{Al}_{2} \mathrm{O}_{3}$

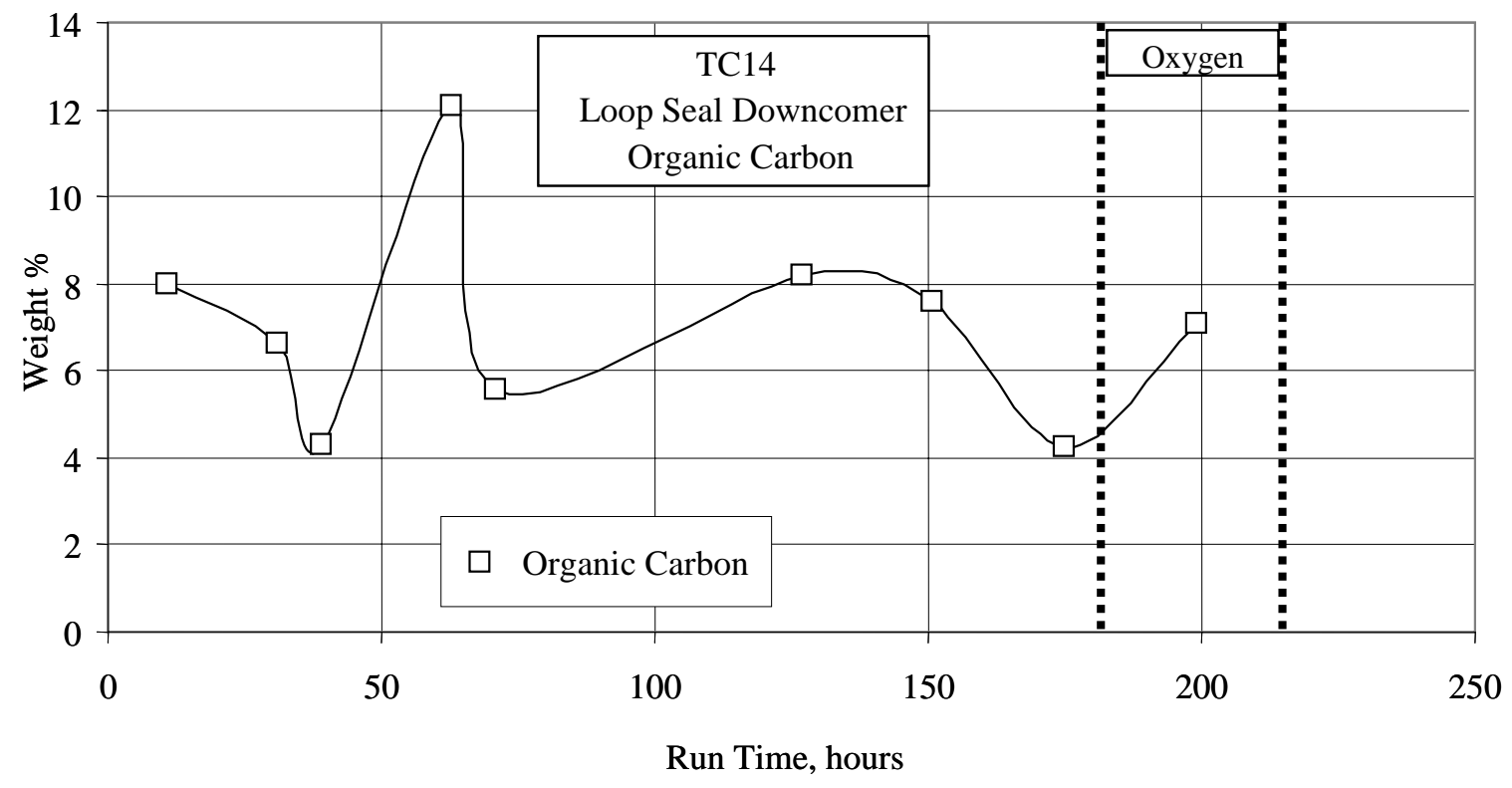

Figure 3.1-16 Loop Seal Solids Organic Carbon 


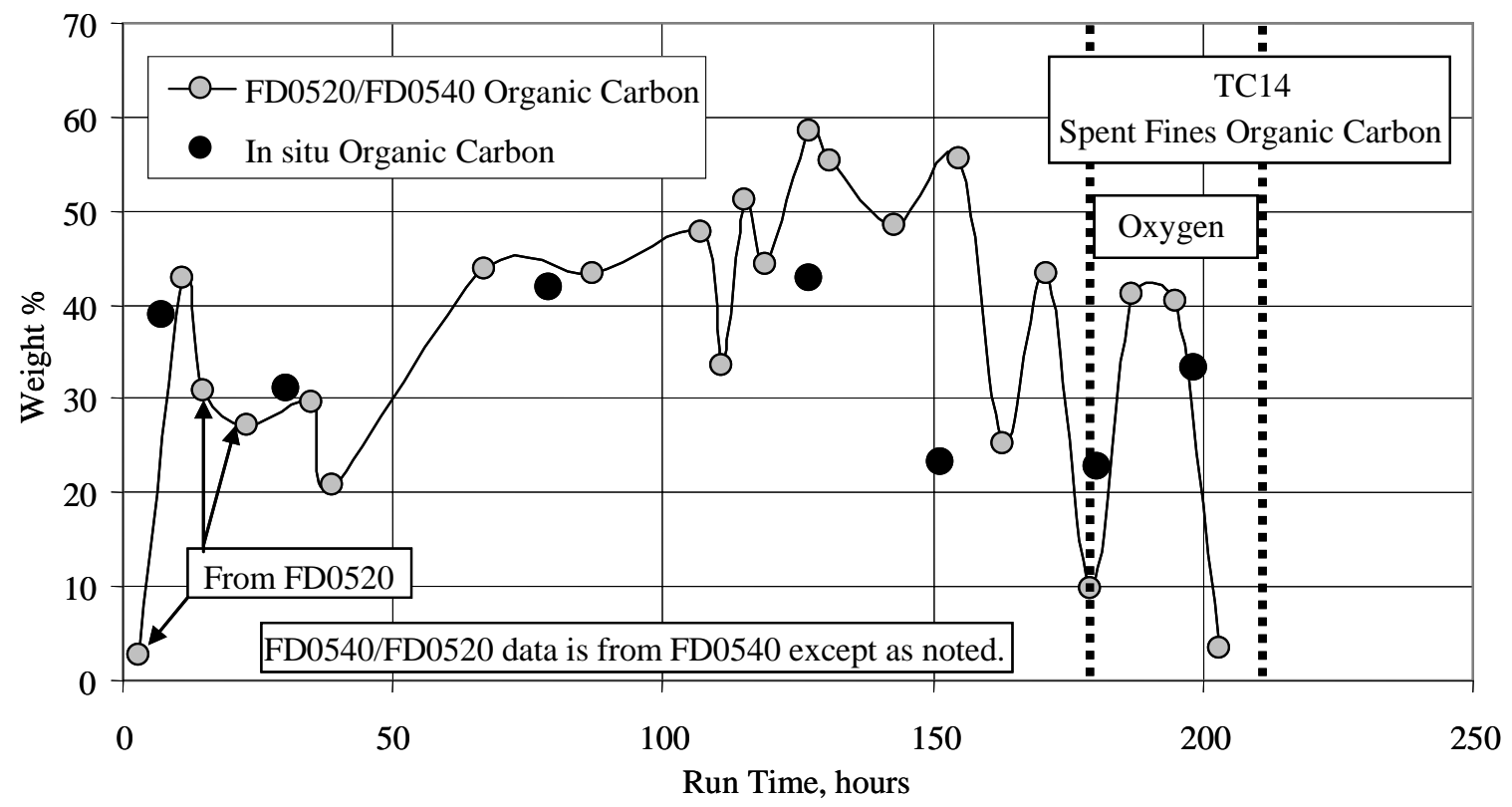

Figure 3.1-17 PCD Solids Organic Carbon

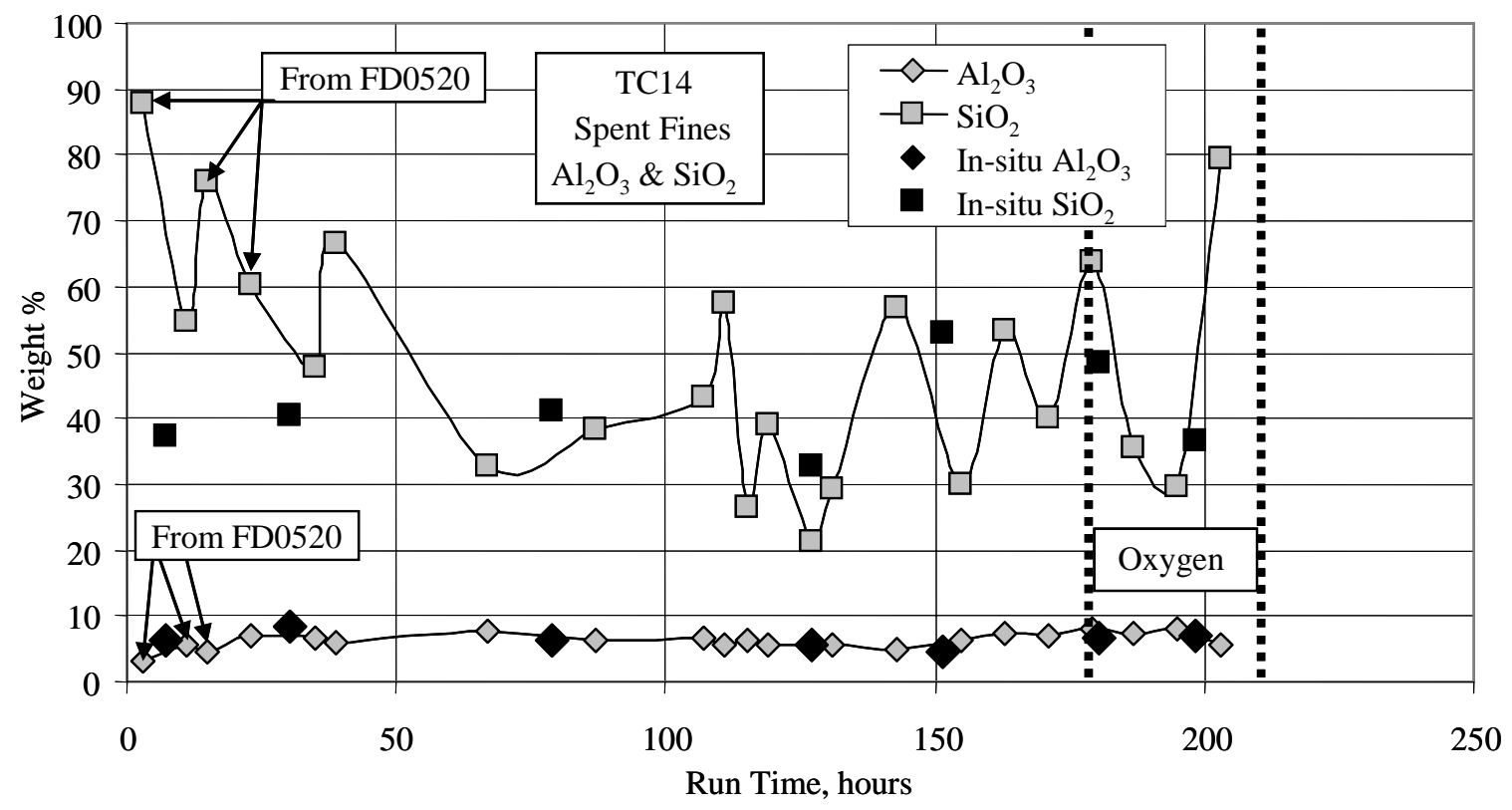

Figure 3.1-18 PCD Solids Silica \& Alumina 


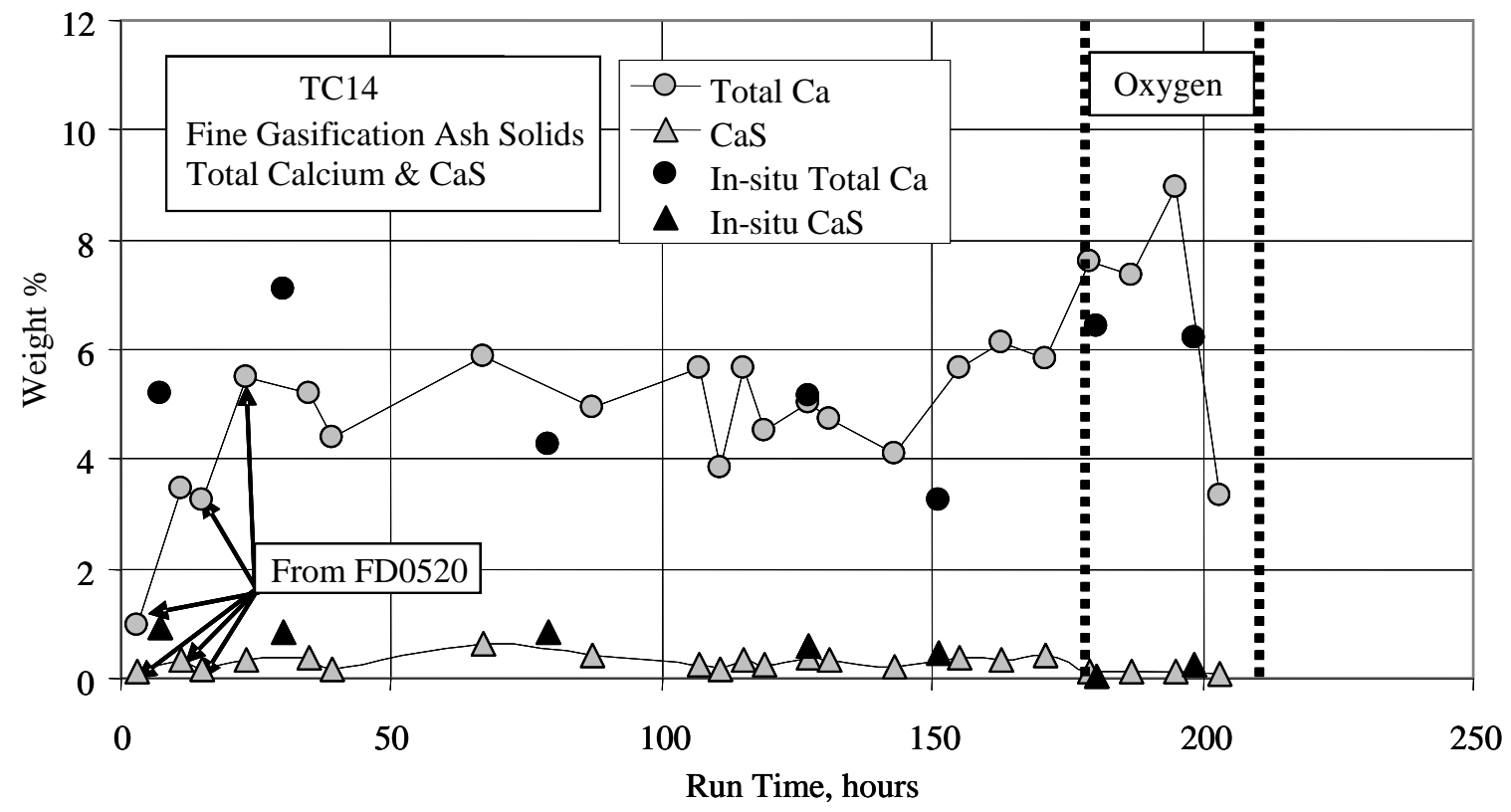

Figure 3.1-19 PCD Total Calcium \& Calcium Sulfide

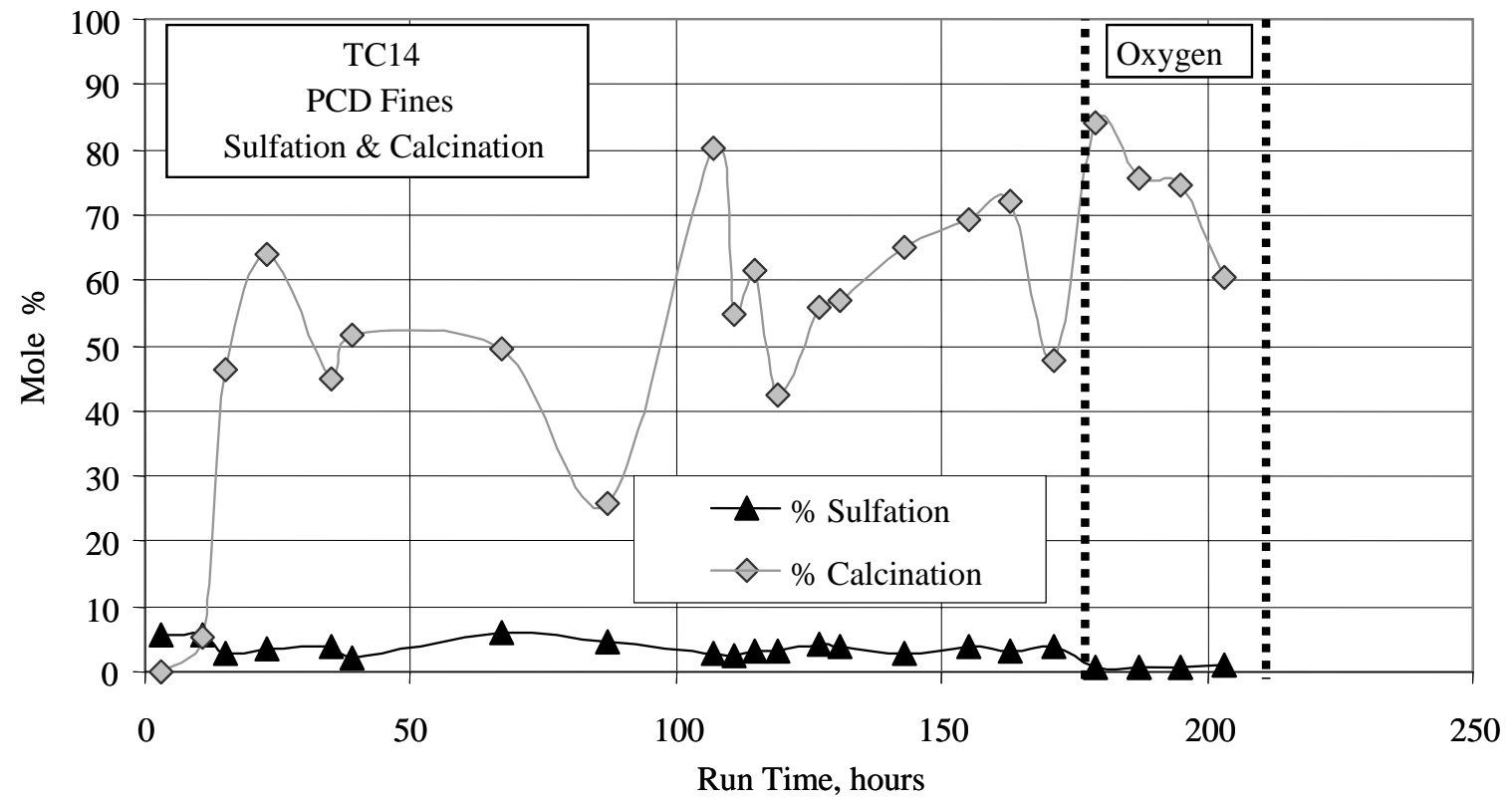

Figure 3.1-20 PCD Solids Calcination \& Sulfation 


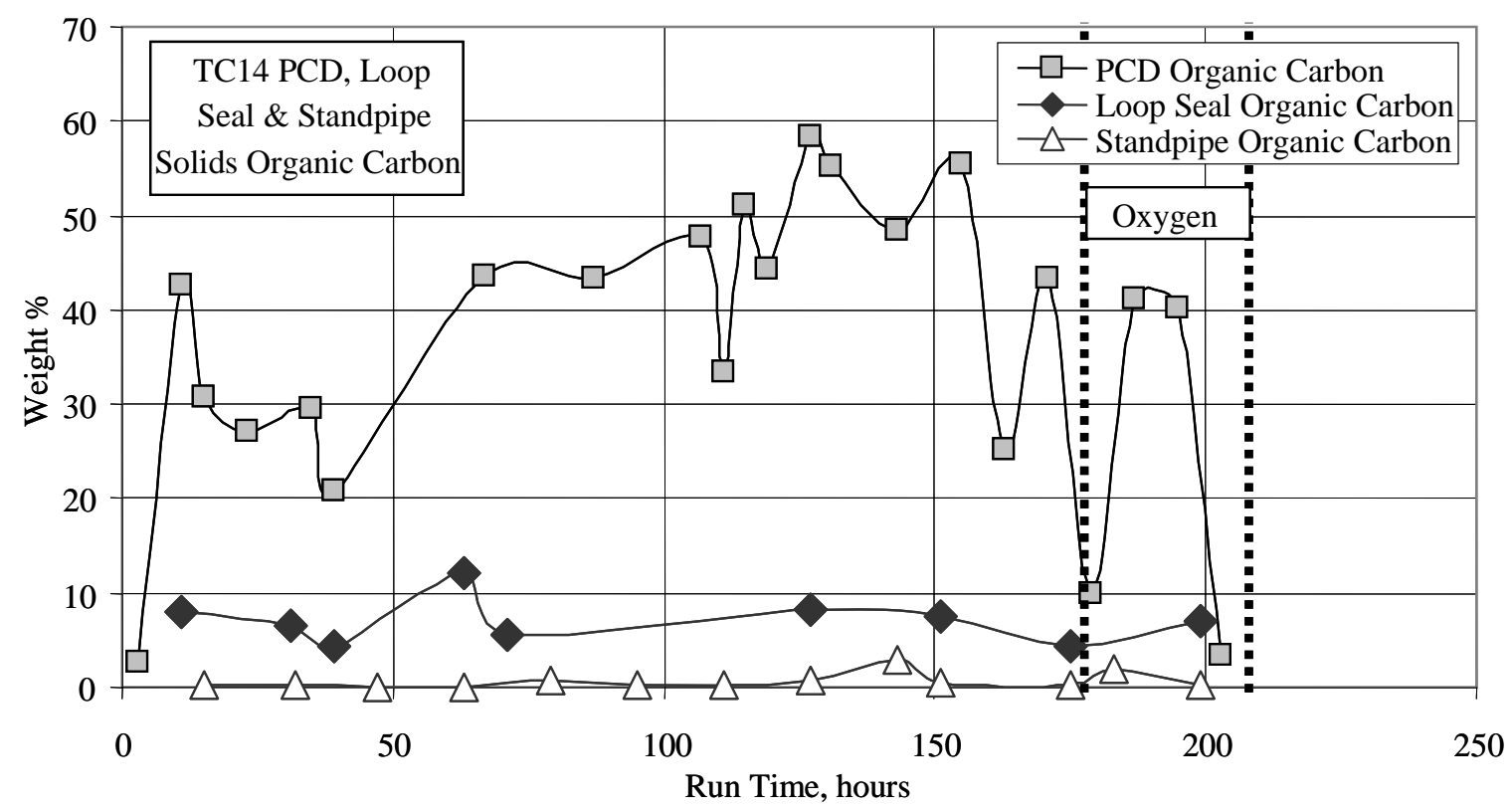

Figure 3.1-21 Standpipe, Loop Seal, and PCD Solids Organic Carbon Content

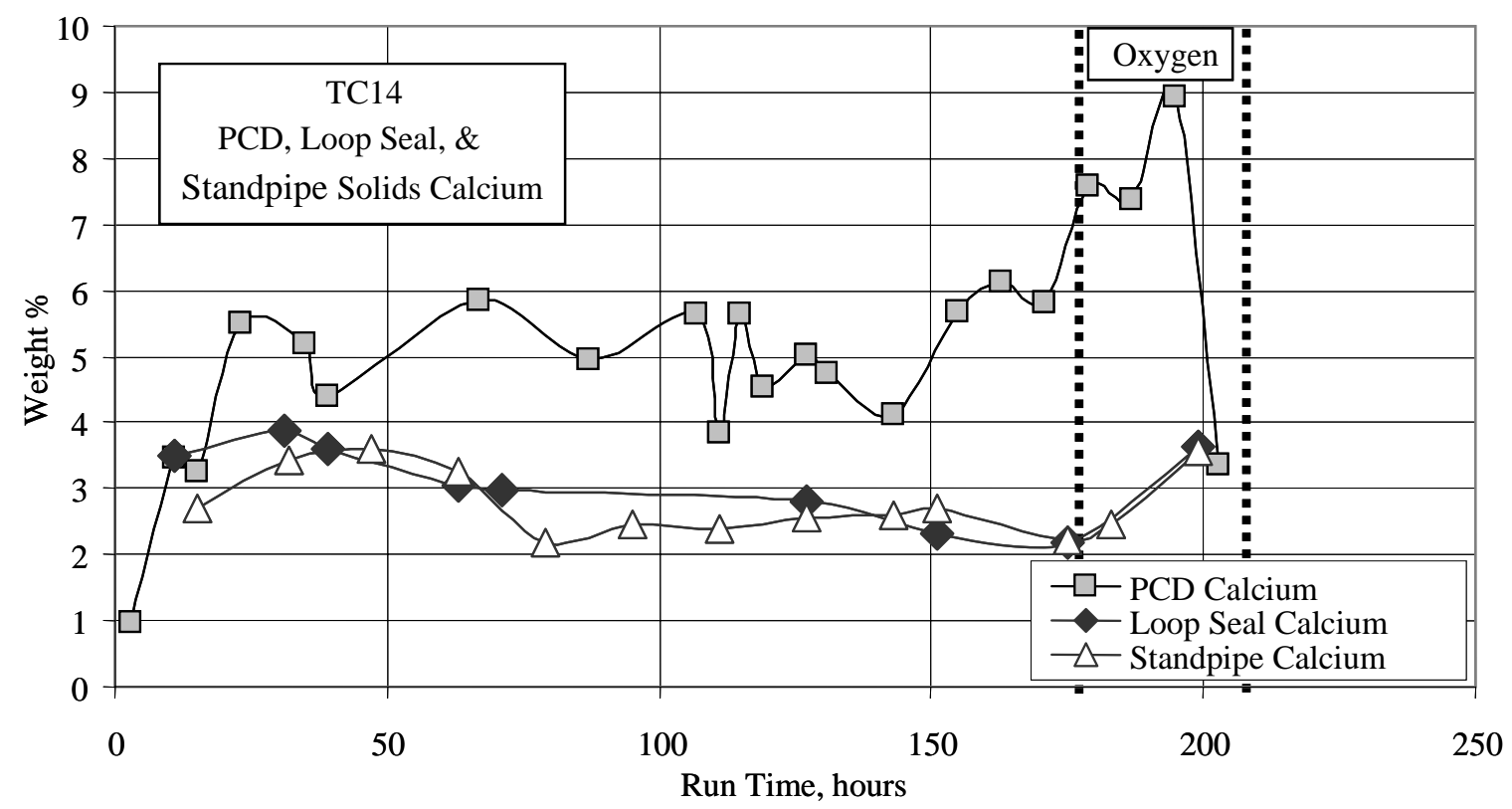

Figure 3.1-22 Gasifier \& PCD Solids Calcium 


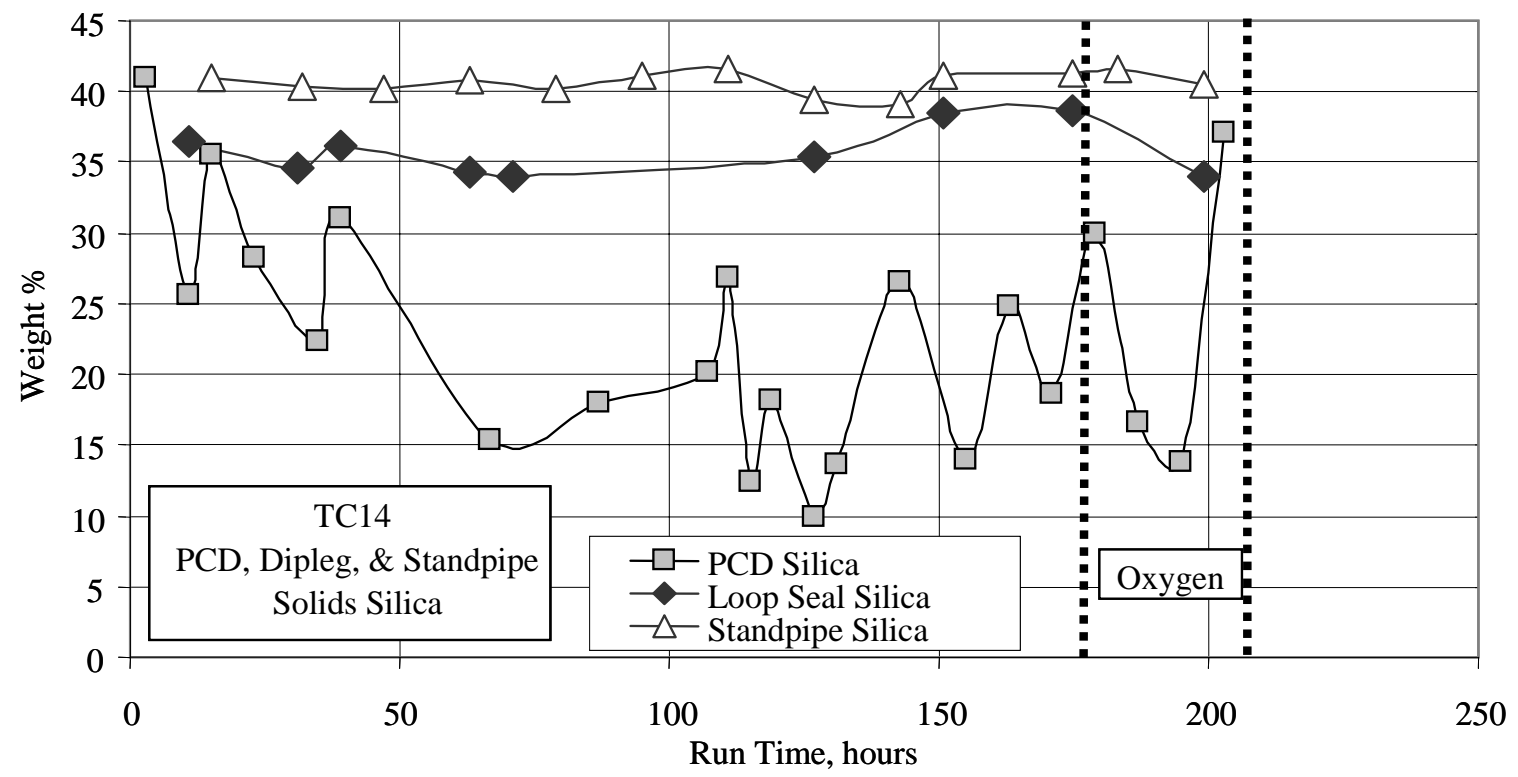

Figure 3.1-23 Gasifier \& PCD Solids Silica

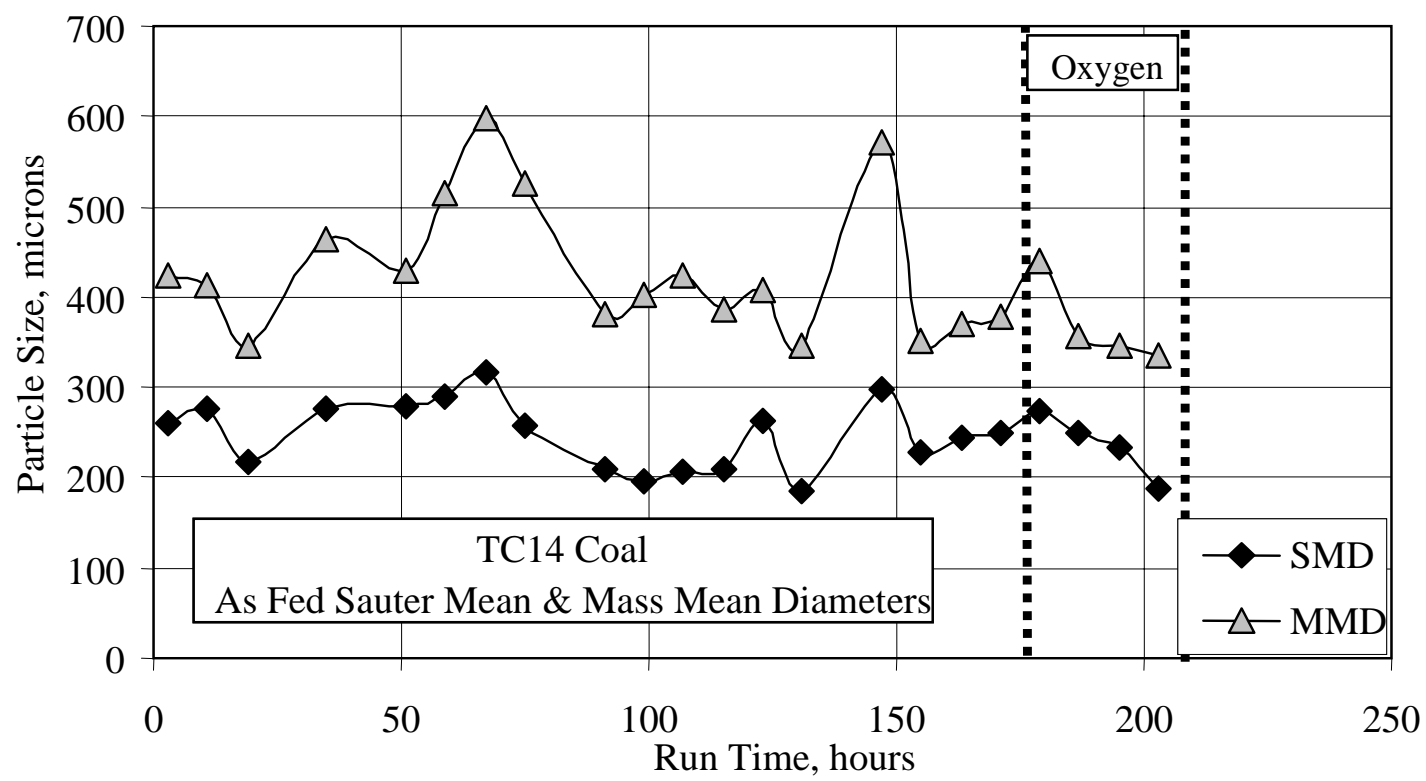

Figure 3.1-24 Coal Particle Size 


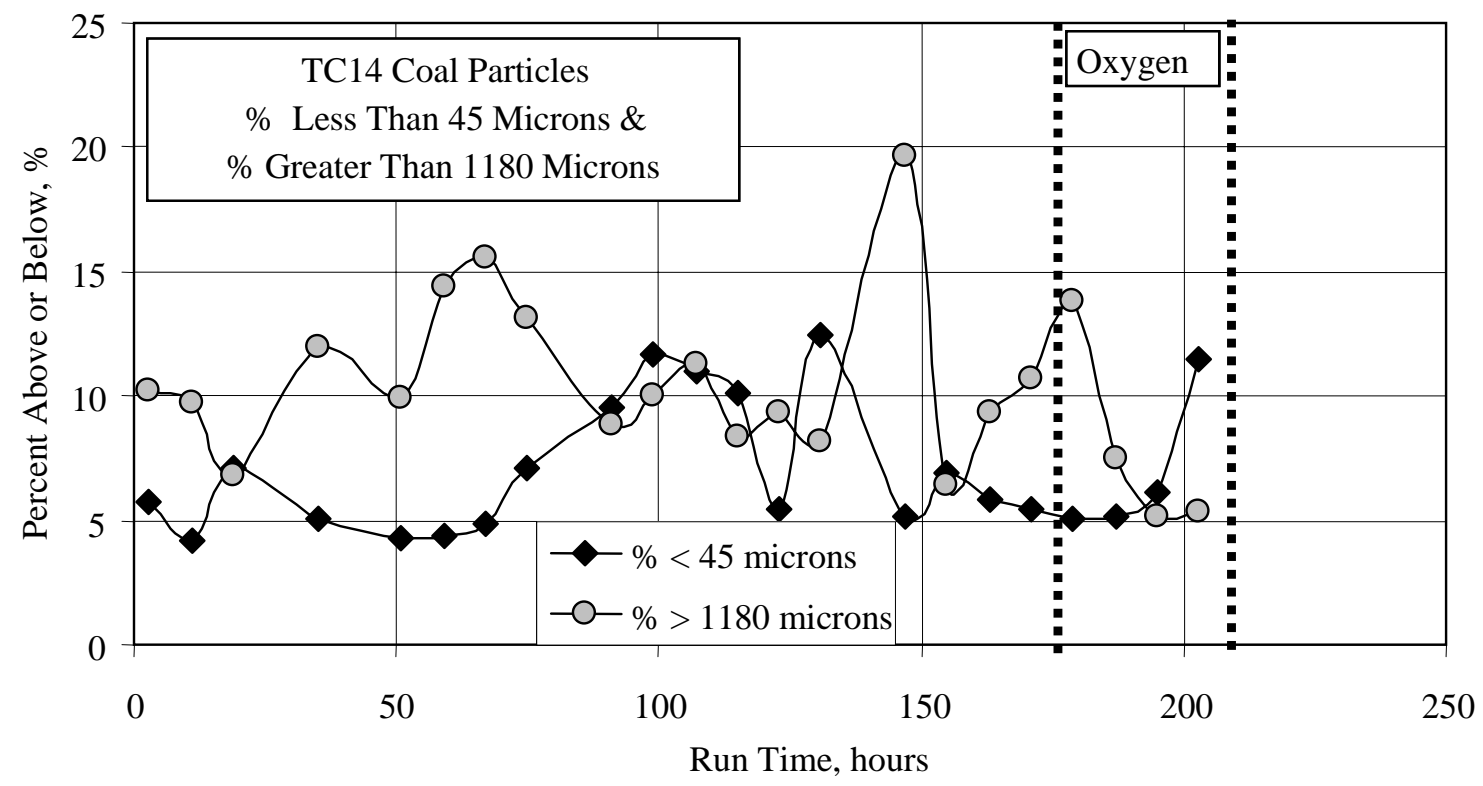

Figure 3.1-25 Percent Coal Fines \& Oversize

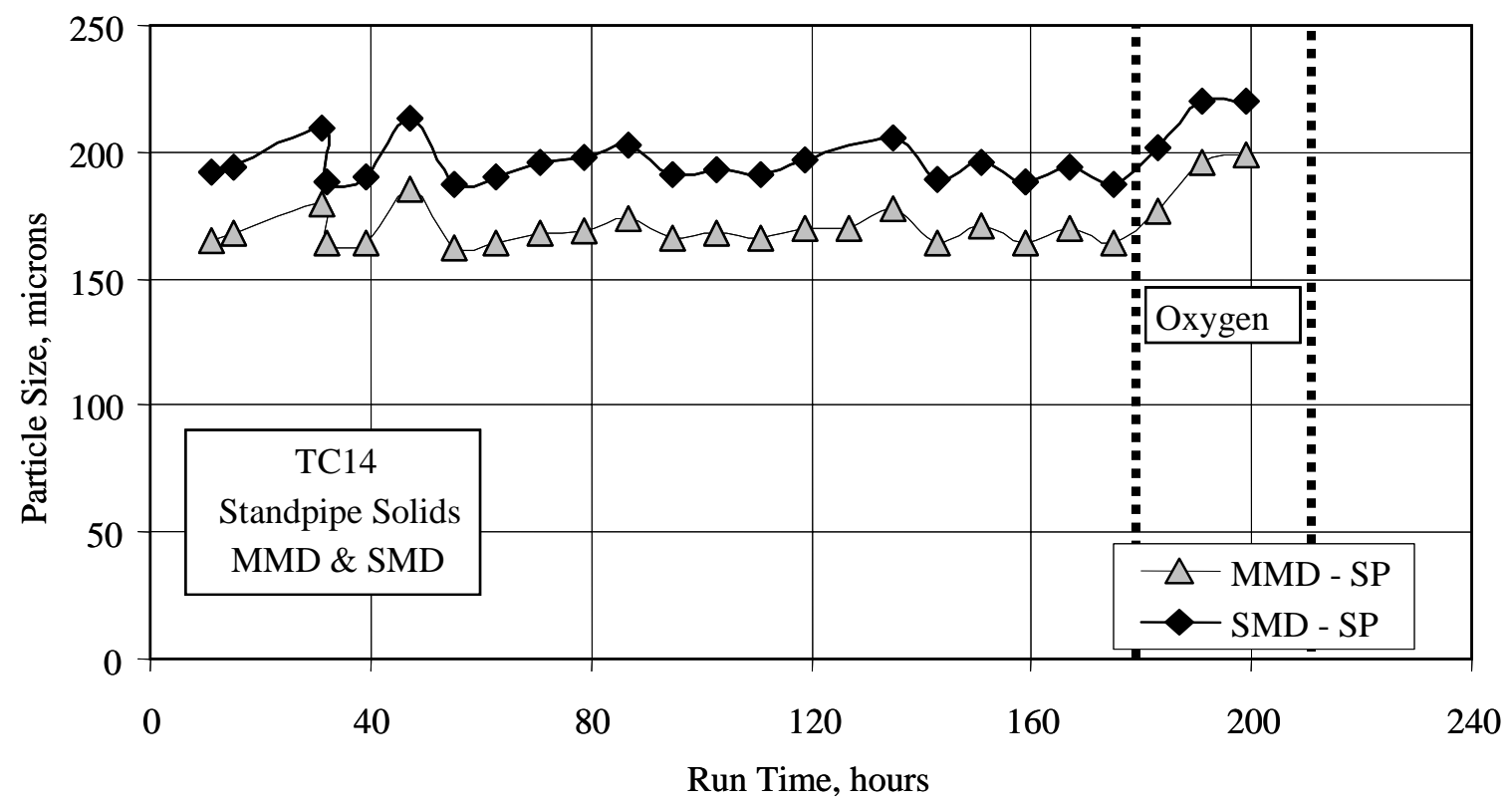

Figure 3.1-26 Standpipe Solids Particle Size 


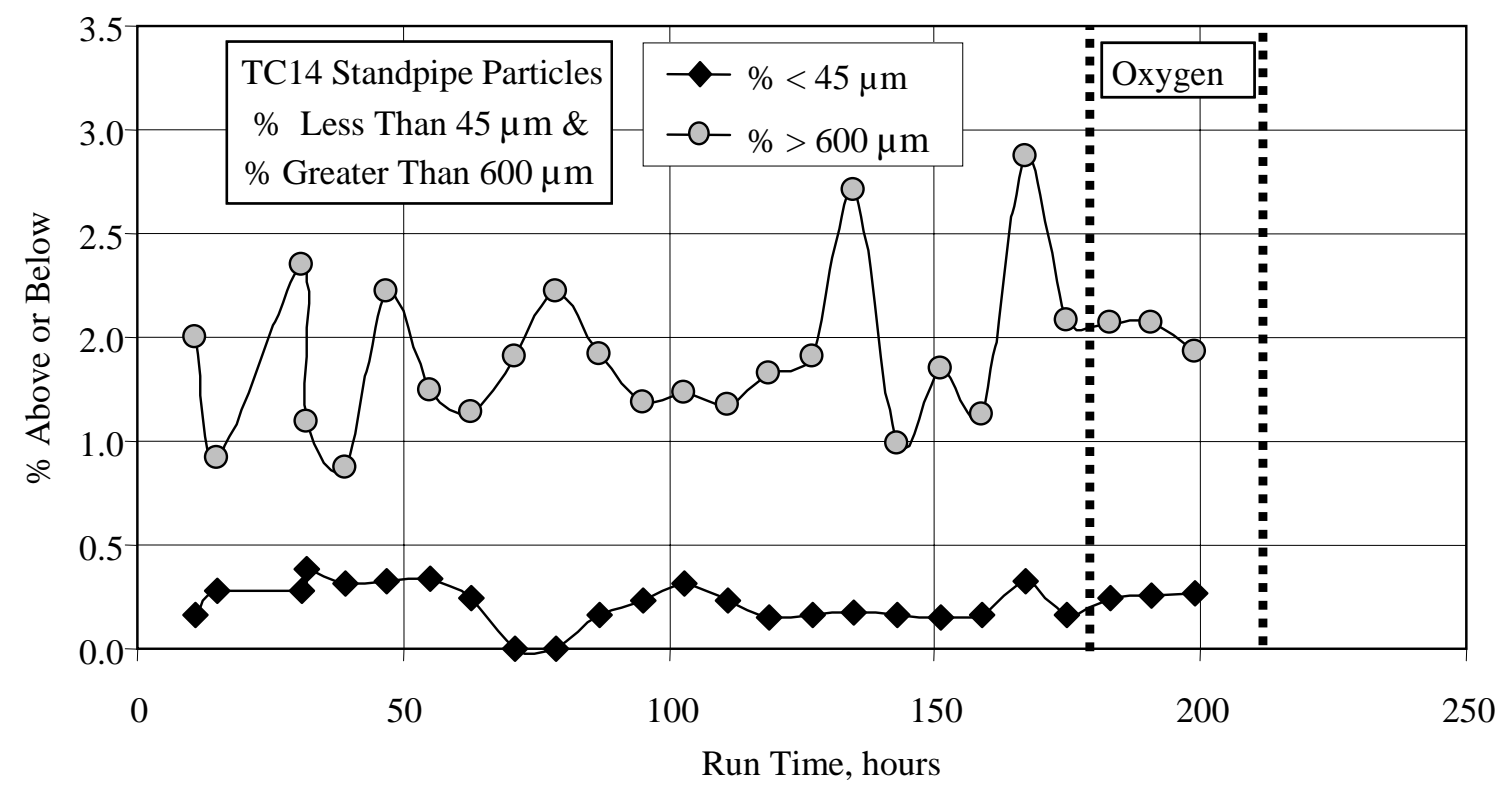

Figure 3.1-27 Standpipe Solids Fine and Coarse Particles

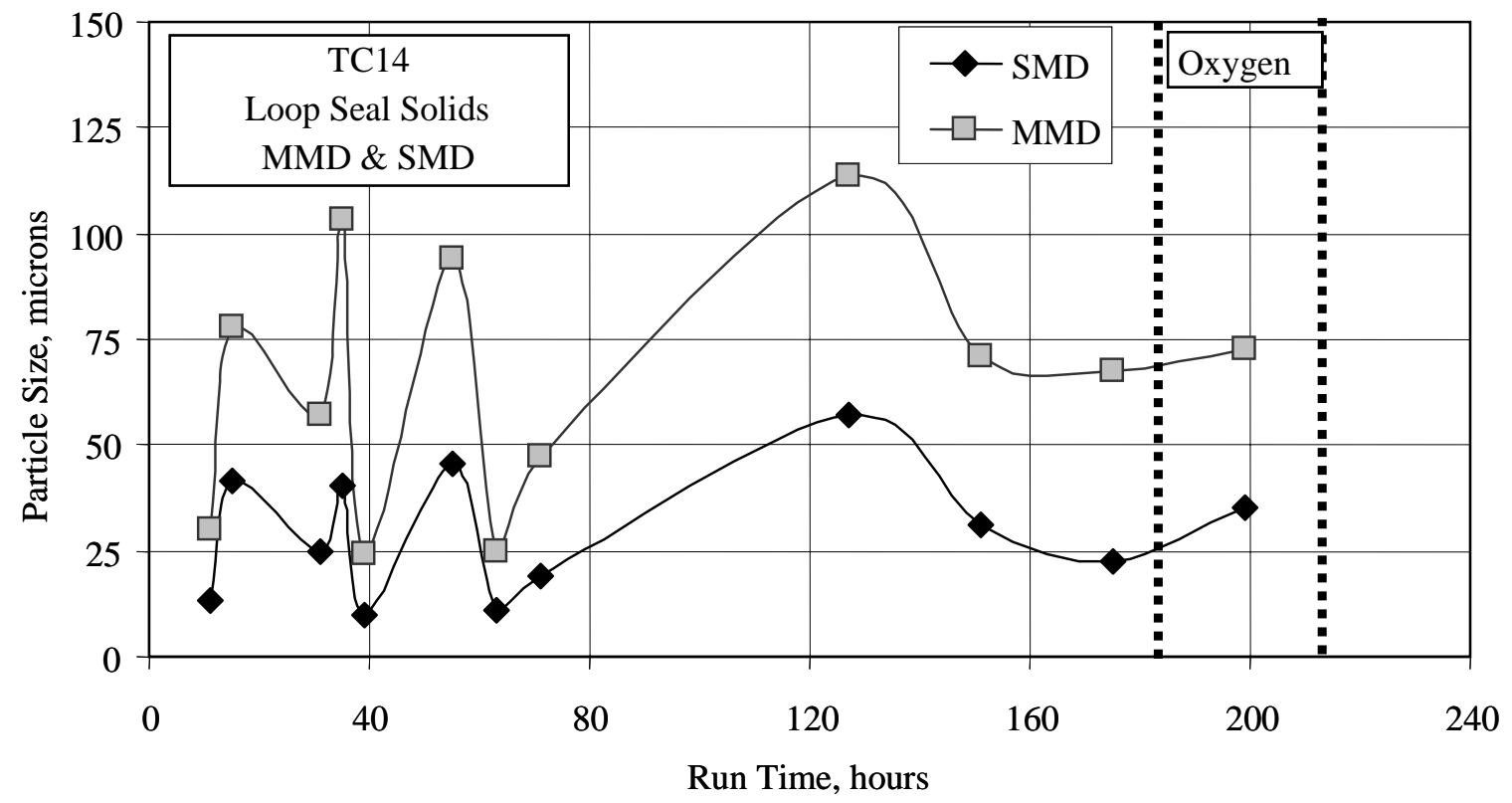

Figure 3.1-28 Loop Seal Solids Particle Sizes 


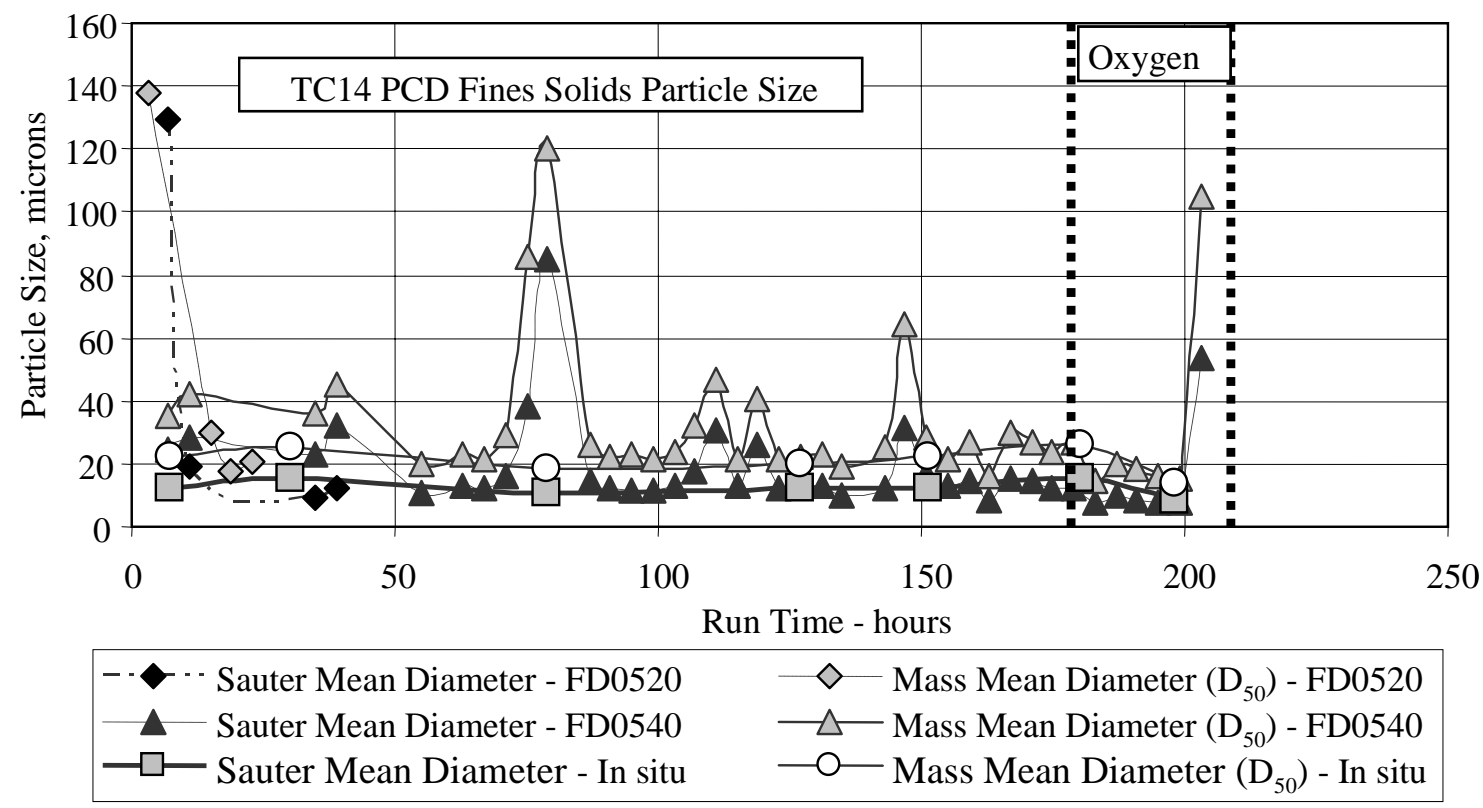

Figure 3.1-29 PCD Solids Particle Sizes

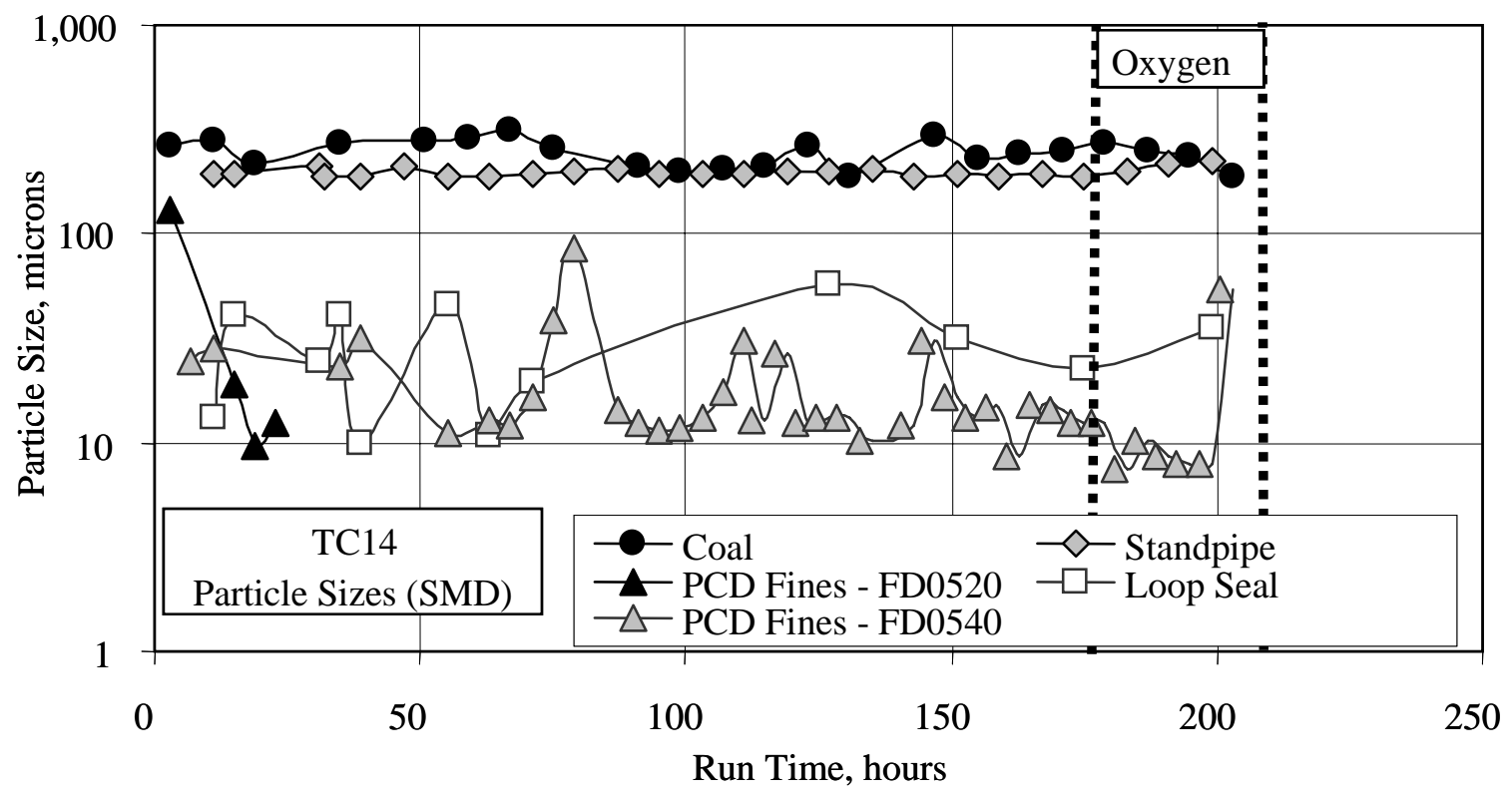

Figure 3.1-30 Particle Size Distribution 


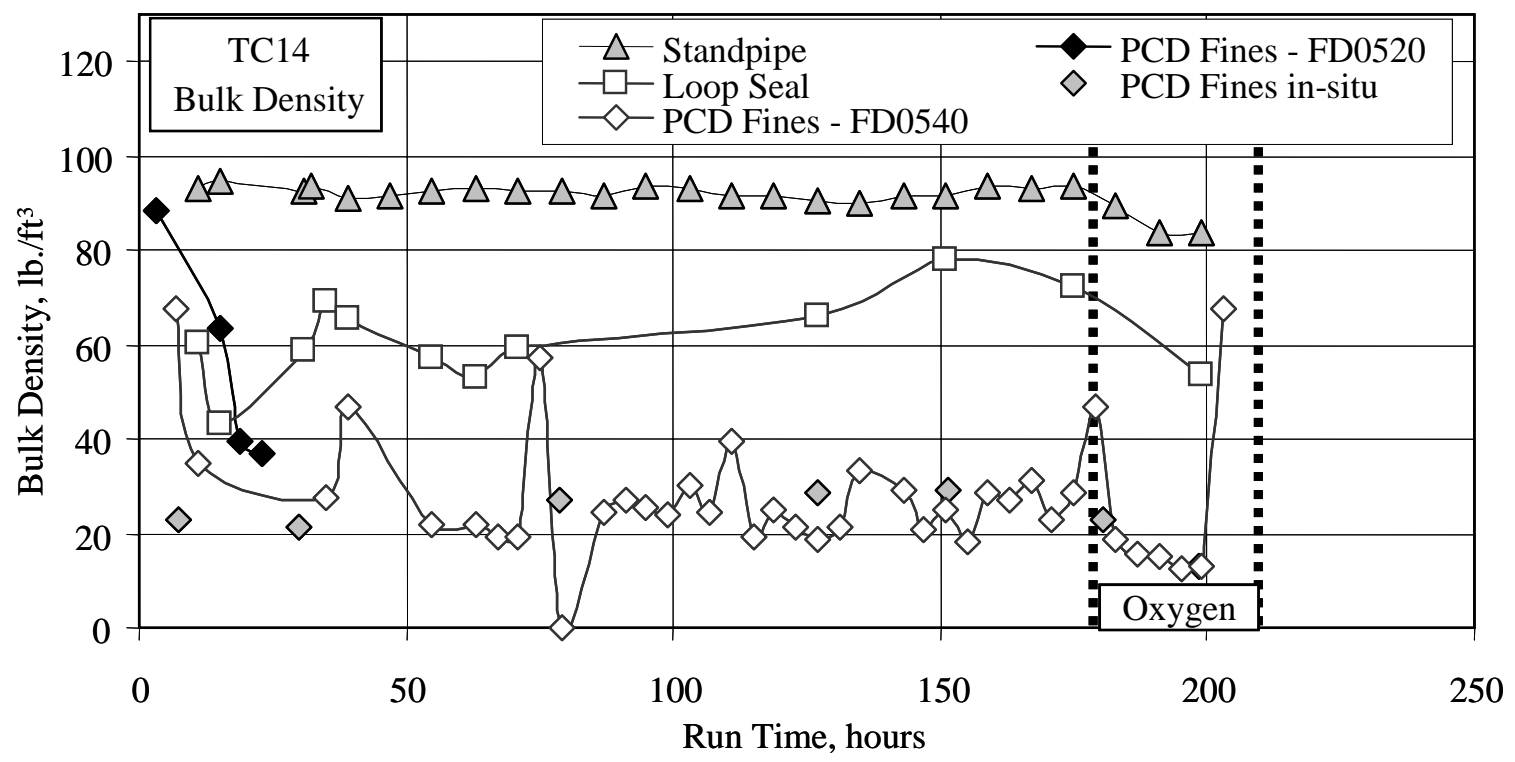

Figure 3.1-31 Gasifier \& PCD Solids Bulk Density

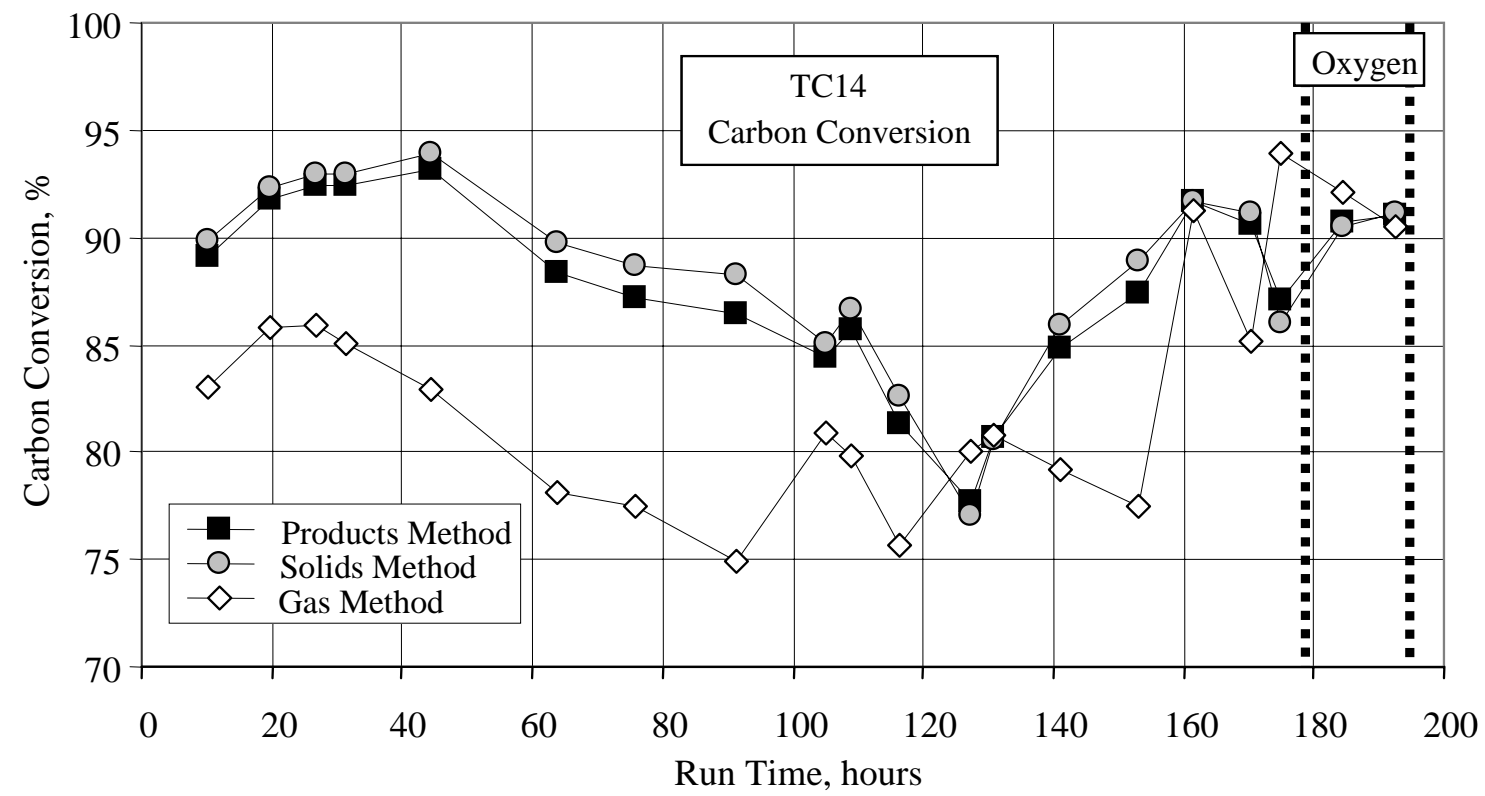

Figure 3.1-32 Carbon Conversion 


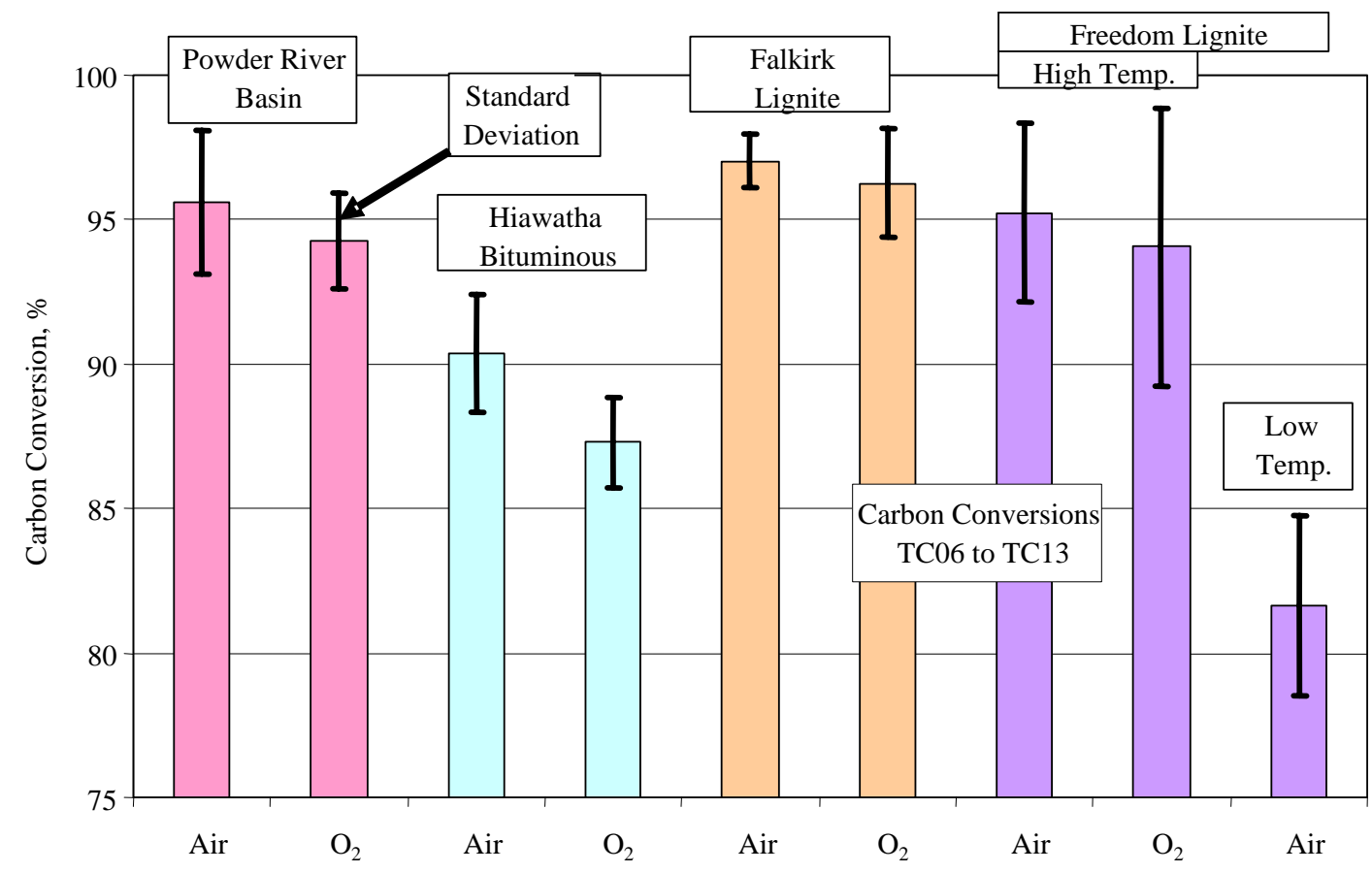

Figure 3.1-33 Carbon Conversion of Four Coals

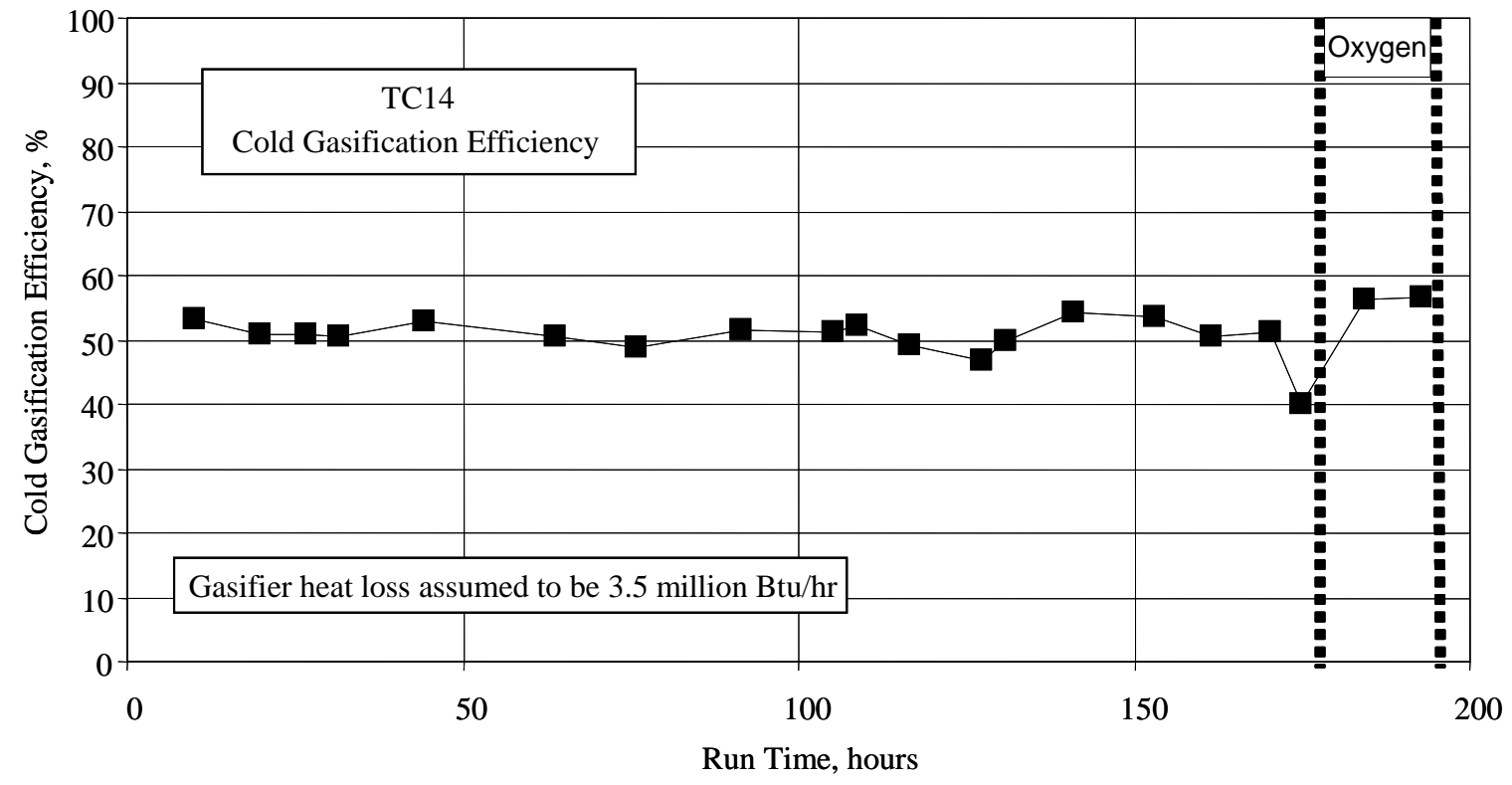

Figure 3.1-34 Cold Gasification Efficiency 


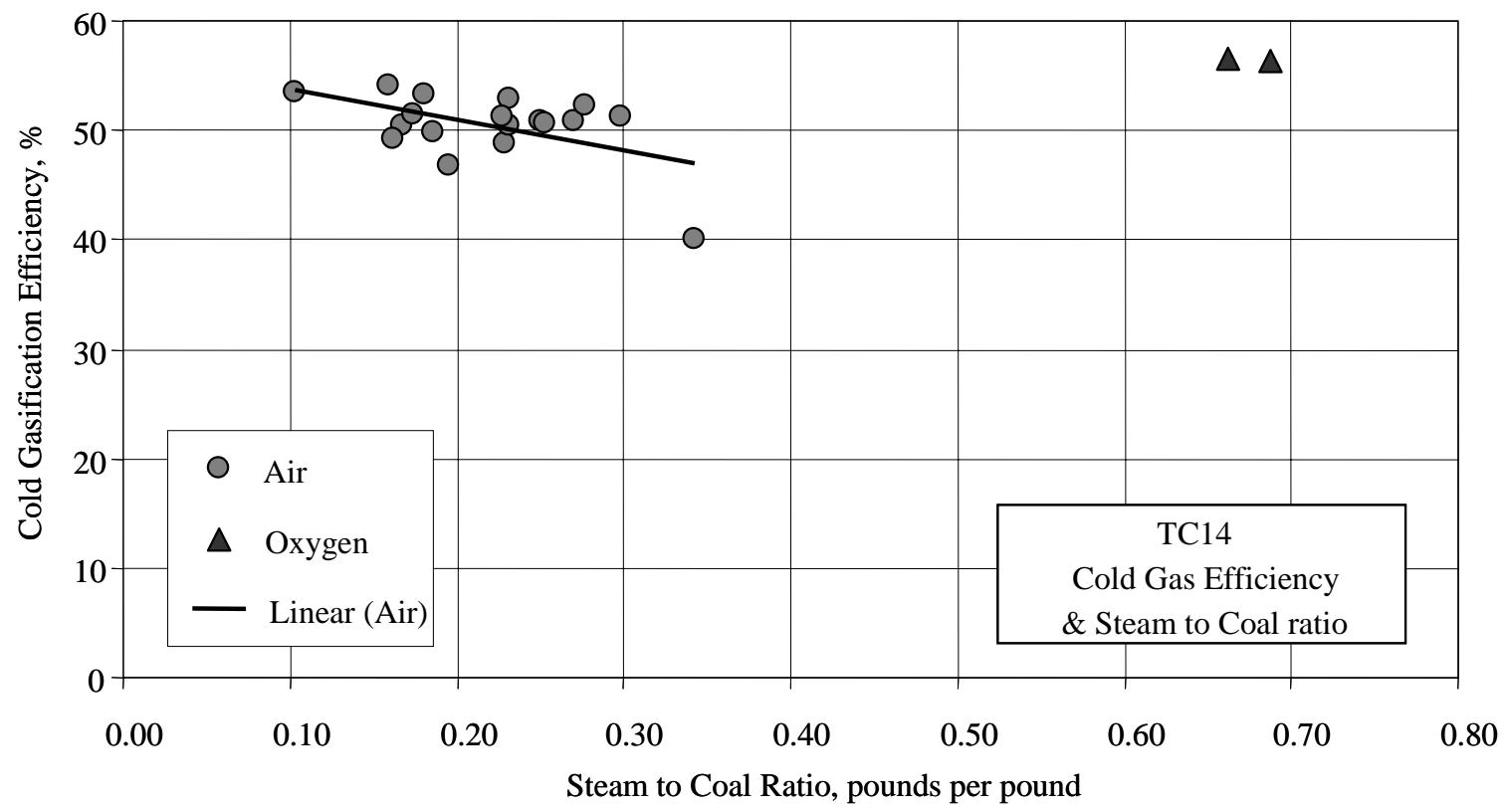

Figure 3.1-35 Cold Gasification Efficiency \& Steam to Coal Ratio

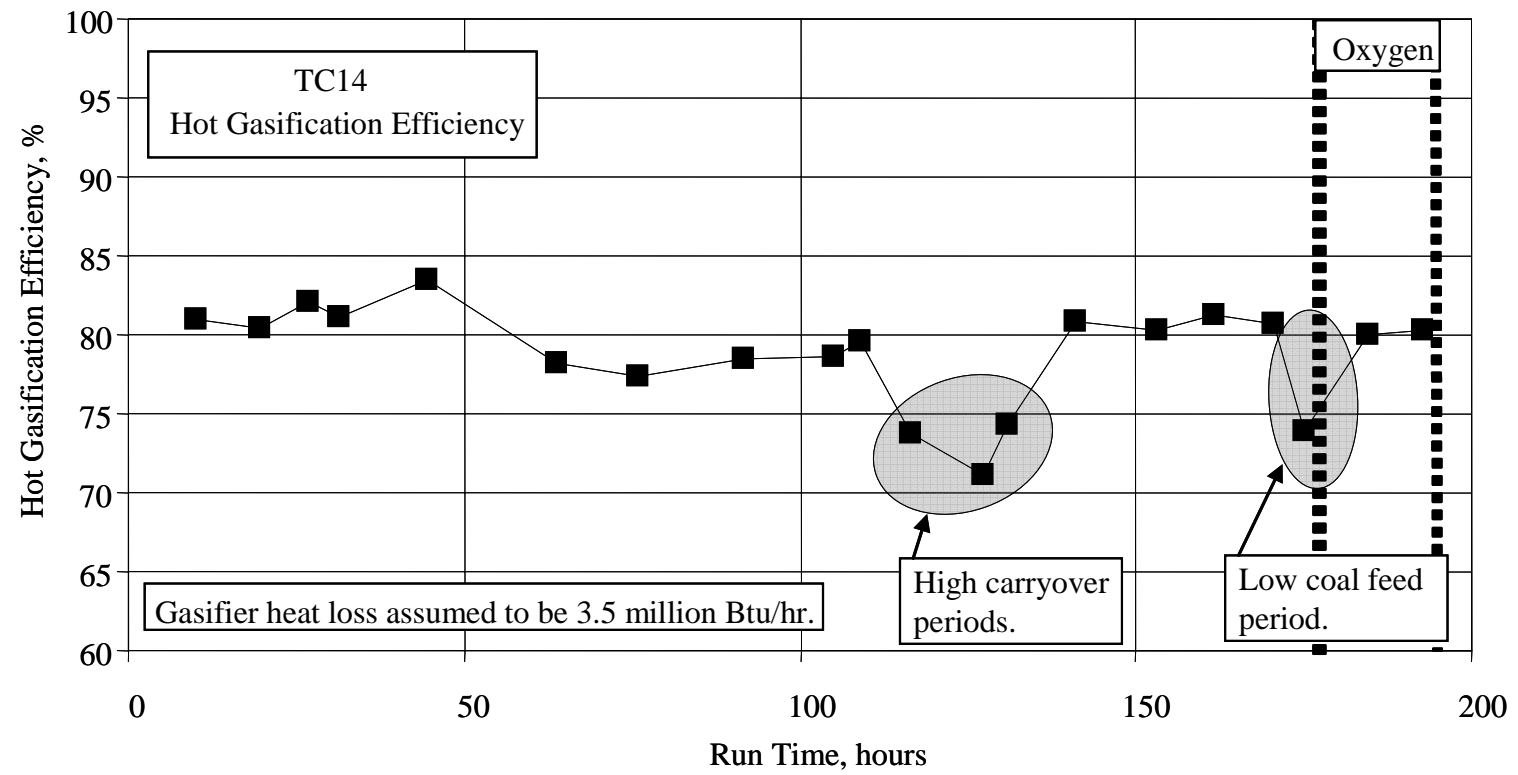

Figure 3.1-36 Hot Gasification Efficiency 


\subsection{PARTICULATE CONTROL DEVICE PERFORMANCE}

\subsubsection{Particle Mass Concentrations}

In situ particulate sampling was performed at the inlet and outlet of the PCD to quantify the particulate collection efficiency and to relate PCD performance to the characteristics of the dust entering the PCD.

Particle mass concentrations and mass rates measured at the PCD inlet are given in Table 3.2-1, and the mass rates are plotted as a function of coal feed rate in Figure 3.2-1. As shown, the mass rates measured in TC14 were significantly higher than those measured in TC12 when compared at the same coal feed rate. This increased rate of solids carryover to the PCD is suspected to be caused by a change in cyclone performance. Inspection of the cyclone internals revealed damaged refractory and deposits that probably degraded the performance of the cyclone, explaining the higher rates of solids carryover.

Particle mass concentrations measured at the PCD outlet are included in Table 3.2-1 and compared to other test programs in Figure 3.2-2. Generally, the outlet particle concentration was below the lower resolution limit of $0.1 \mathrm{ppmw}$, although slightly elevated concentrations ( 0.23 and $0.20 \mathrm{ppmw})$ were measured on the first two days of sampling. Inspection of the sampling filters confirmed the presence of fine gasification ash particles consistent with a small PCD leak during the first two sample runs. Outlet Run No. 7 yielded a particulate loading of 2.5 ppmw, because it was conducted during the injection of gasification ash downstream from the PCD to test the response of the PCME particulate monitor. A high outlet loading (3.3 ppmw) was also measured by Outlet Run No. 9, which was performed at the beginning of the gasification ash injection for the Ceramem failsafe test. The following section addresses the response of the PCME particulate monitor during both the failsafe testing and the injection downstream from the PCD.

\subsubsection{Real Time Particle Monitoring}

The DustAlert-90 particulate monitor manufactured by PCME, Inc. (referred to as the PCME) was operational throughout the test run. As seen in previous tests, there was considerable noise in the PCME signal along with spikes that coincided with PCD backpulses. Indicated in Figure 3.2-3, there was a clear elevation of the signal baseline during the injection of gasification ash into the PCD outlet pipe. As shown, the baseline signal increased immediately when the injection was started and remained elevated throughout the injection period. When the injection was terminated, the signal quickly returned to the original level.

The response of the PCME monitor during the CeraMem failsafe test is shown in Figure 3.2-4. Although there was no obvious elevation of the signal baseline during the failsafe test, there was an increase in the signal spikes immediately after the start of injection, which produced a definite increase in the signal 20-minute average. However, the magnitude of the response was much lower than it was during the injection into the outlet pipe, even though the measured particulate mass concentration was slightly higher during the failsafe test (3.3 ppmw versus $2.5 \mathrm{ppmw}$ ).

Figure 3.2-5 shows a plot of the average PCME output as a function of normalized particle concentration. The average PCME output is the average signal during the time period when the 
particle concentration measurement was being made. The particle concentrations shown on the graph are normalized to a syngas flow of $25,000 \mathrm{lb} / \mathrm{hr}$. It is necessary to normalize the particle concentration in this way, because the PCME monitor actually responds to the total mass rate of particles rather than the mass concentration. After this normalization, the particle concentration was essentially the same ( $\sim 2$ ppmw) during both the outlet pipe injection (labeled "PCME Test" on the graph) and during the failsafe injection (labeled "Failsafe Test" on the graph). The average PCME output was 1.8 percent during the PCME Test particle sampling run and only 0.5 percent during the Failsafe Test particle sampling run. Clearly, the instrument response was much lower than expected in the failsafe test.

To investigate the cause of the different PCME responses, the particle samples collected during the two tests were examined under the optical microscope. Figures 3.2-6 and 3.2-7 show photomicrographs of the samples collected during the PCME injection test and during the failsafe test, respectively. The sample from the PCME injection test (Figure 3.2-6) contains some very large ( $\sim 50$ micron) particles (or agglomerates) that are not present in the sample from the failsafe test (Figure 3.2-7). Since the sensitivity of the PCME monitor increases with increasing particle size, the presence of the large particles may explain the greater response of the instrument during the PCME injection test.

Figure 3.2-5 also compares the TC14 PCME response with the PCME responses obtained in previous tests (TC12, TC07, and TC06). The comparison suggests that there may have been a change in the sensitivity of the instrument. For a given normalized particle concentration, the PCME response in TC14 and TC12 appears to be somewhat lower than it was in TC06 and TC07. Although this comparison is based on limited data, it suggests a need to closely monitor the PCME response in future tests to determine whether the instrument is losing sensitivity.

\subsubsection{PCD Solids Analysis}

Gasification ash samples were collected in situ at the PCD inlet throughout TC14. The samples were thoroughly characterized to document particle size distributions, physical properties, chemical composition and flow resistance (drag). The PCD pressure drop and face velocity were monitored and used along with the measured particulate loading to determine the transient drag of the gasification ash. The transient drag values calculated by this method were compared to drag values measured in the laboratory.

\subsubsection{Particle Size Distributions}

A Microtrac X-100 particle size analyzer was used to measure the particle size distributions of the in situ particulate samples collected at the PCD inlet and the PCD hopper samples used for laboratory drag measurements. Figure 3.2-8 shows differential mass particle size distributions measured on the PCD inlet in situ samples. Figure 3.2-9 shows the same measurements expressed on the basis of differential mass percentage. For particle sizes smaller than about 30 to 40 microns, the distributions are all very similar on both the mass basis and the percentage basis. In the larger particle sizes, there is a slight difference between the air blown and oxygen blown runs. This difference is insignificant because the larger particles will not affect the laboratory drag measurements, since these particles are too large to be resuspended in the RAPTOR apparatus. Overall, the results seem to be consistent with previous measurements obtained with PRB coal that 
have shown no significant difference in particle size distributions under air blown and oxygen blown conditions.

Figure 3.2-10 shows the in situ and hopper particle size distributions. Two of the three selected hopper samples have size distributions that are very similar to those of the in situ samples.

However, the first selected hopper sample has a much coarser size distribution. This coarser size distribution could be a result of contamination with sand bed material. The coarser size distribution should not affect the laboratory drag measurements.

\subsubsection{PCD Dust Cake Observations}

A clean shutdown was performed on the PCD in which it was backpulsed for fourteen hours after coal feed was terminated. This procedure left no transient cake and a very thin residual cake on the filter elements. Table 3.2-2 summarizes the thickness and areal loading measurements made on the residual cake and compares the measurements to those made on residual cakes from previous runs. The average cake thickness was about 0.01 in., in agreement with previous measurements.

The thinnest cakes were found on the elements equipped with the Pall fuses that were installed on Hastelloy-X elements. The P09 element, which has larger pores than the P05 element, had the thinnest residual cake. This result was expected, since the P09 element would offer less flow resistance than the P05 element, and the lesser flow resistance would result in better backpulse cleaning of the P09 element. The thickest cakes were found on elements equipped with PSDF failsafes with the exception of one element that was equipped to two failsafes in series: a Pall fuse and a Westinghouse ceramic failsafe.

\subsubsection{Physical Properties and Chemical Compositions}

Tables 3.2-3 and 3.2-4 give the physical properties and chemical compositions of the in situ samples collected at the PCD inlet and PCD hopper samples used for laboratory drag measurements. As indicated in the tables, the first five in situ samples and all three of the hopper samples were collected during air blown gasification. The last two in situ samples were collected during oxygen blown operation. Below is a comparison of the characteristics of the in situ samples.

\begin{tabular}{|l|c|c|}
\hline Oxidant & Air & Oxygen \\
\hline Bulk density, g/cc & $0.34-0.47$ & $0.21-0.37$ \\
\hline Skeletal particle density, g/cc & $2.18-2.35$ & $2.23-2.42$ \\
\hline Uncompacted bulk porosity, \% & $78.8-85.5$ & $84.7-90.6$ \\
\hline Specific surface area, m ${ }^{2} / \mathrm{g}$ & $92-156$ & $122-204$ \\
\hline Mass median diameter, $\mu \mathrm{m}$ & $18.2-25.0$ & $14.1-25.9$ \\
\hline Non-carbonate carbon, wt \% & $23.3-42.9$ & $22.7-33.2$ \\
\hline CaCO ${ }_{3}+$ CaS + Ca0, wt \% & $6.3-12.0$ & $11.0-11.5$ \\
\hline Inerts (ash/sand), wt \% & $48.5-70.4$ & $55.3-66.3$ \\
\hline
\end{tabular}


For every one of the physical properties and chemical components shown above, there is overlap in the ranges obtained under air and oxygen blown conditions. This overlap confirms the conclusion from previous tests that the choice of oxidant (air or oxygen) has no significant effect on the physical properties or chemical composition of the gasification ash.

From Tables 3.2-3 and 3.2-4, it is clear that the in situ sample from Run No. 7 is out of line with the other TC14 in situ samples. The sample from Run No. 7 has an unusually low bulk density, high porosity, high surface area, and low mass median diameter. These factors would tend to give this sample an unusually high drag. Because of this effect, the transient drag from this particular run may be much higher than the drag measured in the lab using the hopper samples.

The following table compares the average characteristics of the TC14 in situ samples to previous in situ samples produced from PRB coal without limestone addition.

\begin{tabular}{|l|c|c|c|c|}
\cline { 2 - 5 } \multicolumn{1}{c|}{} & TC14 & TC12 & TC10 & TC08 \\
\hline Bulk density, g/cc & 0.38 & 0.27 & 0.27 & 0.25 \\
\hline Skeletal particle density, g/cc & 2.29 & 2.34 & 2.25 & 2.37 \\
\hline Uncompacted bulk porosity, \% & 83.5 & 88.5 & 88.0 & 89.3 \\
\hline Specific surface area, m²/g & 131 & 166 & 146 & 223 \\
\hline Mass median diameter, $\mu \mathrm{m}$ & 21.0 & 16.2 & 12.3 & 18.6 \\
\hline Non-carbonate carbon, wt \% & 33.4 & 34.1 & 39.4 & 37.5 \\
\hline CaC0 ${ }_{3}+$ CaS + Ca0, wt \% & 9.6 & 14.2 & 11.4 & 14.3 \\
\hline Inerts (ash/sand), wt \% & 57.0 & 50.7 & 49.2 & 48.3 \\
\hline
\end{tabular}

From the above comparison, it is clear that the characteristics of the TC14 gasification ash are not in line with the gasification ash characteristics from previous tests. The TC14 gasification ash has a much higher bulk density, lower bulk porosity, lower surface area, and larger mean particle size. The TC14 gasification ash also contains a relatively high concentration of inerts, which result in relatively low concentrations of carbon and calcium components. This may be a result of degraded cyclone performance. The TC14 gasification ash characteristics reported here are apparently not representative of the PRB gasification ash that would have been produced if the cyclone were performing properly.

Figure 3.2-11 shows the specific surface area of the TC14 in situ samples plotted as a function of the carbon content, along with samples from previous PRB runs. There are three of the TC14 in situ samples (Run Nos. 1, 3, and 4) that seem to be out of line with the previously established trend. Compared to previous PRB gasification ash, these three samples have unexpectedly low surface areas for their carbon contents. 
Due to a very thin residual dustcake, separate dustcake samples from individual filter elements could not be collected. It was necessary to limit sample collection to a single bulk sample from the top plenum and a single bulk sample from the bottom plenum. Tables 3.2-5 and 3.2-6 give the physical properties and chemical composition of the two bulk dustcake samples taken from the top and bottom plenums. The table below compares these samples to the TC14 in situ particulate samples.

\begin{tabular}{|l|c|c|c|c|}
\cline { 2 - 5 } \multicolumn{1}{c|}{} & $\begin{array}{c}\text { Top } \\
\text { Plenum }\end{array}$ & $\begin{array}{c}\text { Bottom } \\
\text { Plenum }\end{array}$ & $\begin{array}{c}\text { In situ } \\
\text { Range }\end{array}$ & $\begin{array}{c}\text { In situ } \\
\text { Average }\end{array}$ \\
\hline Bulk density, g/cc & 0.30 & 0.26 & $0.34-0.47$ & 0.38 \\
\hline Skeletal particle density, g/cc & 2.56 & 2.48 & $2.18-2.42$ & 2.29 \\
\hline Uncompacted bulk porosity, \% & 88.3 & 89.5 & $78.8-85.5$ & 83.5 \\
\hline Specific surface area, m²/g & 53 & 92 & $92-156$ & 131 \\
\hline Mass median diameter, $\mu \mathrm{m}$ & 6.0 & 7.4 & $18.2-25.9$ & 21.0 \\
\hline Non-carbonate carbon, wt \% & 19.9 & 33.1 & $22.7-42.9$ & 33.4 \\
\hline CaC0 3 + CaS + Ca0, wt \% & 13.1 & 14.2 & $6.3-12.0$ & 9.6 \\
\hline Inerts (ash/sand), wt \% & 67.1 & 52.8 & $48.5-70.4$ & 57.0 \\
\hline
\end{tabular}

As seen in previous tests, the residual cake appears to be enriched in fine particles ( 6 to 7 microns MMD of the cake versus 18 to 26 microns MMD for the in situ samples). Compared to the incoming gasification ash, the residual cake also has a lower bulk density, higher particle density, higher bulk porosity, and lower surface area. The dustcake samples have a slightly higher concentration of calcium components, but this difference is not considered to be significant. The surface area of the residual cake is typically lower than the surface area of the in situ samples. The lower surface area is due in part to closure of pores associated with additional reaction with $\mathrm{H}_{2} \mathrm{~S}$ and formation of $\mathrm{CaS}$. The residual cake contains 1.4 to 2.2 weight percent $\mathrm{CaS}$; while the in situ samples contain 0.02 to 0.9 weight percent $\mathrm{CaS}$.

The table below compares the average properties of the TC14 residual dustcake with those from other test campaigns that used PRB coal. 


\begin{tabular}{|lc|c|c|c|}
\cline { 2 - 5 } \multicolumn{1}{c|}{} & TC14 & TC12 & TC10 & TC06 \\
\hline Limestone added at end of run & No & Yes & No & Yes \\
\hline Bulk density, g/cc & 0.28 & 0.29 & 0.23 & 0.25 \\
\hline Skeletal particle density, g/cc & 2.52 & 2.27 & 2.06 & 2.28 \\
\hline Uncompacted bulk porosity, \% & 88.9 & 87.2 & 88.8 & 89.0 \\
\hline Specific surface area, m²/g & 73 & 82 & 92 & 257 \\
\hline Mass median diameter, $\mu \mathrm{m}$ & 6.7 & 9.6 & 4.5 & 9.3 \\
\hline Non-carbonate carbon, wt \% & 26.5 & 26.8 & 49.6 & 40.1 \\
\hline CaCO ${ }_{3}+$ CaS + Ca0, wt \% & 13.6 & 23.0 & 10.0 & 25.7 \\
\hline Inerts (ash/sand), wt \% & 60.0 & 50.2 & 40.4 & 34.2 \\
\hline
\end{tabular}

Compared to the other PRB cakes, the TC14 residual cake has a relatively high particle density (2.5 $\mathrm{g} / \mathrm{cc}$ versus 2.1 to $2.3 \mathrm{~g} / \mathrm{cc}$ ) and a relatively high concentration of inerts (60 weight percent versus 34 to 50 weight percent). These differences may be related, since the principal inert component sand - is denser than the gasification ash. According to the CRC Handbook of Chemistry and Physics, natural quartz sand has a density of 2.6 to $2.7 \mathrm{~g} / \mathrm{cc}$. As shown in the table above, the PRB gasification ash from previous runs had a density of 2.1 to $2.3 \mathrm{~g} / \mathrm{cc}$. The presence of an elevated amount of sand in the TC14 cake could explain the relatively high particle density and higher concentration of inerts.

Other than the unusual density and inerts content discussed above, the TC14 residual cake is fairly similar to the residual cakes from the previous PRB runs, except for the cake from TC06. As shown in the table above, the TC06 cake had an extremely high surface area. The TC06 in situ samples also had very high surface areas, and there was some char bridging at the end of TC06. If the dustcake sample were contaminated with bridged material that was similar to the in situ samples, the bridging contamination could account for the unusually high surface area of the TC06 cake.

\subsubsection{Drag Measurements}

Also included in Tables 3.2-3 and 3.2-4 is data for composite PCD hopper samples that were used for laboratory drag measurements. Previous measurements have shown that the carbon content of the gasification ash has an influence on drag. The composite hopper samples represented two different carbon contents, nominally 25 and 35 percent. As shown in the tables, the first composite had unusually high bulk and particle densities, low porosity, low surface area, large mean particle size, and high concentration of inerts. The second composite hopper sample appears to be fairly similar to the in situ samples, but the third composite has an unexpectedly high concentration of calcium components. The sum of calcium components $\left(\mathrm{CaCO}_{3}, \mathrm{CaS}\right.$, and $\left.\mathrm{CaO}\right)$ in the third composite sample is twice as high as the total calcium components in any of the other samples. The drag measurements from the third sample were disregarded due to measurement uncertainties. 
Analysis of the filter catches from the laboratory drag apparatus showed LOI values of 52 and 70 weight percent, approximately double the carbon content of the composite hopper samples that were used in the fluidized bed of the lab drag apparatus. This result suggests that the composite hopper samples contained a substantial amount of sand or other large particles that were not blown out of the fluidized bed feeder. Instead, it appears that the higher carbon gasification ash particles were preferentially blown out. A similar effect would probably take place in the PCD, where the larger particles would drop out, and only the finer material would reach the filter elements.

The drag results as a function of particle size for the two composite hopper samples are shown in Figure 3.2-12. The solid lines on the figure are the linear regression fits of the drag versus particle size data. The dashed lines are predicted by a multiple regression model that takes into account both the particle size and the LOI of the RAPTOR filter catches. Analysis of the TC14 data showed that using the LOI/carbon content of the filter catch results in a better correlation. The multipleregression model seems to fit the data just as well as the two separate linear regressions, suggesting that the multiple-regression approach does indeed accurately account for the effect of carbon of drag.

\subsubsection{PCD Pressure Drop}

During each in situ sampling run, the PCD transient drag was calculated using the measured pressure drop, gas flow, and particle concentration (see Table 3.2-7). The calculated transient drag at PCD conditions is listed under the column heading "PCD." The corresponding normalized value of transient drag at room temperature is listed under the heading "PCD@RT." This value can be compared directly with the lab measured drag values.

It was noted that the lab drag measurements were affected by the carbon content/LOI of the dust. The PCD transient drag values (corrected to room temperature) are plotted as a function of noncarbonate carbon content in Figure 3.2-13, along with data from previous PRB runs. There is considerable scatter in the data due to variations in equipment configuration, process conditions, coal composition, and limestone addition. Nevertheless, the data show a definite trend toward increasing drag with increasing carbon content. The three TC14 samples that were previously identified as outliers on the graph of surface area versus carbon content are seen to also be outliers in Figure 3.2-13. The inordinately low surface areas of these samples may be the cause of their relatively low transient drags.

The values of carbon content (NCC) and particle size (MMD) used to calculate the lab drag for each PCD test condition are shown in Table 3.2-7 along with the calculated drag from the multiple regressions in the first column labeled "RAPTOR". This value of RAPTOR drag is based on the multiple regression equation derived from the drag data, MMD data, and LOI data for the RAPTOR filter catches. The second column labeled "RAPTOR" is based on the simple linear regression of drag versus MMD that has been used in the past. As shown in the table, the multiple regression using the actual RAPTOR filter catch LOI yields drag values that most closely match the normalized PCD transient drag at room temperature (PCD@RT).

Figure 3.2-14 compares the values of PCD@RT to the corresponding individual values of RAPTOR drag calculated from the multiple regression model described above. Although there is again considerable scatter in the data, the data points are generally scattered around the perfect agreement 
line. The three TC14 runs that were previously identified as outliers in terms of surface area versus carbon and PCD transient drag versus carbon are not outliers on the graph of RAPTOR drag versus PCD transient drag. Overall, the cumulative drag data based on RAPTOR and on actual PCD performance continue to show fairly good agreement. In the case of the TC14 data, any better agreement is achieved as a result of using the multiple regression model based on the MMD and LOI of the RAPTOR filter catch. Both the lab measurements and PCD $\Delta \mathrm{P}$ show there is a strong variation of drag with carbon content of the gasification ash. 
Table 3.2-1

PCD Inlet and Outlet Particulate Measurements for TC14

\begin{tabular}{|c|c|c|c|c|c|c|c|c|c|c|}
\hline \multirow{3}{*}{$\begin{array}{l}\text { Test } \\
\text { Date }\end{array}$} & \multicolumn{5}{|c|}{ PCD Inlet } & \multicolumn{5}{|c|}{ PCD Outlet } \\
\hline & \multirow{2}{*}{$\begin{array}{l}\text { Run } \\
\text { No. }\end{array}$} & \multirow{2}{*}{$\begin{array}{l}\text { Start } \\
\text { Time }\end{array}$} & \multirow{2}{*}{$\begin{array}{l}\text { End } \\
\text { Time }\end{array}$} & \multicolumn{2}{|c|}{ Particle Loading, } & \multirow{2}{*}{$\begin{array}{l}\text { Run } \\
\text { No. }\end{array}$} & \multirow{2}{*}{$\begin{array}{l}\text { Start } \\
\text { Time }\end{array}$} & \multirow{2}{*}{$\begin{array}{l}\text { End } \\
\text { Time }\end{array}$} & \multirow{2}{*}{$\begin{array}{c}\mathrm{H}_{2} \mathrm{O} \\
\text { Vapor, } \\
\text { vol \% } \\
\end{array}$} & \multirow{2}{*}{$\begin{array}{c}\text { Particle } \\
\text { Loading, } \\
\text { ppmw }\end{array}$} \\
\hline & & & & ppmw & $\mathrm{lb} / \mathrm{hr}$ & & & & & \\
\hline \multicolumn{11}{|c|}{ Air Blown - PRB } \\
\hline $2 / 20 / 04$ & 1 & 10:10 & $10: 25$ & 25800 & 499 & 1 & $10: 00$ & 13:00 & 8.3 & 0.23 \\
\hline $2 / 21 / 04$ & 2 & 09:00 & $09: 15$ & 22600 & 411 & 2 & 08:00 & $12: 00$ & 8.7 & 0.20 \\
\hline $2 / 23 / 04$ & 3 & 09:45 & $10: 00$ & 27900 & 504 & 3 & 09:30 & $13: 30$ & 9.2 & $<0.10$ \\
\hline $2 / 24 / 04$ & .- & .. & .. & .. & .. & 4 & 09:00 & 13:15 & 12.2 & $<0.10$ \\
\hline $2 / 25 / 04$ & 4 & $10: 00$ & $10: 15$ & 44000 & 873 & 5 & $09: 45$ & $12: 20$ & $8.0^{(1)}$ & $<0.10$ \\
\hline 2/26/04 & 5 & $10: 15$ & $10: 30$ & 30400 & 507 & 6 & $10: 00$ & $13: 30$ & 8.5 & $<0.10$ \\
\hline $2 / 26 / 04$ & -. & .- & .- & .- & -. & 7 & $16: 15$ & $17: 15$ & -. & $2.54^{(2)}$ \\
\hline \multicolumn{11}{|c|}{ Oxygen Blown - PRB } \\
\hline $2 / 27 / 04$ & 6 & $15: 00$ & $15: 30$ & 24800 & 363 & 8 & $14: 52$ & $15: 52$ & 26.0 & $<0.10^{(3)}$ \\
\hline $2 / 27 / 04$ & -- & -. & -. & -. & -. & 9 & $17: 35$ & 18:35 & 21.9 & $3.34^{(4)}$ \\
\hline $2 / 28 / 04$ & 7 & $09: 15$ & $09: 30$ & 28800 & 366 & 10 & 08:00 & $12: 00$ & 16.0 & $<0.10^{(5)}$ \\
\hline Notes: & \multicolumn{10}{|c|}{$\begin{array}{l}\text { 1. Condenser stopped up with tar. Some water may have been lost. } \\
\text { 2. Dust injection for testing PCME monitor. } \\
\text { 3. Dust injection to Pall failsafe - Sampling time 00:15 through 01:15 after start of dust injection. } \\
\text { 4. Dust injection to Ceramem failsafe - Sampling time 00:15 through 01:15 after start of dust injection. } \\
\text { 5. Dust injection to Ceramem failsafe - Sampling time 14:40 through 18:40 after start of dust injection. }\end{array}$} \\
\hline
\end{tabular}


Table 3.2-2

Residual Cake Measurements from TC14 and Previous Runs

\begin{tabular}{|c|c|c|c|c|c|}
\hline $\begin{array}{l}\text { Element } \\
\text { No. }\end{array}$ & $\begin{array}{c}\text { Element/ } \\
\text { Failsafe Type }\end{array}$ & $\begin{array}{c}\text { Type of } \\
\text { Shutdown }\end{array}$ & $\begin{array}{c}\text { Thickness } \\
\text { in. }\end{array}$ & $\begin{array}{c}\text { Areal } \\
\text { Loading } \\
\mathrm{lb} / \mathrm{ft}^{2}\end{array}$ & $\begin{array}{c}\text { Calculated } \\
\text { Porosity } \\
\%\end{array}$ \\
\hline \multicolumn{6}{|c|}{ TC14 Measurements } \\
\hline \multicolumn{6}{|c|}{ Top Plenum } \\
\hline T-5 & FEAL/PSDF & Clean & 0.013 & 0.016 & 88.6 \\
\hline T-14 & FEAL/PSDF & Clean & 0.019 & 0.016 & 92.7 \\
\hline \multicolumn{6}{|c|}{ Bottom Plenum } \\
\hline B-4 & $\begin{array}{c}\text { Hastelloy-X P09/ } \\
\text { Pall Fuse }\end{array}$ & Clean & 0.009 & 0.006 & 94.6 \\
\hline B-5 & $\begin{array}{c}\text { Hastelloy-X P05/ } \\
\text { Pall Fuse }\end{array}$ & Clean & 0.012 & 0.007 & 94.9 \\
\hline B-8 & $\begin{array}{l}\text { FEAL/Pall Fuse + } \\
\text { SWPC Ceramic }\end{array}$ & Clean & 0.016 & 0.004 & 97.5 \\
\hline B-13 & FEAL/PSDF & Clean & 0.016 & 0.005 & 97.2 \\
\hline Average & & Clean & 0.014 & 0.009 & 94.3 \\
\hline \multicolumn{6}{|c|}{ Averages from Previous Runs for Comparison } \\
\hline & TC13 & Clean & 0.011 & 0.013 & 87.8 \\
\hline & TC12 & Semi-Dirty & 0.011 & N.M. ${ }^{1}$ & N.M. ${ }^{1}$ \\
\hline & TC11 & Clean & 0.013 & 0.023 & 84.5 \\
\hline & TC10 & Clean & 0.010 & N.M. ${ }^{1}$ & N.M. ${ }^{1}$ \\
\hline & TCO9 & Semi-Dirty & 0.008 & 0.006 & 93.3 \\
\hline & TCO8 & Semi-Dirty & 0.010 & N.M. ${ }^{1}$ & N.M. ${ }^{1}$ \\
\hline & TCO7 & Clean & N.M. ${ }^{1}$ & N.M. ${ }^{1}$ & N.M. ${ }^{1}$ \\
\hline & TC06 & Semi-Dirty & 0.010 & 0.020 & 82.5 \\
\hline
\end{tabular}


Table 3.2-3

Physical Properties of TC14 In Situ Samples and Hopper Samples Used for RAPTOR

\begin{tabular}{|c|c|c|c|c|c|c|c|c|}
\hline Sample ID & $\begin{array}{l}\text { Run } \\
\text { No. }\end{array}$ & Sample Date & $\begin{array}{c}\text { Bulk } \\
\text { Density } \\
\text { g/cc }\end{array}$ & $\begin{array}{c}\text { True } \\
\text { Density } \\
\text { g/cc }\end{array}$ & $\begin{array}{c}\text { Uncompacted } \\
\text { Bulk Porosity } \\
\%\end{array}$ & $\begin{array}{c}\text { Specific } \\
\text { Surface Area } \\
\mathrm{m}^{2} / \mathrm{g}\end{array}$ & $\begin{array}{c}\text { Mass-Median } \\
\text { Diameter } \\
\mu \mathrm{m}\end{array}$ & $\begin{array}{l}\text { Loss on } \\
\text { Ignition } \\
\text { Wt \% }\end{array}$ \\
\hline \multicolumn{9}{|c|}{ In-Situ Samples } \\
\hline \multicolumn{9}{|c|}{ Air-Blown } \\
\hline AB14563 & 1 & $02 / 20 / 04$ & 0.37 & 2.18 & 83.0 & 115 & 22.2 & 40.50 \\
\hline AB14564 & 2 & $02 / 21 / 04$ & 0.34 & 2.35 & 85.5 & 156 & 25.0 & 31.36 \\
\hline AB14565 & 3 & $02 / 23 / 04$ & 0.43 & 2.31 & 81.4 & 92 & 18.2 & 39.69 \\
\hline$A B 14566$ & 4 & $02 / 25 / 04$ & 0.46 & 2.32 & 80.2 & 127 & 20.1 & 47.29 \\
\hline AB14567 & 5 & $02 / 26 / 04$ & 0.47 & 2.22 & 78.8 & 101 & 21.9 & 32.01 \\
\hline \multicolumn{9}{|c|}{ Oxygen-Blown } \\
\hline AB14568 & 6 & $02 / 27 / 04$ & 0.37 & 2.42 & 84.7 & 122 & 25.9 & 26.99 \\
\hline AB14569 & 7 & $02 / 28 / 04$ & 0.21 & 2.23 & 90.6 & 204 & 14.1 & 39.47 \\
\hline \multicolumn{3}{|c|}{ Average (Air- \& Oxygen-Blown) } & 0.38 & 2.29 & 83.5 & 131 & 21.0 & 36.76 \\
\hline \multicolumn{9}{|c|}{ Hopper Samples Used for Lab Drag Measurements (AII Air-Blown) } \\
\hline AB14613 & 1 & $02 / 21 / 04$ & 0.63 & 2.44 & 74.1 & 75 & 51.1 & 21.94 \\
\hline AB14614 & 2 & $02 / 25 / 04$ & 0.38 & 2.21 & 82.7 & 90 & 18.6 & 41.43 \\
\hline AB14623 & 3 & $02 / 26 / 04$ & 0.39 & 2.35 & 83.2 & 135 & 15.8 & 38.53 \\
\hline \multicolumn{3}{|l|}{ Average } & 0.47 & 2.33 & 80.0 & 100 & 28.5 & 33.97 \\
\hline
\end{tabular}


Table 3.2-4

Chemical Composition of TC14 In Situ Samples and Hopper Samples Used for RAPTOR

\begin{tabular}{|c|c|c|c|c|c|c|c|c|}
\hline Sample ID & $\begin{array}{l}\text { Run } \\
\text { No. }\end{array}$ & Sample Date & $\begin{array}{c}\mathrm{CaCO}_{3} \\
\mathrm{Wt} \%\end{array}$ & $\begin{array}{c}\mathrm{CaS} \\
\mathrm{Wt} \%\end{array}$ & $\begin{array}{c}\mathrm{CaO} \\
\mathrm{Wt} \%\end{array}$ & $\begin{array}{c}\text { Non-Carbonate } \\
\text { Carbon } \\
\text { Wt \% }\end{array}$ & $\begin{array}{c}\text { Inerts } \\
\text { (Ash/Sand) } \\
\text { Wt \% }\end{array}$ & $\begin{array}{l}\text { Loss on } \\
\text { Ignition } \\
\text { Wt \% }\end{array}$ \\
\hline \multicolumn{9}{|c|}{ In-Situ Samples } \\
\hline \multicolumn{9}{|c|}{ Air-Blown } \\
\hline AB14563 & 1 & $02 / 20 / 04$ & 4.61 & 0.94 & 3.94 & 38.95 & 51.56 & 40.50 \\
\hline AB14564 & 2 & $02 / 21 / 04$ & 4.18 & 0.85 & 6.92 & 31.17 & 56.88 & 31.36 \\
\hline AB14565 & 3 & $02 / 23 / 04$ & 4.95 & 0.83 & 2.59 & 41.85 & 49.79 & 39.69 \\
\hline AB14566 & 4 & 02/25/04 & 2.73 & 0.60 & 5.25 & 42.92 & 48.50 & 47.29 \\
\hline AB14567 & 5 & $02 / 26 / 04$ & 3.57 & 0.45 & 2.24 & 23.34 & 70.40 & 32.01 \\
\hline \multicolumn{9}{|c|}{ Oxygen-Blown } \\
\hline AB14568 & 6 & $02 / 27 / 04$ & 4.59 & 0.02 & 6.41 & 22.67 & 66.31 & 26.99 \\
\hline AB14569 & 7 & $02 / 28 / 04$ & 6.20 & 0.25 & 5.05 & 33.20 & 55.31 & 39.47 \\
\hline \multicolumn{3}{|c|}{ Average (Air- \& Oxygen-Blown) } & 4.41 & 0.56 & 4.63 & 33.44 & 56.96 & 36.76 \\
\hline \multicolumn{9}{|c|}{ Hopper Samples Used for Lab Drag Measurements (All Air-Blown) } \\
\hline AB14613 & 1 & $02 / 21 / 04$ & 3.64 & 0.47 & 3.76 & 24.61 & 67.52 & 21.94 \\
\hline $\mathrm{AB} 14614$ & 2 & $02 / 25 / 04$ & 4.82 & 0.56 & 2.72 & 34.88 & 57.02 & 41.43 \\
\hline AB14623 & 3 & $02 / 26 / 04$ & 5.30 & 3.58 & 13.42 & 36.54 & 41.16 & 38.53 \\
\hline \multicolumn{3}{|l|}{ Average } & 4.58 & 1.54 & 6.63 & 32.01 & 55.23 & 33.97 \\
\hline
\end{tabular}


Table 3.2-5

Physical Properties of TC14 Residual Dustcake

\begin{tabular}{|l|c|c|c|c|c|c|c|}
\hline Sample ID & Sample Date & $\begin{array}{c}\text { Bulk } \\
\text { Density } \\
\text { g/cc }\end{array}$ & $\begin{array}{c}\text { True } \\
\text { Density } \\
\mathrm{g} / \mathrm{cc}\end{array}$ & $\begin{array}{c}\text { Uncompacted } \\
\text { Bulk Porosity } \\
\%\end{array}$ & $\begin{array}{c}\text { Specific } \\
\text { Surface Area } \\
\mathrm{m}^{2} / \mathrm{g}\end{array}$ & $\begin{array}{c}\text { Mass-Median } \\
\text { Diameter } \\
\mu \mathrm{m}\end{array}$ & $\begin{array}{c}\text { Loss on } \\
\text { Ignition } \\
\mathrm{Wt}\end{array}$ \\
\hline AB14576 & $03 / 03 / 04$ & 0.30 & 2.56 & 88.3 & 53 & 6.0 & 22.94 \\
\hline \multicolumn{7}{|c|}{ Top Plenum } \\
\hline AB14577 & $03 / 03 / 04$ & 0.26 & 2.48 & 89.5 & 92 & 7.4 & 37.66 \\
\hline
\end{tabular}

Table 3.2-6

Chemical Composition of TC14 Residual Dustcake

\begin{tabular}{|c|c|c|c|c|c|c|c|}
\hline Sample ID & Sample Date & $\begin{array}{c}\mathrm{CaCO}_{3} \\
\mathrm{Wt} \%\end{array}$ & $\begin{array}{c}\mathrm{CaS} \\
\mathrm{Wt} \%\end{array}$ & $\begin{array}{c}\mathrm{CaO} \\
\mathrm{Wt} \%\end{array}$ & $\begin{array}{c}\text { Non-Carbonate } \\
\text { Carbon } \\
\mathrm{Wt} \%\end{array}$ & $\begin{array}{c}\text { Inerts } \\
\text { (Ash/Sand) } \\
\mathrm{Wt} \%\end{array}$ & $\begin{array}{c}\text { Loss on } \\
\text { Ignition } \\
\text { Wt \% }\end{array}$ \\
\hline AB14576 & $03 / 03 / 04$ & 4.14 & 2.18 & 6.75 & 19.88 & 67.05 & 22.94 \\
\hline \multicolumn{7}{|c|}{ Bottom Plenum } \\
\hline AB14577 & $03 / 03 / 04$ & 4.82 & 1.39 & 7.95 & 33.06 & 52.78 & 37.66 \\
\hline
\end{tabular}


Table 3.2.7

TC14 Transient Drag Determined from PCD $\triangle \mathrm{P}$ and from RAPTOR

\begin{tabular}{|c|c|c|c|c|c|c|c|c|c|}
\hline \multirow{2}{*}{ Run No. } & \multirow{2}{*}{$\begin{array}{c}\Delta \mathrm{P} / \Delta \mathrm{t} \\
\text { inwc/min }\end{array}$} & \multirow{2}{*}{$\begin{array}{l}\Delta(\mathrm{AL}) / \Delta \mathrm{t}, \\
\mathrm{lb} / \mathrm{ft}^{2} / \mathrm{min}\end{array}$} & \multirow{2}{*}{$\begin{array}{l}\mathrm{FV}, \\
\mathrm{ft} / \mathrm{min}\end{array}$} & \multirow{2}{*}{$\begin{array}{c}\mathrm{MMD}, \\
\mu \mathrm{m}\end{array}$} & \multirow{2}{*}{ NCC, $\%$} & \multicolumn{4}{|c|}{ Drag, inwc/(lb/ft $\left.{ }^{2}\right) /(\mathrm{ft} / \mathrm{min})$} \\
\hline & & & & & & PCD & PCD@RT & RAPTOR $^{1}$ & RAPTOR $^{2}$ \\
\hline \multicolumn{10}{|c|}{ Air-Blown - PRB } \\
\hline 1 & 2.64 & 0.039 & 3.85 & 22.2 & 39.0 & 69 & 41 & 41 & 67 \\
\hline 2 & 2.88 & 0.032 & 3.48 & 25.0 & 31.2 & 91 & 55 & 32 & 59 \\
\hline 3 & 2.96 & 0.039 & 3.76 & 18.2 & 41.9 & 76 & 45 & 53 & 81 \\
\hline 4 & 4.16 & 0.067 & 3.72 & 20.1 & 42.9 & 62 & 36 & 49 & 73 \\
\hline 5 & 3.35 & 0.039 & 3.46 & 21.9 & 23.3 & 86 & 50 & 31 & 67 \\
\hline \multicolumn{10}{|c|}{ Oxygen-Blown - PRB } \\
\hline 6 & 2.52 & 0.028 & 3.30 & 25.9 & 22.7 & 90 & 56 & 26 & 57 \\
\hline 7 & 2.20 & 0.028 & 2.73 & 14.1 & 33.2 & 78 & 49 & 59 & 104 \\
\hline
\end{tabular}

Nomenclature:

$\Delta \mathrm{P} \mid \Delta \mathrm{t}=$ rate of pressure drop rise during particulate sampling run, inwc/min.

$\Delta(\mathrm{AL}) \mid \Delta \mathrm{t}=$ rate of increase in areal loading during sampling run, $\mathrm{lb} / \mathrm{min} / \mathrm{ft}^{2}$.

$\mathrm{FV}$ = average PCD face velocity during particulate sampling run, $\mathrm{ft} / \mathrm{min}$.

MMD = mass median diameter of in situ particulate sample, $\mu \mathrm{m}$.

NCC $=$ non-carbonate carbon.

$\mathrm{RT}=$ room temperature, $77^{\circ} \mathrm{F}\left(25^{\circ} \mathrm{C}\right)$.

RAPTOR = resuspended ash permeability tester. 


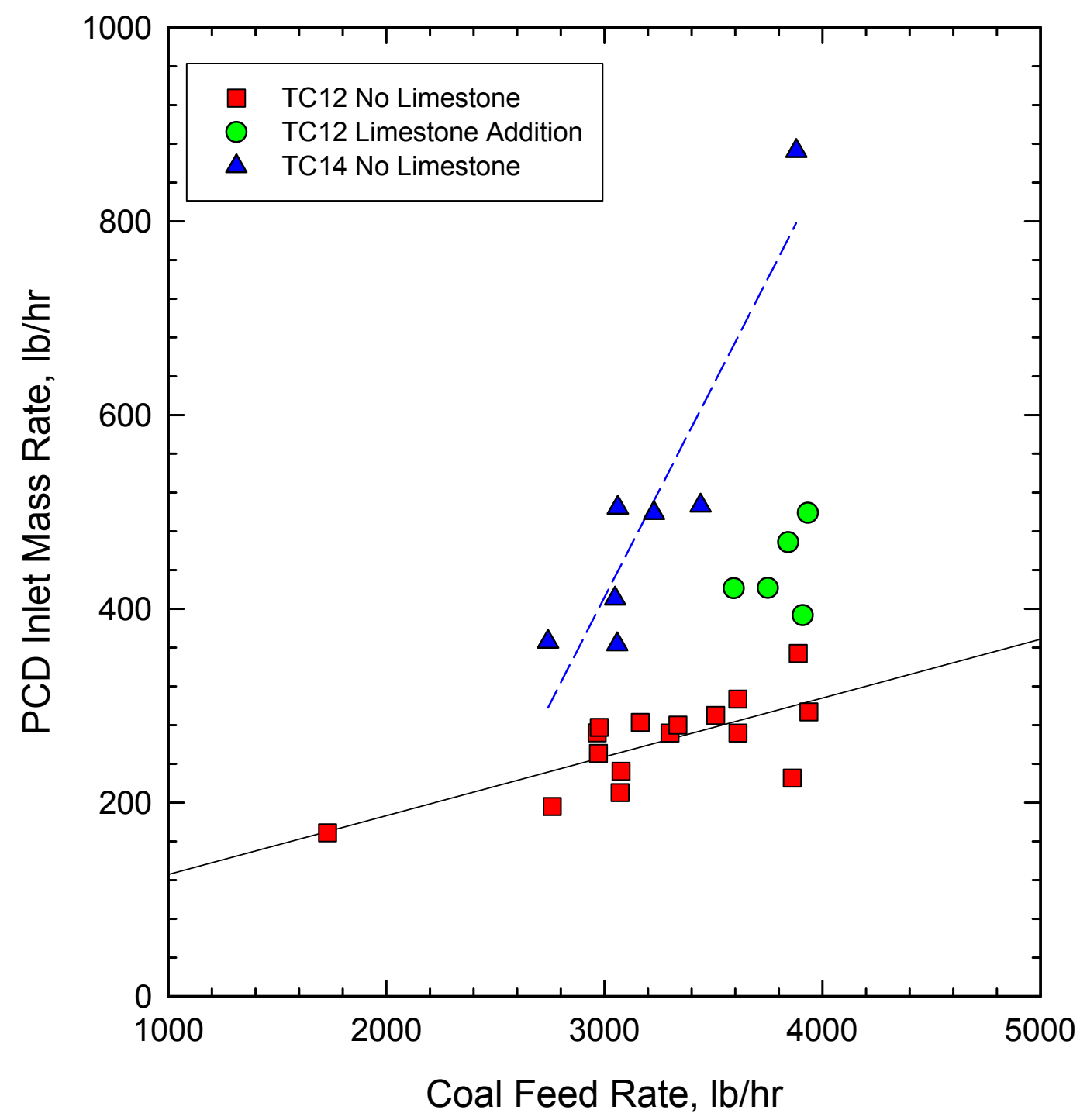

Figure 3.2-1 PCD Inlet Particle Concentration as a Function of Coal Feed Rate 


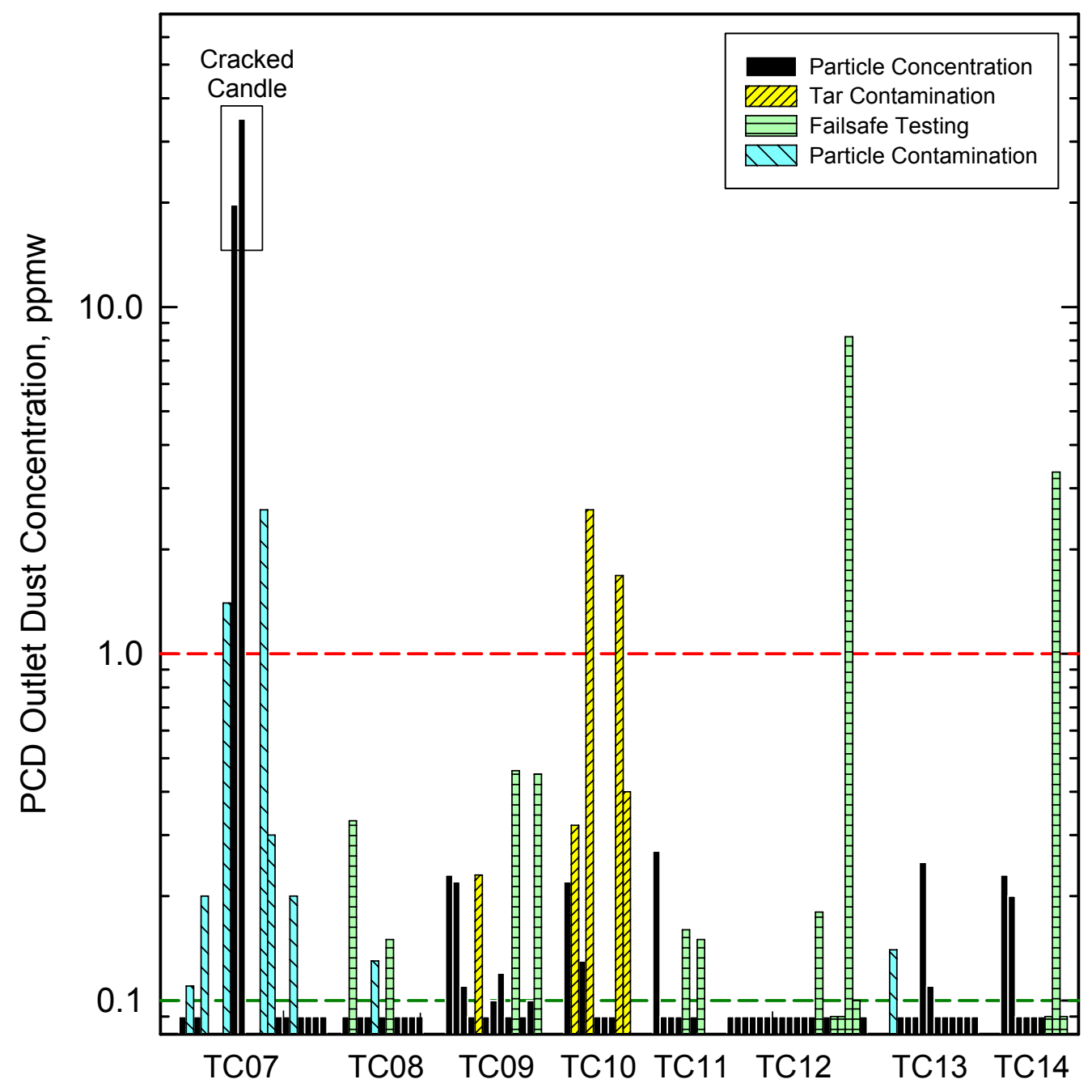

Figure 3.2-2 PCD Outlet Dust Concentrations for Recent Gasification Runs 


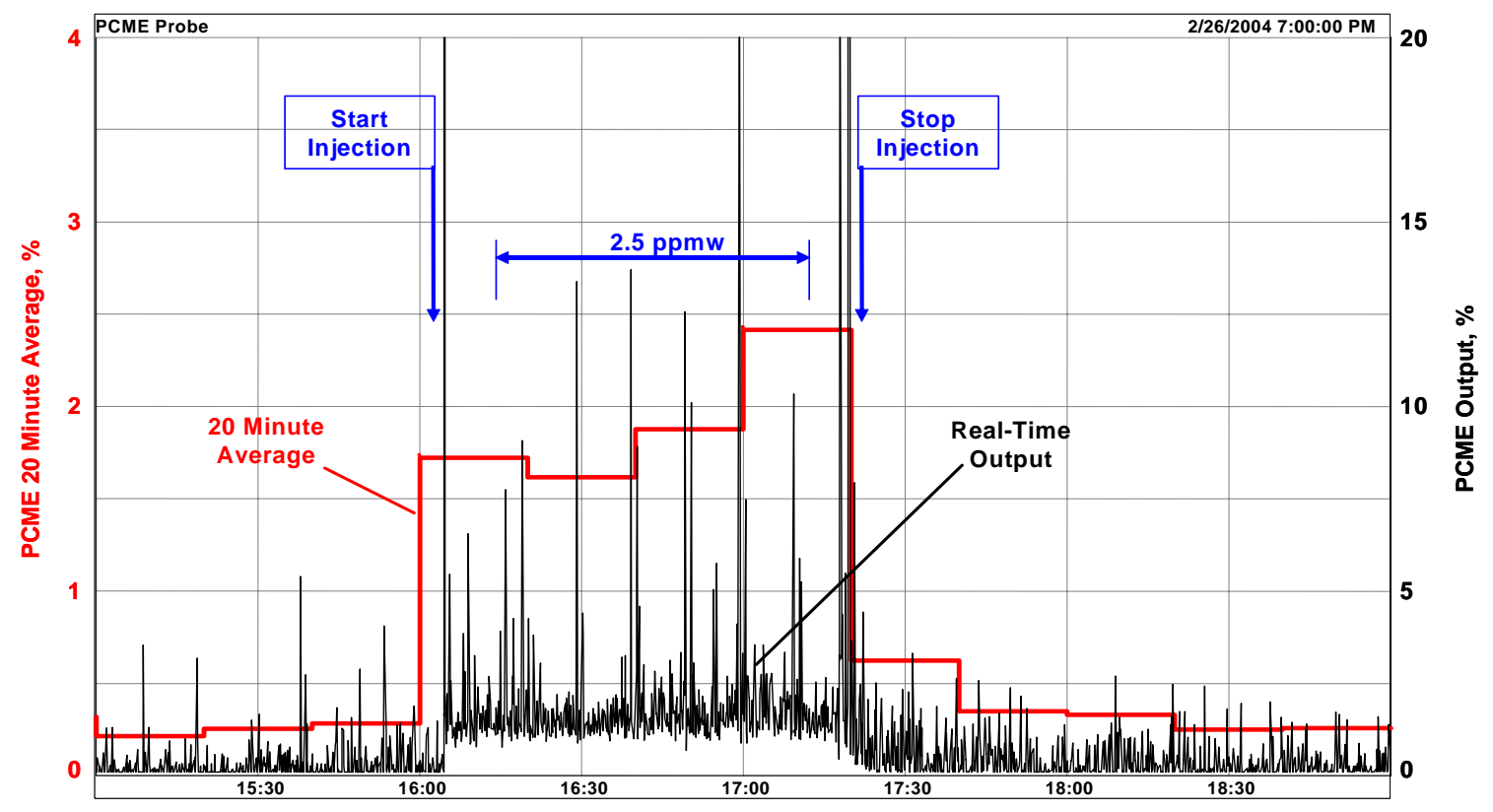

Figure 3.2-3. PCME Output During PCD Outlet Dust Injection Test

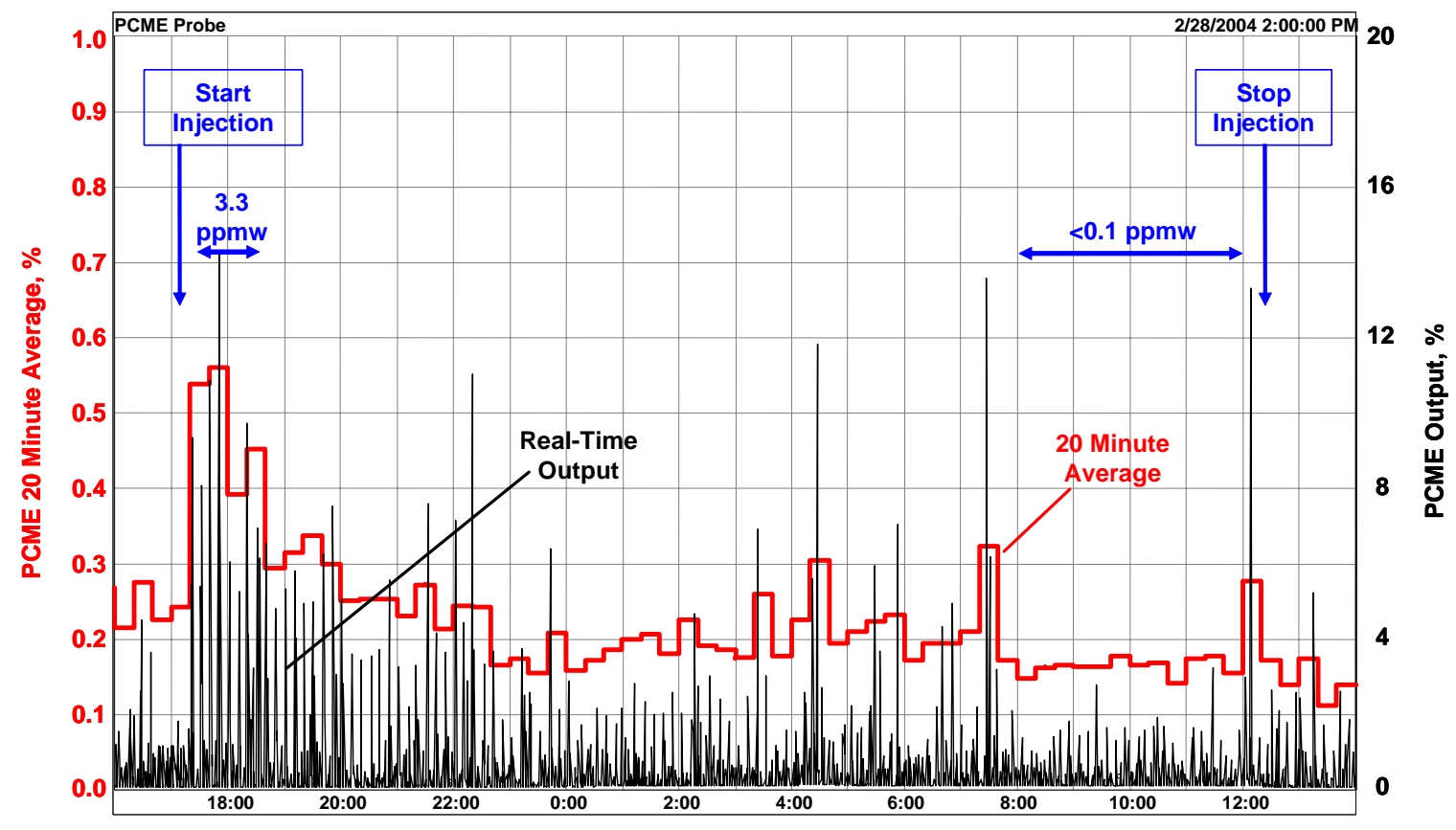

Figure 3.2-4 PCME Output during CeraMem Failsafe Test 


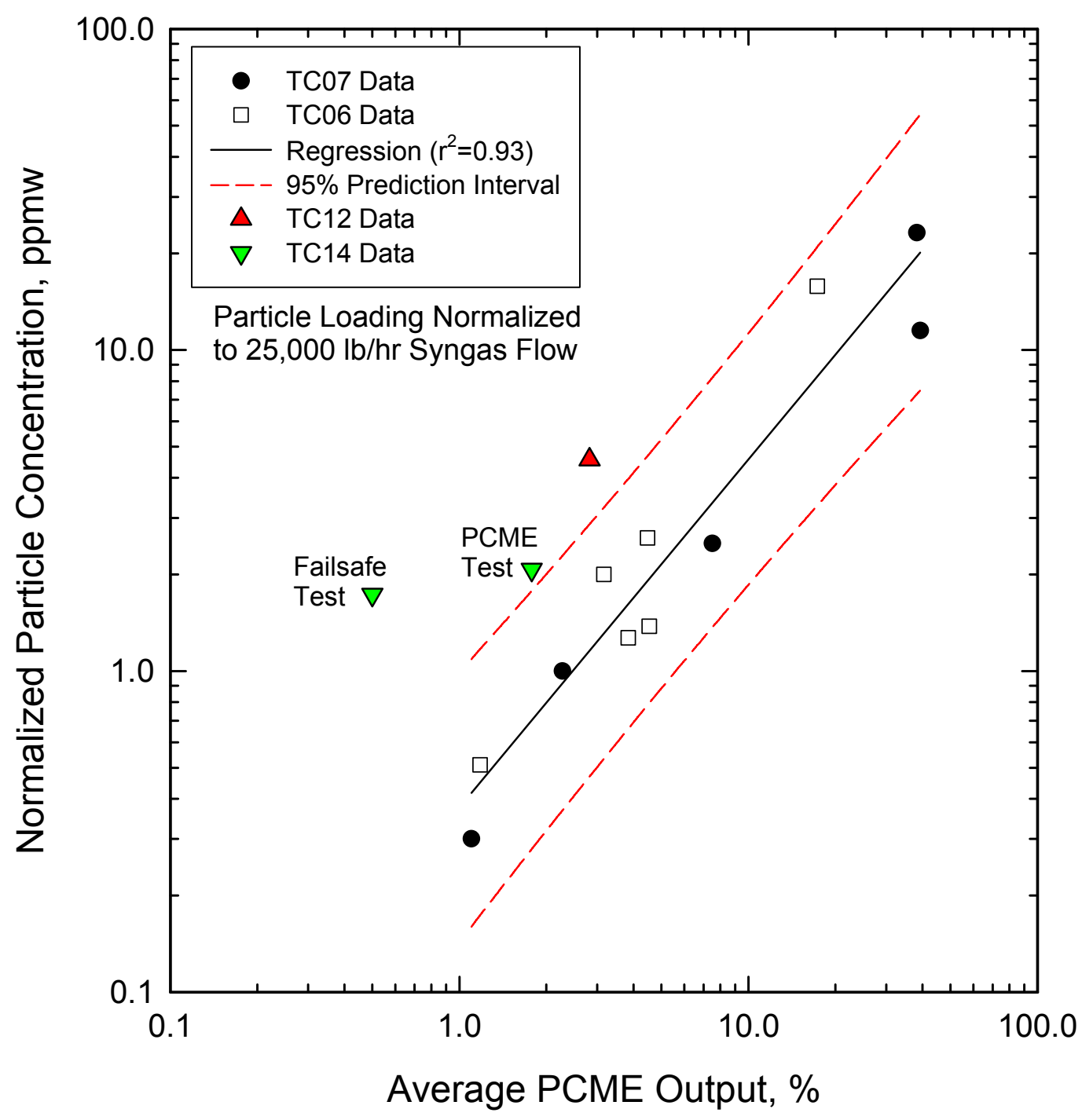

Figure 3.2-5 Relationship Between PCME Output and Actual Particle Concentration 


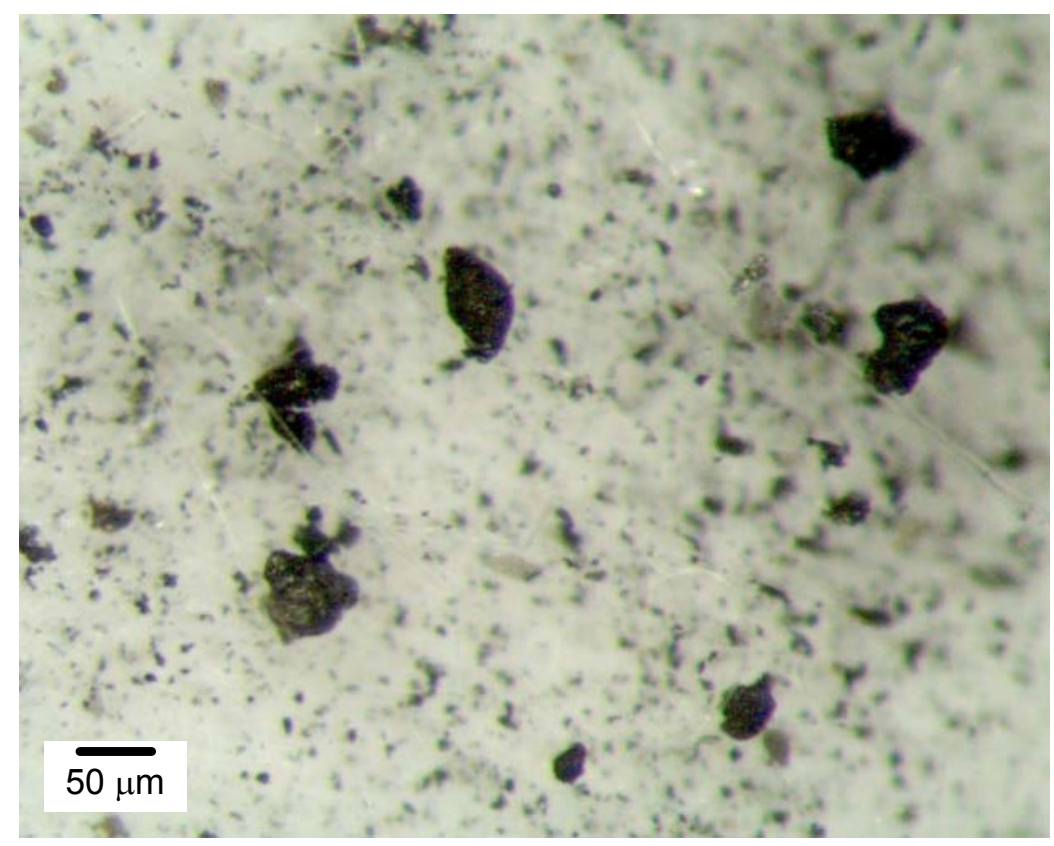

Figure 3.2-6 Micrograph of Sample Filter from PCME Injection Test (2.5 ppmw Actual, PCME Output 1.8\%)

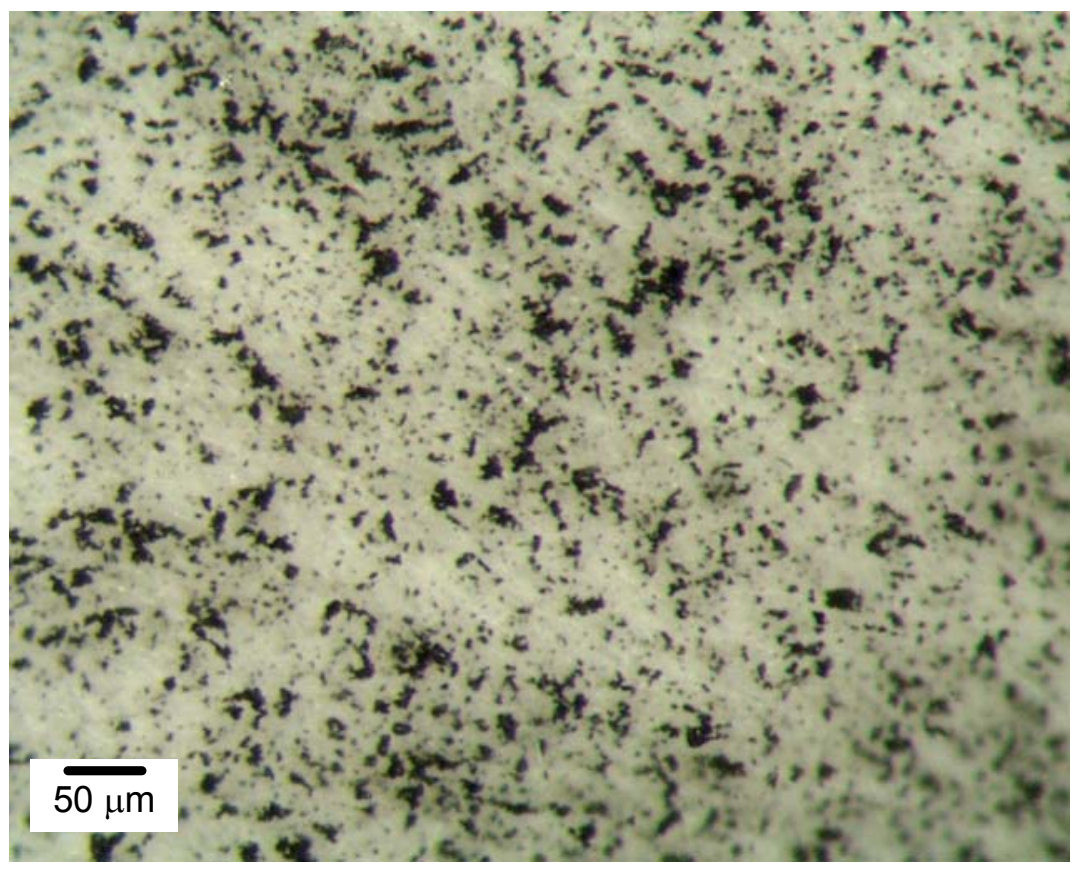

Figure 3.2-7 Micrograph of Sample Filter from CeraMem Failsafe Test (3.34 ppmw Actual, PCME Output 0.5\%) 


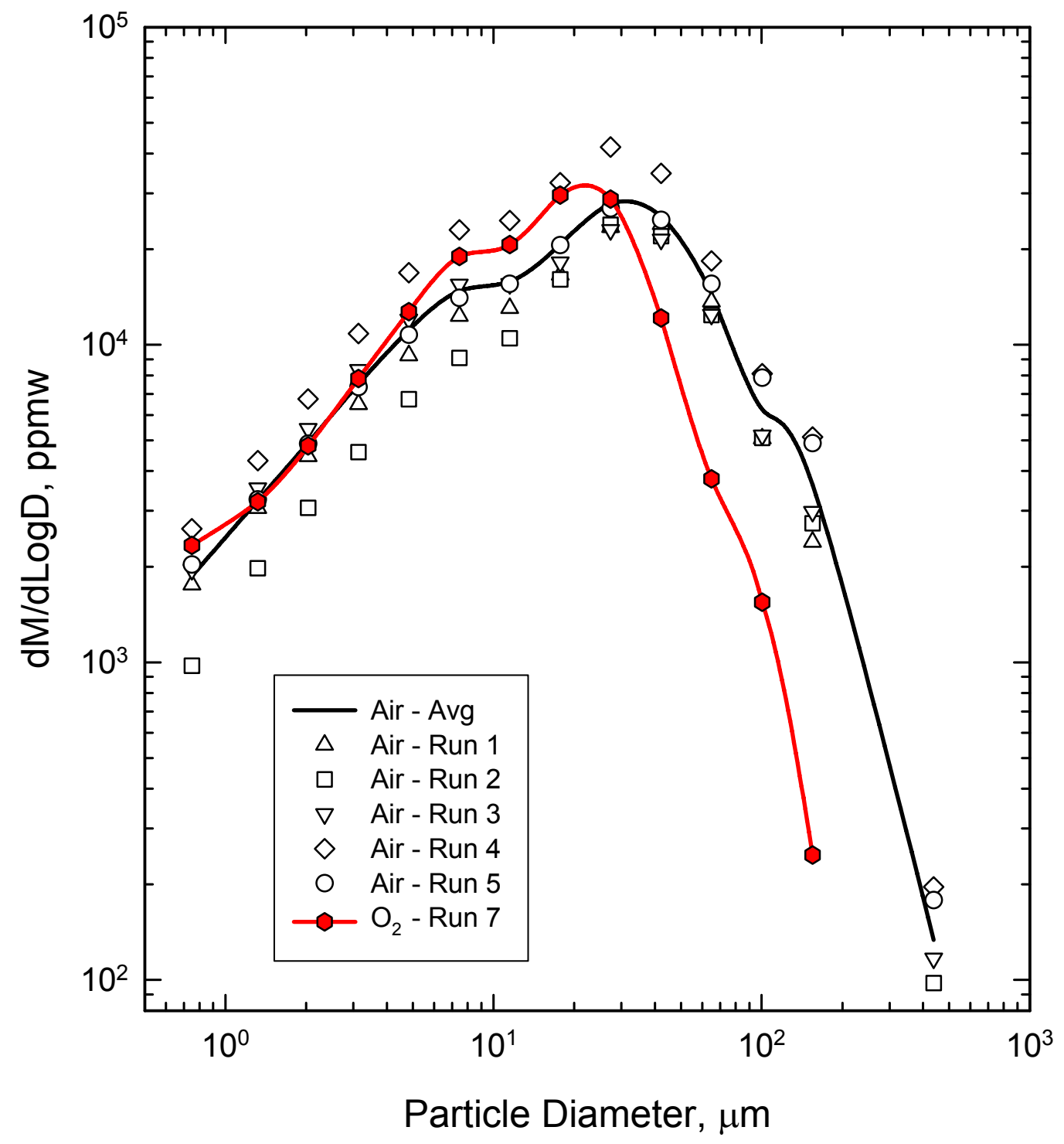

Figure 3.2-8 Comparison of Average PCD Inlet Particle Size Distributions on Mass Basis 


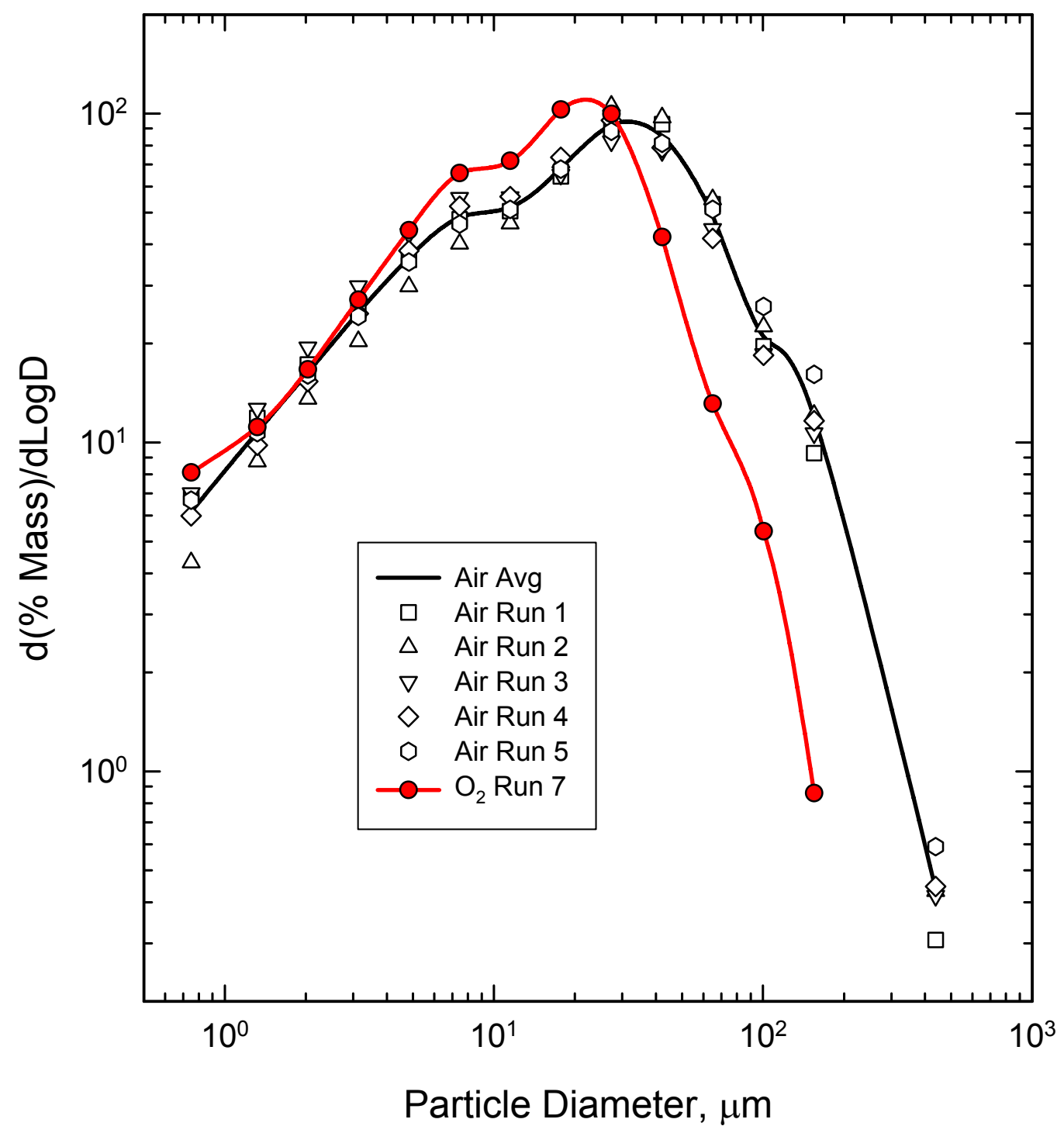

Figure 3.2-9 Comparison of Average PCD Inlet Particle Size Distributions on Percentage Basis 


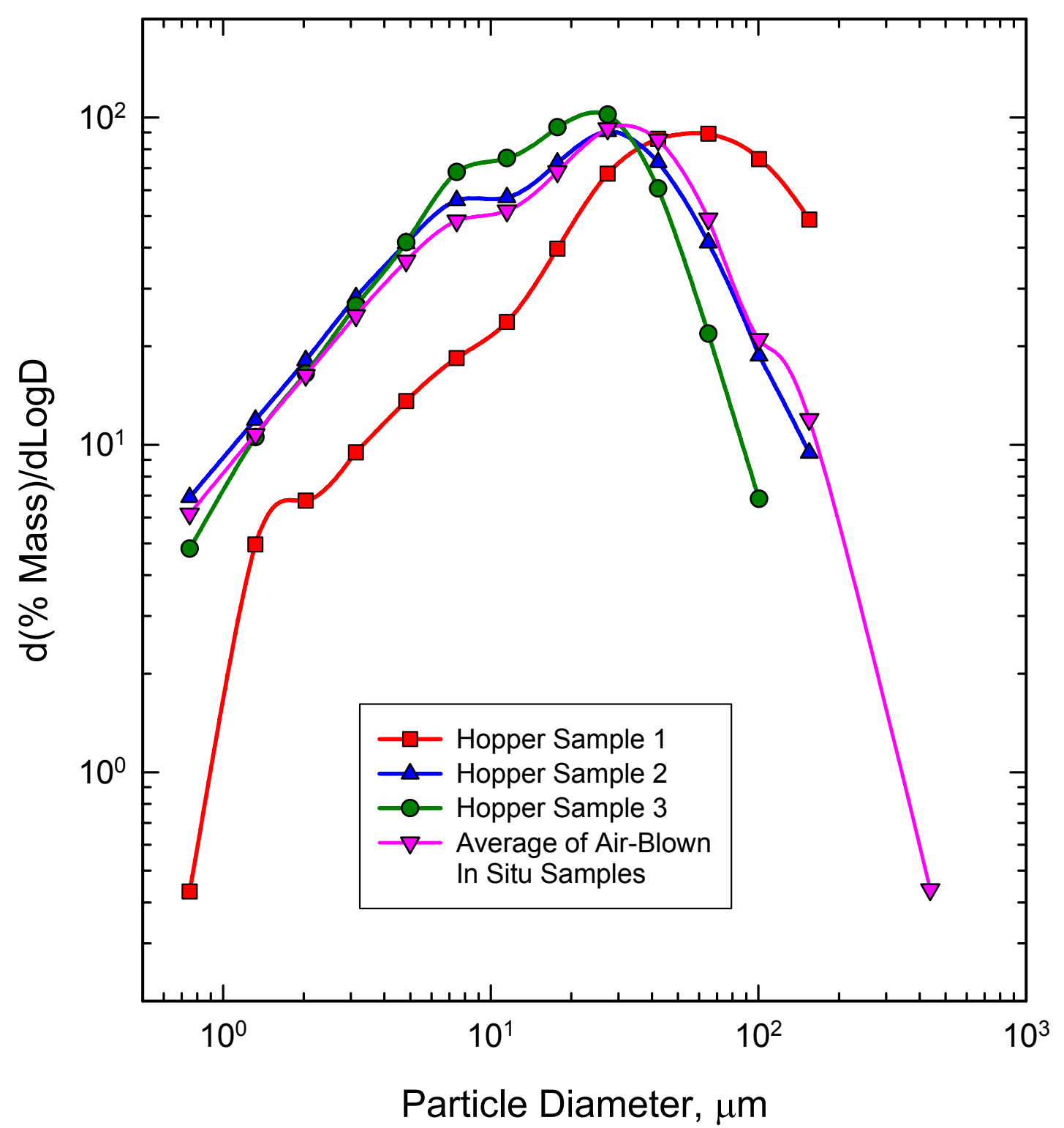

Figure 3.2-10 Comparison of In Situ and Hopper Particle Size Distributions 


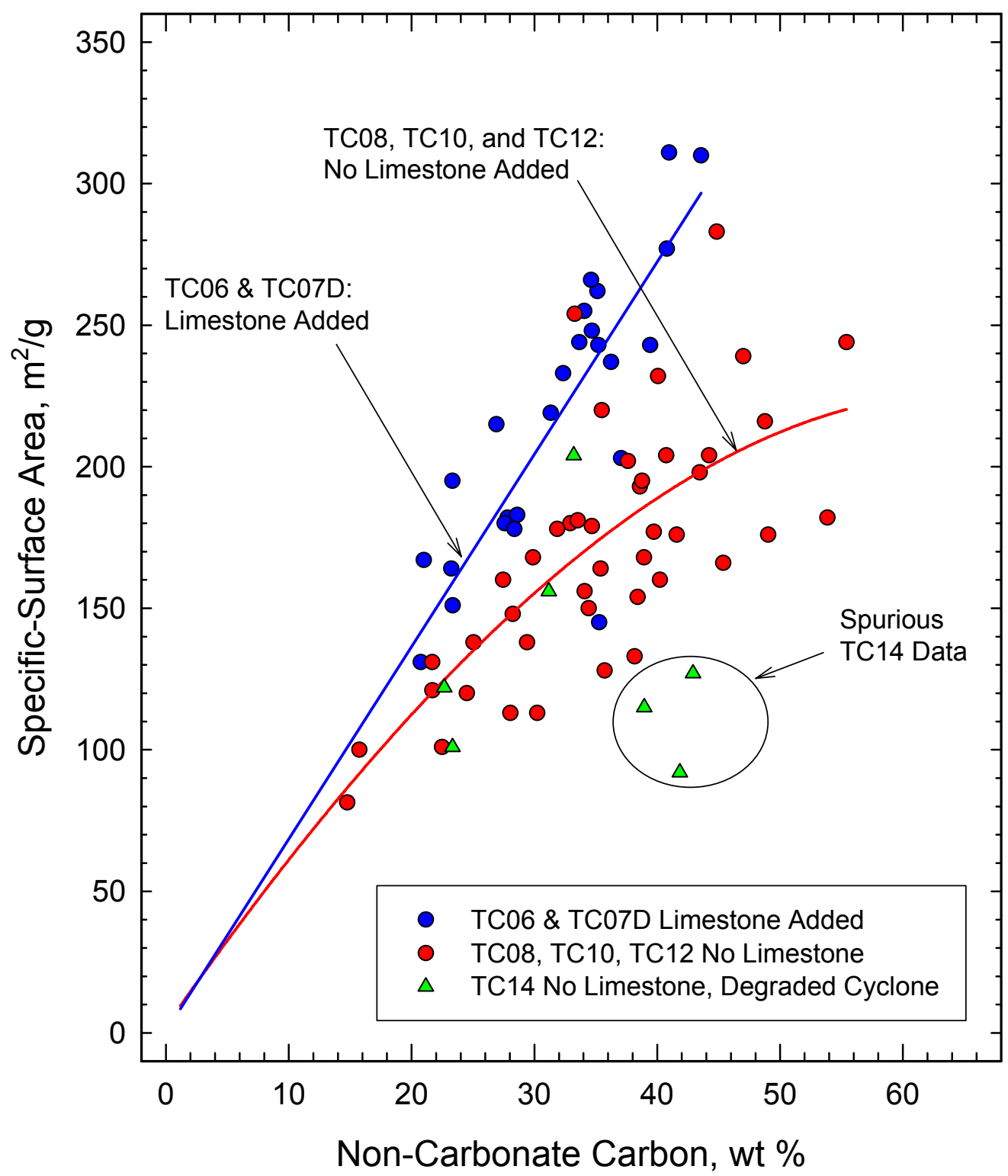

Figure 3.2-11 Specific Surface Area versus Carbon Content of In Situ Samples 


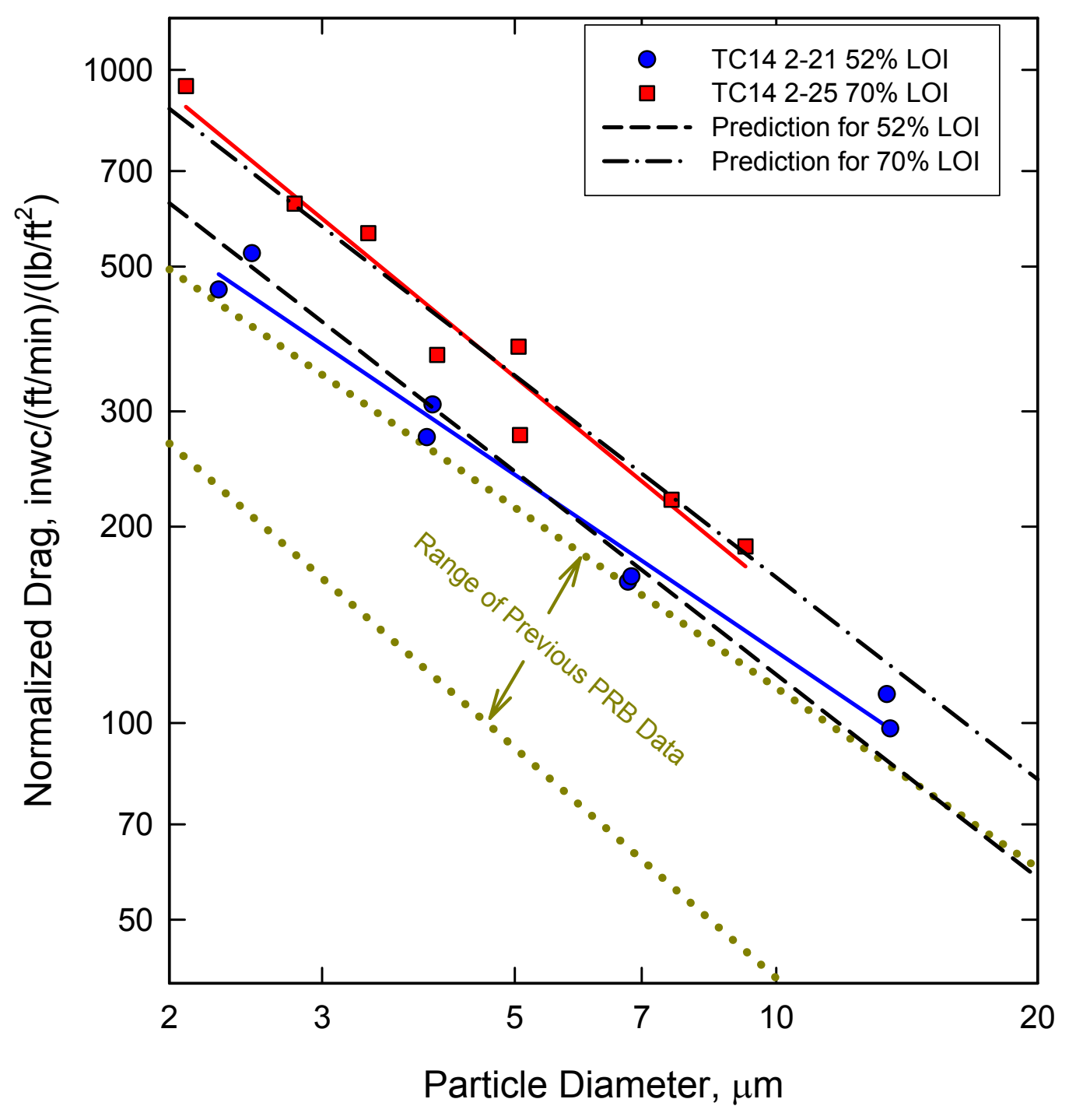

Figure 3.2-12 Laboratory Measurements of TC14 Dustcake Drag versus Particle Size

Figure 3.2-12 Laboratory Measurements of TC14 Dustcake Drag versus Particle Size 


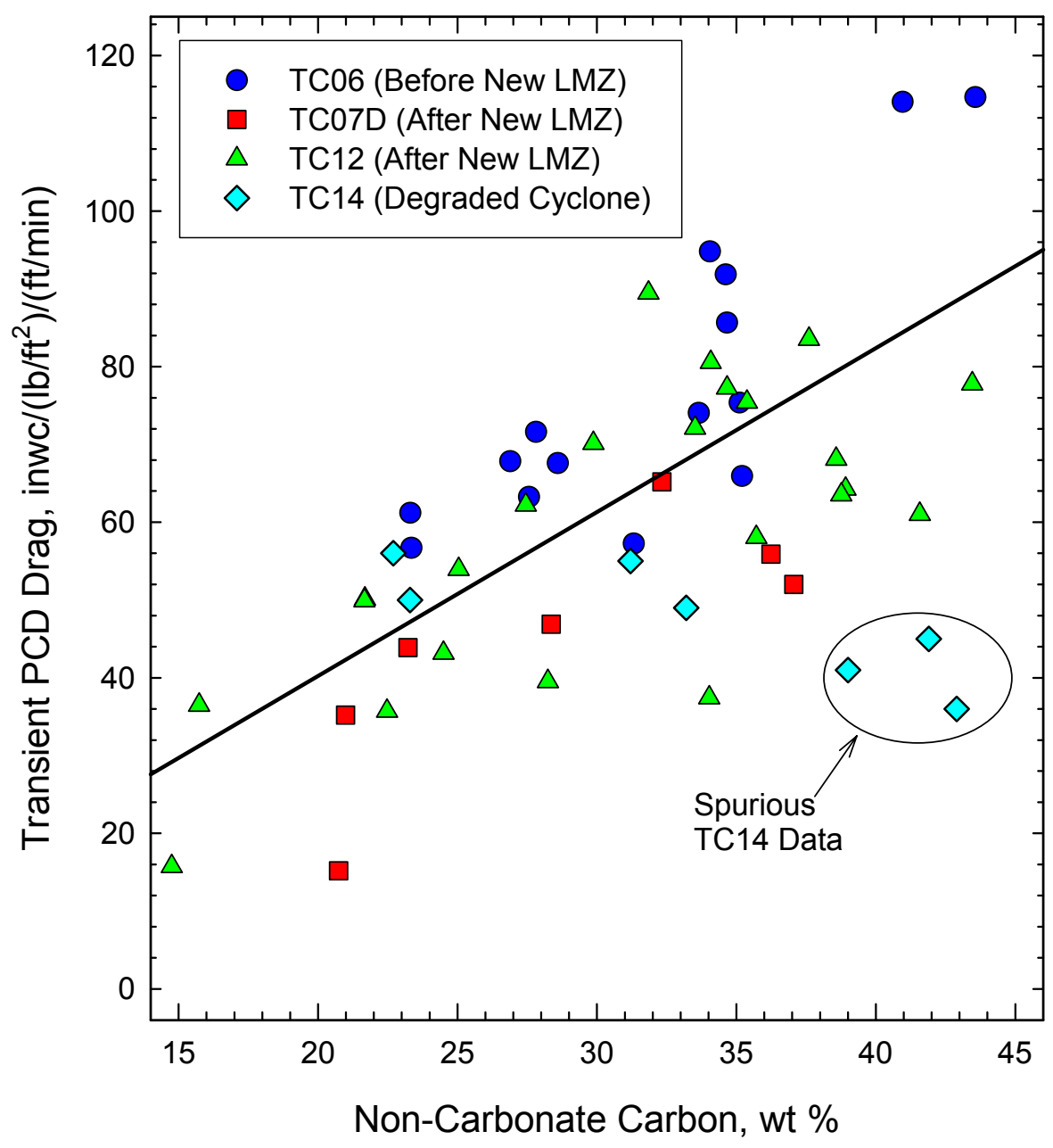

Figure 3.2-13 PCD Transient Drag Versus Carbon Content of In Situ Samples 


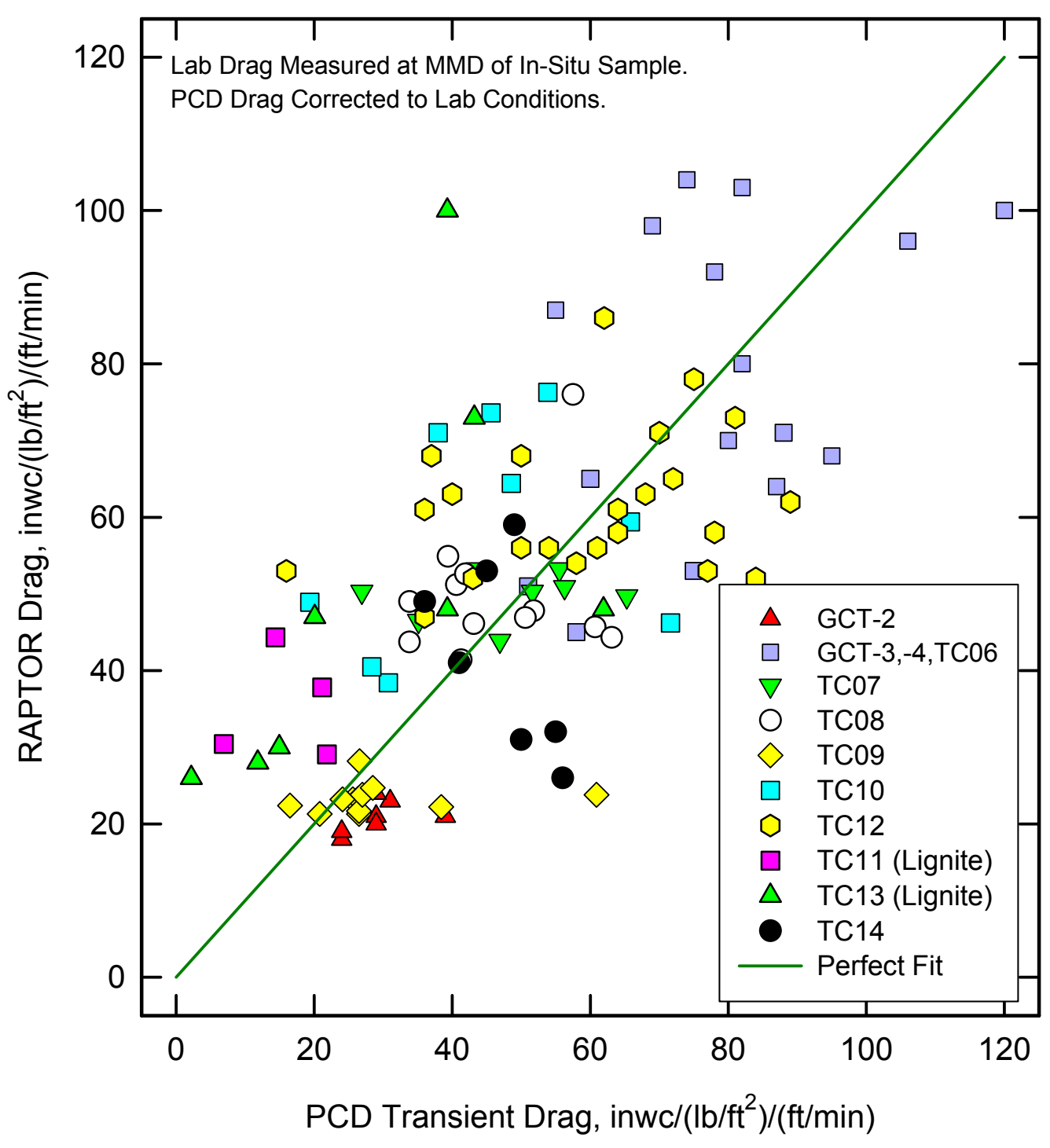

Figure 3.2-14 Comparison of PCD Transient Drag with Laboratory Measurements 


\section{APPENDIX A1 OPERATION HISTORY}

Conversion of the Transport Reactor train to gasification mode of operation was performed from May to September 1999. The first gasification test run, GCT1, was a 233-hour test run to commission the Transport Gasifier and to characterize the limits of operational parameter variations. GCT1 was started on September 9, 1999, with the first part completed on September 15, 1999. The second part of GCT1 was started on December 7, 1999, and completed on December 15, 1999. This test run provided the data necessary for preliminary analysis of gasifier operations and for identification of necessary modifications to improve equipment and process performance. Five different feed combinations of coal and sorbent were tested to gain a better understanding of the gasifier solids collection system efficiency.

GCT2, a 218-hour characterization test run, was started on April 10, 2000, and completed on April 27, 2000. Additional data was taken to analyze the effect of different operating conditions on gasifier performance and operability. A blend of several Powder River Basin (PRB) coals was used with Longview limestone from Alabama. In the outage following GCT2, the Transport Gasifier underwent a major modification to improve the operation and performance of the gasifier solids collection system. The most fundamental change was the addition of the loop seal underneath the primary cyclone.

GCT3 was a 184-hour characterization with the primary objective to commission the loop seal. A hot solids circulation test (GCT3A) was started on December 1, 2000, and completed December 15, 2000. After a one-month outage to address maintenance issues with the main air compressor, GCT3 was continued. The second part of GCT3 was started on January 20, 2001, and completed on February 1, 2001. A blend of several PRB coals was used with Bucyrus limestone from Ohio. The loop seal performed well, allowing much higher solids circulation rates and higher coal feed rates. Also, the improved collection efficiency of the cyclone resulted in lower relative solids loading to the PCD and higher char retention in the gasifier.

GCT4 was a 242-hour characterization test, started on March 7, 2001, and completed on March 30, 2001. A blend of several PRB coals with Bucyrus limestone from Ohio was used. More experience was gained with the loop seal operations and additional data was collected to better understand gasifier performance.

TC06 was a 1025-hour test campaign and was started on July 4, 2001, and completed on September 24, 2001. A blend of several PRB coals with Bucyrus limestone from Ohio was used. Due to its length and stability of operation, the TC06 test run provided valuable data necessary to analyze long term gasifier operations and to identify necessary modifications to improve equipment and process performance, as well as progressing the goal of many thousands of hours of filter element exposure.

TC07 was a 442-hour test campaign and was started on December 11, 2001, and completed on April 5, 2002. A blend of several PRB coals and a bituminous coal from the Calumet mine in Alabama were tested with Bucyrus limestone from Ohio. Due to operational difficulties with the gasifier (stemming from instrumentation problems) the unit was taken 
offline several times. PCD operations were relatively stable considering the numerous gasifier upsets.

TC08 was a 365-hour test campaign to commission the gasifier in oxygen blown mode of operation and was started on June 9, 2002, and completed on June 29, 2002. A blend of several PRB coals were tested in air blown, enriched air and oxygen blown modes of operation. The transition from different modes of operation was smooth and it was demonstrated that the full transition could be made within 15 minutes. Both gasifier and PCD operations were stable during the test run.

TC09 was a 309-hour test campaign to characterize the gasifier and PCD operations in air and oxygen blown mode of operations using a bituminous coal. TC09 was started on September 3, 2002, and completed on September 26, 2002. A bituminous coal from the Sufco mine in Utah was successfully tested in air blown and oxygen blown modes of operation. Both gasifier and PCD operations were stable during the test run.

TC10 was a 416-hour test campaign to conduct long-term tests to evaluate the gasifier and PCD operations in oxygen blown mode of operations using a blend of several PRB coals. TC10 was started on November 16, 2002, and completed on December 18, 2002. Despite problems with the coal mills, coal feeder, pressure tap nozzles and the standpipe, the gasifier did experience short periods of stability during oxygen blown operations. During these periods, the syngas quality was high. During TC10, over 609 tons of PRB subbituminous coals were gasified.

TC11 was a 192-hour test campaign to conduct short-term tests to evaluate the gasifier and PCD operations in air and oxygen blown mode of operations using Falkirk lignite from North Dakota. TC11 was started on April 7, 2003, and completed on April 18, 2003. During TC11, the lignite proved difficult to feed due to difficulties in the mill operation as a result of the high moisture content in the fuel. However, the gasifier operated well using lignite, with high circulation rates, riser densities and stable temperature profiles. Consequently, the temperature distribution in both the mixing zone and the riser was more uniform than in any previous test run, varying less than $10^{\circ} \mathrm{F}$ throughout the gasifier.

TC12 was a 733-hour test campaign to conduct short-term tests to evaluate the gasifier and PCD operations in air and oxygen blown mode of operations using a blend of several PRB coals. TC12 was started on May 16, 2003, and completed on July 14, 2003. Primary objectives for TC12 was the commissioning a new gas cleanup system and operating a fuel cell on coal-derived syngas from the Transport Gasifier. The fuel cell system and gas cleanup system both performed well during the testing.

TC13 was a 501-hour test campaign to conduct short-term tests to evaluate gasifier, PSB, and PCD operations in air blown mode of operations using a blend of several PRB coals as well as to conduct short-term tests to evaluate gasifier and PCD operations using two different types of lignite coal from the Freedom Mine in North Dakota. One type of lignite had a high ash sodium content, while the other types had a low ash sodium content. TC13 was started on September 30, 2003, and completed on November 2, 2003. PSB testing 
lasted for a total of about six hours. While successful, the hydraulic system on the turbine cranking motor failed and prevented further PSB testing. The low sodium lignite testing went well, but lowering the gasifier temperature to below $1500^{\circ} \mathrm{F}$ was necessary to prevent deposits from forming with the high sodium lignite.

TC14, the subject of this report, was a 214-hour test campaign to conducts short-term tests to evaluate the gasifier, PSB, and PCD operations using a blend of several PRB coals. TC14 began on February 16, 2004, and ended on February 28, 2004. The PSB testing lasted for a total of about 17 hours at syngas flow rates up to 17,000 pph, contributing about 82 percent of the total energy to the PSB. Another major goal of TC14 was to commission the CFAD unit. The new system worked well and operated for 190 hours. The gasifier operation was smooth, with the exception of the decrease in efficiency in the primary cyclone that caused the gasifier to slowly lose bed material.

Figure A.1-1 gives a summary of operating test hours achieved with the PSDF gasification process. 


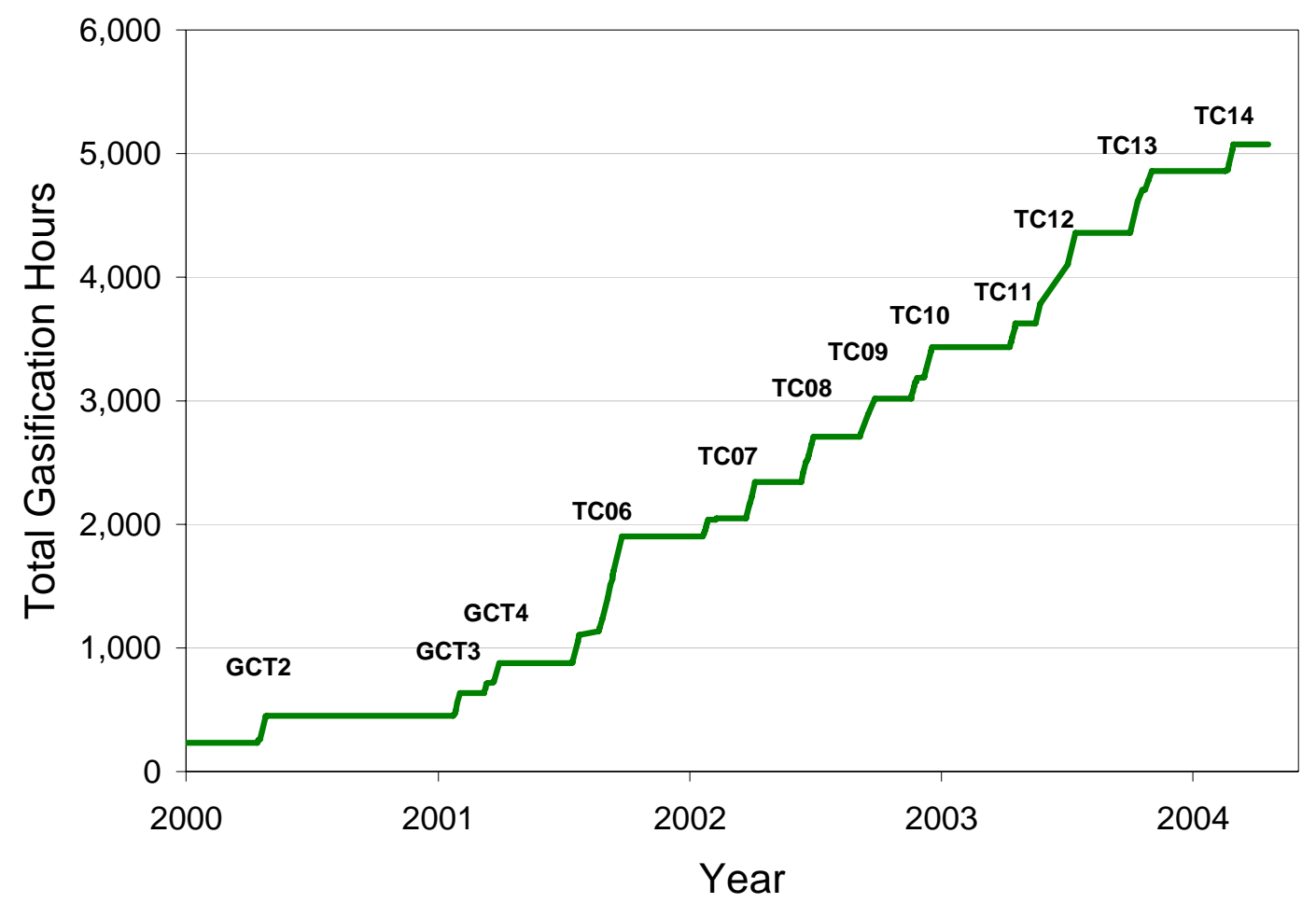

Figure A.1-1 Operating Hours Summary for the PSDF Gasification Process 


\section{APPENDIX A2 EQUIPMENT LIST}

Major Equipment in the Transport Gasifier Train

\begin{tabular}{|c|c|}
\hline TAG NAME & DESCRIPTION \\
\hline BR0201 & Gasifier Start-Up Burner \\
\hline BR0401 & Thermal Oxidizer \\
\hline BR0452 & Piloted Syngas Burner (PSB) \\
\hline BR0602 & AFBC Start-Up Burner \\
\hline C00201 & Main Air Compressor \\
\hline C00401 & Recycle Gas Booster Compressor \\
\hline C00451 & Turbine Air Compressor \\
\hline $\mathrm{C00601}$ & Sulfator Air Compressor \\
\hline CY0201 & Primary Cyclone in the Reactor Loop \\
\hline CYO207 & Disengager in the Reactor Loop \\
\hline CY0601 & AFBC Cyclone \\
\hline DR0402 & Steam Drum \\
\hline DY0201 & Feeder System Air Dryer \\
\hline FD0206 & Spent Solids Screw Cooler \\
\hline FD0210 & Coal Feeder System \\
\hline FD0220 & Sorbent Feeder System \\
\hline FD0502 & Fines Screw Cooler \\
\hline FD0510 & Spent Solids Transporter System \\
\hline FD0520 & Fines Transporter System \\
\hline FD0530 & Spent Solids Feeder System \\
\hline FD0540 & Continuous Fine Ash Depressurization (CFAD) System \\
\hline FD0602 & AFBC Solids Screw Cooler \\
\hline FD0610 & AFBC Sorbent Feeder System \\
\hline FL0301 & Particulate Control Device (PCD) \\
\hline FL0401 & Compressor Intake Filter \\
\hline GN0451 & Turbine Generator \\
\hline GT0451 & Gas Turbine \\
\hline HX0202 & Primary Gas Cooler \\
\hline $\mathrm{HX0203}$ & Combustor Heat Exchanger \\
\hline HX0204 & Transport Air Cooler \\
\hline HX0402 & Secondary Gas Cooler \\
\hline HX0405 & Compressor Feed Cooler \\
\hline HX0540 & CFAD Collection Drum/Heat Exchanger \\
\hline HX0601 & Sulfator Heat Recovery Exchanger \\
\hline ME0540 & Heat Transfer Fluid System \\
\hline RX0201 & Transport Gasifier \\
\hline SI0602 & Spent Solids Silo \\
\hline SU0601 & Atmospheric Fluidized Bed Combustor (AFBC) \\
\hline
\end{tabular}


Major Equipment in the Balance of Plant (Page 1 of 3)

\begin{tabular}{|l|l|}
\hline \multicolumn{1}{|c|}{ TAG NAME } & \\
\hline B02920 & Auxiliary Boiler \\
\hline B02921 & Auxiliary Boiler - Superheater \\
\hline CL2100 & Cooling Tower \\
\hline C02201A-D & Service Air Compressor A-D \\
\hline C02202 & Air-Cooled Service Air Compressor \\
\hline C02203 & High-Pressure Air Compressor \\
\hline C02601A-C & Reciprocating Nitrogen Compressor A-C \\
\hline CR0104 & Coal and Sorbent Crusher \\
\hline CV0100 & Crushed Feed Conveyor \\
\hline CV0101 & Crushed Material Conveyor \\
\hline DP2301 & Baghouse Bypass Damper \\
\hline DP2303 & Inlet Damper on Dilution Air Blower \\
\hline DP2304 & Outlet Damper on Dilution Air Blower \\
\hline DY2201A-D & Service Air Dryer A-D \\
\hline DY2202 & Air-Cooled Service Air Compressor Air Dryer \\
\hline DY2203 & High-Pressure Air Compressor Air Dryer \\
\hline FD0104 & MWK Coal Transport System \\
\hline FD0111 & MWK Coal Mill Feeder \\
\hline FD0113 & Sorbent Mill Feeder \\
\hline FD0140 & Coke Breeze and Bed Material Transport System \\
\hline FD0154 & MWK Limestone Transport System \\
\hline FD0810 & Ash Unloading System \\
\hline FD0820 & Baghouse Ash Transport System \\
\hline FL0700 & Baghouse \\
\hline FN0700 & Dilution Air Blower \\
\hline H00100 & Reclaim Hopper \\
\hline H00105 & Crushed Material Surge Hopper \\
\hline H00252 & Coal Surge Hopper \\
\hline H00253 & Sorbent Surge Hopper \\
\hline HT2101 & MWK Equipment Cooling Water Head Tank \\
\hline HT2103 & SCS Equipment Cooling Water Head Tank \\
\hline HT0399 & $60-$ Ton Bridge Crane \\
\hline HX2002 & MWK Steam Condenser \\
\hline HX2003 & MWK Feed Water Heater \\
\hline & \\
\hline
\end{tabular}


Major Equipment in the Balance of Plant (Page 2 of 3)

\begin{tabular}{|l|l|}
\hline \multicolumn{1}{|c|}{ TAG NAME } & \\
\hline HX2004 & MWK Subcooler \\
\hline HX2103A & SCS Cooling Water Heat Exchanger \\
\hline HX2103B & FW Cooling Water Heat Exchanger \\
\hline HX2103C & MWK Cooling Water Heat Exchanger \\
\hline LF0300 & Propane Vaporizer \\
\hline MC3001-3017 & MCCs for Various Equipment \\
\hline ME0700 & MWK Stack \\
\hline ME0814 & Dry Ash Unloader for MWK Train \\
\hline ML0111 & Coal Mill for MWK Train \\
\hline ML0113 & Sorbent Mill for Both Trains \\
\hline PG0011 & Oxygen Plant \\
\hline PG2600 & Nitrogen Plant \\
\hline PU2000A-B & MWK Feed Water Pump A-B \\
\hline PU2100A-B & Raw Water Pump A-B \\
\hline PU2101A-B & Service Water Pump A-B \\
\hline PU2102A-B & Cooling Tower Make-Up Pump A-B \\
\hline PU2103A-D & Circulating Water Pump A-D \\
\hline PU2107 & SCS Cooling Water Make-Up Pump \\
\hline PU2109A-B & SCS Cooling Water Pump A-B \\
\hline PU2110A-B & FW Cooling Water Pump A-B \\
\hline PU2111A-B & MWK Cooling Water Pump A-B \\
\hline PU2300 & Propane Pump \\
\hline PU2301 & Diesel Rolling Stock Pump \\
\hline PU2302 & Diesel Generator Transfer Pump \\
\hline PU2303 & Diesel Tank Sump Pump \\
\hline PU2400 & Fire Protection Jockey Pump \\
\hline PU2401 & Diesel Fire Water Pump \#1 \\
\hline PU2402 & Diesel Fire Water Pump \#2 \\
\hline PU2504A-B & Waste Water Sump Pump A-B \\
\hline PU2507 & Coal and Limestone Storage Sump Pump \\
\hline PU2700A-B & Demineralizer Forwarding Pump A-B \\
\hline
\end{tabular}


Major Equipment in the Balance of Plant (Page 3 of 3)

\begin{tabular}{|l|l|}
\hline \multicolumn{1}{|c|}{ TAG NAME } & \multicolumn{1}{c|}{ DESCRIPTION } \\
\hline PU2920A-B & Auxiliary Boiler Feed Water Pump A-B \\
\hline SB3001 & 125-V DC Station Battery \\
\hline SB3002 & UPS \\
\hline SC0700 & Baghouse Screw Conveyor \\
\hline SG3000-3005 & 4160-V, 480-V Switchgear Buses \\
\hline SI0101 & MWK Crushed Coal Storage Silo \\
\hline SI0103 & Crushed Sorbent Storage Silo \\
\hline SI0111 & MWK Pulverized Coal Storage Silo \\
\hline SI0113 & MWK Limestone Silo \\
\hline SI0114 & FW Limestone Silo \\
\hline SI0810 & Ash Silo \\
\hline ST2601 & Nitrogen Storage Tube Bank \\
\hline TK2000 & MWK Condensate Storage Tank \\
\hline TK2001 & FW Condensate Tank \\
\hline TK2100 & Raw Water Storage Tank \\
\hline TK2300A-D & Propane Storage Tank A-D \\
\hline TK2301 & Diesel Storage Tank \\
\hline TK2401 & Fire Water Tank \\
\hline XF3000A & 230/4.16-kV Main Power Transformer \\
\hline XF3001B-5B & 4160/480-V Station Service Transformer No. 1-5 \\
\hline XF3001G & 480/120-V Miscellaneous Transformer \\
\hline XF3010G & 120/208 Distribution Transformer \\
\hline XF3012G & UPS Isolation Transformer \\
\hline VS2203 & High-Pressure Air Receiver \\
\hline
\end{tabular}




\section{APPENDIX A3 MASS AND ENERGY BALANCES}

Material balances are useful in checking the accuracy and consistency of data as well as determining periods of operation where the data is suitable for model development or commercial plant design. Total material balances for each operating period are given in Figure A.3-1 which compare the total mass in and the total mass out. The overall material balance was good, with all of the relative differences at \pm 10 percent. The relative difference (relative error) is defined as the Transport Gasifier feeds minus the products divided by the feeds ( $\{$ In-Out $\} /$ In). All of the air blown operating periods had higher overall mass flow rates than the oxygen-blown operating periods due to additional nitrogen from air fed to the Transport Gasifier.

The main contributors to the material balance are the syngas flow rate $(13,100$ to 21,000 $\mathrm{pph}$ ), the air flow rate (300 to $12,000 \mathrm{pph}$ ), the oxygen flow rate (0 to 1,700 pph), the steam flow rate (500 to 2,000 pounds per hour), the nitrogen flow rate (5,700 to 7,100 pph), and the coal feed rate $(2,000$ to $4,400 \mathrm{pph})$. Although higher than in previous test runs, the sand feed rate ( 0 to $400 \mathrm{pph}$ ) contributed only a small amount to the overall mass balance.

The TC14 Transport Gasifier energy balance is shown in Figure A.3-2 with standard conditions chosen to be 1.0 atmosphere pressure and $80^{\circ} \mathrm{F}$ temperature. As shown in the figure, the TC14 energy balances were within \pm 13 percent error. The energy entering the gasifier consisted of the coal, air, and steam fed to the Transport Gasifier. The nitrogen, oxygen and sand fed to the gasifier were considered to be at standard conditions and, hence, had zero enthalpy. The nitrogen and oxygen feeds actually entered the gasifier at a higher temperature than standard conditions, but compared to the other feed enthalpies, this neglected input energy is insignificant. Since the standpipe solids removal system did not operate during the TC14 operating periods, the energy exiting the gasifier consisted of only the syngas and PCD solids. The analysis used the lower heating value of the coal, the PCD solids, and the syngas rather than the higher heating value.

The energy of the syngas was determined at the Transport Gasifier cyclone exit. About 1,200 pounds $\mathrm{N}_{2}$ per hour flowed to the PCD inlet and outlet particulate sampling trains. This nitrogen was subtracted from the exit flow rate to determine the actual syngas rate from the cyclone. The sensible enthalpy of the syngas was determined by the overall gas heat capacity from the syngas compositions and using gas heat capacities information. The syngas and PCD solids energy consists of both latent and sensible heat. The heat loss from the Transport Gasifier was estimated to be 3.5 million Btu/hr. 


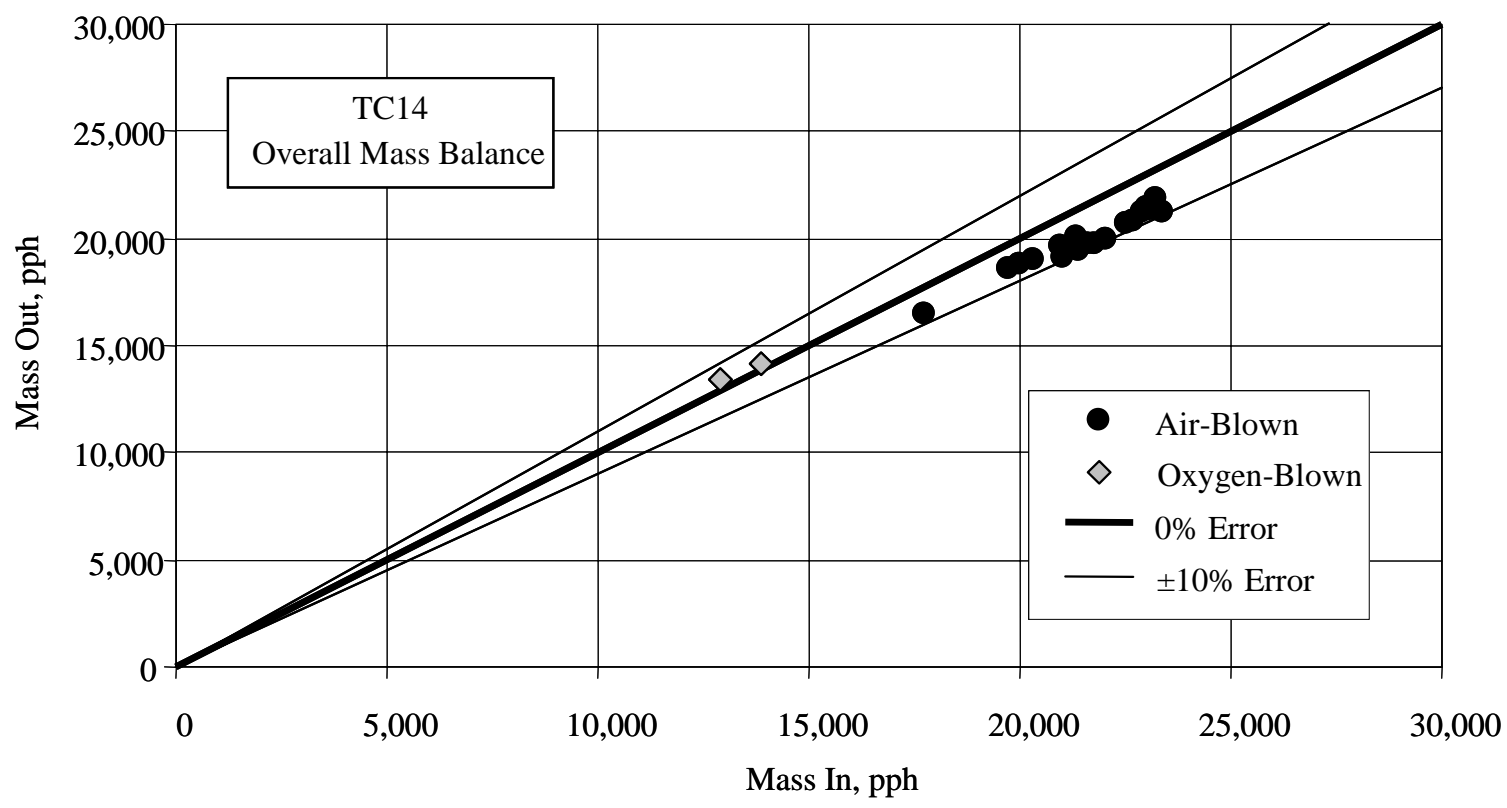

Figure A.3-1 Mass Balance

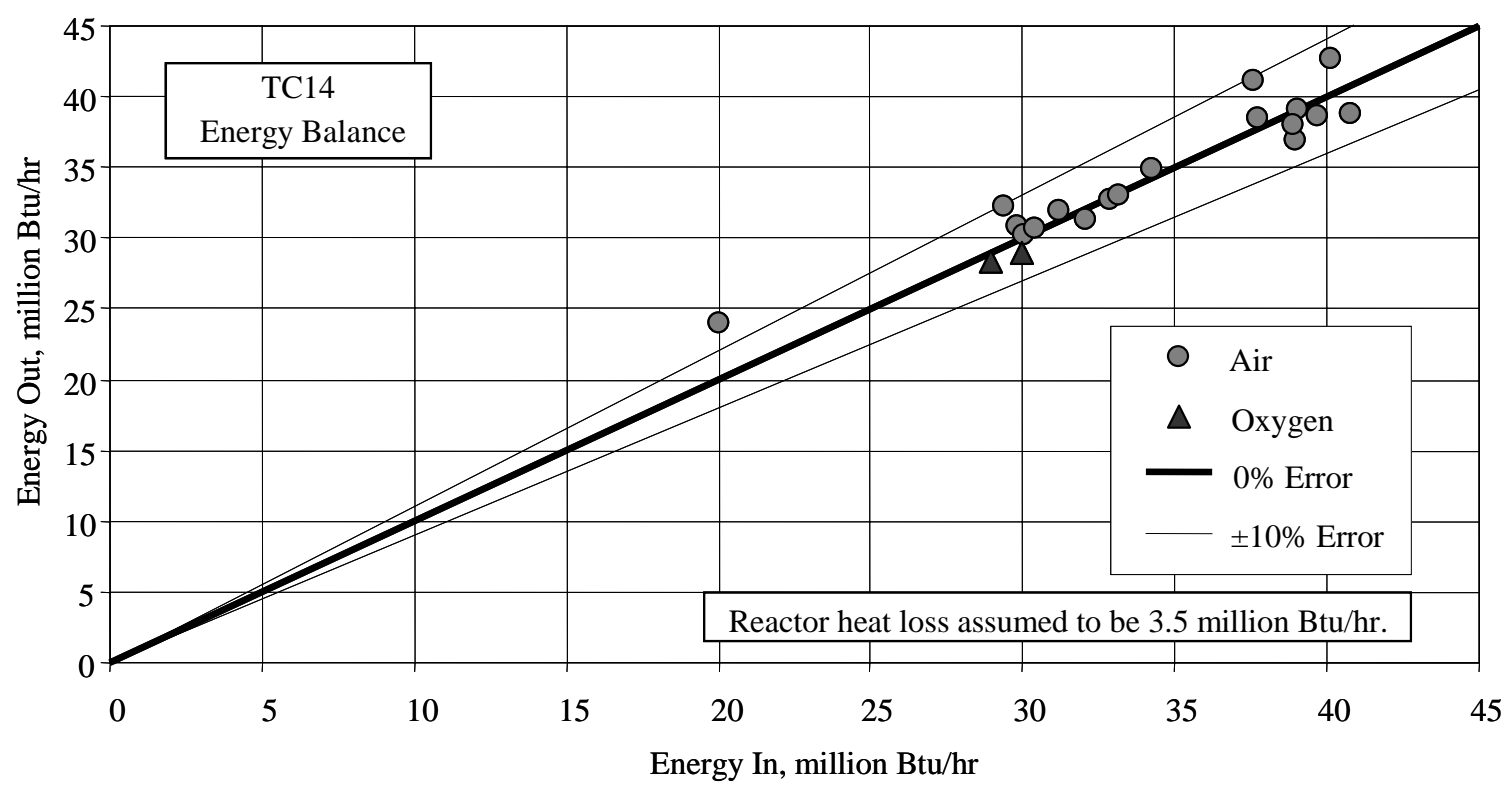

Figure A.3-2 Energy Balance 


\section{APPENDIX A4 OPERATING TRENDS}

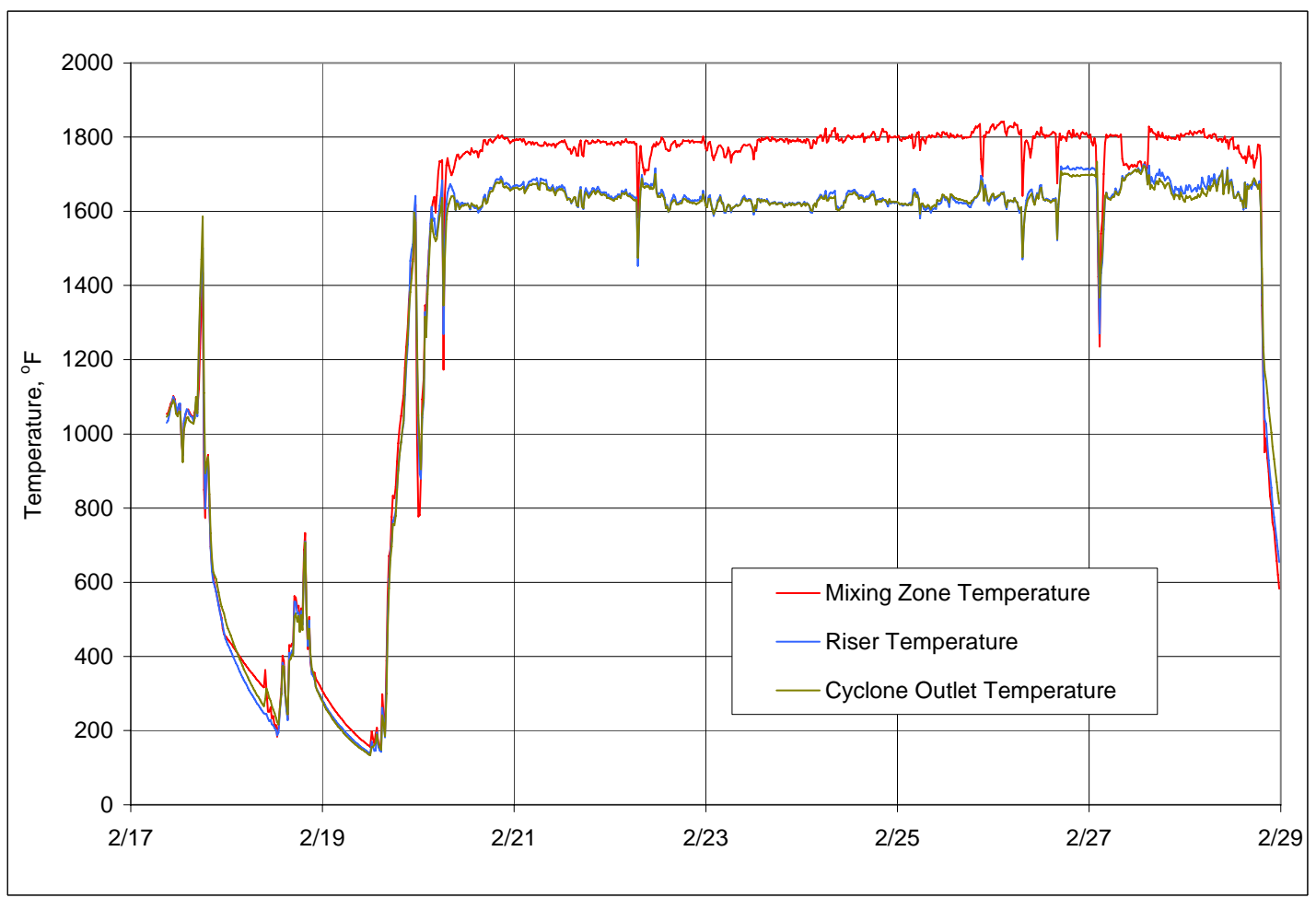

Figure A4-1 Gasifier Mixing Zone, Riser, and Outlet Temperatures

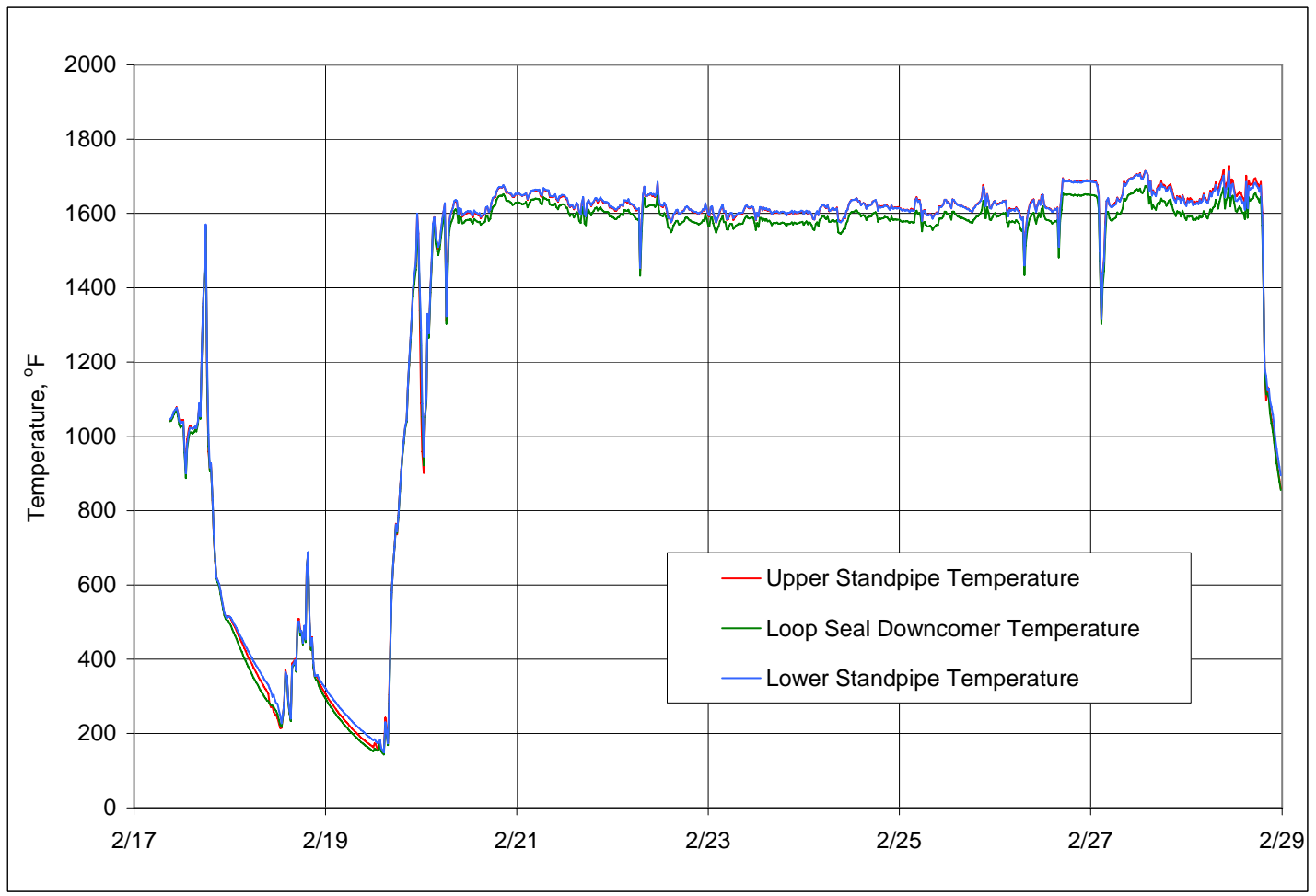

Figure A4-2 Standpipe and Loop Seal Temperatures 


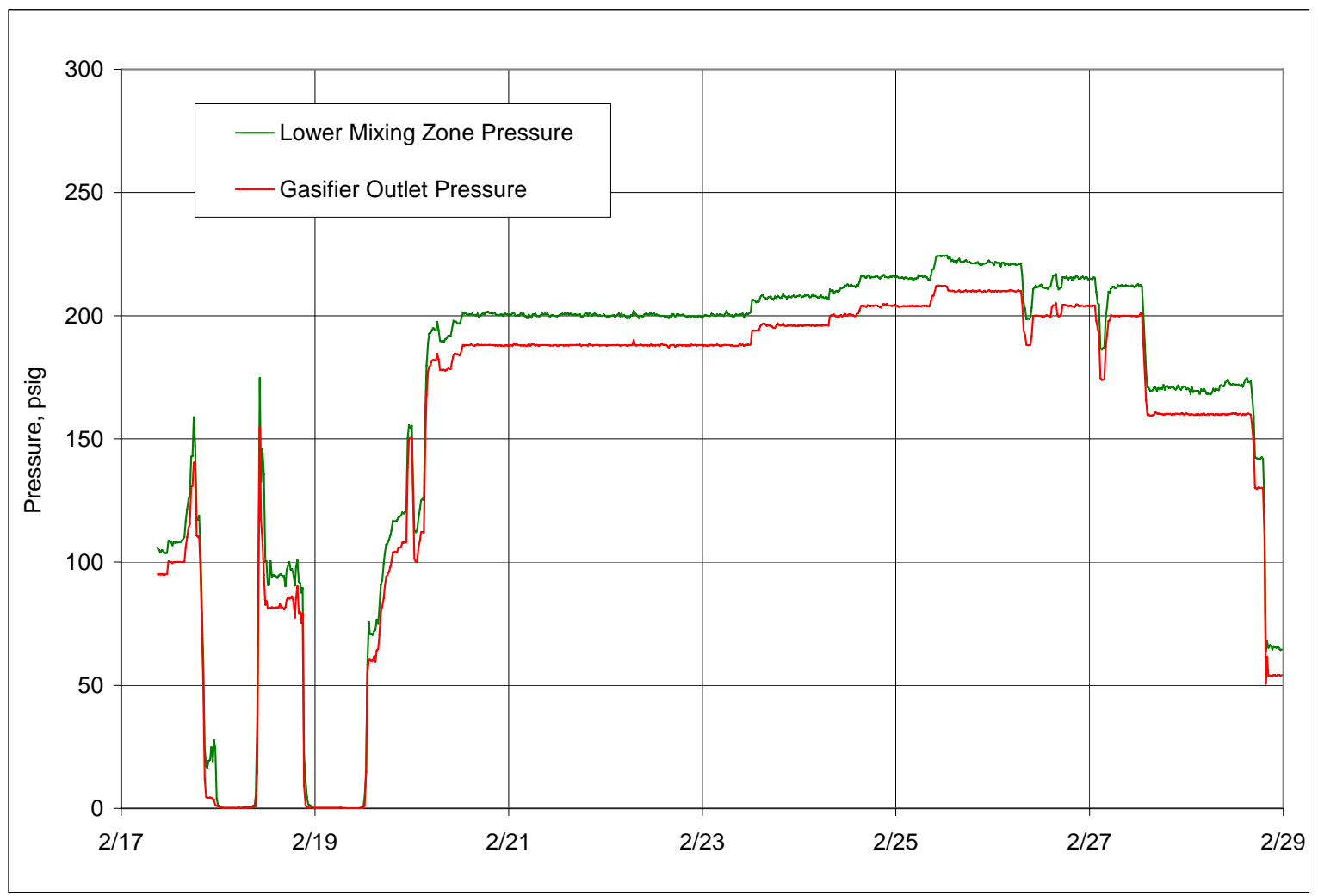

Figure A4-3 Gasifier Pressures

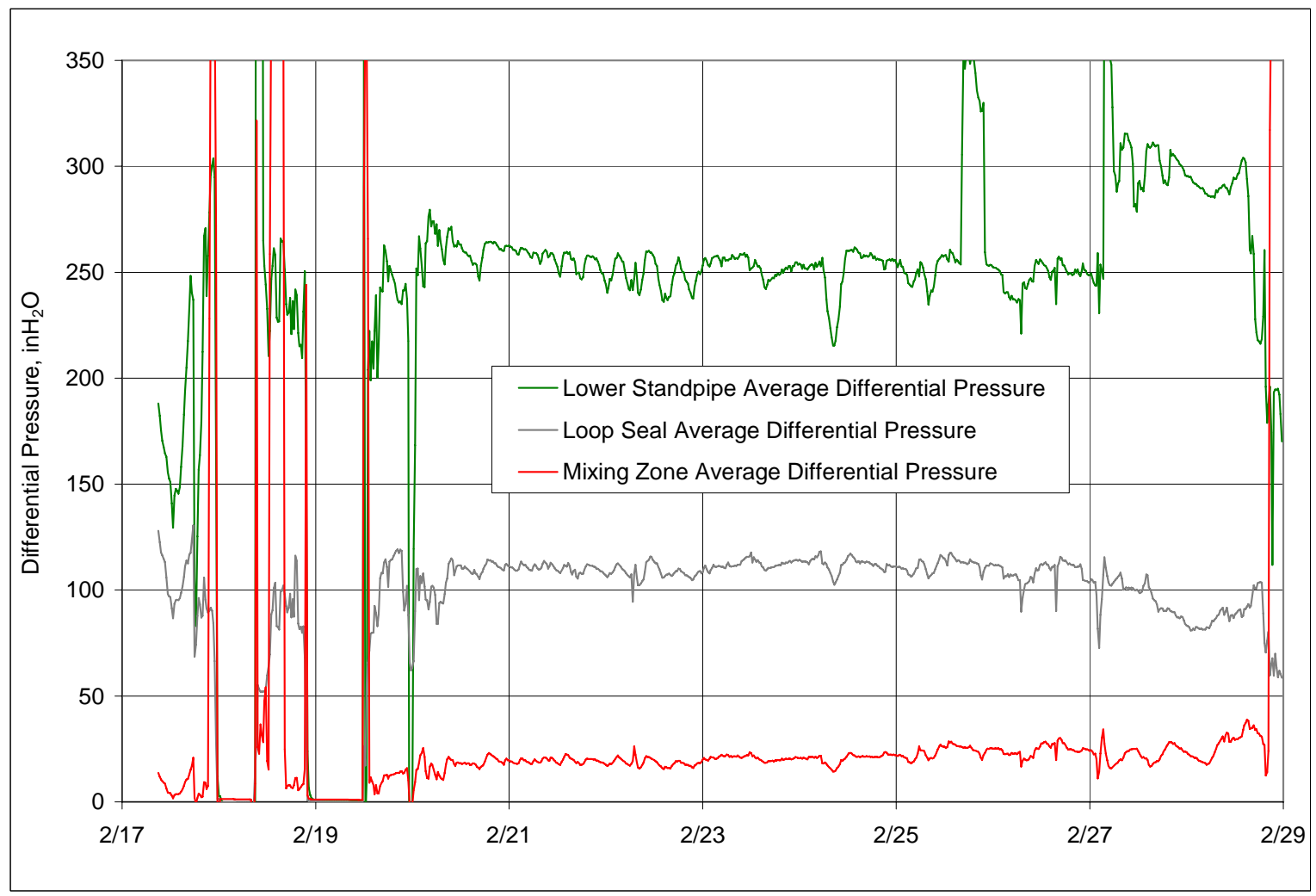

Figure A4-4 Gasifier Differential Pressures 


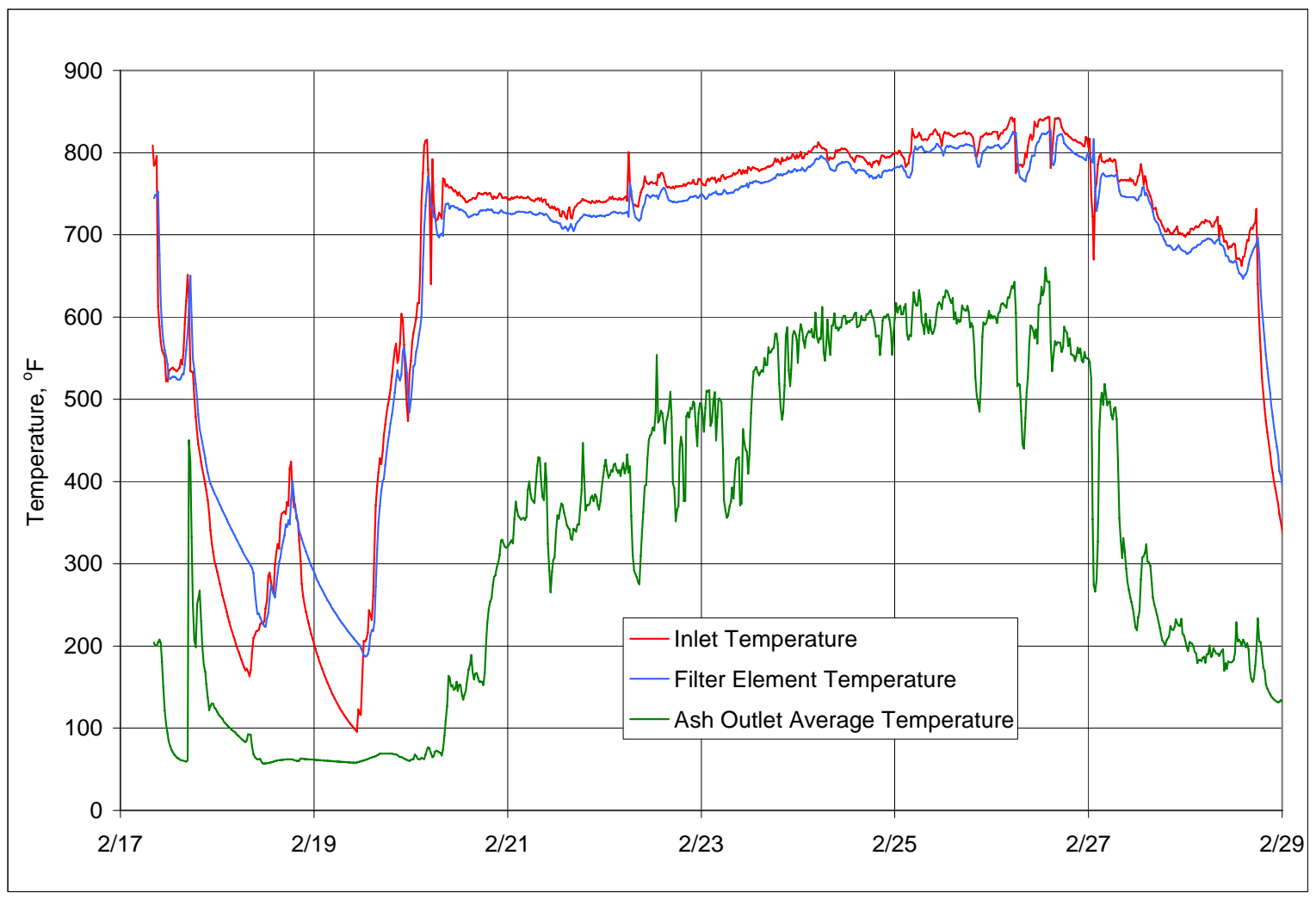

Figure A4-5 PCD Temperatures

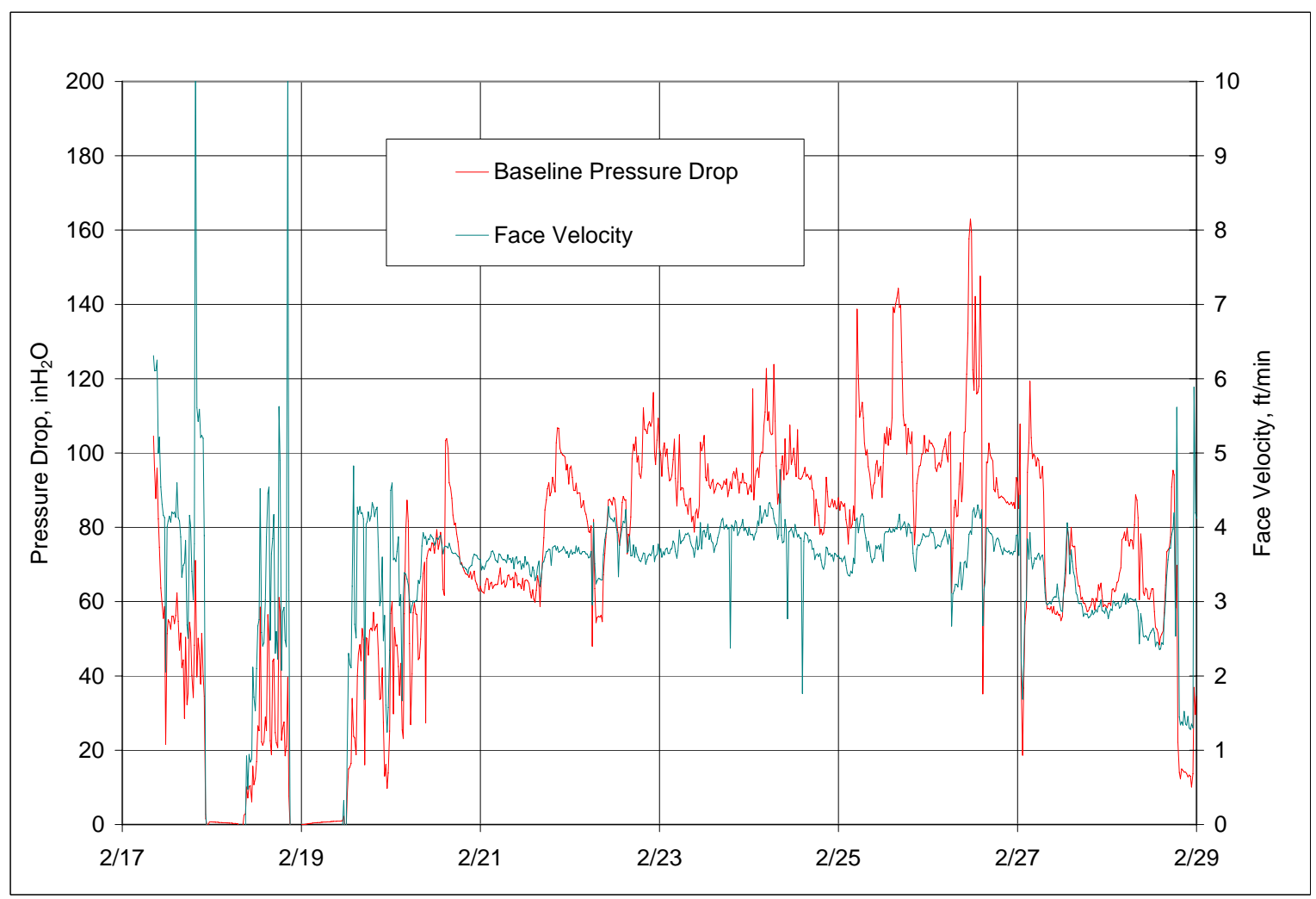

Figure A4-6 PCD Baseline Pressure Drop and Face Velocity 


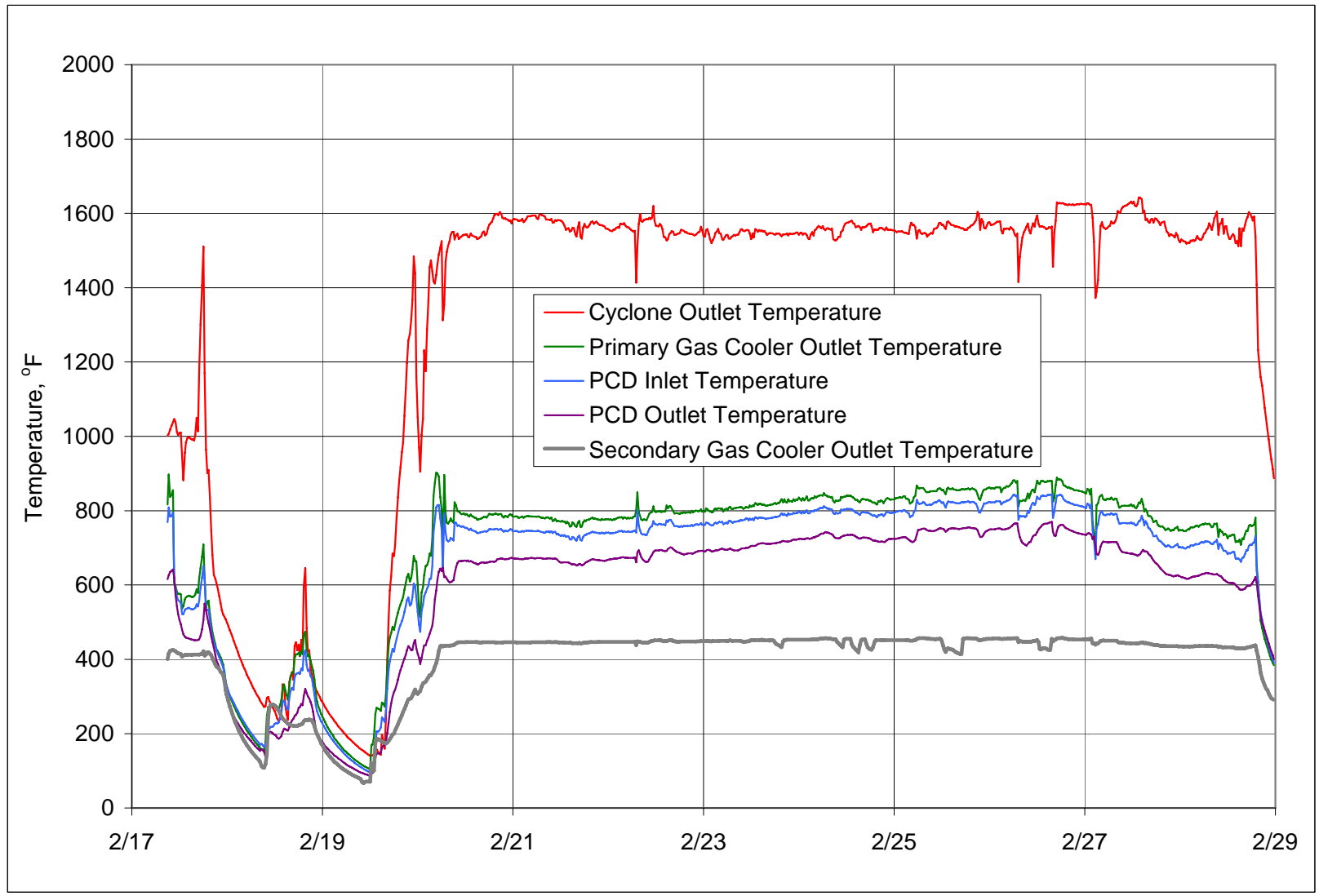

Figure A4-7 System Temperature Profile

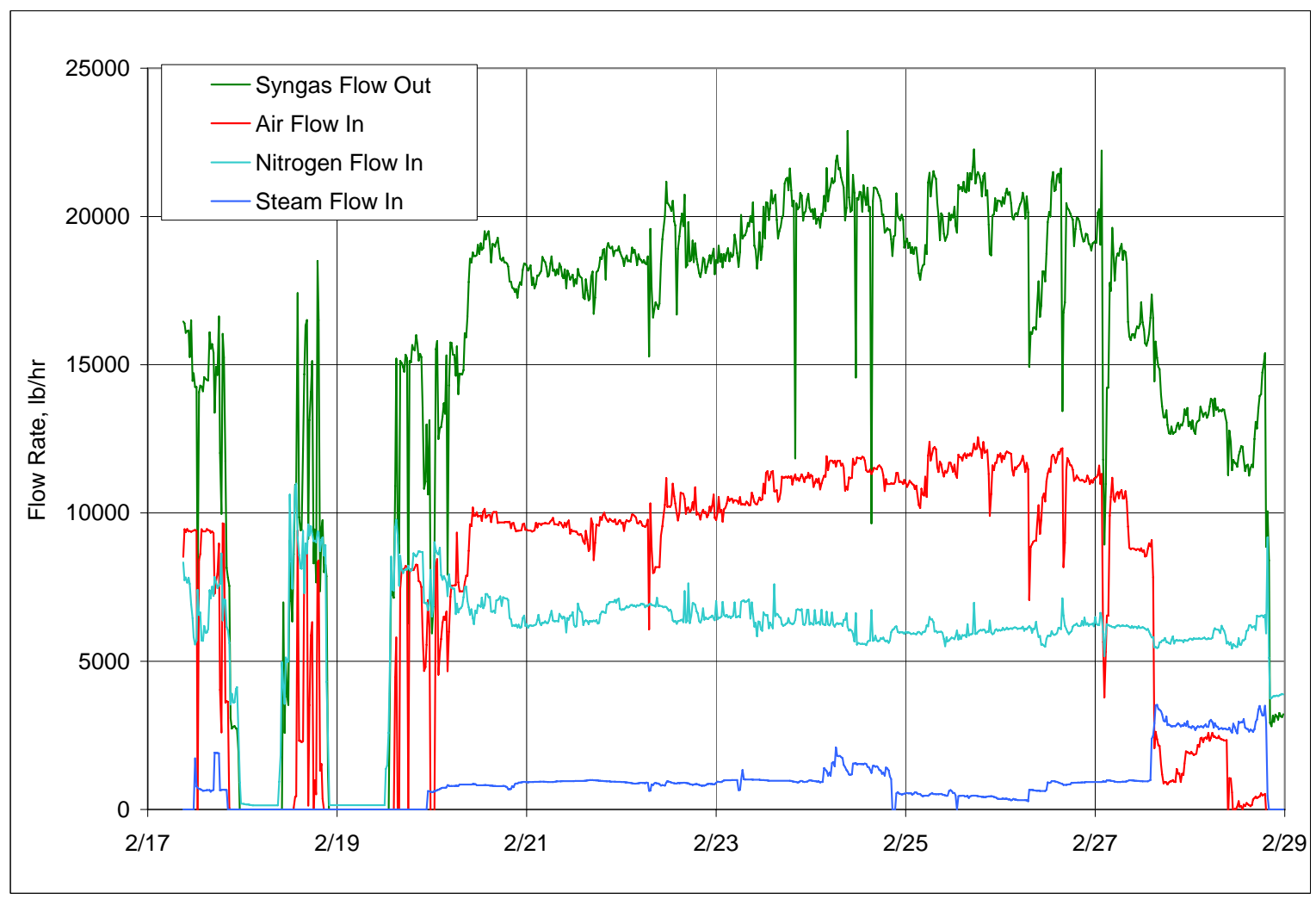

Figure A4-8 System Gas Flows 


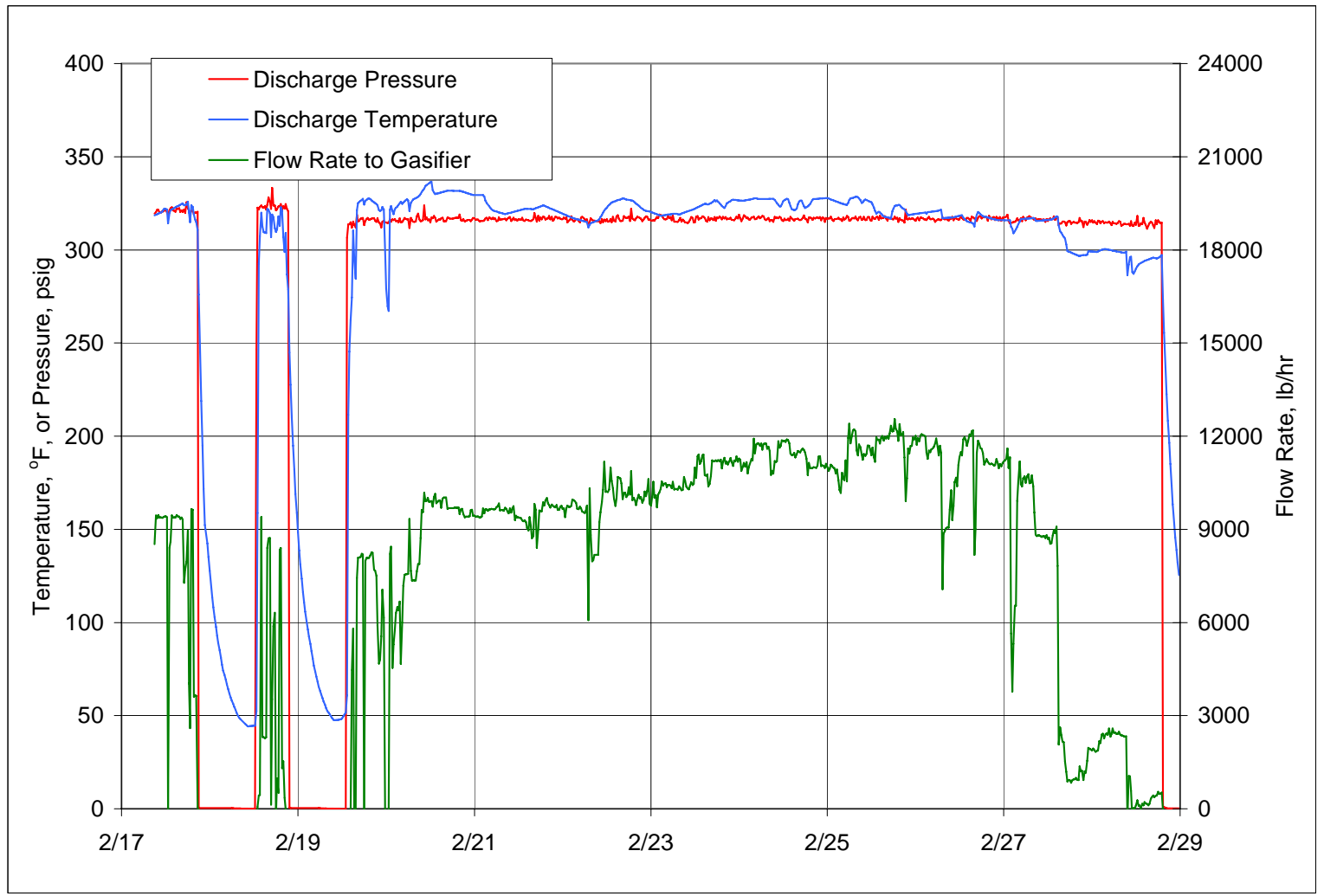

Figure A4-9 Main Air Compressor Operation

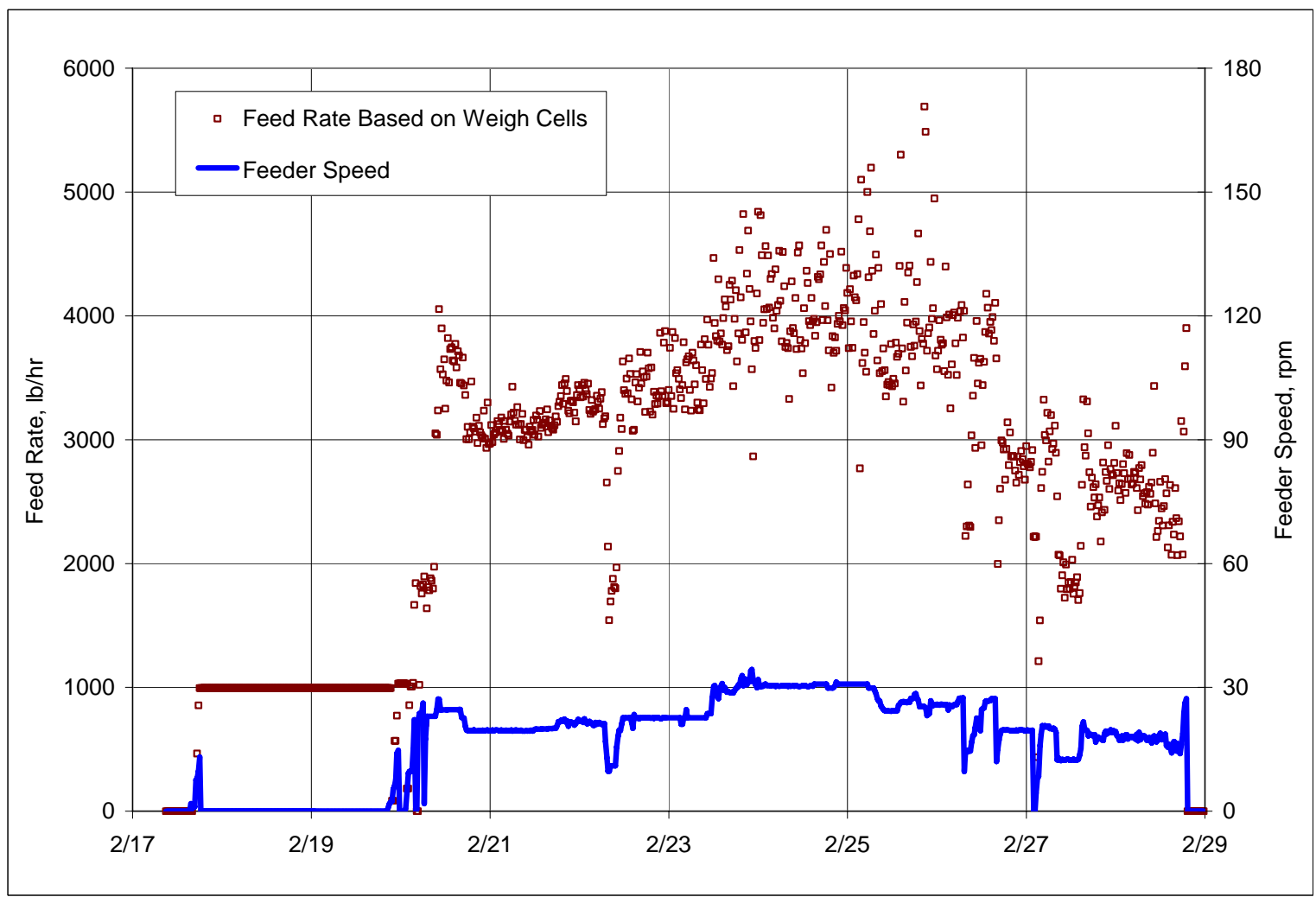

Figure A4-10 Original Coal Feeder Operation 


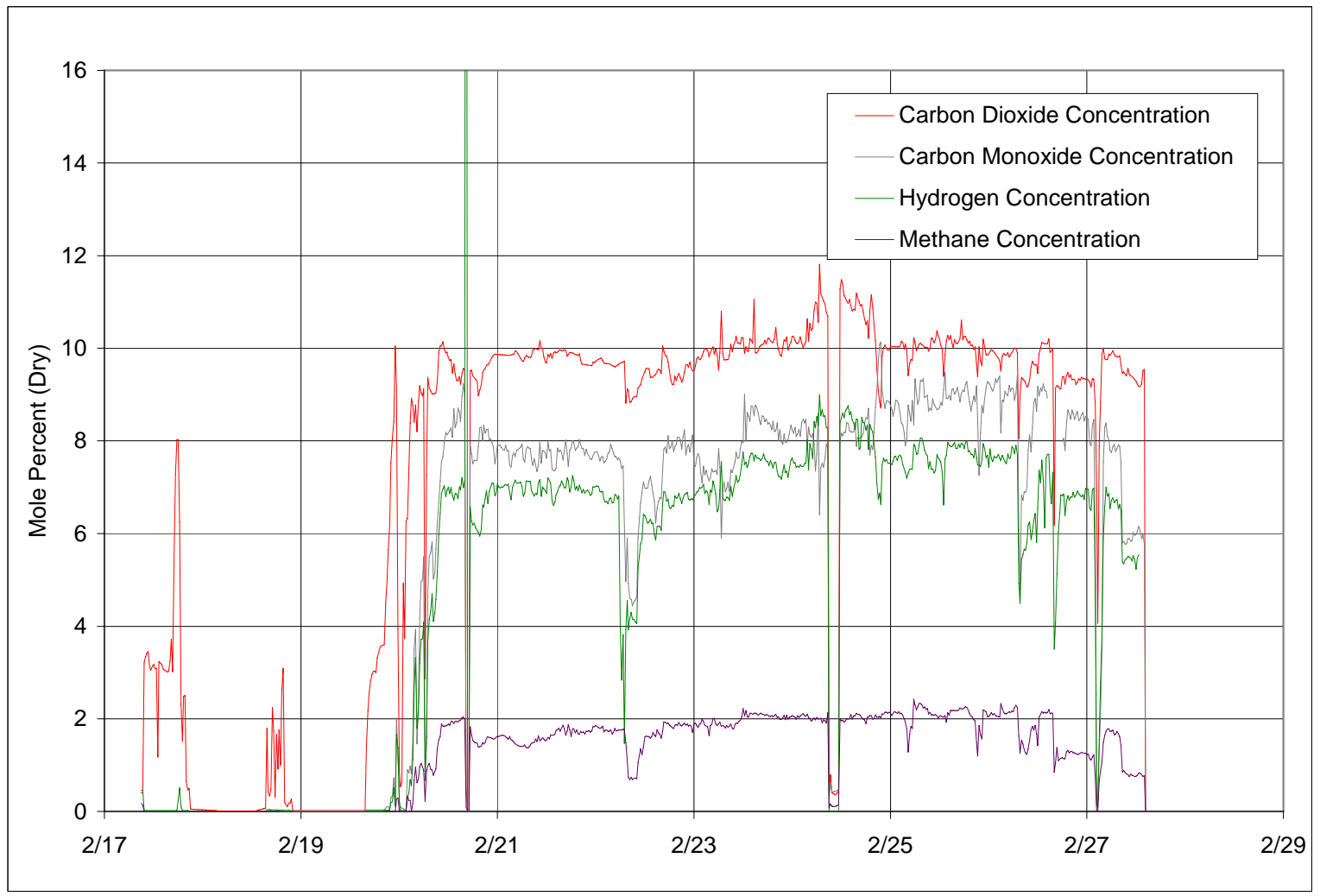

Figure A4-11 Syngas Analyzers

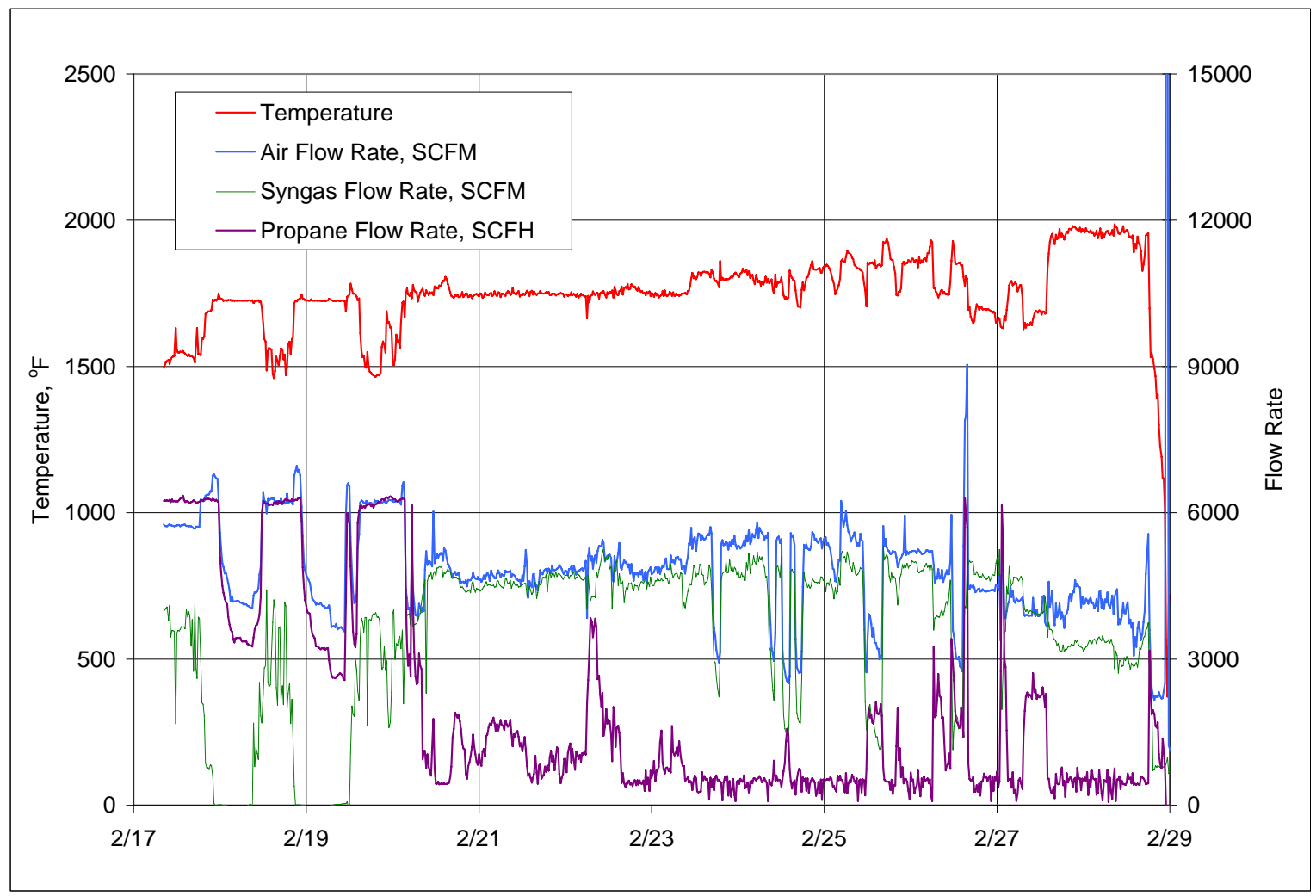

Figure A4-12 Atmospheric Syngas Combustor Operation 


\section{APPENDIX A5 LHV PROJECTION CALCULATIONS}

To project a commercial syngas LHV, the following adjustments are made to the raw syngas composition:

1. All non-air nitrogen is removed from the syngas. A commercial plant will have substantially less instrumentation than the PSDF. Because each individual instrument in a commercial plant will require the same purge flow rate as the corresponding instrument at the PSDF, the total instrument purge flow rate will be less. It is assumed that recycled syngas will be used in a commercial plant for aeration. This correction has the effect of increasing all the non-nitrogen syngas compositions and decreasing the nitrogen syngas composition. The recycle syngas flow enters the compressor after the "cold" gas cleanup system and is reheated before being used. Since the total amount of nitrogen entering the system is reduced, less coal energy will be required to heat the nitrogen, and the coal and air/oxygen feed rates will decrease accordingly. It is assumed that this coal would have been combusted to $\mathrm{CO}_{2}$ and $\mathrm{H}_{2} \mathrm{O}$. Eliminating this additional coal reduces the syngas $\mathrm{CO}_{2}$ and $\mathrm{H}_{2} \mathrm{O}$ concentrations. The lower projected air rates for air blown mode also decrease the nitrogen content in the projected syngas, and thus decreases the syngas flow rate. The $\mathrm{CO} / \mathrm{CO}_{2}$ ratio will change due to the reduction in $\mathrm{CO}_{2}$. This calculation requires an estimated recycle gas flow rate and an estimated steam aeration rate to determine the heat required to heat the recycle gas to system temperature. The recycle gas flow rate is estimated to be 2.4 percent of the syngas flow rate from the gasifier and is available at $235^{\circ} \mathrm{F}$. The aeration steam flow rate is estimated to be 1.45 percent of the syngas flow rate from the gasifier and available at $660^{\circ} \mathrm{F}$.

2. Small-scale pilot and demonstration units, such as the PSDF, have higher surface area to volume ratios than their scaled up commercial counterparts. Since the heat loss of a commercial plant is difficult to estimate, the projected heat loss is assumed to be zero (adiabatic). The coal, air, and oxygen rates are reduced; the syngas $\mathrm{CO}_{2}$, $\mathrm{H}_{2} \mathrm{O}$, and $\mathrm{N}_{2}$ concentrations are reduced; the $\mathrm{CO} / \mathrm{CO}_{2}$ ratio change. Based on energy balance data, the heat loss for the PSDF Transport gasifier is approximately 3.5 million Btu/hr.

3. The steam flow rate is adjusted. The steam to oxygen ratio will be the same for the PSDF and the commercial Transport Gasifier. Since Steps 1 and 2 reduce the amount of oxygen required, the steam flow rate will decrease correspondingly. The effect of lowering the steam rate will decrease the amount of $\mathrm{H}_{2} \mathrm{O}$ in the syngas by the amount the steam rate was reduced. The steam rate and the $\mathrm{H}_{2} \mathrm{O}$ content of the syngas are reduced, and hence, the LHV also changes.

4. The water gas shift is recalculated to reflect the gasifier exit temperature. Corrections $\# 1$, \#2, and \#3 change the water gas shift equilibrium constant without affecting the gasifier exit temperature. The commercial plant will operate at the same gasifier exit temperature as the PSDF and hence have the same water gas shift equilibrium constant. The $\mathrm{H}_{2} \mathrm{O}, \mathrm{CO}_{2}, \mathrm{CO}$, and $\mathrm{H}_{2}$ concentrations are then adjusted based on the water gas shift equilibrium for the temperature of that particular operating period. The LHV could increase if $\mathrm{H}_{2}$ and $\mathrm{CO}_{2}$ are converted to $\mathrm{H}_{2} \mathrm{O}$ and $\mathrm{CO}$, since the 
LHV for $\mathrm{CO}$ is higher than for $\mathrm{H}_{2}$. The LHV will decrease if $\mathrm{H}_{2} \mathrm{O}$ and $\mathrm{CO}$ are converted to $\mathrm{H}_{2}$ and $\mathrm{CO}_{2}$. The LHV correction is usually small, but the change in composition is important if the syngas is used in a fuel cell or for chemical production where the $\mathrm{H}_{2}$ concentration is a critical design parameter.

5. The commercial plant will use a cold syngas cleanup train that will drop the syngas temperature to $150^{\circ} \mathrm{F}$, before being reheated prior to entering the gas turbine. At these conditions moisture will condense from the syngas and exit via a liquid stream. For the commercial design at 388 psia, the syngas water composition at the gas turbine inlet is 0.96 percent. Thus, the final step reduces the syngas moisture content to this value and adjusts the other contents accordingly.

The result of all of these corrections is the commercially projected LHV. Changes \#1 and \#2 both increase the oxygen blown LHV more than for the air blown LHV because 100 percent of the syngas nitrogen is removed in the oxygen blown projection, while only about 50 percent of the syngas nitrogen is removed for the air blown projection.

These calculations are an oversimplification of the gasification process. A more sophisticated model is required to precisely predict the effects of decreasing pure nitrogen and gasifier heat loss. Note that the projected syngas compositions are based on a projected coal rate, projected air rate, projected oxygen rate, projected steam rate, and a projected syngas rate. 